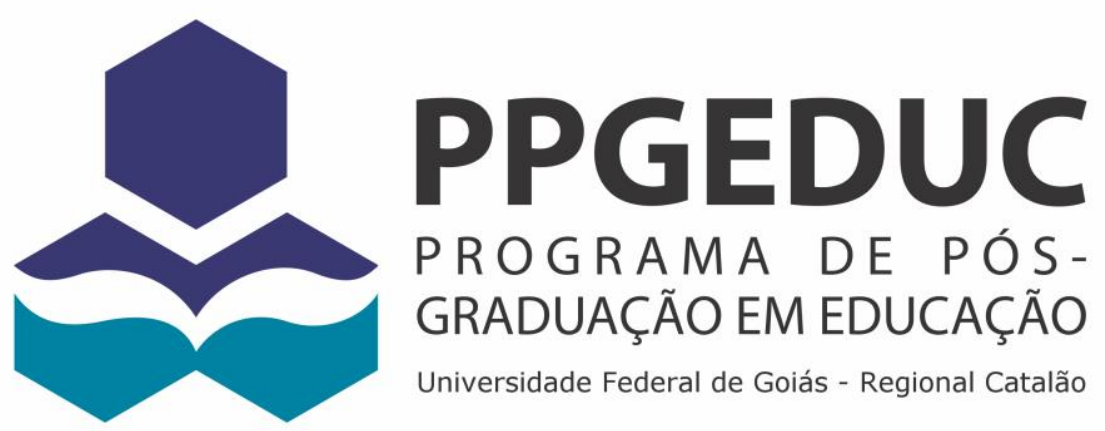

\title{
FORMAÇÃO E (RE) SOCIALIZAÇÃO DE ADOLESCENTES EM PRIVAÇÃO DE LIBERDADE: práticas e políticas educacionais no Centro Socioeducativo de Unaí - CSEUN
}

FABIANO ELIAS NUNES

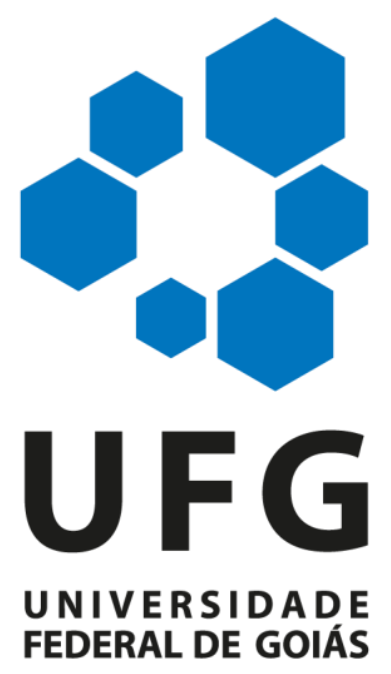




\section{TERMO DE CIÊNCIA E DE AUTORIZAÇÃO PARA DISPONIBILIZAR VERSÕES ELETRÔNICAS DE TESES E DISSERTAÇÕES NA BIBLIOTECA DIGITAL DA UFG}

Na qualidade de titular dos direitos de autor, autorizo a Universidade Federal de Goiás (UFG) a disponibilizar, gratuitamente, por meio da Biblioteca Digital de Teses e Dissertações (BDTD/UFG), regulamentada pela Resolução CEPEC $n^{\circ}$ 832/2007, sem ressarcimento dos direitos autorais, de acordo com a Lei $\mathrm{n}^{\circ}$ 9610/98, o documento conforme permissões assinaladas abaixo, para fins de leitura, impressão e/ou download, a título de divulgação da produção científica brasileira, a partir desta data.

\section{Identificação do material bibliográfico: [ x ] Dissertação [ ] Tese}

\section{Identificação da Tese ou Dissertação:}

Nome completo do autor: Fabiano Elias Nunes

Título do trabalho: Formação e (re) socialização de adolescentes em privação de liberdade: práticas e políticas educacionais no centro socioeducativo de Unaí - CSEUN.

\section{Informações de acesso ao documento:}

Concorda com a liberação total do documento [ $\mathrm{x}$ ] SIM

Havendo concordância com a disponibilização eletrônica, torna-se imprescindível o envio do(s) arquivo(s) em formato digital PDF da tese ou dissertação.

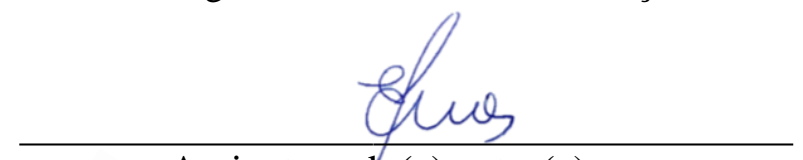

Assinatura do(a) autor(a)

Ciente e de acordo:

Assinatura do(a) orientador(a) ${ }^{2}$

Data: $27 / 03 / 2018$ 


\section{FABIANO ELIAS NUNES}

\section{FORMAÇÃO E (RE) SOCIALIZAÇÃO DE ADOLESCENTES EM PRIVAÇÃ̃ DE LIBERDADE: práticas e políticas educacionais no Centro Socioeducativo de Unaí - CSEUN}

Dissertação de Mestrado apresentada como requisito parcial para a obtenção de título de Mestre em Educação à comissão examinadora do Programa de Pós-Graduação em Educação da Universidade Federal de Goiás - Regional Catalão.

Orientador: Prof. Dr. Wender Faleiro

Linha de Pesquisa: Leitura, Educação e Ensino de Língua Materna e Ciências da Natureza

Catalão - GO 
Ficha de identificação da obra elaborada pelo autor, através do Programa de Geração Automática do Sistema de Bibliotecas da UFG.

NUNES, FABIANO ELIAS

Formação e (re) socialização de adolescentes em privação de liberdade: práticas e políticas educacionais no centro socioeducativo de Unaí - CSEUN. [manuscrito] / FABIANO ELIAS NUNES. - 2018.

f.: il.

Orientador: Prof. Dr. Wender Faleiro.

Dissertação (Mestrado) - Universidade Federal de Goiás, Unidade Acadêmica Especial de Educação, Programa de Pós-Graduação em Educação, Catalão, 2018.

Bibliografia. Anexos. Apêndice.

Inclui siglas, mapas, abreviaturas, tabelas, lista de figuras, lista de tabelas.

1. Formação. 2. (Re)socialização. 3. Adolescente. 4. Medidas Socioeducativas. I. Faleiro, Wender, orient. II. Título. 


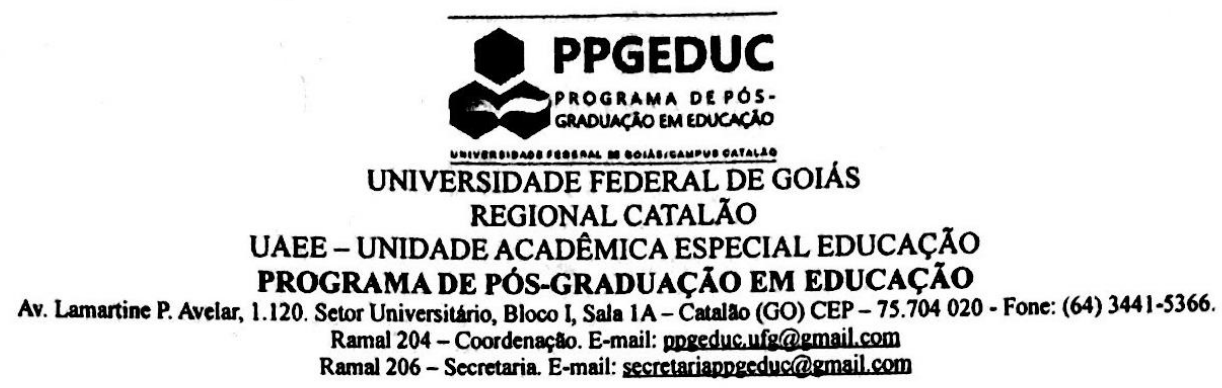

\section{ATA DA SESSÃO PÚBLICA DE JULGAMENTO DA DEFESA DE DISSERTAÇÃO DE FABIANO ELIAS NUNES}

\section{ATA DA COMISSÅO EXAMINADORADESIGNADA PELA COORDENADORIADO PPGEDUC PARA JULGAMENTO DA DEFESA DE DISSERTAÇÃO DE MESTRADO EM EDUCAÇÃO DE FABIANO ELIAS NUNES}

Em 28/02/2018, às 15:00, no Laboratório de Multimeios, da UFG/Regional Catalăo, teve lugar a Sessão Pública de Defesa de Dissertação do Mestrado em Educação da UFG/Regional Catalăo, de Fabiano Elias Nunes, intitulada: "FORMAÇÃO E (RE) SOCIALIZAÇÃO DE ADOLESCENTES EM PRIVAÇÃO DE LIBERDADE: práticas e políticas educacionais no Centro Socioeducativo de Unai - CSEUN". A Banca Examinadora foi composta, pelos seguintes professores: Wender Faleiro da Silva (PPGEDUC/UFG - Orientaçăo e Presidente da Banca), Lázara Cristina da Silva (UFU/PPGED - Membro Externo) e Cláudia Tavares do Amaral (PPGEDUC/UFG - Membro Interno). Os examinadores, na ordem citada, arguiram sobre a dissertaçăo apresentada, tendo a/o discente explicado e/ou rebatido as críticas formuladas pelos arguidores. Após a conclusão da defesa, foi suspensa a Sessão Pública e, em Sessão Secreta, os arguidores atribuiram seus conceitos. Reaberta a Sessão Pública, fo anunciado o resultado: DEFESA APROVADA, fazendo jus, portanto, ao título de Mestre em Educação, de acordo com o artigo 57 do Regulamento do Programa de Pós-Graduação em Educaçăo/Regional Catalão. Nada mais havendo a registrar, foi lavrada a presente ata, que vai assinada pelos Membros da Comissão Examinadora. Programa de Pós-Graduação em Educaçăo da UFG/Regional Catalăo.
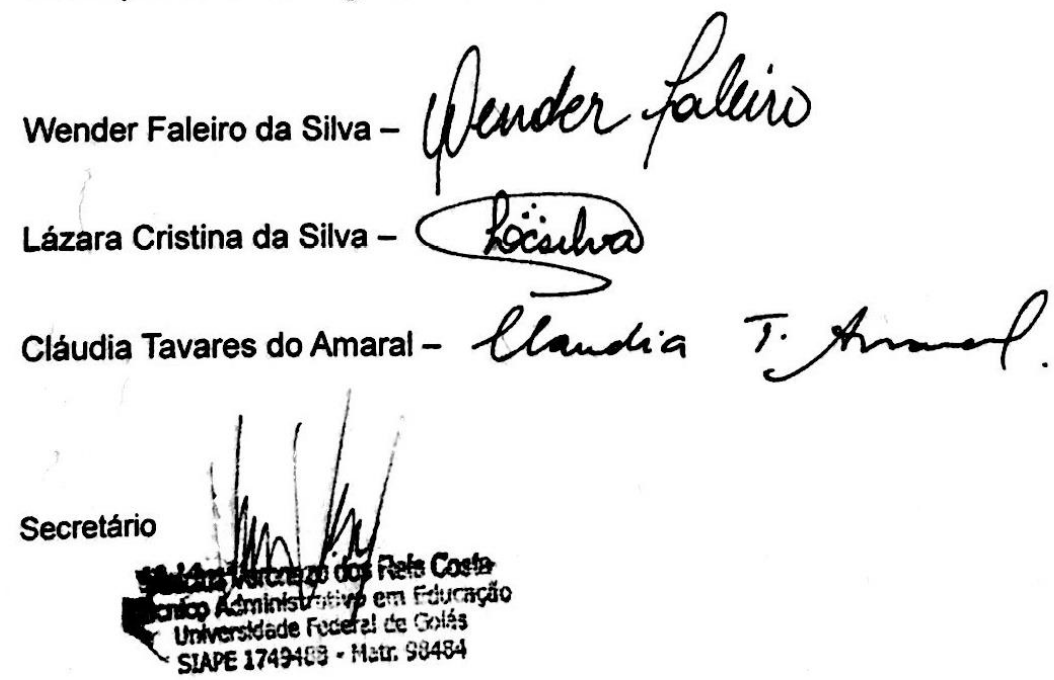


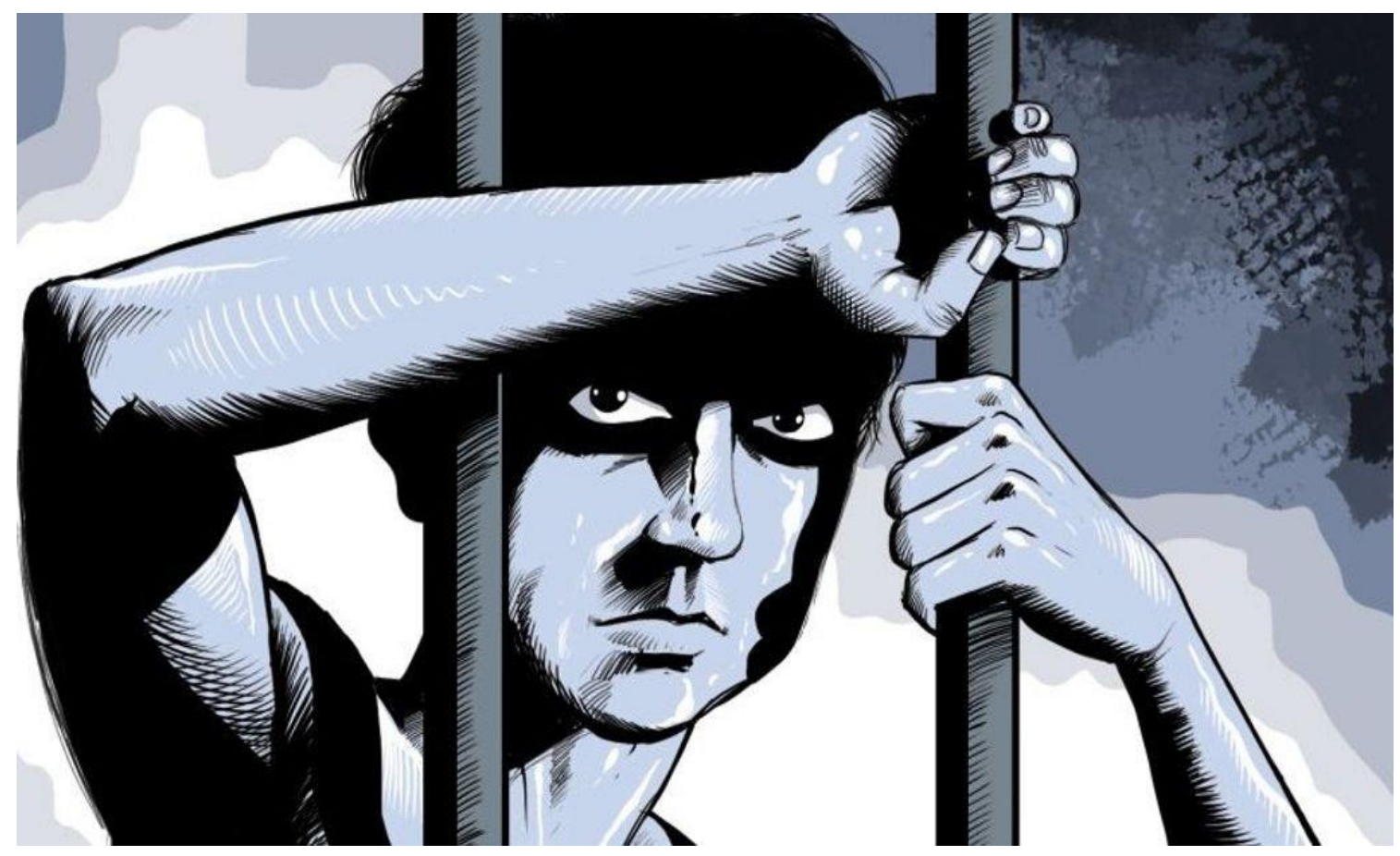

Foto: Gilberto Yamamoto /Arquivo Gazeta do Povo Disponível em: http://www.gazetadopovo.com.br/

"A prática da liberdade só encontrará adequada expressão numa pedagogia em que o oprimido tenha condições de, reflexivamente, descobrir-se e conquistar-se como sujeito de sua própria destinação histórica”.

(FIORI, 1992, p. 52). 


\section{AGRADECIMENTOS}

Pelas contribuições que, direta e indiretamente, me fizeram chegar ao fim desta pesquisa, agradeço:

Aos meus pais, Walquiria e José Antônio e todos os meus familiares que torceram desde o início e a cada etapa conquistada. Acompanharam as aflições, os anseios e foram compreensíveis no período de afastamento em que a prioridade do meu tempo foi para este trabalho.

Aos meus amigos Maikon Antônio e Sibery Teodoro que acompanharam bem de perto toda a minha trajetória nesse mestrado, antes mesmo do projeto nascer. Obrigado por ouvirem as inúmeras leituras que fazia com vocês e pelas contribuições que me deram. Um obrigado muito especial a vocês dois!

Ao meu orientador, Prof. Dr. Wender Faleiro e as professoras da Linha de Pesquisa: Leitura, Educação e Ensino de Língua Materna e Ciências da Natureza, prof ${ }^{a}$ Dra. Maria Zenaide Alves, prof ${ }^{a}$ Dra. Selma Matines Peres e a prof ${ }^{a}$ Dra. Maria Aparecida Lopes Rossi. As contribuições de vocês foram fundamentais durante todo o processo, principalmente durante os seminários de pesquisa. Demonstraram em todo tempo um cuidado especial e muito respeito por cada pesquisa, com apontamentos e sugestões relevantes.

Aos colegas da Sexta Turma que foram importantes nesse processo. Aprendi a admirar e respeitar a cada um, pois sei que todos trazem uma história de superação e muita luta e a caminhada não foi fácil. Sentirei saudade das aulas que tivemos juntos, dos seminários e dos calorosos debates. Vencemos!

Ao diretor, Sr. José Adeiro da Fonseca, aos professores e aos agentes socioeducativos, lotados no Centro Socioeducativo de Unaí- CESUN, que foram solícitos ao meu pedido e permitiram a realização desta pesquisa na unidade.

Aos quatorze adolescentes que cumprem medida socioeducativa de internação no CESUN e prontamente se dispuseram a colaborar com este trabalho.

O apoio de cada um tornou possível a conclusão desta pesquisa. 


\section{RESUMO}

Esta pesquisa tem como ponto de partida a tentativa de analisar o processo de formação e (re)socialização de adolescentes em conflito com a lei, que cumprem medida socioeducativa de internação, prevista no artigo 121, da Lei 8.069/90 - Estatuto da Criança e do Adolescente - ECA (BRASIL, 2016), sob a percepção dos próprios adolescentes, que literalmente vivem os estigmas deste sistema, no Centro Socioeducativo de Unaí - MG. Os objetivos específicos consistem em examinar as políticas educacionais que institucionalizaram e assistem a referida unidade; investigar as práticas educacionais desenvolvidas no local, especificamente na escola e, como se articulam com as políticas educacionais voltadas para a formação e (re)socialização dos adolescentes e com as necessidades destes e, por fim, compreender o perfil socioeducacional desses sujeitos, verificando a percepção deles em relação ao Sistema Socioeducativo, sobre o seu processo de formação e (re)socialização e os projetos de vida que constroem, enquanto privados de liberdade. A identificação das ferramentas que compõe todas as políticas e práticas educacionais e, o grau de comprometimento em relação à implantação de todo o projeto pedagógico, socioeducativo e socializador é de fundamental importância para que sejam estabelecidas estratégias específicas para ajudá-los no gerenciamento adequado do programa de (re)socialização pela Educação, com atuação não "através da privação de liberdade" mas, "apesar dela". Assim, fica evidente que a realização desta pesquisa comporta tanto a dimensão jurídica - do Direito, quanto à dimensão pedagógica - da Educação. Esta pesquisa em educação é de abordagem qualitativa. Foram utilizados como instrumentos de coleta de dados a observação, entrevista semiestruturada e questionários para aferir os resultados pretendidos através dos objetivos apresentados. Os questionários foram aplicados a professores e adolescentes, já a entrevista apenas para estes. Em linhas gerais, foi possível concluir que os adolescentes acreditam que as práticas educacionais, as quais estão sujeitos na unidade, contribuem para sua formação e o local é propício a reflexões que favorecem a mudanças no modo de pensar e agir, contribuindo na elaboração de planos e projetos de vida.

Palavras - chave: Formação. (Re)socialização. Adolescente. Medidas Socioeducativas. 


\begin{abstract}
This research starts attempting to analyze the formation and resocialization process of adolescents in conflict with the law, that comply with the socio-educational measure of internment, provided for in the article 121 of Law 8.069 / 90 - of teenager - ECA (BRASIL, 2016), under the perception of the adolescents, who literally live the stigmas of this system, in the Socio - Educational Center of Unaí - MG. The specific objectives consists in examine the educational policies that institutionalized and assist that unit; investigate the educational practices developed in the local, specifically in the school, and how the adolescentes articulate with the educational policies turned on the formation and resocialization of adolescents and their needs, and finally, understand the socio-educational profile of these subjects, checking their perception in relation to the Socio-educational System, about their process of formation and resocialization and the life projects constructed while they are deprived of their liberty. The identification of the tools that make up all educational policies and practices and the grade of commitment about the implementation of the entire pedagogical, socio-educational and socializing project that is extremely important in order to establish specific strategies to help them in the adequate management of the resocialization program by the Education, acting not "through deprivation of liberty" but, "despite it." Thus, it is evident that the accomplishment of this research includes both the legal dimension - of the Law, as well as the pedagogical dimension - of Education. This research in education is qualitative approach. Observation, semi-structured interviews and questionnaires were used as data collect instruments to measure the desired results through the presented objectives The questionnaires were applied to teachers and adolescents, the interview was made only with them. In general terms, it was possible to conclude that the adolescents believe that the educational practices, contribute to their formation and the place is propitious to reflections that favor changes in the way of thinking and acting, contributing in the elaboration of plans and life projects.
\end{abstract}

Keywords: Formation. Resocialization. Adolescents. Socio-educational Measures. 


\section{LISTA DE SIGLAS E ABREVIATURAS}

CCJC - Comissão de Constituição e Justiça e de Cidadania

CEP - Comitê de Ética em Pesquisa

CF/88 - Constituição Federal de 1988

CIA - BH - Centro Integrado de Atendimento ao Adolescente Autor de Ato Infracional

CNJ - Conselho Nacional de Justiça

CNS - Conselho Nacional de Saúde

CONANDA - Conselho Nacional dos Direitos da Criança e do Adolescente

CSEUN - Centro Socioeducativo de Unaí

DIP - Diretoria de Gestão da Informação e Pesquisa

ECA - Estatuto da Criança e do Adolescente

ENS - Escola Nacional de Socioeducação

FUNABEM - Fundação Nacional do Bem-estar do Menor

IBGE - Instituto Brasileiro de Geografia e Estatística

IDH - Índice de Desenvolvimento Humano

LBA - Legião Brasileira de Assistência

LDB - Lei de Diretrizes e Bases da Educação

LEP - Lei de Execução Penal

LF - Lei Federal

LOAS - Lei Orgânica da Assistência Social

MDH - Ministério dos Direitos Humanos

MM - Meritíssimo

OMS - Organização Mundial da Saúde

ONU - Organização das Nações Unidas

OPAS - Organização Pan-Americana da Saúde

PCN - Parâmetro Curricular Nacional

PEC - Proposta de Emenda Constitucional

PNAD - Pesquisa Nacional por Amostra de Domicílios

PNBEM - Política Nacional do Bem-Estar do Menor

PNE - Plano Nacional de Educação

SAM - Serviço de Assistência ao Menor

SDH/PR - Secretaria de Direitos Humanos da Presidência da República 
SEDS - Secretaria de Estado de Defesa Social

SEED/MG - Secretaria Estadual de Educação do Estado de Minas Gerais

SINASE - Sistema Nacional de Atendimento Socioeducativo

SNDCA - Secretaria Nacional dos Direitos da Criança e do Adolescente

SUASE - Subsecretaria de Atendimento Socioeducativo

SUS - Sistema Único de Saúde

UFG - Universidade Federal de Goiás

UNICEF - Fundo das Nações Unidas para a Infância 


\section{LISTA DE FIGURAS}

FIGURA 01 - Adolescentes e Jovens em Restrição e Privação de Liberdade - Total

Brasil (2010-2014) 43

FIGURA 02 - Adolescentes e Jovens por Faixa Etária em Restrição e Privação de Liberdade - Total Brasil (2014) 45

FIGURA 03 - Porcentagem de Adolescentes e Jovens por Raça/cor em Restrição e Privação de Liberdade - Total Brasil (2014) 46

FIGURA 04 - Medidas socioeducativas de internação: percentual dos estabelecimentos quanto aos tipos de atividades desenvolvidas por região 67

FIGURA 05 - Profissionais do SINASE por categoria - Total Brasil em 2014 $-75$

FIGURA 06 - Mapa de Minas Gerais - Mesorregiões Geográficas 107

FIGURA 07 - Localização do Município de Unaí - MG 114

FIGURA 08 - Atos Infracionais - Total Brasil (2014) $-136$ 


\section{LISTA DE QUADROS}

Quadro 1 - Relatos dos Adolescentes sobre o trabalho realizado no CSEUN --------149 


\section{LISTA DE APÊNDICE}

Apêndice A: Quadro cronológico das principais normativas sobre o atendimento

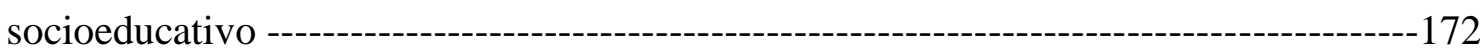




\section{SUMÁRIO}

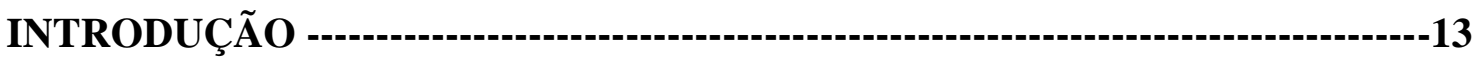

CAPÍTULO 01: A TRAJETÓRIA DAS POLÍTICAS DE ATENDIMENTO À

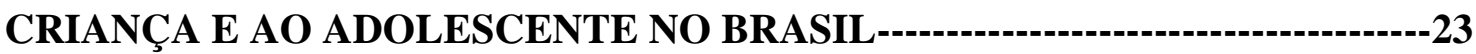

1.1 Instituições especializadas na internação de crianças e adolescentes no Brasil -----23

1.2 Panoramas dos instrumentos jurídicos e políticos voltados às crianças $\mathrm{e}$ adolescentes: as convenções internacionais ------------------------------------------28

1.3 As vicissitudes da Adolescência, o Adolescente e o Ato Infracional ----------------35

CAPÍTULO 02: UM NOVO MARCO NA HISTÓRIA DA CIDADANIA BRASILEIRA - O ESTATUTO DA CRIANÇA E DO ADOLESCENTE---------48

2.1 Origem, princípios, avanços e desafios do ECA ---------------------------48

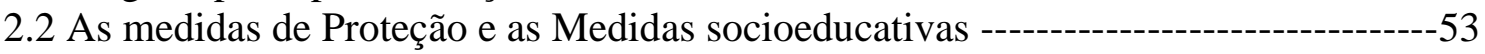

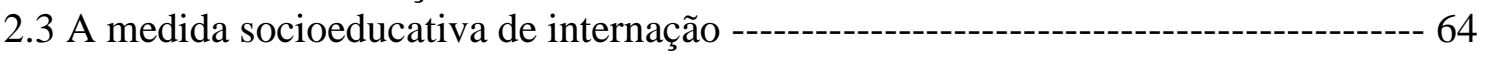

2.4 O Sistema Nacional de Atendimento Socioeducativo - Sinase e a

Lei 12.594/2012 ---on 69

$2.5 \mathrm{O}$ eixo escolarização na medida socioeducativa de internação ------------------- 75

CAPÍTULO 03: PRÁtiCAS EDUCACIONAIS NA FORMAÇ̃̃o E (RE)SOCIALIZAÇÃO DE ADOLESCENTES EM RESTRIÇẨO DE

LIBERDADE -.--- 80

3.1 O que é socioeducação? ---

$3.2 \mathrm{O}$ cárcere e as "celas de aula" -----on

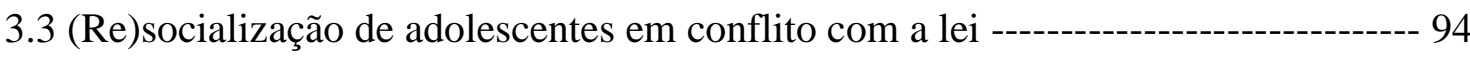

CAPÍTULO 04: CAMINHOS METODOLÓGICOS: A PESQUISA, O LOCAL E

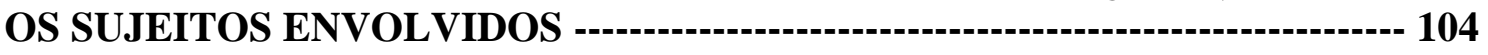

4.1 A escolha da metodologia de pesquisa ---on

4.2 O sistema socioeducativo de internação em Minas Gerais -------------------- 108

4.3 Os sujeitos e o local da pesquisa ---

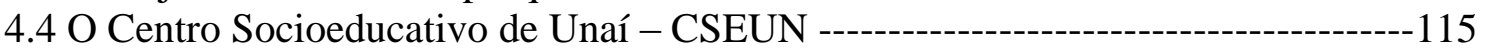

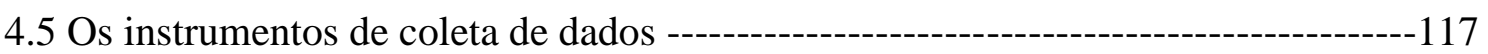

CAPÍTUlO 05: PRÁTICAS E POLÍTICAS EDUCACIONAIS NO CENTRO SOCIOEDUCATIVO DE UNAÍ - CSEUN --

5.1 Como os professores analisam as práticas educacionais na escola do Centro Socioeducativo de Unaí-CSEUN -----on 123

5.2 Os professores no processo de formação e (re)socialização dos alunos ---------- 128

5.3 Os adolescentes privados de liberdade: perfil social, econômico e educacional -- 131 5.4 A percepção dos adolescentes quanto ao processo de formação e

(re)socialização ---

CONSIDERAÇÕES FINAIS ---.-- 154

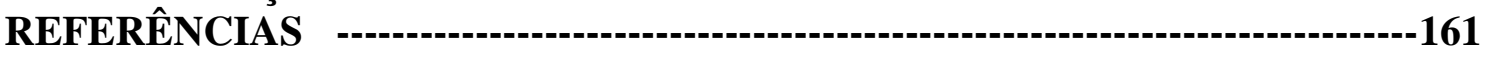




\section{INTRODUÇÃO}

As últimas décadas registraram no Brasil significativas transformações sociais, econômicas e políticas. O crescimento populacional articulado com o fenômeno da urbanização e suas diretrizes, a abertura de novas fronteiras econômicas, políticas, sociais e os avanços tecnológicos vividos nos últimos anos, trouxeram inúmeros benefícios ao país.

As políticas públicas, dentre outros conceitos, consistem em metas e planos pensados para alcançar o bem-estar da população. No entendimento de Peters (1986) são as atividades dos governos, que somadas, agem diretamente ou são delegadas a outros, e influenciam a vida dos cidadãos. Elas têm assistido cada vez mais aos diferentes agentes da sociedade, como as minorias sociais que sofrem com a estigmatização e a discriminação e que são resultados de diversas formas de desigualdade e exclusão social.

Paradoxalmente ao novo cenário, algumas questões cruciais são postas em evidência. Aliado a esse crescimento surgem problemas relacionados à segurança pública, educação, saúde, moradia, emprego, entre outros, e que afetam sistematicamente diferentes classes e segmentos sociais. O Brasil é marcado pela desigualdade social, que se arrasta ao longo dos anos e torna expressivo e urgente a necessidade de pensar e/ou repensar as políticas aqui desenvolvidas.

Assim, neste trabalho, a discussão se restringe apenas ao problema da segurança pública, abordando os atos infracionais análogos a crimes, praticados por adolescentes juridicamente denominados de atores de ato infracional ${ }^{1}$ ou adolescente em conflito com lei.

De início é importante situar as nomenclaturas que serão utilizadas em todo o texto e que estão mais próximas do que propõe o Estatuto da Criança e do Adolescente - ECA, como legislação precursora nas normativas de direitos humanos. Também se propõe discutir o papel libertador e autônomo da educação, nas políticas e práticas socioeducativas, destinadas a formação e (re)socialização dos adolescentes em conflito

\footnotetext{
${ }^{1}$ Aos adolescentes, não se agrega a terminologia 'crime' mas sim, 'ato infracional' conforme reza o ordenamento jurídico. Explicitamente no artigo 103 do Estatuto da Criança e do Adolescente - ECA "o ato infracional é a conduta da criança e do adolescente que pode ser descrita como crime ou contravenção penal". (BRASIL, 2016).
} 
com a lei e que visam assistir a esta fração da sociedade, equacionando os problemas decorrentes.

Outro ponto que merece ser destacado de início é o entendimento que esta pesquisa tem sobre o termo ressocialização, que no texto será apresentado como (re)socialização. O termo ressocialização, no qual Vienne (2005) classifica como psicossocial, é mais comum ser usado pela literatura prisional e também com certa frequência, no vocábulo do senso comum dos gestores políticos dos sistemas escolares, especificamente destinado aos alunos que apresentam desinteresse pelo ambiente escolar.

É importante expor antes do termo ressocialização, e de qualquer reflexão crítica, o que se entende por socialização. Algumas vertentes da sociologia, tanto a clássica quanto a contemporânea, se lançam em estudos que visam identificar os principais agentes no processo de socialização. Os autores Berger e Luckmann (1983), da sociologia clássica, distinguem o processo de socialização em dois momentos: socialização primária e a socialização secundária.

$\mathrm{O}$ primeiro momento corresponde à primeira socialização que a pessoa experimenta na fase da infância e assim torna-se membro da sociedade. É quando ocorre a internalização da realidade mediante as relações sociais que vão se formando. A família e as pessoas mais próximas correspondem ao grupo social responsável pela estruturação da vida psíquica da criança e é o onde estabelecem as primeiras relações sociais. (BERGER; LUCKMANN, 1973).

Já a socialização secundária acontece quando a criança atinge ou inicia o período escolar, envolvendo outros agentes no processo social, como os professores e os colegas da escola. Os autores afirmam que nessa fase a criança traz consigo um mundo que acredita ser só seu (único e verdadeiro) e pode até passar por momentos de crise ao ser exposta a outras realidades. Com isso, afirma que a escola e os professores são os agentes sociais responsáveis pela reafirmação da realidade subjetiva da criança. (BERGER; LUCKMANN, 1973).

Entende-se que, mesmo o adolescente em conflito com a lei não correspondendo aos padrões éticos e morais impostos por nossa sociedade, e em algum momento da sua vida os rompeu ao praticar um ato ilícito, ele ainda está em um contínuo processo de socialização, institucionalizado ou não. Até aqueles que foram privados do convívio direto com seu núcleo familiar na socialização primária ou não tiveram a oportunidade e 
acesso à escola na fase secundária são entendidos como socializados, pois sempre estiveram inseridos em algum contexto social - não cabendo aqui nenhum julgamento quanto a licitude desse contexto.

Da mesma forma, não é pejorativo ou inadequado o termo ressocialização, visto que a usualidade de tal expressão foi apropriada pela literatura prisional. Nesse viés, entende-se que o adolescente em conflito com a lei, ou um preso, estão privados do convívio social (fora da unidade de internação/prisional) e a fase de cumprimento da medida socioeducativa ou da pena deve ser vista como o caminho de preparação para integrá-los novamente ao convívio social. Para Vienne (2005, p. 645) a ressocialização possui um fundo moral que sustenta a ideia de "anular a má socialização" e reconstruir sobre esta uma nova socialização harmoniosa e em sintonia com os padrões sociais estipulados.

A violência e a criminalidade configuram-se como fatores sociais crônicos na atualidade e que atingem direta e/ou indiretamente a todos/as, sem nenhuma distinção de gênero, raça ou condição social, apesar dessas variáveis produzirem diferentes tipos de violência na sociedade (CAVALCANTE, 2014). Sabe-se que o cerne da violência e da criminalidade decorre dos primórdios da História da Humanidade, sendo suas origens e motivações estudadas por várias correntes de pensamento. Esse tema tem sido ocupado tanto pelo poder público, responsável pelo ordenamento jurídico, quanto por áreas de conhecimento, como o Direito, as Ciências Sociais, a Psicologia e a Educação, que tem atuado em pesquisas que objetivam compreender as causas da violência e propor soluções para combatê-las.

Além de todos os problemas vinculados ao elevado índice de criminalidade, torna-se ainda mais agravante o cenário, ao diagnosticar o crescente aliciamento e inserção de adolescentes e jovens neste meio e na configuração destes como atores de atos infracionais. Cada vez mais, adolescentes e jovens tem se envolvido em práticas ilícitas e aflorado um discurso social exacerbado, reforçado pelo poder da mídia, que gera na população medo, sensação de insegurança e dúvida quanto a eficiência da Justiça e a ação das forças policiais. Desde o ano de 1998 os dados do Mapa da Violência no Brasil tem mostrado que a principal vítima da violência homicida no país é a juventude (WAISELFSZ, 2016).

Destarte, surgem inúmeros questionamentos em relação aos fatores que promovem o ingresso desses adolescentes e jovens nas práticas de atos infracionais. 
Dentre as diversas incógnitas está a flexibilidade com que algumas leis são aplicadas; a falta de clareza em definir os reais direitos e deveres dos adolescentes; os mecanismos de prevenção e 'punição' adotados pelas leis em vigência; a instabilidade e falta de limites que caracteriza a fase da adolescência; o papel da escola no processo de formação do cidadão; a estrutura econômica e social das famílias e principalmente as práticas mitigadoras (socioeducativas) de combate aos atos infracionais.

Diante de todas as características expostas, a mais significativa ou talvez complexa, quanto a violência sofrida e praticada pelos jovens, seja a condição de vulnerabilidade social que restringe o acesso (ou oferta um acesso de má qualidade) às estruturas de oportunidade, além das condições econômicas que muitos jovens estão sujeitos e que propiciam a violência e a criminalidade (ABRAMOVAY, 2002).

O quadro dessa situação pode ser comprovado pelo Levantamento Anual Sinase, publicado em 2014, apresentado pelo Ministério dos Direitos Humanos, por meio da Secretaria Nacional dos Direitos da Criança e do Adolescente. Com relação à medida socioeducativa de internação, a série histórica indica um aumento constante e regular no Brasil desde 2010, sendo que neste ano registrou-se o número de 12.041 adolescentes e jovens sujeitos a medida de internação, subindo para 16.902, no ano de 2014. (BRASIL, 2017).

Alguns fatores chamam a atenção no Levantamento Anual SINASE 2014, entre eles as características do/da adolescente e jovem em restrição e privação de liberdade. Um destes fatores é que 95\% dos adolescentes são do sexo masculino - 23.447 e $5 \%$ do sexo feminino, correspondendo a 1.181. Mais da metade destes adolescentes (56\%) possuem faixa etária entre 16 e 17 anos de idade. E ao apresentar a porcentagem de adolescentes e jovens por raça/cor com restrição e privação de liberdade, os dados de 2014 apontaram que 55,77\%, correspondem a cor preta/parda e 21,16\% da cor branca. (BRASIL, 2017).

Ao longo da história do país, diversas instituições foram erguidas no intuito de amparar crianças e adolescentes, leis foram criadas, experiências de atendimento foram implantadas para conter ou sanar os problemas da "delinquência", abandono e criminalidade e, a formação e (re)socialização, vistas por um bom tempo como um mecanismo pelo e para o trabalho. Infância e adolescência foram tratadas ao longo dos anos de múltiplas maneiras, tendo suas relações sociais estabelecidas com a família, 
com a Igreja, com o Estado, que impregnaram valores culturais, religiosos, legais e morais que são reproduzidos até o presente.

Atualmente, o ordenamento jurídico brasileiro é amplo no que se refere a assistir à criança e ao adolescente, mas o reconhecimento destes como sujeitos de direito é uma conquista recente na nossa história. Para Cavalcante (2014), esse novo entendimento contribuiu para que a criança passasse a ser percebida e estudada a partir de suas próprias vozes e não por intermédio do que um adulto fala sobre ela ou por ela e também das memórias de um adulto sobre sua fase de criança.

Nesse viés se consolida o entendimento de sujeito histórico e de direito, defendido no processo de redemocratização de 1988, como um novo marco na história da cidadania brasileira, assegurando plenamente os direitos fundamentais da criança e do adolescente. No entendimento de Cavalcante (2014) ao dizer que o adolescente é um sujeito de direito, cria-se uma categoria social especifica e dá a ele a possibilidade de atuar a partir de suas especificidades, da visão própria de mundo, em sua experiência e relações com os adultos.

O conceito de sujeito de direito não deve ser confundido com o de pessoa de direito. Não devem ser tratados como sinônimos. No entendimento de Castro (2013) tanto são distintos os conceitos que são tratados em temas distintos dentro do Direito Civil, associando pessoa ao instituto da personalidade e sujeito de direito à relação Jurídica.

Para Costa (2013, p. 85) "pessoa é aquele ente que detém personalidade, ou seja, aptidão para titularizar direitos e contrair deveres". Em contrapartida o sujeito de direito "é apenas o ente que o legislador escolheu para outorgar direitos em uma determinada situação, independentemente de ser este ente pessoa ou não, bastando que haja um único direito outorgado" (COSTA, 2013, p.85).

O tema criança e adolescência, no Sistema Jurídico Brasileiro, pode ser analisado em duas fases temporais, sendo a primeira a Doutrina de Situação Irregular e a segunda a Doutrina de Proteção Integral. O divisor de águas está na Doutrina de Proteção Integral, que confere as crianças e aos adolescentes o status de sujeitos de direitos, destinatários de absoluta prioridade, tendo respeitada a condição singular de pessoa em desenvolvimento. Essa nova concepção rompeu com a anterior (Irregular) na qual a criança e o adolescente só eram assistidos quando não estavam inseridos dentro de uma família, ou teriam atentado contra o ordenamento jurídico. (LAMENZA, 2011). 
A Doutrina de Proteção Integral tem como referência importantes documentos internacionais, visto que o Brasil é um país signatário da Convenção dos Direitos da Criança de 1990 e das normativas internacionais que abordam as garantias dos adolescentes no atendimento no sistema de justiça, sendo obrigado a reproduzir alguns princípios, nas ações de proteção àqueles privados de liberdade.

Estes princípios estão expressos nos seguintes documentos internacionais: Regras Mínimas das Nações Unidas para a Administração da Justiça de Menores Regras de Beijing, Resolução 40/33, de 29 de novembro de 1985 - Assembleia Geral das Nações Unidas; Princípios Orientadores de Riad - Princípios Orientadores das Nações Unidas para a Prevenção da Delinquência Juvenil, Resolução 45/112, de 14 de dezembro de 1990 - Assembleia Geral das Nações Unidas - ONU; Regras Mínimas das Nações Unidas para a Proteção dos Jovens Privados de Liberdade - Unicef, adotadas pela Assembleia Geral das Nações Unidas - ONU em 14 de dezembro de 1990, durante o Oitavo Congresso das Nações Unidas sobre a prevenção do delito e do tratamento do adolescente em conflito com a lei.

A atual Doutrina foi introduzida no ordenamento jurídico brasileiro através do artigo 227, da Constituição Federal de 1988 - CF/88 e consolidada suas diretrizes com a promulgação do Estatuto da Criança e do Adolescente - ECA, Lei Federal no $8.069^{2}$, de 13 de Julho de 1990. O compromisso do Brasil com os tratados internacionais induziu a uma revisão legislativa e a pactuações mediante Resoluções e outros instrumentos administrativos, para se adequar às novas concepções e ações no atendimento a adolescentes, atores de ato infracional, que ingressam no sistema socioeducativo, tendo como exemplo a promulgação da Lei 12.594/2012.

O Conselho Nacional dos Direitos da Criança e do Adolescente - CONANDA aprovou e publicou a Resolução $n^{\circ} 119$, no ano de 2006, que estabeleceu o Sistema Nacional de Atendimento Socioeducativo - Sinase. Ainda neste ano, foi encaminhado ao Congresso Nacional um conjunto de propostas com a finalidade de se fazer complementações necessárias no ECA. O resultado destas complementações gerou a Lei Federal no 12.594/2012 que é a normatização conceitual e jurídica, necessária à implementação dos princípios consagrados na Constituição Federal e no ECA, em todo

\footnotetext{
${ }^{2}$ As leis 8.069/90 e 12.594/12 tem como referência bibliográfica a versão no formato PDF (ISBN 978-85402-0504-8), publicada pela Câmara dos Deputados - Série Legislação; n. 237) no ano de 2016 (BRASIL, 2016), atualizada até o dia 15/04/2016. Modo de acesso: http://www.camara.leg.br/editora.
} 
território nacional, referentes à execução das medidas socioeducativas destinadas aos adolescentes em conflito com a lei. (BRASIL, 2016).

Dentro do contexto dessa nova doutrina destaca-se a forma como o Estado protege e/ou responsabiliza os adolescentes, principalmente os atores de ato infracional. O ECA traz um repertório de medidas protetivas elencadas em seu artigo 101, destinadas às crianças que tiverem os direitos ameaçados ou violados, por ação ou omissão da sociedade ou do Estado, por falta, omissão ou abuso dos pais ou responsáveis e em razão da própria conduta. (BRASIL, 2016).

O ECA responsabiliza os adolescentes, atores de ato infracional, por meio de medidas socioeducativas, elencadas em seu artigo 112. As medidas são socioeducativas, pois suas diretrizes preveem um conjunto de práticas políticas, jurídicas e pedagógicas a serem realizadas pelas instituições de atendimento socioeducativo e tem como objetivo maior promover a autonomia dos sujeitos a quem elas assistem. $\mathrm{O}$ referido artigo apresenta seis medidas socioeducativas, sendo elas: advertência; obrigação de reparar o dano; prestação de serviços à comunidade; liberdade assistida; regime de semiliberdade e internação em estabelecimento educacional. (BRASIL, 2016).

O presente estudo tem como lócus de investigação a medida socioeducativa de internação -intervenção estatal de cunho protetivo-pedagógico que constitui na privação de liberdade, sujeita aos princípios da brevidade, excepcionalidade e respeito à condição peculiar de pessoa em desenvolvimento. (BRASIL, 2016). O local escolhido para a realização da pesquisa foi o Centro Socioeducativo de Unaí - CSEUN, localizado no interior do estado de Minas Gerais, na cidade de Unaí. A visita na unidade aconteceu no mês de julho do ano de 2017. Certamente os adolescentes sujeitos a esta medida são os que potencializam e expressam as maiores contradições postas em nossa sociedade, pois ao mesmo tempo em que são sujeitos em desenvolvimento, praticam atos contra a vida e o patrimônio.

A medida socioeducativa de internação é tema que comporta inúmeras abordagens e possibilidades de exploração, como o panorama atual das discussões teóricas e metodológicas, os arranjos institucionais ou das unidades de atendimento socioeducativo, a compreensão das alterações legais, sociais, culturais e políticas que contextualiza $\mathrm{a}(\mathrm{s})$ política(s) de atendimento socioeducativa(s) com a vivência do adolescente inserido e os impactos na sua vida, sua família e comunidade. A medida socioeducativa de internação só atinge seus objetivos - sendo o principal promover a 
autonomia do adolescente, quando em sintonia com todos os parâmetros necessários a gestão e a operacionalização.

Mas, como pensar em todos esses mecanismos de interação sem antes compreender ou dar voz a quem de fato será o alvo principal? Como compreender o processo de formação e (re)socialização inserido na medida socioeducativa sob o olhar dos adolescentes que literalmente vivem sob esta realidade? Muitas pesquisas neste campo têm trazido a lume diversas discussões sobre o perfil do adolescente privado de liberdade, as experiências realizadas nas medidas socioeducativas, experiências socioeducativas das famílias destes adolescentes, a educação e assistência social, redução da idade penal, entre outros. Contudo, poucos trabalhos se preocupam em analisar o Sistema Nacional de Atendimento Socioeducativo sob o olhar do adolescente, sob sua sensibilidade, sob seus argumentos e interpretação.

Nessa seara se inscreve o objetivo principal dessa pesquisa - analisar sob a percepção de adolescentes em restrição de liberdade, o processo de formação e (re)socialização desenvolvido na Unidade de Atendimento Socioeducativo (CSEUN), na cidade mineira de Unaí. Analisar-se-á também a pessoa do adolescente em conflito com a lei, seu perfil, seus projetos de vida, as políticas educacionais que institucionalizaram e assistem a Unidade Socioeducativa, as práticas educacionais desenvolvidas na Unidade/Escola e, como se articulam com as Políticas educacionais voltadas para a formação e (re)socialização dos adolescentes.

A identificação das ferramentas que compõe todas as Práticas e Políticas educacionais e do grau de comprometimento em relação à implantação do Projeto Político Pedagógico pelos gestores e atores de todo o sistema é de fundamental importância para que sejam estabelecidas estratégias específicas para ajudá-los no gerenciamento adequado do programa de inclusão e socialização por meio da Educação. Assim, fica evidente que a realização desta pesquisa comporta tanto a dimensão jurídica - do Direito, quanto à dimensão pedagógica - da Educação.

O primeiro capítulo - A trajetória das políticas de atendimento à criança e ao adolescente no Brasil, tem o intuito de contextualizar o tema pesquisado por meio de uma breve incursão histórica no surgimento de instituições especializadas na internação de crianças e adolescentes no Brasil. Apresenta uma sucinta análise sobre as convenções internacionais dos direitos da criança e do adolescente e o que se configura como Ato Infracional. Ainda neste capítulo será apresentada algumas características que 
configuram o/a adolescente e as transformações vividas na fase da adolescência, buscando compreender os possíveis fatores de ligação com o ato infracional.

O segundo capítulo, que traz o título Um novo marco na história da cidadania brasileira - o Estatuto da Criança e do Adolescente, apresenta ao leitor os princípios norteadores que deram origem a promulgação da Lei 8.069/90, conhecida como o Estatuto da Criança e do Adolescente - ECA. Por ser tratar de um marco na história da cidadania brasileira é imprescindível que se compreenda quais os princípios defendidos por essa Lei, os mais relevantes desafios e os avanços alcançados nos seus quase 28 anos de existência. Será feita uma descrição sobre as medidas protetivas e as medidas socioeducativas, previstas no texto legal, com um tópico específico para a medida socioeducativa de internação - única trabalhada nesta pesquisa. E por fim, o capítulo 02 apresentará a Lei 12.594/12, marco normativo que institui o Sistema de Atendimento Socioeducativo - Sinase em todo território nacional, destacando os pontos mais relevantes, como o eixo escolarização na medida socioeducativa de internação.

Já no capítulo 03 - Práticas educacionais na formação e (re)socialização de adolescentes em restrição de liberdade, serão apresentadas breves considerações sobre a educação social e o eixo socioeducativo, principalmente, nas medidas socioeducativas elencadas no ECA. Pretende-se trazer uma compreensão dos espaços de controle e privação de liberdade e dos sujeitos inseridos, que criam e recriam o espaço e a vida social no contexto onde vivem. Nesse capítulo também serão apresentados os conceitos apropriados nesta pesquisa no que tange aos temas socialização e ressocialização, comumente usados pela literatura clássica e contemporânea da sociologia.

O quarto, intitulado Caminhos metodológicos: a pesquisa, o local e os sujeitos envolvidos, apresenta os passos metodológicos utilizados na pesquisa. No primeiro momento será feita uma descrição sobre Pesquisa Educacional, os principais problemas relacionados às pesquisas e sobre a abordagem qualitativa de pesquisa. Em seguida, será apresentada a pesquisa em análise, sendo exposto o objetivo geral, bem com os específicos, a justificativa e o problema que deu origem a mesma. Por fim, a que tipo de investigação se refere, seu rigor científico, os instrumentos que serão utilizados, os mecanismos que constituirão a coleta dos dados e a análise dos mesmos, até chegar ao seu produto. Importante ressaltar que nesse capítulo serão apresentados alguns dados sobre o Sistema Socioeducativo de internação no estado de Minas Gerais e a caracterização do Centro Socioeducativo de Unaí - CSEUN. 
No último capítulo - Práticas e Políticas Educacionais no Centro Socioeducativo de Unaí- CSEUN, será apresentado, de forma detalhada, os resultados e as discussões, com a finalidade de demonstrar qual a percepção que os adolescentes em restrição de liberdade possuem em relação ao processo de formação e (re)socialização desenvolvidos no CSEUN. 


\section{CAPÍTULO 01}

\section{A TRAJETÓRIA DAS POLÍTICAS DE ATENDIMENTO À CRIANÇA E AO ADOLESCENTE NO BRASIL}

O objetivo deste capítulo é contextualizar o tema pesquisado por meio de uma análise histórica sobre o surgimento de instituições especializadas na internação de crianças e adolescentes no Brasil. A proposta é conduzir o leitor aos principais marcos históricos e mostrá-lo como o tratamento e as nomenclaturas eram destinadas às crianças e adolescentes em conflito com a lei, por parte do Estado e da sociedade. Apresenta uma sucinta descrição das principais convenções e tratados internacionais, destinados ao atendimento de criança e de adolescente, bem como aqueles no qual o Brasil é signatário. E, por fim, traz uma análise sobre as sucessões de mudanças ou de alternâncias que ocorrem na fase da adolescência, propondo uma conexão entre o que é ser adolescente, a adolescência e o ato infracional.

\subsection{Instituições especializadas na internação de crianças e adolescentes no Brasil}

A história do Brasil revela grandes conquistas sociais e de direito à educação, direcionadas às crianças e adolescentes, graças principalmente as transformações históricas, políticas e pedagógicas. Tendo como exemplo a Constituição Federal de 1988, esta rompe os paradigmas que caracterizava o Estado apenas como um instrumento de controle e legitimação da ordem política e social, e estabeleceu o marco legal da transição democrática e da institucionalização dos direitos humanos no Brasil. (BRASIL, 1988).

Outro avanço histórico que rompe com a concepção arcaica de infância e juventude enraizada no imaginário da população foi a promulgação da Lei 8.069, em 13 de Julho do ano 1990, conhecida como o Estatuto da Criança e do Adolescente - ECA. Uma legislação moderna que traz um rol de direitos civis, sociais, econômicos e culturais de promoção e proteção integral à criança e ao adolescente, assegurando-se lhes, por lei ou por outros meios, oportunidades e facilidades, a fim de lhes facultar o desenvolvimento físico, mental, moral, espiritual e social, em condições de liberdade e de dignidade. (BRASIL, 2016). 
De fato, o ECA pode ser considerado um marco nas políticas sociais destinadas ao atendimento à criança e ao adolescente, principalmente aqueles em conflito com a lei, e permite caracterizar todo o percurso histórico, antes e após a sua promulgação. Um processo histórico que no passado pode ser compreendido pelo controle e exclusão social sustentado na Doutrina de Situação Irregular que será apresentada adiante.

Tomando como viés neste texto os adolescentes em conflito com a lei, o ECA sinalizou em seu artigo 112 as medidas socioeducativas, de aspecto coercitivo e educativo, proporcionando condições que garantam o acesso do adolescente a participação na vida social. Vinte e dois anos depois seria promulgada a Lei 12.594/12 que instituiu em todo território o Sistema Nacional de Atendimento Socioeducativo Sinase. (BRASIL, 2016).

O Brasil possui uma longa tradição histórica em internação de crianças e adolescentes em instituições assistenciais do tipo internato. Diversas instituições foram estabelecidas no intuito de amparar crianças e adolescentes, leis foram criadas, experiências de atendimento foram implementadas para conter ou sanar os problemas da "delinquência", abandono e criminalidade. Ao debruçarmos sobre a história é possível perceber que a infância e adolescência foram tratadas ao longo dos anos de múltiplas maneiras, tendo suas relações sociais estabelecidas com a família, com a Igreja, com o Estado. Estas instituições impregnaram valores culturais, religiosos, legais e morais que ainda são reproduzidas no cenário atual.

Tomando como ponto de partida o período Colonial, de acordo com Rizzini e Irma (2004), foram criados no país colégios internos, seminários, asilos, escolas de aprendizes artífices, educandários, reformatórios, dentre outras instituições voltadas para educação e assistência social. As crianças e adolescentes "desvalidos", que segundo as autoras seriam os órfãos, abandonados, negligenciados, maltratados e delinquentes, existiram em todos os tempos (RIZZINI; PILOTTI, 2011). O que mudou no decorrer da história foram os responsáveis por eles, na rede de assistência, realizada tanto por setores públicos quanto privados da sociedade.

A principal característica do período Colonial, em relação à institucionalização de crianças e adolescentes, está relacionada aos representantes da Corte e da Igreja Católica. Estado e Igreja eram aliados neste período. Os padres da Companhia de Jesus, ou também conhecidos como Soldados de Cristo eram os responsáveis pelo cuidado das crianças índias, no intuito de tirá-las do paganismo e discipliná-las de acordo com os 
princípios e costumes cristãos. Os Jesuítas criaram escolas elementares, de ler, escrever e contar, para crianças das aldeias indígenas e dos vilarejos e criou colégios para formação religiosa e instrução superior para os filhos dos mais privilegiados daquela sociedade (RIZZINI; IRMA, 2004). Os referidos religiosos foram os principais agentes educacionais até o ano de 1759, quando foram expulsos pelo Marquês de Pombal, conforme conta-nos a História e ratifica as autoras.

Outro importante recorte histórico que surgiu no período Colonial e se estendeu até a República foi a institucionalização das crianças conhecidas como "expostas", as quais eram de responsabilidade das Câmaras Municipais e da Santa Casa de Misericórdia. As crianças geradas fora dos casamentos ou nascidas em famílias pobres que não tinham condições de criá-las eram, neste período, abandonadas em locais públicos, como portas de igrejas e casas. Assim, surgiu o sistema da Roda, implantado pela Santa Casa. Esta roda, conhecida também como Roda dos Expostos era um cilindro giratório colocado nas paredes que permitia que crianças rejeitadas fossem colocadas da rua para o interior, sem que o responsável pelo abandono fosse identificado. O cuidado das crianças passava a ser proveniente de doações e elas eram alimentadas pelas chamadas amas-de-leite. A primeira Roda dos Expostos foi criada em 1726, na Bahia e depois se estendeu para outras localidades. Apenas no ano de 1927 foram extintas formalmente (RIZZINI; PILOTTI, 2011).

No período Imperial (1822 - 1889), a institucionalização da infância era vista como objeto de controle por parte do Estado, decorrentes das instituições do tipo internatos de menores. Os internatos eram modelos de educação escolar resultantes de iniciativas múltiplas, como das ordens religiosas, particulares leigos e poderes públicos, que via neles uma forma de assistência e controle social. Os menores delinquentes, infratores ou desvalidos eram inseridos neste contexto, além do atendimento prestado à "boa sociedade", ao se referirem aos alcoólatras, idosos, dependentes químicos, crianças portadoras de necessidades especiais, entre outros (GONDRA; SCHUELER, 2008).

A concretização da experiência brasileira de intervenção especializada junto aos menores de idade em conflito com a lei é iniciada, de fato, no período do Regime Republicano (RIZZINI, 2005). Em 1927 foi promulgado o Código de Menores no intuito de regulamentar a assistência e a proteção aos menores abandonados e delinquentes. Segundo Perez e Passone (2010, p. 655) “o Estado incorporou o debate sobre a salvação da criança e sobre a regeneração social, alçando a criança a alvo das 
ações públicas e responsabilizando e punindo as famílias em relação aos cuidados à infância”. A principal característica era a visão jurídica, médica e assistencial que pautava esse ordenamento jurídico. Para os referidos autores, além de assistirem à saúde das crianças, o Estado intervinha quando ocorria o abandono físico e moral, retirando a tutela dos pais e internando os abandonados e os atores de infração penal.

Os autores Freitas e Biccas (2009) na obra História da Educação no Brasil (1926-1996) afirmam que o Código de Menores encerrou um ciclo de abordagens da questão social relacionadas a infância, com muitas contradições e que

[...] o Estado começa a assumir obrigações mais definidas que combinam assistência com repressão. A repressão não é instituída unilateralmente de cima para baixo, como se o Estado a criasse de forma dissociada da sociedade. O Estado a legitima e a regulamenta materializando aquilo que, pelo menos para uma parte da sociedade, pode ser chamada de "visão de mundo" em relação à infância (FREITAS; BICAS, 2009, p. 48).

O período de 1930-1945 - caracterizado pelo rompimento da sociedade de base agrária para urbana e industrial é marcado pelo autoritarismo populista com a instituição do Governo Provisório da República (1930-1934) e a ditadura do Estado Novo (19371945). As principais características ocorridas neste recorte histórico foram os avanços no serviço social de atendimento infantil e a organização da proteção a maternidade e a infância. Neste período foram criados o Departamento Nacional da Criança (Decreto Lei $n^{\circ} 2.024$ de 1940), o Serviço de Assistência ao Menor - SAM (Decreto no 3.799 de 1941) e o estabelecimento da Legião Brasileira de Assistência - LBA (PEREZ; PASSONE, 2010).

O SAM foi a concretização do projeto almejado no governo ditatorial de Getúlio Vargas para intervir junto à infância de forma centralizada. Rizzini (2004) discorre que no projeto de expansão nacional do SAM o objetivo era assistir aos "autênticos desvalidos" (sem responsáveis pelas suas vidas) mas acabou recebendo maior destaque com os chamados "transviados". Apenas pelo fato de passar pelo SAM fazia com que os adolescentes ficassem temidos e "marcados" pela sociedade, como se fosse uma escola do crime (RIZZINI, 2004).

Ainda neste período, no ano de 1943 foi aprovado o Decreto $\mathrm{n}^{\circ} 6.026$ que continha as medidas que deveriam ser aplicáveis aos menores de dezoito anos pela prática de atos considerados como infrações penais. Este Decreto redefiniu as competências do SAM e segundo Faleiros (2011) deveriam, além de outras atribuições, 
diagnosticar os casos de internação e ajustamento social por meio de exames médicopsicopedagógicos e encaminhar e abrigar os menores aos estabelecimentos apropriados. O SAM só seria extinto com a mudança de regime político em 1964 (RIZZINI, 2005).

Os anos de 1945 a 1964 são conhecidos como o período da Democracia Populista. As principais características no que tange a institucionalização de crianças e adolescentes foi a manutenção do aparato legal e regulamentação dos serviços de adoção no país. Dentre as principais normatizações e legislações, Perez e Passone, (2010), destacam a criação do Serviço de Colocação Familiar (Lei n ${ }^{\circ}$ 560/1949), Serviço Nacional de Merenda Escolar (Decreto 37.106 de 1955), Instituto de Adoção (Lei no 4.269/1957) e a criação da Lei de Diretrizes e Bases da Educação - LDB (Lei no $4.024 / 1961)$.

O período de 1964-1985, um dos mais expressivos na história do Brasil, foi caracterizado pela Ditadura Militar e pela criação de uma política que pouco se distanciava do tratamento dispensado à infância e a juventude no período anterior, a Política Nacional do Bem-Estar do Menor -PNBEM, criada no interior da Escola Superior de Guerra (DIAS \& ONOFRE, 2013). O antigo SAM foi transformado na Fundação Nacional do Bem-estar do Menor - Funabem. Dentre os objetivos do Funabem, um deles seria criar diretrizes contrarias as criticadas no SAM. Este período também se caracterizou pela diminuição da idade penal para 16 anos (Lei no 5.258 de 1967), pelo acordo firmado entre o Fundo das Nações Unidas para a Infância - UNICEF e o governo (Decreto $n^{\circ}$ 62.125/68) e pela instituição do novo Código de Menores (Lei no 6.697/79) (PEREZ; PASSONE, 2010).

Uma característica peculiar neste período, apontada por alguns autores (PEREZ; PASSONE, 2010; RIZZINI, 2004; RIZZINI, 2005) foram as contradições entre a realidade vigente e as recomendações das convenções internacionais sobre o direito da infância. O Fundo das Nações Unidas Para a Infância - UNICEF teria firmado um acordo em 1968 com o Governo brasileiro e, em plena ditadura militar, este ratificaria os preceitos da Declaração Universal dos Direitos da Criança. Porém na prática, aprovou um novo Código de Menores em 1979, ainda mais repressivo que o Código de Menores da Primeira República.

O último período, caracterizado pela abertura democrática no país, consiste em descrever a atual configuração brasileira com a promulgação da Lei 8.069/1990 - 
Estatuto da Criança e do Adolescente - ECA e após este, com a criação da Lei 12.594/2012 que instituiu o Sistema Nacional de Atendimento Socioeducativo - Sinase.

Dentre as principais características deste período atual destaca-se o novo padrão político, jurídico e social que se estabeleceu com a institucionalização da infância e da adolescência como sujeito de direito e a consolidação de um sistema de proteção integral. A criança e o adolescente são reconhecidas como novo grupo político e social, com direitos e garantias legais, que não pode mais ser atendido por meio de programas isolados e assistencialistas, constituindo-os como cidadãos, independente da classe social, gênero, cor, raça e religião (PEREZ; PASSONE, 2010; DIAS; ONOFRE, 2013).

\subsection{Panorama dos instrumentos jurídicos e políticos voltados às crianças e adolescentes: as convenções internacionais}

É tema recorrente na literatura especializada em crianças e adolescentes a preocupação e necessidade de dispensar a estes, tratamento diferenciado, em um princípio de cooperação entre Estado, sociedade, órgãos internacionais e a própria família, visto que estão em uma situação peculiar de desenvolvimento. A condição de incapacidade e/ou vulnerabilidade total ou parcial de crianças e adolescentes, tem levado órgãos internacionais a desenvolverem e aprimorarem tratados de cunho internacional de proteção e amparo dos infantes.

O Brasil, no que se refere a sua posição em relação ao sistema internacional de proteção, somente após o período ditatorial em 1985, no momento histórico intitulado de redemocratização é que passou a ratificar tratados internacionais que versam sobre direitos humanos. E só a partir da Constituição Federal de 1988, seguida do Estatuto da Criança e do Adolescente é que o país passou a ser orientado por um novo modelo direcionador de ações e políticas públicas destinadas a autonomia da infância e da adolescência (NAVES; GAZONI, 2010).

A CF/88 apresenta um rol de direitos fundamentais, individuais, coletivos ou sociais, cuja origem remete a Declaração Universal dos Direitos Humanos, de 1948, aprovada pela Assembleia Geral das Nações Unidas - ONU. Representa um marco legal na transição democrática no país. Para Piovesan (2013)

[...] o valor da dignidade da pessoa humana, elevado a princípio fundamental, impõe-se como núcleo básico informador do ordenamento jurídico brasileiro, como critério e parâmetro de valoração a orientar a interpretação e a compreensão do sistema 
constitucional instaurado. (PIOVESAN, 2003, p.13).

Seguindo uma ordem cronológica de criação serão apresentados os principais tratados e acordos dos quais o Brasil é signatário e que contribuíram para seu processo de redemocratização e criação do ECA - Lei 8.069/1990.

\section{a) Declaração Universal dos Direitos Humanos - Resolução 217-A, 1948}

A Declaração Universal dos Direitos Humanos ${ }^{3}$ foi adotada e proclamada pela Assembleia Geral das Nações Unidas - ONU em 10 de dezembro de 1948, reconhecendo a necessidade do direito à vida, igualdade, liberdade, justiça social e paz global para todos os seres humanos (SILVA, 2012). O texto começa por citar a liberdade e igualdade de todos os seres humanos, e exclui a possibilidade de qualquer distinção. Estabelece então como prioridade o direito à vida, liberdade e segurança. Proíbe sob qualquer circunstância a escravidão e seus análogos, tortura e a exclusão de direitos civis (ONU, Resolução 217 A III, 1948).

O texto traz logo em seu preâmbulo, de modo elucidativo que

[...] A ASSEMBLÉIA GERAL proclama a presente DECLARAÇÃO UNIVERSAL DOS DIRETOS HUMANOS como o ideal comum a ser atingido por todos os povos e todas as nações, com o objetivo de que cada indivíduo e cada órgão da sociedade, tendo sempre em mente esta Declaração, se esforce, através do ensino e da educação, por promover o respeito a esses direitos e liberdades, e, pela adoção de medidas progressivas de caráter nacional e internacional, por assegurar o seu reconhecimento e a sua observância universal e efetiva, tanto entre os povos dos próprios Estados-Membros, quanto entre os povos dos territórios sob sua jurisdição. (ONU, Resolução 217 A III, 1948).

Aplica-se também o princípio da presunção de inocência; determina a data da infração como a data do ato e não dos resultados, proibindo pena mais grave que a vigente no momento em que aconteceu o delito. A declaração ainda reforça o direito de ir e vir, bem como o direito de pedir asilo político por perseguição infundada. A proteção ao núcleo familiar, o direito de propriedade, à liberdade de culto e de opinião (SILVA, 2012).

No que tange aos direitos da criança e do adolescente, frise-se o artigo 25, item

${ }^{3}$ Declaração Universal dos Direitos Humanos - Resolução 217-A, 1948. Disponível em <http://unesdoc.unesco.org/images/0013/001394/139423por.pdf>. 
2, que atribui a maternidade e a infância direitos especiais, sem, no entanto, elucidar o que seriam estes, fazendo apenas alusão a necessidade de maior atenção e cuidado nestas circunstâncias. $\mathrm{O}$ artigo 26 desta Declaração estabelece o direito à instrução no mínimo em níveis básicos e com contornos de tolerância e respeito entre grupos de todos os tipos. Por fim, o texto elucida que todos os direitos são limitados pelos direitos de outrem (ONU, Resolução 217 A III, 1948).

\section{b) Declaração dos Direitos das Crianças - 1959}

A Declaração dos Direitos das Crianças ${ }^{4}$ foi promulgada pela ONU em 20 de novembro de 1959. É outro importante documento internacional no qual o Brasil é signatário e surge dez anos mais tarde com um texto específico para o direito infantil. São dez princípios que compõe a declaração. Todos salientam a necessidade de especial proteção aos pequenos e suas mães, com oportunidades de desenvolvimento físico, mental e emocional. Às crianças é assegurado o direito à saúde e cuidados médicos especiais, quando for o caso. Estabelece ainda o dever de priorizar sempre a permanência da criança no seio familiar, sendo nutrida de afeto e segurança. Novamente a declaração pede um ambiente de tolerância e fraternidade.

Os dez princípios que compõe o texto são: direito a igualdade, sem distinção de raça, religião, sexo ou nacionalidade; direito à proteção especial para seu desenvolvimento físico, mental e social; direito a um nome e a uma nacionalidade; direito à alimentação, à moradia e à assistência médica adequada para a criança e a mãe; direito à educação e a cuidados especiais para a criança física ou mentalmente deficiente; direito ao amor e à compreensão por parte dos pais e da sociedade; direito à educação gratuita e ao lazer; direito a ser socorrido em primeiro lugar, em caso de catástrofe; direito a ser protegido contra o abandono e a exploração no trabalho e direito a crescer dentro de um espirito de solidariedade, compreensão, amizade e justiça entre os povo.

\footnotetext{
${ }^{4}$ Declaração dos Direitos das Crianças - 1959. Disponível em: <www2.camara.leg.br>.
} 


\section{c) Pacto Internacional dos Direitos Civis e Políticos - ONU - 1966}

Editado em dezembro de 1966, foi adotado formalmente pelo Brasil apenas em dezembro de 1991 através do Decreto Legislativo número $226^{5}$. O tratado ratifica os documentos criados anteriormente e acima citados e estabelece ainda que os recémnascidos devam ser registrados de imediato, tendo direito a receber um nome e nacionalidade (ONU, 1996).

\section{d) Convenção Americana Sobre Direitos Humanos (Pacto de San José da Costa Rica)}

A Convenção ocorreu em novembro de 1969, sendo ratificada pelo Brasil em novembro de 1992. Seu principal objetivo foi estabelecer diretrizes mínimas para respeito aos direitos humanos básicos, estabelecendo que seus direitos não possuem vínculo com o Estado em que se insere. São princípios norteadores para as leis estaduais. O texto não fala especificamente do direito infanto-juvenil, mas seu conteúdo é perfeitamente aplicável a esta faixa etária (SILVA, 2012).

\section{e) Convenção no 138 - OIT - 1973}

Convocada em Genebra pelo Conselho de Administração do Secretariado da Organização Internacional do Trabalho - OIT e reunida a 06 de junho de 1973, ficou também conhecida como Convenção sobre a Idade Mínima. No que tange à criança e ao adolescente, estabeleceu o comprometimento dos Estados signatários de abolirem totalmente o trabalho infantil, sendo permitido admissão no emprego ou trabalho quando compatível com o pleno desenvolvimento físico e mental do jovem. O documento só foi ratificado pelo Brasil em 18 de junho de 2001 (NAVES; GAZONI, 2010).

${ }^{5}$ Decreto Legislativo número 226 Disponível em <http://legis.senado.gov.br/legislacao/ListaPublicacoes.action?id=135720>. 
f) Regras Mínimas das Nações Unidas para a Administração da Justiça de Menores - Regras de Beijing. Resolução 40/33, de 29 de Novembro de 1985 - Assembleia Geral das Nações Unidas

O tratado ${ }^{6}$ em questão não foi formalmente ratificado em território nacional, mas, serviu como norteador do ECA, tendo então seus princípios inseridos nas políticas nacionais acerca do assunto. As discussões sobre o assunto tiveram início no sexto congresso da ONU, realizado na capital venezuelana no ano de 1980, com o tema de prevenção dos delitos e administração de delinquentes. Em 1985 foi apresentado o documento em Pequim. Fez-se então a composição das regras mínimas que deveriam estar presentes no ato punitivo de menores, atores de ato infracional. $\mathrm{O}$ texto salienta a importância da proporcionalidade nas penas aplicadas, tendo em vista a condição singular do ator de ato infracional (menor de idade). O documento salienta que a juventude possui período em que a propensão à delinquência é majorada em decorrência dos processos de desenvolvimento próprios do jovem (FERRANDIN, 2009).

\section{g) Declaração Mundial Sobre a Sobrevivência, a Proteção e o Desenvolvimento das Crianças nos Anos 90 - set/90 - Sede das Nações Unidas}

Conforme o próprio nome sugere, a declaração ${ }^{7}$ trata da sobrevivência de crianças, tendo como prioridade o bem-estar de todas. Com a assinatura do documento e a adoção do "Plano de Ação" para a década de 90, os líderes mundiais que se reuniram no Encontro Mundial de Cúpula pela Criança, realizado nas Nações Unidas, em Nova lorque, no dia 30 de setembro de 1990, propuseram metas para assuntos diversos, como redução da mortalidade infantil, saneamento básico, acesso à água, erradicação da fome e consequente desnutrição. A declaração ainda incentivou mais acesso aos estudos, diminuição do trabalho infantil, proteção contra guerras. $O$ texto entra ainda em um tema mais econômico, atribuindo aos países desenvolvidos à obrigação de mitigar impedimentos comerciais ao crescimento dos países em desenvolvimento (ONU, 1990).

\footnotetext{
${ }^{6}$ Regras Mínimas das Nações Unidas para a Administração da Justiça de Menores. Disponível em <http://www.sdh.gov.br/assuntos/criancas-e-adolescentes/pdf/SinaseRegrasdeBeijing.pdf $>$.

7 Declaração Mundial Sobre a Sobrevivência, a Proteção e o Desenvolvimento das Crianças nos Anos 90 - set/90 - Sede das Nações Unidas. Disponível em < https://www.unicef.org>.
} 


\section{h) Diretrizes das Nações Unidas Para a Prevenção da Delinquência Juvenil - Diretrizes de RIAD - Dez/1990}

As Diretrizes de RIAD foram adotadas e proclamadas pela Assembleia Geral das Nações Unidas na sua resolução 45/112, de 14 de Dezembro de 1990 e aborda um pouco mais o contexto penal que envolve a juventude. $O$ texto entende a delinquência juvenil como parte importante da segurança social, sendo necessário investir no bemestar infanto-juvenil para mitigar o desenvolvimento negativo dos jovens. $\mathrm{O}$ texto incentiva ainda que sejam criadas políticas públicas para o assunto, bem como programas comunitários que possibilitem a prevenção da delinquência (DUTRA, 2006). Cumpre esclarecer que o documento não possui caráter normativo no Brasil, entretanto, serviram de inspiração para a composição do ECA - Estatuto da Criança e do Adolescente (FERRANDIN, 2009).

\section{i) Regras mínimas das nações unidas para proteção dos jovens privados de liberdade - Dez/1990 ${ }^{8}$}

No mesmo congresso em que foram editadas as Diretrizes de RIAD, foram descritas as regras básicas para se aplicar medidas de restrição à liberdade do menor autor de ato infracional. Essa preocupação justifica-se pelas condições em que os jovens são privados da sua liberdade em todo o mundo, pelo fato de serem altamente vulneráveis aos maus tratos, vitimização e violação dos seus direitos e por muitos sistemas não diferenciarem adultos e jovens nos vários estágios da administração da justiça e com o fato de os jovens serem assim detidos em prisões e outros estabelecimentos com adultos, conforme traz expressamente no texto (ONU, 1990).

A convenção entende que a medida de privação de liberdade, no caso dos adolescentes, deverá ser aplicada apenas como recurso final e pelo menor prazo possível. Orientam que sejam assistidos durante o processo de reclusão e após. O texto possui um notório comprometimento com a inserção do jovem novamente na sociedade, inclusive propiciando ao privado de liberdade a participação em estágios e liberação antecipada (se for o caso). O trabalho de regresso à sociedade deverá ter início antes da soltura, com medidas que possibilitem menor discriminação do adolescente, meios de subsistência e vestuário adequado (ONU, 1990).

\footnotetext{
${ }^{8}$ Disponível em: < http://www2.camara.leg.br/atividade-legislativa/comissoes >.
} 


\section{j) Convenção sobre os Direitos da Criança}

Trata-se de um dos documentos internacionais mais abrangentes sobre os direitos das crianças (PEREIRA, 1992). A convenção busca propor meios de proteção a famílias, núcleo central da sociedade e meio pelo qual ela poderá crescer e gerar bemestar a seus membros. Neste contexto, a criança surge como o ente mais frágil na estrutura familiar, necessitando, portanto, de maiores cuidados decorrentes de sua imaturidade física e emocional (DAVID, 2003). Sendo uma convenção, o texto aglutina o "de acordo" de vários países sobre direitos e seguranças que deverão ser tutelados pelos Estados. Seus signatários, mais que simplesmente concordar com direcionamentos, assumem o compromisso de efetivamente aplicar as determinações convencionadas (DUTRA, 2006). Esse novo texto além de ampliar os direitos já evidenciados em outros tratados internacionais, torna o assunto mais palpável em conteúdo e aponta determinações de forma mais direta (SORALI, 1994).

\section{k) X Cúpula Ibero-Americana de Chefes de Estado e de Governo - Declaração do Panamá "unidos pela infância e adolescência, base da justiça e da equidade no novo milênio" - 2000}

Participaram da cúpula, realizada na República do Panamá, vinte e um países Ibero-Americanos, reconhecendo a importância do tratamento adequado de crianças e adolescentes para a sobrevivência das sociedades de forma pacífica, ordenada e sustentável. Várias instruções foram discutidas como igualdade, respeito às diversidades (inclusive linguística), acesso à educação básica, segurança, nutrição, saúde, educação sexual (com incentivo a comportamentos responsáveis como uso de contraceptivos) e políticas de inclusão para menores portadores de necessidades especiais. As medidas não apenas atingem de forma imediata crianças e adolescentes dos países signatários, como também cria condições de sustentabilidade para o bem-estar socioeconômico de gerações futuras (FERRANDIN, 2009). 


\subsection{As vicissitudes da Adolescência, o Adolescente e o Ato Infracional}

Os estudos sobre adolescência e adolescente decorrem de uma tessitura de pesquisas, que transitam por diferentes linhas de conhecimento, desde o âmbito jurídico, psicológico, sociológico, educacional, dentre outros. Esta fase, de expressivas mudanças no ser humano, será apresentada aqui pelo viés das transformações de critérios no curso da história do ocidente até o presente tempo, explorando apenas os aspectos mais relevantes dessa ampla discussão.

A adolescência é uma fase extremamente especial do desenvolvimento humano. Em diversas culturas e povos, a adolescência é compreendida como importante e significativo momento de domínio dos valores da vida social, controle das regras, de autonomia, amadurecimento físico e psíquico e da incorporação das funções e papéis sociais do mundo adulto que transitarão. (LEVISKY,1998).

No que tange a delimitação dessa fase da vida, a adolescência não pode ser efetivamente mensurável pela quantidade de anos. A Organização Pan-Americana da Saúde (OPAS)/Organização Mundial da Saúde (OMS) (1990) e Ministério da Saúde (1989) a delimitam entre os 10 e os 19 anos de idade e a juventude dos 15 aos 24 anos de idade. Todavia para o Estatuto da Criança e do Adolescente - ECA, e o parâmetro utilizado neste trabalho, a adolescência abrange a fase dos 12 aos 18 anos de idade. (ASSIS; DESLANDES; SANTOS, 2005; BRASIL, 2016).

Nem sempre as concepções da fase da adolescência foram claras e bem delimitadas. De acordo com Levisky (1998) até meados do século XVI não havia uma diferenciação entre infância, juventude e velhice. A expressão juventude significava "força da idade", destinada a uma idade mais tardia, sem lugar assim para a adolescência. Durante os séculos XVII e XVIII não havia uma discriminação programática nem de atividades destinadas às particularidades da fase da adolescência, tendo como exemplo o fato de crianças de 10 e jovens de 25 anos de idade frequentarem a mesma classe escolar.

As sociedades tendem, com suas regras, leis, costumes e tradições, estabelecerem as modalidades que vão definir o período de infância e o período adulto. De acordo com Souza-Leite (2008) o primeiro autor que considerou a adolescência como uma realidade clara e distinta da fase da infância e da fase adulta foi Rousseau (1712-1778). Faz referência ao clássico livro 'Emílio ou da Educação', que descreve a 
adolescência como uma etapa específica da vida humana que possui características bem definidas. Para Rousseau (1985) citado por Souza-Leite (2008, p.64) a adolescência consiste "em um segundo nascimento, doloroso, gerador de tensões emocionais e desequilíbrios psicológicos".

Com o passar dos anos, cai por terra o entendimento de que apenas os fatores biológicos são responsáveis pelos transtornos da vida mental e afetiva, observados na fase da adolescência. Souza-Leite (2008) cita Stanley Hall, e atribui a ele a autoria do primeiro compendio sobre a adolescência, publicado em 1904. Segundo Souza-Leite (2008), Hall define a adolescência como uma fase caracterizada por perturbações de conduta, período de tensão e tormenta. Hall teria sido o pioneiro a afirmar que puberdade e adolescência não são sinônimas e que muitas das variações comportamentais na juventude têm origem a partir de uma crise de identidade que passa pelo processo de conscientização de si mesmo.

Outra importante contribuição para as concepções contemporâneas sobre a adolescência decorre de Piaget (1971a; 1971b; 1976). Segundo Souza-Leite (2008), este autor definiu a adolescência em suas obras como um período de desenvolvimento que se reestrutura as capacidades cognitivas do ser. O potencial de reflexão que surge na adolescência tem papel fundamental na descoberta do eu, no desenvolvimento moral e na formação da identidade.

Para Levisky (1998) a adolescência consiste em um processo que ocorre durante o desenvolvimento evolutivo de cada indivíduo, que será caracterizado pelas transformações biológicas, psicológicas e sociais. Assim, compreende-se que a cultura e a sociedade na qual o indivíduo está inserido, serão os fatores determinantes nas características psicológicas, na expressividade e manifestações de comportamento.

Souza-Leite (2008) defende a ideia de que a adolescência é um período de crise e turbulência, tanto de crescimento quanto de adaptação a uma nova idade. Essa adaptação passa pelos desafios que o adolescente tem que enfrentar diante das mudanças fisiológicas, o adeus à infância, o convívio com o corpo novo, a nova aparência, as novas maneiras de encarar a vida e responsabilidades. Ainda para a autora, essa transição enfrentada faz parte da meta social do adolescente, ou seja, converte-se em um adulto.

Aberastury (1990), considerada a pioneira no estudo da psicanálise de crianças e adolescentes na América Latina, traz a concepção que 
[...] a adolescência é um momento crucial na vida do homem e constitui a etapa decisiva de um processo de desprendimento. Esse processo atravessa três momentos fundamentais: o primeiro é o nascimento, o segundo surge ao final do primeiro ano com a eclosão da genitalidade, a dentição, a linguagem, a posição de pé e a marcha; o terceiro momento aparece na adolescência. (ABERASTURY,1990, p. $15)$.

Levisky (1998) citando Aberastury e Knobel (1971) identifica o que estes autores chamaram de "síndrome normal da adolescência" que tem como principais características: a busca de si mesmo e da identidade; tendência grupal; necessidade de intelectualizar e fantasiar; crises religiosas que podem ir desde o ateísmo até o misticismo mais fervoroso; desorientação temporal quando o pensamento adquire as características de pensamento primário; evolução sexual manifesta; atitude social reivindicatória, com tendências anti ou associas de diversas intensidades; contradições excessivas em todas as manifestações da conduta, dominadas pela ação, que constitui a forma de expressão conceitual mais típica desse período da vida; uma separação progressiva dos pais e contraentes flutuações do humor e do estado de ânimo.

E, quanto ao adolescente propriamente dito? Este se redefine na fase da adolescência como pessoa, revive conscientemente (ou não) situações afetivas de sua infância, tornando seu equilíbrio emocional instável e suas emoções oscilantes. Destarte, o adolescente terá que elaborar três lutos nessa etapa: o luto pelo corpo infantil, pela identidade e papéis infantis e por fim, o luto pelos pais da infância. (ABERASTURY, 1991; LEVISKY 1998; LEVISKY, 2000; SOUZA-LEITE, 2008).

Para Souza-Leite (2008),

[...] diante desses lutos, nascem os conflitos e, consequentemente, as respostas frente a esses conflitos. De qualquer maneira, o jovem demonstra seu desconforto por meio de seu comportamento, muitas vezes classificados como radical, ou por meio de sua impulsividade, sexual ou agressiva (SOUZA-LEITE, 2008, p. 70).

Por estes vieses é possível aferir algumas reflexões sobre o adolescente e sua proximidade com a violência, bem como o adolescente e a prática de atos infracionais. Constantemente, ou quase que diariamente, a mídia retrata atos de violência e criminalidade contra jovens e/ou infrações cometidas por jovens, em uma sociedade que tem sofrido mutações em uma velocidade extremamente rápida.

A violência é um fator humano e social. Por não ser abstrata é um fenômeno que foge de qualquer conceituação precisa. De acordo com Zaluar (1999) umas das 
dificuldades na definição do que é violência decorre do fato do próprio termo ser polifônico, desde sua etimologia. Do latim, violentia, remete a força, vis, vigor, emprego de força física ou com recursos. Para essa autora, torna-se violência "quando ultrapassa um limite ou perturba acordos tácitos e regras que ordenam relações, adquirindo carga negativa ou maléfica" (ZALUAR, 1999, p.8). O ato só será caracterizado como violento mediante a percepção do limite e do sofrimento que provoca, o que também está associado a cada cultura e momento histórico.

A Organização Mundial da Saúde - OMS, no ano de 2002 se pronunciou em relação à violência de forma mais contundente, divulgando o Relatório Mundial sobre violência e saúde, na qual definiu o problema da violência como

[...] uso intencional da força física ou do poder real ou em ameaça, contra si próprio, contra outra pessoa, ou contra um grupo ou uma comunidade, que resulte ou tenha qualquer possibilidade de resultar em lesão, morte, dano psicológico, deficiência de desenvolvimento ou privação (KRUG et al., 2002, p. 5).

Outro importante conceito que precisa ser delimitado é o da violência criminal. Na visão de Kathie (2009), consiste na prática de agressão grave à pessoa, por atentado à sua vida e/ou bens, tendo como requisito a constituição de objeto de prevenção e repressão por parte da Justiça e dos órgãos de segurança pública.

Conforme já exposto, independente das várias nuances e particularidades culturais e históricas que existem na fase da adolescência, pode-se considerar que este período é extremamente importante e especial no desenvolvimento humano, na construção da identidade, da imagem de si e no desenvolvimento das competências cognitivas. Toda esta conjuntura também pode estar vulnerável à violência juvenil, estando o adolescente como autor e/ou vítima.

Antes da promulgação do Estatuto da Criança e do Adolescente - ECA, os diagnósticos e as pesquisas sociológicas, no campo da delinquência juvenil, tratavam os adolescentes envolvidos com ilicitudes, com termos e nomenclaturas estigmatizantes e com teor pejorativo, referindo-se a eles como infratores, pivetes, "de menor", trombadinhas, etc. Com o ECA, o adolescente, neste contexto, passa a ser denominado de ator de ato infracional ou adolescente em conflito com a lei, assegurando assim a prerrogativa de sujeito pleno de direitos.

De acordo com Naves e Gazoni (2010) a lei quer distanciar a aplicação simples do conceito comum de crime ou contravenção penal utilizado pelo Direito Penal, por 
considerar que não atende as características e necessidades inerentes a fase da infância e da adolescência. Por este motivo, os comportamentos ilícitos praticados pela população infanto-juvenil são descritos como Ato Infracional, no artigo 103 do ECA e não crime ou contravenção. (BRASIL, 2016).

Fica evidente também que o ECA pretende romper com o martírio imposto pelo senso comum que desqualifica o adolescente, ator de ato infracional. Este mesmo senso comum, na visão de Volpi (2015), atribui à Segurança a "fórmula mágica" na proteção da sociedade e de seu patrimônio, contra a violência produzida pelos "desajustados sociais", defendendo com veemência a necessidade do afastamento do convívio social e o caloroso discurso da maioridade penal.

Para Volpi (2015, p. 12),

[...] neste contexto de indefinições crescem os preconceitos e alastram-se explicações simplistas, ficando a sociedade exposta a um amontoado de informações desencontradas e desconexas usadas para justificar o que no fundo não passa de uma estratégia de criminalização da pobreza, especialmente dos pobres de raça negra.

Os debates em torno da redução da maioridade Penal são calorosos, dividem opiniões e suscitam divergências entre parlamentares, juristas, intelectuais e na sociedade de modo geral. Atos infracionais, tanto protagonizados por adolescentes, ou na condição de vítimas, têm uma visibilidade maior que os demais e costumam gerar grande comoção e indignação na população brasileira. Contudo, o debate vazio e elaborado no calor dos acontecimentos não é capaz de sanar os problemas. Antes de tudo, deve-se recorrer ao nosso ordenamento jurídico e aos trabalhos científicos em andamento e verificar se há ou não argumentos que justifiquem alterar a norma em vigência.

Atualmente, encontra-se em tramitação no Congresso Nacional, na Comissão de Constituição e Justiça e Cidadania - CCJC, quase 40 Propostas de Emenda à Constituição - PEC que versam sobre a redução da maioridade penal. $\mathrm{O}$ primeiro foi o PEC no $171 / 1993^{9}$, cujo signatário é o ex-deputado Benedito Domingos que busca

\footnotetext{
${ }^{9}$ As Propostas de Emenda Constitucional que alteram o artigo 228 da Constituição Federal para reduzia a maioridade penal de 18 anos de idade para 16 anos, em apenso ao PEC 171/1993, são: PEC's n ${ }^{\circ}$ s 386/1996, 426/1996, 242/2004, 37/1995, 91/1995, da 301/1996, 531/1997, 68/1999, 133/1999, 150/1999, 167/1999, 169/1999, 633/1999, 260/2000, 321/2001, 377/2001, 582/2002, 64/2003, 179/2003, 272/2004, 302/2004, 345/2004, 489/2005, 48/2007, 73/2007, 85/2007, 87/2007, 125/2007, 399/2009, 57/2011, 223/2012 e 228/2012, 273/2013, 279/2013, 332/2013, 349/2013, 382/2014 e 438/2014. Informações disponíveis em <http://www.camara.gov.br/proposicoesWeb/fichadetramitacao?idProposicao=14493>. Acesso em: 25 de julho de 2017.
} 
alterar o artigo 228 da Constituição da República, com a finalidade de reduzir a idade mínima prevista para a responsabilização penal, atualmente fixada em 18 anos.

A Norma vigente no Brasil estabelece que seja penalmente inimputável ${ }^{10}$ os menores de dezoito anos, sujeitos às normas da legislação especial. Essa norma encontra-se inscrita em três dispositivos legais: artigo 27 do Código Penal; Artigo 104, caput, do Estatuto da Criança e do Adolescente e no Artigo 228, da Constituição Federal. (BRASIL, 1984; BRASIL, 2008; BRASIL, 2016).

Para Oliveira (2015) a redução da maioridade penal, na visão de alguns parlamentares, tem sido discutida como uma política de segurança pública. Segundo eles a redução da maioridade penal contribuirá para uma melhoria da segurança, visto que diminuirá as práticas de violência na sociedade, entre elas os homicídios, e, supostamente, entre os adolescentes de 16 e 17 anos que seriam os responsáveis pelos altos índices de criminalidade registrados.

Ainda no entendimento de Oliveira (2015) a proposta da redução da maioridade penal é completamente equivocada, pois fere princípios constitucionais, que vetam toda e qualquer forma de eliminar direitos sociais. Além disso, os argumentos não devem ser vistos como uma política de segurança, pois “quem deseja mais segurança deve pensar mais amplamente nos dados que antecedem os problemas e nos possíveis desdobramentos das políticas propostas”. (OLIVEIRA, 2015, p.4).

Endossando esta discussão, Argolo (2007, p.3) relata que “em pesquisas realizadas por organismos internacionais, as estatísticas revelaram que mais da metade da população mundial tem sua maioridade penal fixada em 18 anos de idade". Este mesmo autor cita também a pesquisa Crime Trends (Tendências do Crime), feita a cada quatro anos pela Organização das Nações Unidas - ONU, que apontou, em sua última versão, que os países que para fins penais, consideram como adultos a pessoa com

\footnotetext{
${ }^{10} \mathrm{~A}$ inimputabilidade pode ser compreendida como algo ou alguém que não se pode imputar. Imputar é o mesmo que atribuir a alguém a responsabilidade de algo censurável (crime). O princípio da inimputabilidade absoluta dos menores de 18 anos de idade está consagrado no Código Penal, em seu artigo 27: "os menores de 18 anos são penalmente inimputáveis, ficando sujeitos às normas estabelecidas na legislação especial” (BRASIL, 1984, p.1). Para Naves e Gazoni (2010, p. 201), a criança e o adolescente praticam ato infracional e não crime ou contravenção, pois o desenvolvimento incompleto que caracteriza as primeiras fases da vida não é compatível com a imputabilidade penal. Ainda para estes autores, citando o Código Penal Brasileiro, o crime vem especificado pela relação de causalidade com a produção de um resultado definido no ordenamento jurídico como crime. $\mathrm{O}$ crime pode ser classificado como consumado quando se reúnem todos os elementos de sua concepção legal e pode ser classificado como tentado, quando iniciada a execução, não se consuma por motivos alheios à vontade do agente. Estes conceitos só podem ser atribuídos aos maiores de 18 anos de idade.
} 
menos de 18 anos de idade são os que apresentam baixo Índice de Desenvolvimento Humano (IDH), com exceção dos Estados Unidos e Inglaterra.

Oliveira (2015) destaca ainda que, dos vários desdobramentos sobre a redução da maioridade penal no Brasil, há indícios de que um destes aumentaria o número de mortes violentas - homicídio, mortes no trânsito e suicídio. Isso pode ser compreendido com o direito de dirigir que seria estendido aos adolescentes de 16 e 17 anos de idade e a compra de bebidas alcoólicas permitidas. É enfático ao ratificar que "reduzir a maioridade penal, além de produzir mais violência (via consumo de álcool) e mais mortes violentas (via acidentes de trânsito), não nos dará uma sociedade melhor" (OLIVEIRA, 2015, p.4).

Neste trabalho, o posicionamento que se defende quanto à redução da maioridade penal está em consonância com o discurso de profissionais de diversas áreas, especializados no atendimento de crianças e adolescentes que são contrários a redução da maioridade penal. O que precisa ser proporcionado aos adolescentes em conflito com a lei é um trabalho de educação e (re)socialização que lhe ofereça com segurança, autonomia, oportunidades reais e apoio para a realização de novos projetos de vida, com políticas que, de fato, asseguram o ingresso, a manutenção e a permanência na sociedade, com oportunidades de formação, qualificação, trabalho e bem estar.

A complexidade do ato infracional precisa ser compreendida sob o prisma dos vários componentes que colaboram para o ingresso dos adolescentes, pois não é um fenômeno isolado e não é atribuição apenas de um fator. Além das principais características inerentes a fase da adolescência, já expostas, a Organização Mundial de Saúde organizou os principais fatores, em diversos níveis, que aumentam a vulnerabilidade para a prática de ato infracional, sendo eles: individual, relacional, comunitário e social (KRUG, 2002).

Segundo a OMS, no fator individual, levam-se em conta as características biológicas, tais como ter danos neurológicos sutis; características psicológicas como impulsividade, hiperatividade, precário controle diante de frustrações, deficiência de atenção e incapacidade de planejamento e fixação de metas. No relacional, têm-se como características os maus-tratos familiares; o indivíduo que passa a infância em família com grandes conflitos e vínculos afetivos deficientes; os que possuem família mono 
parental; que não contam com suporte social comunitário e os que sofrem influência de amigos 'delinquentes' (KRUG, 2002).

Ainda de acordo com a OMS, o fator comunitário aumenta a vulnerabilidade para a prática de ato infracional quando na comunidade há altos índices de criminalidade, existência de gangues, drogas e armas de fogo e comunidades que possuam baixo capital social. No fator social destacam-se as mudanças sócio demográficas não planejadas como imigração e urbanização desordenada, desigualdade de renda, insatisfação com o governo e com a atuação da polícia (ostensiva e repressiva), normas culturais que apontem a violência como forma de resolver conflitos e diferenças (KRUG, 2002).

O Ministério dos Direitos Humanos - MDH, por meio da Secretaria Nacional dos Direitos da Criança e do Adolescente - SNDCA, divulgou no ano de 2017 o Levantamento Anual Sinase 2014. Este levantamento do Sistema Nacional de Atendimento Socioeducativo apresentou a sistematização dos dados enviados pelos órgãos gestores do SINASE em âmbito estadual à Coordenação-Geral do SINASE da SNDCA órgão do Ministério dos Direitos Humanos. Os dados sistematizados se referem à situação do atendimento em 30/11/2014.

Os referidos dados do Levantamento Anual referentes ao ano de 2014 indicaram um número total de 24.628 adolescentes e jovens (12 a $21 \operatorname{anos}^{11}$ ) em restrição e privação de liberdade (internação, internação provisória e semiliberdade) na data de 30 de novembro de 2014, considerando-se ainda 800 adolescentes em outras modalidades de atendimento (atendimento inicial, sanção e medida protetiva).

O Levantamento utilizou a projeção da população do Brasil, disponibilizada pelo Instituto Brasileiro de Geografia e Estatística - IBGE, sendo a população total no país em 2014 de 202.768.562, para aferir a população adolescente (12 a 18 anos de idade) que correspondeu a 24.042.852. Destarte, a medida de privação de liberdade e restrição de liberdade representou $0,1 \%$ dos adolescentes dentre a população de 12 a 18 anos no país.

O trabalho revelou em números, a variação anual da restrição e privação de liberdade, referentes a internação -foco desta pesquisa, internação provisória e

${ }^{11} \mathrm{O}$ Artigo $2^{\circ}$ do Estatuto da Criança e do Adolescente - ECA (Lei Federal no 8069/1990), estabelece que a idade dos adolescentes é entre 12 e 18 anos incompletos. O Parágrafo Único do Título I indica que nos casos de excepcionalidade, como o atendimento socioeducativo, o ECA será aplicado entre 18 e 21 anos de idade. (BRASIL, 2016). 
semiliberdade, entre os anos de 2008 - 2014. No ano de 2008 os números correspondiam a 16.868 adolescentes e, em 2009, passou a ser 16.940, representando um aumento de 0,4\%. Em 2010 ocorreu um aumento de 4,5\% passando assim para 17.703 adolescentes e em 2011 com a quantidade de 19.595 adolescentes ocorre o primeiro aumento significativo de 10,5\%. No ano de 2012 os 20.532 representaram um aumento menor com relação ao ano anterior de apenas 4,7\%, o segundo aumento significativo ocorreu em 2013 com 23.066 adolescentes que representaram um aumento de $12 \%$ resultante do crescimento da modalidade de atendimento em semiliberdade no país que tinha voltado a crescer, porém em 2014 decresceu de 2.272 para 2.173 adolescentes, enquanto a internação teve crescimento de 15.221 (em 2013) para 16.902, totalizando assim no ano de 2014, 24.628 adolescentes (aumento de 6\%) (BRASIL, 2017).

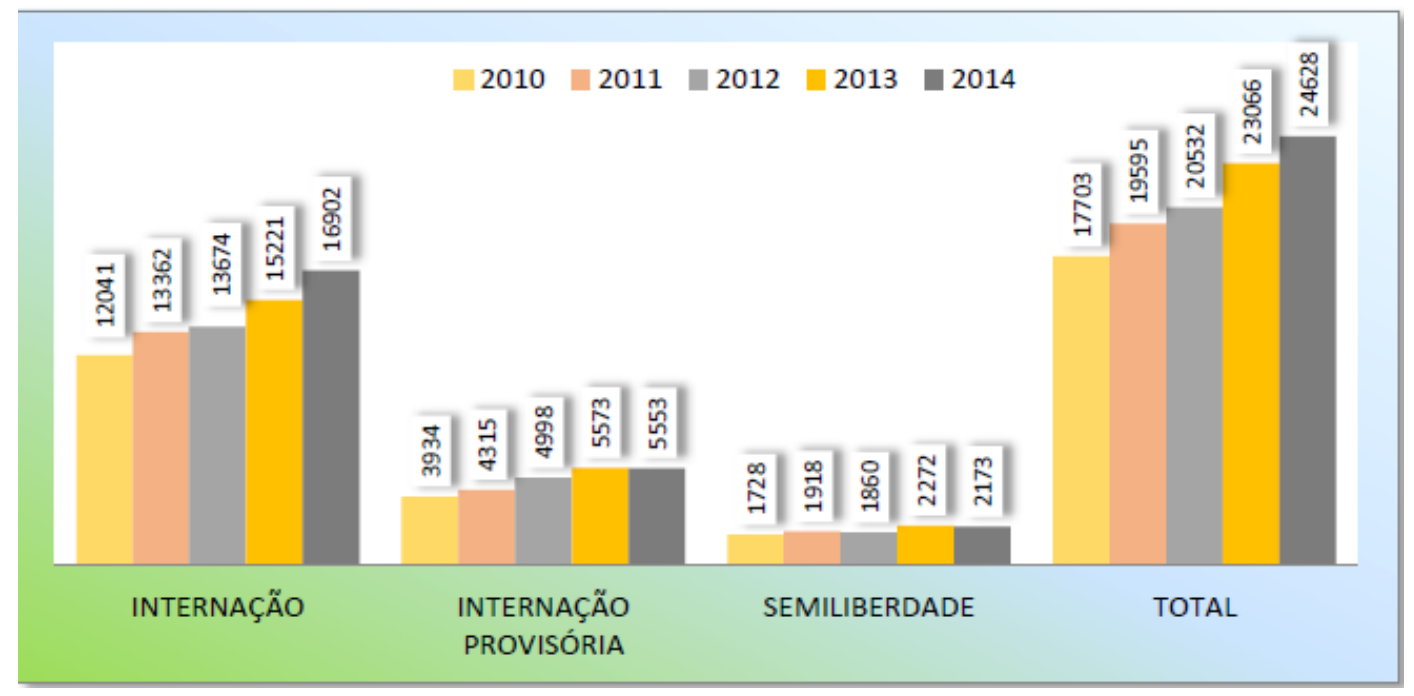

FIGURA 01: Adolescentes e Jovens em Restrição e Privação de Liberdade - Total Brasil (2010-2014)

Fonte: Levantamento Anual Sinase 2014 (BRASIL, 2017).

Em 2014, dos 24.628 adolescentes e jovens brasileiros em restrição e privação de liberdade, $66 \%$ cumpriram medida socioeducativa de internação, seguido de $22 \%$ na internação provisória, 9\% na semiliberdade e 3\% na categoria 'Outros' (atendimento inicial, internação sanção e medida protetiva) (BRASIL, 2017).

No que tange ao ato infracional, em 2014 foram registrados 26.913, protagonizados por 25.428 adolescentes em restrição e privação de liberdade em todo Brasil. O número de atos infracionais é superior ao de adolescentes e jovens em 
decorrência da possibilidade de atribuir mais de um ato a uma mesma sentença que estabeleceu a medida socioeducativa. Do total de atos infracionais, destacam-se os classificados como análogo a roubo, ao tráfico de drogas, ao homicídio e ao furto, correspondendo respectivamente, 44\%, 24\%, 9\% e 3,30\% (BRASIL, 2017).

A distribuição entre as Unidades da Federação revelou o Estado de São Paulo com Sistema Socioeducativo acima de dois mil adolescentes, 11 Estados e Distrito Federal com Sistema Socioeducativo entre 501 a 2.000 adolescentes e jovens (MG, RJ, PE, RS, DF, PR, ES, CE, BA, PB, AC), 07 Estados entre 201 e 500 adolescentes (GO, PA, SC, MS, RO, AL, AP) e 6 Estados com menos que 200 adolescentes (MA, RN, SE, TO, PI, MT, AM, RR) (BRASIL, 2017).

Levantamento Anual SINASE 2014, indicou que 16 Unidades da Federação e o Distrito Federal tiveram um aumento na restrição e privação de liberdade. Enquanto que 11 Unidades da Federação apresentaram diminuição do número de adolescentes e jovens em restrição e privação de liberdade. Os estados que registraram maior concentração de atos infracionais foram: São Paulo (10.211), Pernambuco (1.892), Minas Gerais (1.853), Rio de Janeiro (1.655), Rio Grande do Sul (1.192) e o Distrito Federal (1.084) (BRASIL, 2017).

O perfil e as características dos adolescentes e jovens em restrição e privação de liberdade expõem claramente a situação de desigualdade a que estão sujeitos desde o nascimento. Em relação ao número total em 2014, 95\% (23.447) são adolescentes e jovens do sexo masculino e 5\% (1.181) do sexo feminino. O Levantamento revelou um aumento de $4 \%$ para $5 \%$ da participação feminina no total dos atendimentos socioeducativos de 2013 para 2014 (BRASIL, 2017).

No que tange à faixa etária dos adolescentes e jovens em restrição e privação de liberdade, os dados referentes a 2014 revelaram que a maior proporção dos adolescentes está concentrada na faixa etária entre 16 e 17 anos com 56\% (13.867), seguida pela faixa etária 18 a 21 anos com 24\%, entre 14 a 15 anos com $18 \%$ e 12 a 13 anos com 2\% (BRASIL, 2017). O gráfico a seguir ilustra os dados apresentados. 


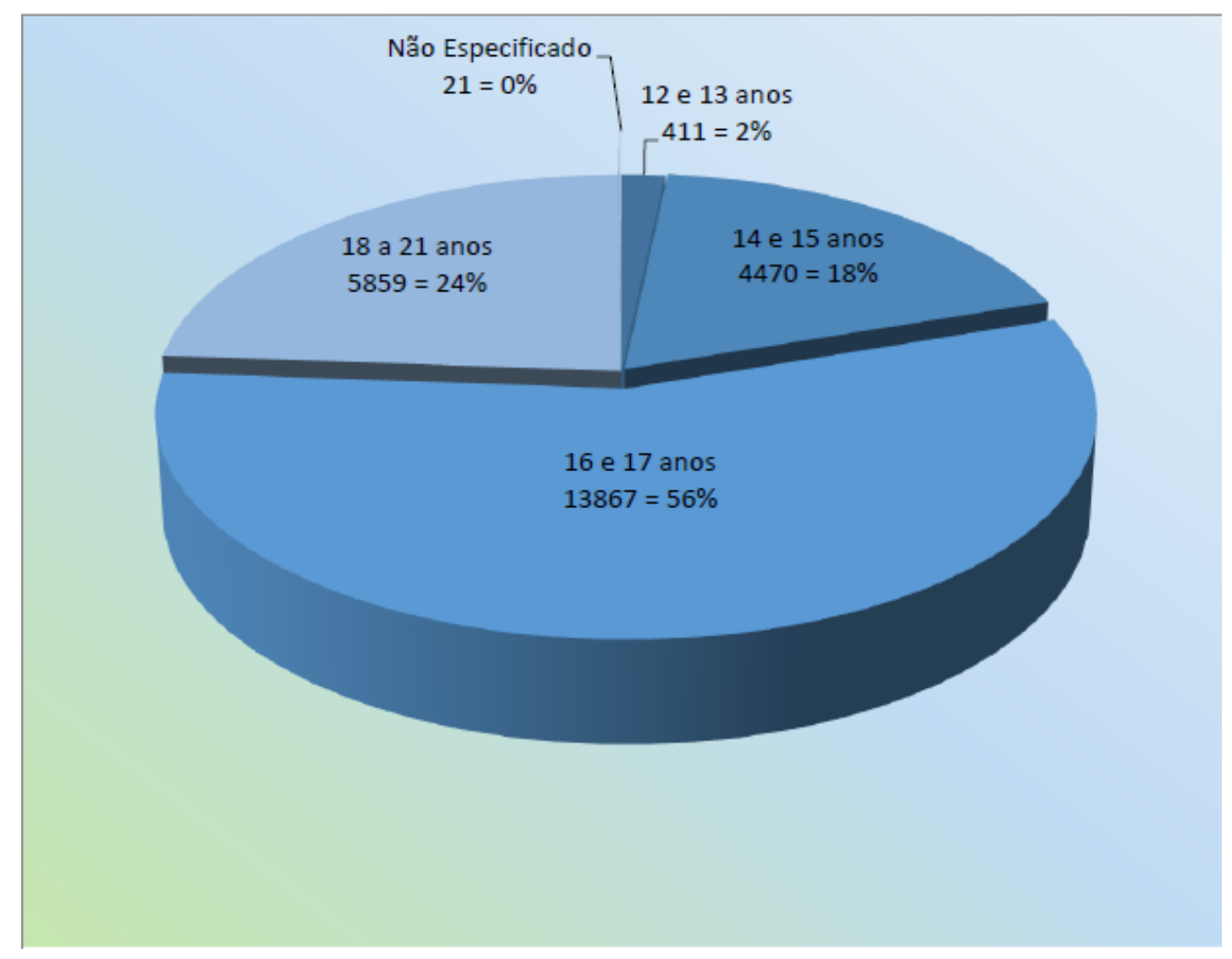

FIGURA 02: Adolescentes e Jovens por Faixa Etária em Restrição e Privação de Liberdade - Total Brasil (2014)

Fonte: Levantamento Anual Sinase 2014 (BRASIL, 2017).

Outro dado significativo e que traduz um pouco do perfil da sociedade brasileira é a porcentagem de adolescentes e jovens por raça e cor, em restrição e privação de liberdade. A partir das categorias de classificação de cor e raça utilizadas pelo IBGE, o Levantamento Anual SINASE 2014 trouxe a lume que 56\% dos adolescentes e jovens em restrição e privação de liberdade foram considerados pardos/negros, $21 \%$ de cor branca e $1 \%$ de cor amarela. O Levantamento salientou que $22 \%$ dos adolescentes não tiveram registro quanto a sua cor, sendo classificados na categoria "sem informação" (BRASIL, 2017). 


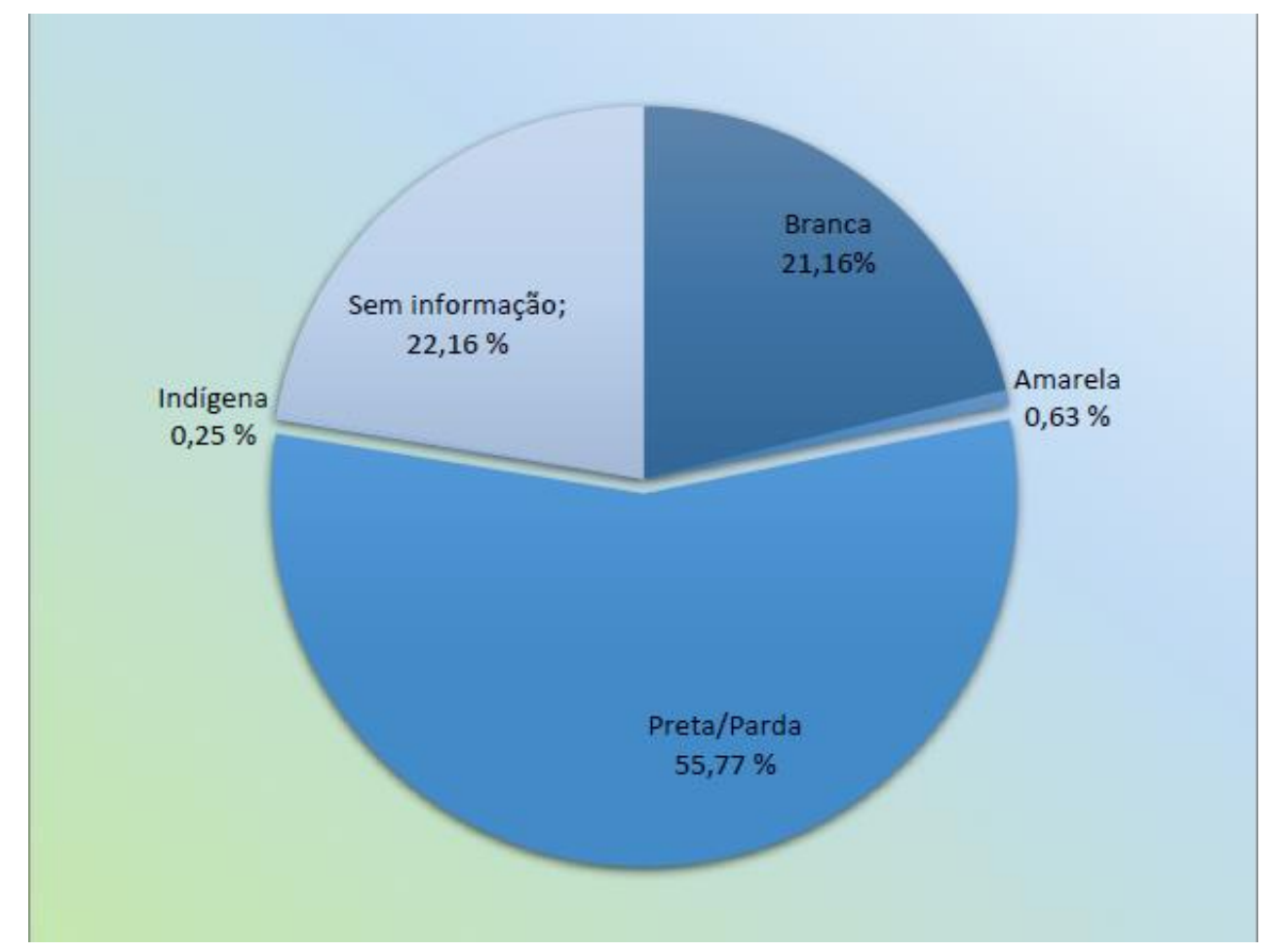

Figura 03: Porcentagem de Adolescentes e Jovens por Raça/cor em Restrição e Privação de Liberdade - Total Brasil (2014)

Fonte: Levantamento Anual Sinase 2014 (BRASIL, 2017).

Estes dados reforçam a ideia defendida neste trabalho quanto a complexidade do ato infracional, dos reais mecanismos e fatores de atração e como precisa ser compreendida sob o prisma dos vários componentes que colaboram para o ingresso dos adolescentes as práticas infracionais, pois não é um fenômeno isolado.

Estes dados também endossam o discurso de fortalecer as políticas de atendimento socioeducativo no Brasil, com uma proposta humanizadora, cidadã e socializadora. De acordo com Sherman (1997 apud BRASIL, 2005), estudos revelam que um atendimento articulado em estratégias punitivas tem impacto limitado na prevenção da violência, podendo até mesmo fomentar para o seu aumento.

Os novos valores agregados ou reeditados à sociedade, que chegam em uma velocidade rápida, geram insegurança e instabilidade e contribuem para descargas impulsivas, as quais passam a integrar os cotidianos das pessoas (LEVISKY, 2000). Os parâmetros que direcionam os hábitos, normas e costumes, descritos nos códigos de ética, sob a ótica de Levisky (2000), sofrem uma brusca transformação que vai além da capacidade perceptiva, reflexiva, o senso crítico e a repressão eficaz dos impulsos desejáveis para a vida em sociedade. 
Isso põe em debate os destinos dos adolescentes, no tempo presente, diante de uma sociedade na qual o elemento violência, entendido aqui em suas diferentes formas de expressão, está intrínseco nos modelos que identificam os padrões de conduta e autoafirmação. No processo de identidade do adolescente, a autoafirmação é um componente necessário e desejável (LEVISKY, 2000).

Aqui reside a importância da incorporação de políticas públicas eficientes para a

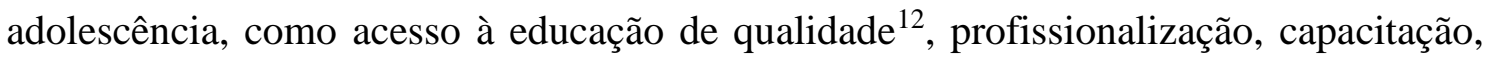
cultura, lazer, entre outras, e, acima de tudo, valores a serem trabalhados, adequados a uma relação construtiva da sociedade. O processo de identificação do adolescente ocorre com a relação entre os pais, numa interação com a instituição familiar e com a sociedade (LEVISKY, 2000), sendo este processo determinado pelos valores culturais vigentes. Eis aqui um dos grandes desafios da sociedade contemporânea que reside na realização do potencial dessas novas gerações.

\footnotetext{
12 Neste trabalho entende-se por educação de qualidade aquela que possibilite ao adolescente se identificar como cidadão e lhe ofereça pleno acesso e compreensão aos métodos de ensino e aos conhecimentos proporcionados, despertando o senso crítico e ético. Além disso, garanta a cada pessoa oportunidades reais de progresso, dentro do contexto social, econômico e político vigente. A educação de qualidade não necessita apenas de professores capacitados e uma boa estrutura física e didática. É preciso que haja uma mobilização da sociedade para o importante papel que a Educação possui na vida de todos, valorização dos profissionais que atuam nesta área, maior direcionamento de recursos financeiros para as instituições escolares e professores, entre outras.
} 


\section{CAPÍTULO 02}

\section{UM NOVO MARCO NA HISTÓRIA DA CIDADANIA BRASILEIRA - O ESTATUTO DA CRIANÇA E DO ADOLESCENTE}

O objetivo deste capítulo é apresentar ao leitor os princípios norteadores que deram origem a promulgação da Lei 8.069/90, conhecida como o Estatuto da Criança e do Adolescente. Por ser tratar de um marco na história da cidadania brasileira é imprescindível que se compreenda quais os princípios defendidos por essa Lei, os mais relevantes desafios e os avanços alcançados nos seus 27 anos de existência. Ainda neste texto, no intuito de auxiliar na compreensão do que se propõe o objetivo geral, será feita uma descrição sobre as medidas protetivas e as medidas socioeducativas, previstas no texto legal, com um tópico especifico para a medida socioeducativa de internação única trabalhada nesta pesquisa.

Por fim, este capítulo apresenta a Lei 12.594/12, marco normativo que institui o Sistema Nacional de Atendimento Socioeducativo - Sinase em todo território nacional, destacando os pontos mais relevantes como o eixo escolarização na medida socioeducativa de internação.

\subsection{Origem, princípios, avanços e desafios do ECA}

Como já exposto no capítulo anterior a trajetória institucional da política da criança e do adolescente no Brasil passou por diferentes arranjos ao longo dos anos. Mesmo com a participação da sociedade civil na assistência à infância, principalmente a desvalida, a atuação em várias décadas foi quase sempre marcada pela falta de recursos financeiros regulares e contínuos. (ROCHA, 2016).

As políticas públicas destinadas a infância saem da chamada Doutrina de Situação Irregular para a Doutrina de Proteção Integral, o que resultou nesta transição a criação do Estatuto da Criança e Adolescente, com a promulgação da Lei 8069/1990. Antes de expormos as principais características, elementos e objetivos do ECA é interessante elucidar ao leitor o que de fato foi essa ruptura nas referidas Doutrinas.

Na primeira, amparada pelo antigo Código de Menores (Lei 6.697/1979), os adolescentes em conflito com a lei não eram tratados como sujeitos de direitos e sim 
como objetos de medidas judiciais. O menor em situação irregular era definido, conforme o artigo $2^{\circ}$, como aquele "privado de condições essenciais a sua subsistência, saúde, instrução obrigatória; em perigo moral; privado de representação ou assistência legal pela falta eventual dos pais ou responsáveis; com desvio de conduta; respondendo por prática infracional (...)" (BRASIL, 1979, p.01).

No entendimento de Veronese e Custódio (2011) no que tange ao menor em irregular situação, ele

[...] foi caracterizado pela determinação de um modelo que colocava a criança em patamar de um incapaz, onde era estabelecida uma prática repressiva, autoritária e não participativa orientada pela centralização das políticas do governo. Seu gerenciamento era efetuado pelo Poder Judiciário com mão de ferro, auxiliado pelas práticas policiais de caráter mais violento, apenas pelo fato do menor ser pobre e carecer das condições básicas de subsistência para exercer seus direitos humanos com dignidade, que todo menor deveria possuir (VERONESE; CUSTÓDIO, 2011, p. 26).

Isso se justifica, entre várias características, pela crescente e acentuada desigualdade que o país viveu já no início do século XX. Assim, os “menores" - termo pejorativo usado na época e que ainda persiste em muitos discursos atuais, se sujeitavam aos delitos e práticas análogas ao crime para sustento próprio e da família. Estes deveriam ser abrigados em instituições e entidades de assistência social apropriadas para suas condutas, de acordo com as diretrizes do Novo Código, sendo as FEBEM's um exemplo destes locais. (ROCHA, 2016). Todas essas políticas deixaram evidente que a preocupação do Estado não era de proteger os "menores" e sim garantir a ordem, ou qualquer outro risco material ou moral.

A Doutrina de Proteção Integral estabelece na história do país um marco de significativo e expressivo avanço nas causas que militam em prol da criança e do adolescente e mais que isso, contribuiu para a origem do Estatuto da Criança e do Adolescente - ECA. Para entendermos esse processo devemos retornar a década de 1970, que, segundo ROCHA (2016), surgem, neste período, movimentos sociais que trazem a discussão uma nova visão sobre crianças e adolescentes e alertavam sobre as atrocidades e a ineficácia da prática de confinamento em instituições, destinadas a elas, comumente usadas, conforme já apresentado neste trabalho no capítulo 01.

RIZZINI (2001), no mesmo entendimento, destaca que na década de 1980, o processo denominado de redemocratização do país, aliado as pressões dos segmentos internacionais e nacionais, provocou uma mudança do olhar sobre as crianças e 
adolescentes que, conforme os registros históricos, eram vistos como menores abandonados e delinquentes.

Veronese e Custódio (2011) ratificam o que foi exposto ao dizer que

[...] a edificação do modelo realizado pelas doutrinas antigas e ultrapassadas da situação irregular ocasionou, na década de 1980, uma grande resistência aos conceitos que então vigoravam, ao mesmo tempo em que o país passava pelo avanço dos movimentos socioeducacionais. Desse modo, muitos seguimentos iniciaram suas transformações, visto que não era mais aceitável a utilização das velhas doutrinas. Era o princípio de um intrincado processo de mudança que deflagraria na substituição do direito do menor para o então direito da criança e do adolescente, e assim, na consequente permuta da doutrina da situação irregular do menor para a da proteção integral (VERONESE; CUSTÓDIO, 2011, p. 28).

Esse intricado processo de mudança é fruto da redemocratização do país, com a promulgação da Constituição Federal de 1988 (BRASIL, 1988) especificamente com o texto trazido em seu artigo $227^{13}$ e também da Convenção sobre os Direitos da Criança e do Adolescente, da Assembleia Geral das Nações Unidas - ONU, em 20 de novembro de 1989. De acordo com o portal UNICEF - Brasil ${ }^{14}$, essa Convenção pode ser considerada como o instrumento de direitos humanos mais aceito na história do mundo e juntamente com o Brasil, outros 195 países são signatários desta lei.

Isto posto, em substituição ao Código de Menores de 1979 é promulgado em 13 de julho de 1990 a Lei 8.069, conhecida como o Estatuto da Criança e do Adolescente. Agora, a nova política vincula a criança e adolescente, dentre outros preceitos, à condição de sujeito de direitos e garantias fundamentais em condição singular de desenvolvimento. Tentou-se com o ECA garantir "todas as oportunidades e facilidades para as crianças e adolescentes, a fim de lhes facultar o desenvolvimento físico, mental, moral, espiritual e social, em condições de liberdade e dignidade” (BRASIL, 2016, p. 11). Atribui também o status de direito social, ao ratificar no ECA, no artigo $4^{\circ}$ que é dever, expressamente nesta ordem, da família, da comunidade, da sociedade em geral e do poder público garantir a efetivação de todos os direitos conquistados. (ROCHA, 2016).

\footnotetext{
13 Artigo 227 da CF/88 "É dever da família, da sociedade e do Estado assegurar à criança, ao adolescente e ao jovem, com absoluta prioridade, o direito à vida, à saúde, à alimentação, à educação, ao lazer, à profissionalização, à cultura, à dignidade, ao respeito, à liberdade e à convivência familiar e comunitária, além de colocá-los a salvo de toda forma de negligência, discriminação, exploração, violência, crueldade e opressão". (BRASIL, 1988).

${ }^{14}$ Disponível em https://www.unicef.org
} 
Os princípios na elaboração do ECA decorrem da Constituição de 1988. Antes, é importante compreender o conceito de princípio dentro do ordenamento jurídico brasileiro. De acordo com Reale (1991, p. 300) "princípios são certos enunciados lógicos admitidos como condição ou base de validade das demais asserções que compõem dado campo do saber”. Siqueira Junior ratifica ao dizer que “(...) os princípios exercem função importantíssima dentro do ordenamento jurídico-positivo, já que orientam, condicionam e iluminam a interpretação das normas jurídicas em geral, aí incluídos os próprios mandamentos constitucionais" (SIQUEIRA JÚNIOR, 2004, p.161-162).

Rocha (2016) assegura que estes princípios estão pautados na descentralização político-administrativa e na participação popular na gestão. Sendo assim, entende-se que a garantia da eficiência das políticas de atendimento a crianças e adolescentes passa por um conjunto articulado de ações envolvendo não só a União, mas todos os demais entes (estados e municípios) e também ações não governamentais (participação da sociedade civil). A criação desta rede favorece a municipalização do atendimento; criação de conselhos; criação e manutenção de programas específicos; a integração operacional de órgãos do judiciário, Ministério Público, Defensoria, Segurança Pública e Assistência Social e por fim, de acordo com a referida autora, mobilização da opinião pública para a indispensável participação dos diferentes segmentos da sociedade.

De acordo com o Relatório Avaliativo, publicado pelo Conselho Nacional dos Direitos da Criança e do Adolescente, no ano de 2016, desde de sua promulgação, o ECA, apesar de todos os impasses políticos, apresentou significativos avanços. O texto destacou a redução expressiva da mortalidade infantil no país, que segundo o Ministério da Saúde, entre 1990 e o ano de 2012 a taxa de óbito entre crianças menos de 1 ano de idade caiu $68,4 \%$, o que representa a marca de 14,9 mortes para cada 1.000 nascidos vivos (UNICEF, 2015; ROCHA, 2016).

$\mathrm{Na}$ área da educação, segundo o Relatório, praticamente todos os indicadores foram positivos. Destacou a universalização do acesso à educação obrigatória, que no ano de 2014 teve um percentual de 97,5\% de crianças de 6 a 14 anos, matriculadas no ensino fundamental (PNAD, 2014 ${ }^{15}$ ). Outros avanços correspondem a quase universalização da alfabetização entre jovens de 15 a 17 anos, que chegou a 99,1\%;

\footnotetext{
${ }^{15}$ Pesquisa Nacional por Amostra de Domicílios - 2014. Disponível em < https://ww2.ibge.gov.br>
} 
expressiva redução na taxa média de analfabetismo entre crianças e adolescentes de 10 a 18 anos, que em 1990 correspondia a 12,5\% e em 2013 a 1,4\% (ROCHA, 2016).

Na seara social, o mesmo Relatório apontou uma expressiva redução da extrema pobreza no país, considerando extremamente pobres as pessoas com renda de até $\mathrm{R} \$ 77$, linha oficial do Bolsa Família e base na referência da Nações Unidas para os Objetivos de Desenvolvimento do Milênio (ROCHA, 2016). A pobreza extrema que correspondia a 8\% em 2003 caiu para 2,8\% em 2014 e a redução das taxas ainda foi maior entre crianças de até 5 anos de idade. Para Rocha (2016) todos esses avanços justificam-se pelo

[...] vigoroso sistema de proteção social construído e fortalecido no País nas últimas décadas, com destaque para algumas políticas e medidas de referência, como a estruturação do Sistema Único de Assistência Social, o Programa Bolsa Família, a aprovação do Plano Nacional de Educação (PNE), contendo 20 metas claras e objetivas para o avanço da educação no País; o aumento da cobertura vacinal; o programa Saúde da Família, entre outros. (ROCHA, 2016, p. 12).

Mas é obvio que mesmo diante dos avanços trazidos pelo ECA, há muito ainda a avançar na sua aplicabilidade e são muitos os desafios para que a legislação seja cumprida em todos os aspectos da infância e da adolescência. E isso depende da integração de todos os entes que configuram os princípios da Lei. Cunha (1998) afirma que "[...] todos sabemos que o ECA é o resultado, sobretudo, da incansável luta travada pelos movimentos sociais comprometidos com a democracia e a justiça social" (CUNHA, 1998, p.50).

Entre os principais desafios do ECA, o Relatório Avaliativo, publicado pelo Conselho Nacional dos Direitos da Criança e do Adolescente, no ano de 2016, mostrou ainda que o Brasil possui grandes obstáculos a serem enfrentados dando destaque para a educação e segurança pública. Na educação o desafio maior é assegurar a todos os adolescentes e jovens que estejam estudando concluam a escolaridade básica. (ROCHA, 2016). Os dados da Pesquisa Nacional por Amostra de Domicílio - PNAD ${ }^{16}$, do ano de 2013 revelaram que, dos 10,6 milhões de jovens de 15 a 17 anos, mais de 1 milhão não tinham nenhum vínculo com a escola, ou seja, não estudavam e também não trabalhavam. Nesse mesmo ano e faixa etária, 584 mil só trabalhavam e não estudavam e 1,8 milhão conciliavam os estudos com o trabalho. (PNAD, 2013).

\footnotetext{
${ }^{16}$ Disponível em: https://biblioteca.ibge.gov.br/visualizacao/livros/liv94414.pdf
} 
O Relatório revelou também o avanço nos dados de homicídio de adolescentes, o que chama a atenção para os setores da segurança pública. Os homicídios correspondem a principal causa de morte no Brasil, conforme o Mapa da Violência 2016 (WAISELFISZ, 2016) e os principais alvos são os jovens negros do sexo masculino, moradores de áreas periféricas e metropolitanos dos núcleos urbanos. (ROCHA, 2016). O Mapa da Violência mostrou que na faixa de 15 a 29 anos de idade, o crescimento da letalidade violenta foi bem maior ao comparar com o resto da população e no conjunto da população, o número de homicídios por arma de fogo passou de 6.104, em 1980, para 42.291, em 2014 - crescimento de 592,8\%. Entre os jovens este crescimento foi bem mais expressivo e passou de 3.159 homicídios por arma de fogo, em 1980, para 25.255, em 2014, correspondendo a um crescimento de 699,5\%. (WAISELFISZ, 2016).

Sintetizando os desafios propostos ao ECA, Rocha (2016, p.14) discorre que eles demandam "envolvimento constante por parte do governo e da sociedade, para permitir que as crianças e os adolescentes brasileiros tenham melhoras expressivas em sua qualidade de vida, possibilitando-lhes um futuro melhor". É importante fortalecer cada vez mais as diretrizes, os princípios e as medidas estabelecidas pelo ECA.

\subsection{As Medidas de Proteção e as Medidas Socioeducativas}

As crianças em situação de risco pessoal, social ou cometem algum tipo de ato infracional estão sujeitas a um rol de medidas protetivas, previstas no artigo 101 do Estatuto da Criança e do Adolescente - ECA e os adolescentes, a medidas socioeducativas arroladas no artigo 112 desta legislação específica que ratificam o princípio da Doutrina de Proteção Integral para estes sujeitos. (BRASIL, 2016).

Antes de iniciar a discussão sobre essas medidas é importante fazer aqui uma breve apresentação sobre a Política de Atendimento à Criança e ao Adolescente disposta na parte Especial do ECA, em seu livro II, Título I. Sobre ela, a legislação especial assegura no artigo 86 que será feita através de um conjunto articulado de ações governamentais e não-governamentais, da União, dos Estados, do Distrito Federal e dos municípios. (BRASIL, 2016).

Assim, compreende-se que através de um conjunto de ações integradas da sociedade e do Estado é possível garantir a promoção, a prevenção, a proteção, a defesa e o exercício dos direitos e deveres da criança e do adolescente. Essas ações são 
viabilizadas através de uma variedade de ações específicas de natureza diferente e complementar na área de políticas sociais básicas, serviços de prevenção, assistência supletiva, proteção jurídico-social e defesa dos direitos (BRASIL, 2016).

São linhas de ação da Política de atendimento, elencadas no art. 87 do ECA:

I- $\quad$ Políticas sociais básicas;

II- Políticas e programas de assistência social, em caráter supletivo, para aqueles que deles necessitem;

III- Serviços especializados de prevenção e atendimento médico e psicossocial às vítimas de negligencia, maus-tratos, exploração, abuso, crueldade e opressão;

IV- Serviço de identificação e localização de pais, responsável, criança e adolescente desaparecido;

V- Proteção jurídico-social por entidades de defesa dos direitos da criança e do adolescente;

VI- Políticas e programas destinados a prevenir ou abreviar o período de afastamento do convívio familiar e a garantir o efetivo exercício do direito à convivência familiar de crianças e adolescentes;

VII- Campanhas de estímulo ao acolhimento sob forma de guarda de crianças e adolescentes afastados do convívio familiar e à adoção, especificamente inter-racial, de crianças maiores ou de adolescentes, com necessidades específicas, de saúde ou com deficiência e de grupos de irmãos. (BRASIL, 2016, p. 24).

Impõe-se estabelecer previamente também, juridicamente, à luz do ECA, a distinção entre criança e adolescente, para que didaticamente se possa identificar os indivíduos que estão sujeitos a cada uma das medidas (protetivas e socioeducativas). De acordo com o artigo $2^{\circ}$ dessa legislação especial, considera-se criança a pessoa até 12 anos de idade incompletos, e adolescentes aquela entre doze e dezoito anos (BRASIL, 2016).

Nesse entendimento e dialogando com Bandeira (2006) a responsabilidade juvenil iniciará aos doze anos e se estenderá até os dezoito anos incompletos, de modo que apenas o adolescente, autor de ato infracional a quem for imputada tal prática, estará sujeito à imposição de quaisquer medidas protetivas e/ou socioeducativas, arroladas nos artigos 101 e 112 do ECA, respectivamente.

As medidas protetivas são atribuídas às crianças sempre que os seus direitos forem ameaçados ou violados pela ação ou omissão da sociedade ou do Estado; por falta, omissão ou abuso dos pais ou responsáveis ou em razão de sua conduta (ECA, art. 98). As medidas possuem um cunho educativo, pois em sua aplicação, levam-se em 
conta as necessidades pedagógicas, de preferência as que visem ao fortalecimento dos vínculos familiares. (BRASIL, 2016).

Para Naves e Gazoni (2010) a aplicação de qualquer medida protetiva precisa estar sempre em consonância com os direitos fundamentais da criança e por este motivo, a ideia de "punição" deve ser totalmente abolida. O objetivo é fazer cumprir os direitos da criança por aqueles que os estão violando, sejam eles os pais ou responsáveis, a sociedade ou o Estado. Observa-se assim o rompimento definitivo com a Doutrina da Situação Irregular, já mencionada em tópico anterior, levando em consideração que as situações de risco pessoal ou social deixam de recair sobre as crianças e adolescente, atribuindo ao Estado e a família o cumprimento na prestação de obrigações que reconheçam e assegurem seus direitos.

As medidas protetivas serão aplicadas a menores, em situação de carência e em conflito com a Lei, de forma isolada ou cumulativamente, bem como substituídas a qualquer tempo, por outra medida mais adequada, conforme especifica o artigo 99 do ECA. (BRASIL, 2016). São aplicáveis à criança, até 12 anos incompletos, que pratique ato infracional, uma vez que não pode ser submetida às medidas socioeducativas; ao adolescente em conflito com a lei, em razão de sua conduta e a criança e adolescente em situação de risco pessoal ou social. Pode-se afirmar que a criança não está sujeita à imposição de qualquer medida socioeducativa, em face de sua condição particular de ser em formação, sem aptidão suficiente para compreender o caráter ilícito do ato infracional praticado.

As medidas de proteção, de acordo com o artigo 101 do ECA são:

I- Encaminhamento aos pais ou responsáveis, mediante termo de responsabilidade;

II- Orientação, apoio e acompanhamento temporários;

III- Matrícula e frequência obrigatória em estabelecimento oficial de ensino fundamental;

IV- Inclusão em programa comunitário ou oficial de auxílio à família, à criança e ao adolescente;

V- Requisição de tratamento médico, psicológico ou psiquiátrico, em regime hospitalar ou ambulatorial;

VI- Inclusão em programa oficial ou comunitário de auxilio, orientação e tratamento a alcoólatras e toxicômanos;

VII- Acolhimento institucional;

VIII- Inclusão em programa de acolhimento familiar;

IX- Colocação em família substituta. (BRASIL, 2016, p. 28).

O Conselho Tutelar pode aplicar as medidas de proteção às crianças e adolescentes carentes e em alguns casos até aos adolescentes em conflito com a lei (as 
medidas dos incisos I a VII do artigo 101 do ECA). Com isso há uma desjudicialização no processo, ou seja, deslocamento de atribuições do poder judiciário para extrajudiciais. A aplicação das medidas protetivas não é necessariamente judicial. O juiz da Infância e da Juventude tem a competência para administrar privativamente as medidas de proteção. (BRASIL, 2016).

Para Naves e Gazoni (2010) as medidas específicas de proteção possuem respaldo nas Regras de Beijing, objetivando a concretização dos direitos fundamentais. Acrescenta que

[...] a normativa introduz uma nova visão acerca da incapacidade da criança de refletir em profundidade sobre o ato cometido em violação à lei, estabelecendo medidas que, em vez de se pautar por uma lógica repressiva e punitiva, tem como objetivo central promover processos educativos e a inserção social e a plena realização da cidadania (NAVES; GAZONI, 2010, p. 195).

Destarte, fica explícito aqui, como a Constituição Federal de 1988 e a legislação especial inovaram e progrediram no que tange as questões da infância e juventude no Brasil. Ao serem arrolados no ECA, esses artigos demonstram seu embasamento na doutrina da proteção integral, que reconhece a criança e o adolescente como sujeitos com necessidades peculiares, não esquecendo da condição de pessoas que se encontram em fase de desenvolvimento psíquico e físico, condição que os coloca em posição de merecedores de especial atenção por parte do Estado, da sociedade e dos pais ou responsáveis.

Partindo para o entendimento do que vem a ser as medidas socioeducativas arroladas no ECA, serão apresentados antes alguns argumentos relevantes sobre os direitos individuais do adolescente em conflito com a lei e também ratificados os conceitos sobre a generalidade e apuração do ato infracional.

No capítulo II, do Título III, o Estatuto da Criança e do Adolescente refere-se aos direitos individuais do adolescente ator de ato infracional. Aqui não se refere mais à criança, pois ela estará sujeita às medidas específicas de proteção, previstas no artigo 101 da lei, apresentada anteriormente. (BRASIL, 2016).

A lei assegura que nenhum adolescente será privado de sua liberdade senão em flagrante de ato infracional ou por ordem escrita e fundamentada da autoridade 
judiciária competente. $\mathrm{O}$ adolescente, no ato de sua apreensão ${ }^{17}$, deverá ser informado de seus direitos e a autoridade deverá sempre identificar-se. A internação do adolescente neste contexto pode ocorrer antes de sua sentença, pelo prazo máximo de quarenta e cinco dias. A decisão precisa ser fundamentada e embasada em indícios suficientes de autoria e materialidade, demonstrando assim a necessidade desta ação. (BRASIL, 2016).

Nenhum adolescente poderá ser privado de sua liberdade sem o devido processo legal. Essa premissa é o que a lei chama de garantias processuais. Dessa forma garantese ao adolescente em conflito com a lei: o pleno e formal conhecimento da atribuição de ato infracional, mediante citação ou meio equivalente; igualdade na relação processual, podendo confrontar-se com vítimas e testemunhas e produzir todas as provas necessárias à sua defesa; defesa técnica por advogado; assistência judiciária gratuita e integral aos necessitados; direito de ser ouvido pessoalmente por autoridade competente e direito de solicitar a presença de seus pais ou responsáveis em qualquer fase do procedimento. (BRASIL, 2016).

Essas garantias processuais, na visão de Neves e Gazoni (2010) podem ser compreendidas como um conjunto de direitos instrumentais e processuais que asseguram princípios fundamentais do Estado Democrático de Direito, ou seja, legalidade e legitimidade (aplicação da lei de forma legítima e não arbitrária).

Já identificados neste trabalho os destinatários das medidas protetivas socioeducativas, aplicadas em decorrência de conflitos com a lei, resta apenas ratificar o que é ato infracional - conduta descrita como crime ou contravenção penal. (Artigo 103 do ECA). Para Bandeira (2006) o ato infracional não pode ser considerado como eufemismo em relação ao crime, pois apesar de objetivamente as condutas serem semelhantes, subjetivamente há uma "diferença abismal" visto que o adolescente não possui discernimento ético para compreender o caráter criminoso do fato ou determinarse de acordo com esse entendimento.

Assim, ao atribuir a um adolescente uma conduta humana que esteja tipificada no Código Penal Brasileiro, na Lei de Contravenções Penais ou qualquer outra, como crime, afirma-se que a ele está sendo imputada a prática de ato infracional e que suscita pela aplicação de medidas pedagógicas. Para Barroso Filho (2006)

\footnotetext{
${ }^{17}$ Regra correlata à garantia constitucional inserida no artigo 5, inciso LXI da Constituição Federal de 1988, pela qual "ninguém será preso senão em flagrante delito ou por ordem escrita e fundamentada da autoridade judiciária competente, salvo no casos de transgressão militar ou crime propriamente militar, definidos em lei”. (BRASIL, 1988, P.1).
} 
[...] importante é que tenhamos consciência de que tratar e recuperar o adolescente infrator implica, necessariamente, em tratar e recuperar a família deste jovem, para que possamos resgatá-lo como elemento útil à sociedade. De todos esses considerados, forçosa é a constatação de que o Estado, em verdade, é co-autor de boa parte das infrações cometidas, pois sua inação em projetos sociais conduz muitos ao desespero, infectando-os em delito. Vale ressaltar: a economia que se faz em educação, saúde, habitação implica em gastos redobrados com segurança pública. Assim, a melhor resposta que se pode dar ao ato infracional é tratar o agente da maneira mais conveniente, no sentido de que a sociedade possa ganhar um cidadão e não um marginal. (BARROSO FILHO, 2006, p. 3).

Destarte, o Estado estará legitimado a privar o adolescente de sua liberdade, restringindo ou afetando o exercício dos seus direitos subjetivos e constitucionais. Verificada a prática de ato infracional, a autoridade competente poderá aplicar ao adolescente as seguintes medidas, conforme descritas no artigo 112:

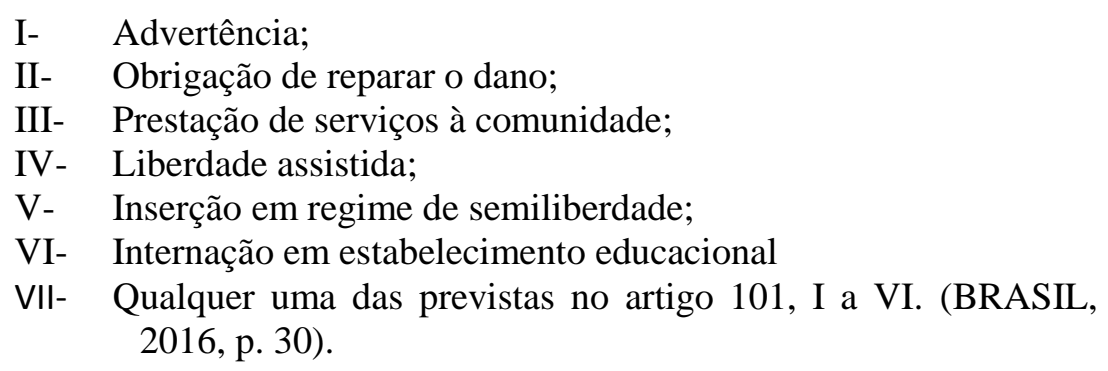

É possível observar que há dois grandes grupos de medidas socioeducativas: medidas não privativas de liberdade (advertência, obrigação de reparar o dano, prestação de serviços à comunidade e liberdade assistida) e medidas privativas de liberdade (inserção em regime de semiliberdade e internação em estabelecimento educacional). A institucionalização de adolescentes, ou seja, as medidas socioeducativas privativas de liberdade devem ser utilizadas somente em casos excepcionais.

O ECA assegura que a medida aplicada ao adolescente levará em conta a sua capacidade de cumpri-la, as circunstâncias e a gravidade da infração. Em nenhuma hipótese será admitido algum tipo de trabalho forçado ao adolescente. E o adolescente portador de doenças ou deficiência mental receberá tratamento individual e especializado, em local adequado às suas condições. (BRASIL, 2016).

Com isso a resposta do Estado precisa estar em consonância com esses princípios adotados pelo ECA, voltados para seu aspecto fundamentalmente pedagógico, face à condição particular e peculiar do adolescente como pessoa em desenvolvimento. Inserir nesse adolescente, em formação, mecanismo de inclusão 
social, aumentando sua autoestima, fortalecendo seus projetos de vida, ampliando horizontes e contribuindo com condições para acreditar em um futuro melhor e digno. $\mathrm{O}$ caráter das medidas socioeducativas deve ser essencialmente educacional e não punitivo (NAVES; GAZONI, 2010).

No entendimento de Bandeira (2006), o conteúdo das medidas socioeducativas precisa ser pautado em um atendimento que atinja, além do adolescente, toda a sua dimensão humana. Nessa dimensão deve haver uma incursão na vida familiar, educacional e social, o que este autor denomina de transindividual, que tem como objetivo aumentar a sua autoestima, despertar valores de cidadania, solidariedade, alteridade, afeto, honestidade, sociabilidade, respeito, entre outros.

Naves e Gazoni (2010) ressaltam que

[...] sancionar não é objetivo da medida socioeducativa, mas um efeito colateral da mesma, de forma que, caso se atinja a meta do bom encaminhamento do adolescente e da prevenção da reincidência infracional de outras maneiras, a medida socioeducativa perde seu objeto e deve ser extinta (NAVES; GAZONI, 2010, p. 216).

É evidente que o sucesso no combate à criminalidade, no crescente percentual de inserção de adolescentes em conflito com a lei e no trabalho de recuperação destes, depende da implantação de políticas sociais básicas que dialogue com diversos programas de proteção especial para estes sujeitos e primordialmente da presença do Estado cumprindo seu papel institucional na área da promoção social.

A seguir serão apresentadas as principais características de cada uma das medidas socioeducativas arroladas no artigo 112 do ECA, com exceção da medida socioeducativa de internação que será apresentada em tópico especifico, em decorrência de ser a utilizada no objeto deste trabalho.

\section{a) Advertência}

A medida socioeducativa de advertência, de acordo com o ECA, no artigo 115, "consistirá em uma admoestação verbal, que será reduzida a termo e assinada" (BRASIL, 2016, p. 31). Ela é destinada ao adolescente que praticou um ato em menor potencial, pouca lesividade ou natureza leve, que mereça apenas uma censura, repreensão por parte da autoridade competente e sempre com intuito educativo. 
Nos termos estabelecidos pelo Parágrafo Único do artigo 114 do ECA, a advertência poderá ser aplicada quando houver indícios suficientes de autoria e prova da materialidade do ato infracional (BRASIL, 2016).

Essa medida não pode ser considerada apenas como um ato de rotina, banalizada ou minimizado o seu caráter sancionatório e socioeducativo (BANDEIRA, 2006; NAVES; GAZONI, 2010). A autoridade competente deve sim, compreender o contexto e as motivações que levaram o adolescente as ações conflitantes com a lei, para então adverti-lo de forma coerente e adequada, para que ele perceba a gravidade dos seus atos.

A tarefa de fazer com que o adolescente perceba a gravidade dos seus atos e as consequência de suas ações para a sociedade, para a família e para a sua própria vida não é fácil. Freire (1983) defende a ideia de que isso pode ser feito se a medida for tomada com cautela e conhecimento, pautada na compreensão, como modo de acolher e educar. Naves e Gazoni (2010) fazendo referência a ilustre obra de Paulo Freire Educação e Mudança (1983, p. 27-41), "afirma que o indivíduo humano em suas interações sociais se caracteriza como um ser de relações e não de mero contato". A advertência tem caráter educativo e a educação deve estar comprometida com a ideia de que o adolescente não é objeto de intervenção modeladora, mas o seu sujeito, capaz de construir uma autocrítica.

\section{b) Obrigação de reparar o dano}

De acordo com o artigo 116 do ECA, em situações em que o ato infracional apresente reflexos patrimoniais, "a autoridade poderá determinar, se for o caso, que o adolescente restitua a coisa, promova o ressarcimento do dano, ou, por outra forma, compense o prejuízo da vítima” (BRASIL, 2016, p. 31). Ainda acrescenta que, na hipótese de impossibilidade, a medida poderá ser substituída por outra adequada. Sendo assim, a reparação do dano tem caráter facultativo e depende sempre das circunstâncias de cada caso. (BRASIL, 2016).

A reparação do dano reafirma os valores ético-sociais e a compreensão por parte do adolescente, da possibilidade de corrigir o seu erro e de demonstrar uma efetiva mudança de atitude. Ressalta-se, no mesmo entendimento de Bandeira (2006), que essa medida não será destinada a maioria dos adolescentes em conflito com lei, oriundos principalmente de lares pobres, vulneráveis, desestruturados e sem qualquer condição de 
arcar com algum prejuízo, pois compõe na maioria dos casos o grupo dos que vivem à margem da sociedade.

\section{c) Prestação de serviços à comunidade}

A prestação de serviços à comunidade, pode ser compreendida, de acordo com o artigo 117 do ECA, como a "realização de tarefas gratuitas de interesse geral, por período não excedente a seis meses junto a entidades assistenciais, hospitais, escolas e outros estabelecimentos congêneres, bem como em programas comunitários ou governamentais". (BRASIL, 2016, p. 31).

O Parágrafo Único, do artigo 117 do ECA ainda estabelece que as tarefas serão "atribuídas conforme as aptidões do adolescente, devendo ser cumpridas durante jornada máxima de oito horas semanais, aos sábados, domingos e feriados ou em dias úteis, de modo a não prejudicar a frequência à escola ou à jornada normal de trabalho". (BRASIL, 2016, p. 31).

A proposta de aplicação dessa medida vincula-se ao contexto de comunidade, pois desperta no adolescente em conflito com a lei, uma consciência social e comunitária. Além disso, Bandeira (2006) destaca que pode medir o senso de responsabilidade do adolescente e sua aptidão para cumprir a medida em meio aberto, pois ele continuará estudando ou trabalhando, vivendo no convívio familiar e dos amigos.

Alguns juristas entendem esta medida como 'pena' alternativa com a intervenção mínima do Estado na esfera individual do adolescente. Consequentemente evita-se a institucionalização (encarceramento) e proporciona condições para que o adolescente reflita sobre seus atos e tome consciência dos valores da cidadania.

Bergalli (2013) reforça o caráter pedagógico da medida socioeducativa de prestação de serviços à comunidade:

[...] a medida possibilita o alargamento da própria visão do bem público e do valor da relação comunitária, cujo contexto deve estar inserido numa verdadeira práxis, onde os valores de dignidade, cidadania, trabalho, escola, relação comunitária e justiça social não para alguns, mas para todos, sejam cultivados durante sua aplicação (BERGALLI, 2013, p. 591). 
A submissão do adolescente a essa medida tem total caráter educativo. No momento em que este passa a conviver com desvalidos, enfermos, ou seja, locais onde as atividades serão prestadas, como hospitais, escolas e estabelecimentos congêneres, o adolescente passa a adquirir (ou pretende que se adquira) uma nova visão acerca do contexto em que vive e de seu próprio papel social e tenha empatia frente a realidade do outro.

\section{d) Liberdade Assistida}

A medida socioeducativa de liberdade assistida " ${ }^{18}$ será adotada sempre que se afigurar a medida mais adequada para o fim de acompanhar, auxiliar e orientar o adolescente" em conflito com a lei (BRASIL, 2016, p. 31). A autoridade designará pessoa com capacitação para estar próximo ao caso, a qual poderá ser recomendada por entidade ou programa de atendimento. O parágrafo segundo do artigo 118 do ECA ainda acrescenta que "a liberdade assistida será fixada pelo prazo mínimo de seis meses, podendo a qualquer tempo ser prorrogada, revogada ou substituída por outra medida, ouvido o orientador, Ministério Público e o defensor" (BRASIL, 2016, p. 31).

Esta medida possui um elevado teor pedagógico, pois sem que o adolescente seja privado de sua liberdade, ele será submetido à construção de um verdadeiro projeto de vida. $\mathrm{O}(\mathrm{s})$ responsável(s) por acompanhar o adolescente e executar a medida, após conhecer a sua história e as circunstâncias que o levaram a essa situação, permite, juntamente com o adolescente, que este colabore na formatação final do seu projeto. A proximidade permite que o adolescente exponha suas fragilidades, necessidades, angustias, objetivos de vida, relate seus medos, conflitos, ajustando assim com o projeto da medida a ser executada de acordo com as condições e realidade daquele adolescente.

Isto posto, Machado (2003) ratifica que

[...] a interação do adolescente com o meio social na sua condição de normalidade do relacionamento humano (o que não se dá no cárcere) também potencializa a possibilidade de o adolescente modificar seu comportamento anterior, para ajustá-lo às regras de convívio social. (MACHADO, 2003, p. 123)

\footnotetext{
${ }^{18}$ A medida socioeducativa de liberdade assistida foi incorporada pela legislação específica seguindo critérios estipulados pelas Regras de Beijing, que no artigo 18.1 do documento traz o seguinte texto: "uma variedade de medidas devem estar à disposição da autoridade competente, permitindo a flexibilidade e evitando ao máximo a institucionalização. Tais medidas, que podem algumas vezes ser aplicadas simultaneamente, incluem: a) determinação de assistência, orientação e supervisão; b) liberdade assistida”.(BRASIL,2016 p.31)
} 
Compete ao orientador, conforme o artigo 119 do ECA, com ajuda e a supervisão da autoridade competente, promover socialmente o adolescente e sua família, fornecendo-lhes orientação e inserindo-os, se necessário, em programa oficial, ou comunitário de auxílio e assistência social; supervisionar a frequência e o aproveitamento escolar do adolescente, promovendo, inclusive a sua matrícula; diligenciar no sentido da profisssionalização do adolescente e de sua inserção no mercado de trabalho e apresentar relatório do caso. (BRASIL, 2016).

É imprescindível que a estrutura física e humana daqueles que serão responsáveis pela aplicação da medida, seja capaz de promover socialmente o adolescente e sua família, inserindo-os em programas sociais, acompanhando o rendimento e a frequência escolar e demais necessidades pertinentes que colaborem no projeto de socialização. (BANDEIRA, 2006).

Na obra de Teixeira (2003) intitulada As histórias de Ana e Ivan: boas experiências em liberdade assistida a autora esboça algumas considerações que devem ser observadas quanto a aplicação dessa medida: o adolescente é um sujeito de direitos; o ato infracional é um aspecto da vida do adolescente que precisa ser compreendido em sua multideterminação; o enfoque do trabalho é transdisciplinar; deve-se ter como base a "lógica do desafio" e não a "lógica do fracasso"; o passado, presente e futuro do adolescente compõem uma biografia única; a trajetória pessoal de casa adolescente está inscrita em um contexto social em que direitos e deveres de cidadania devem ser afirmados, e no qual ele possa realizar suas contribuições e o conhecimento da realidade objetiva da vida do adolescente constitui elemento fundamental para a compreensão de sua personalidade, suas ações, características, etc.

\section{e) Inserção em regime de semiliberdade}

O regime de semiliberdade ${ }^{19}$, de acordo com a legislação específica em seu artigo 120 (ECA), "pode ser determinado desde o início, ou como forma de transcrição para o meio aberto, possibilitada a realização de atividades externas, independentemente

\footnotetext{
${ }^{19}$ Esta medida também foi prevista nas Regras Mínimas das Nações Unidas para a Administração da Justiça, da Infância e da Juventude (REGRAS DE BEIJING) que em seu artigo 29.1 traz o seguinte texto: "Procurar-se-á estabelecer sistemas semi-institucionais, como casas de semiliberdade, lares educativos. Centros de capacitação diurnos e outros sistemas apropriados que possam facilitar a adequada reintegração dos menores à sociedade". (SILVA, 2016, p.37).
} 
de autorização judicial" (BRASIL, 2016, p. 31). Nessa medida é obrigatória a escolarização e a profissionalização, devendo, sempre que possível, ser utilizados os recursos existentes na comunidade. $\mathrm{E}$ ainda, a medida não comporta prazo determinado aplicando-se, no que couber, as disposições relativas à internação.

Tanto nessa medida como na de internação, por serem decorrentes de atos infracionais considerados de maior gravidade para o adolescente e para a sociedade, implica na institucionalização da medida socioeducativa. O que difere uma da outra é que na semiliberdade o adolescente será privado da liberdade de ir e vir nos períodos de maior risco de práticas infracionais e/ou reincidência, que em geral ocorre no período noturno e nos finais de semana.

Assim, como nas demais medidas de caráter pedagógico, necessita de ações e de uma gestão voltada para a construção de projetos de vida que contemplem a construção da cidadania. O adolescente deve estar inserido em uma realidade de atividades externas, principalmente educacionais e de profissionalização, fortalecendo assim seus laços sociais com a família e comunidade (NAVES; GAZONI, 2010).

\subsection{A medida socioeducativa de internação}

O intuito de reservar um tópico específico para abordar a medida socioeducativa de internação justifica-se por ser nela que se configurou a realização desta pesquisa, ocorrida no Centro Socioeducativo de Unaí - CSEUN, cidade localizada no noroeste de Minas Gerais. A internação constitui na medida mais radical dentre todas as demais já descritas, pois priva o adolescente de sua liberdade. Somente pode ser destinada a adolescentes que cometam atos infracionais graves. (BRASIL, 2016).

Embora seja evidente e já apresentado neste trabalho o aspecto pedagógico do ECA, que busca romper com a visão punitiva repressiva, a medida socioeducativa de internação apresenta características coercitivas e educativas (VOLPI, 2015). Deve ser aplicada, conforme descrito pelo legislador no artigo 122 do ECA, quando "tratar-se de ato infracional cometido mediante grave ameaça ou violência a pessoa, por reiteração no cometimento de outras infrações graves e por descumprimento reiterado e injustificável da medida anteriormente imposta” (BRASIL, 2016, p. 31-32). O parágrafo segundo, do artigo 122 do ECA é taxativo em dizer que em hipótese nenhuma será aplicada a medida de internação, havendo outra medida socioeducativa adequada. 
A execução da medida socioeducativa de internação deve observar sempre os princípios dispensados aos adolescentes em geral, garantindo que o período de cumprimento da restrição de liberdade não viole os direitos fundamentais e sociais previstos pela legislação. E por não possuir em tese caráter punitivo, responsabiliza o adolescente em conflito com a lei, tendo como objetivo principal a sua (re)socialização e a reparação do ato quando possível. É neste momento que o Estado precisa garantir oportunidades verdadeiras e acessíveis de educação, profissionalização e apoio psicossocial. (BRASIL, 2016).

De acordo com Baratta (1999) em seu estudo sobre Criminologia Crítica e Crítica do Direito Penal, a prisão não reduz o crime, mas produz estigmatização e reincidência criminal. Ainda para este autor, a execução de medidas que privam adolescentes de liberdade tende a dissocializar este sujeito através da institucionalização.

A concepção de que o ser humano é despersonalizado dentro de instituições fechadas, revelando o processo de desprogramação da pessoa, foi exposta por Goffmann (1974) citado por Campos (2005). Na institucionalização de adolescentes, não sendo diferente, geralmente estes sujeitos demonstram "um estado de ansiedade, insegurança e medo" (CAMPOS, 2005, p. 114). O grande desafio que decorre dessa análise é assegurar que o Estado, a família e a sociedade, olhem para a situação do adolescente em conflito com a lei de modo sistemático para assegurar a implantação de políticas que rompam este estigma. Este olhar não deve ser "através da prisão" e sim "apesar dela".

Destarte, Julião (2013) acrescenta que

[...] somente através da institucionalização nacional de uma política de educação para os sistemas penitenciário e socioeducativo, principalmente privilegiando as ações educacionais em uma proposta política pedagógica de execução penal e de medidas socioeducativas como programa de reinserção social, se conseguirá efetivamente mudar a atual cultura da restrição e privação de liberdade no país (JULIÃO, 2013, p. 16-17).

No desenvolvimento do processo socioeducativo em privação de liberdade é assegurado aos adolescentes garantias constitucionais e estatutárias. Volpi (2015, p. 35) discorre que "a restrição da liberdade deve significar apenas limitação do exercício pleno do direito de ir e vir e não de outros direitos constitucionais, condição para a inclusão na perspectiva cidadã". 
Dentre as garantias, destaca-se que na internação o adolescente está sujeito aos princípios da brevidade, excepcionalidade e respeito à condição peculiar de pessoa em desenvolvimento. (BRASIL, 2016). No que tange a brevidade, a legislação específica quer assegurar que o cumprimento da medida seja utilizado com uma meta especifica, de forma rápida e eficaz. É excepcional ${ }^{20}$, pois sua aplicação só ocorre quando cessar a possibilidade de aplicar outra medida, considerando a gravidade da situação. $\mathrm{O}$ respeito à condição peculiar de pessoas em desenvolvimento, assegura que na aplicação da medida considere a situação real do adolescente em conflito com a lei.

$\mathrm{O}$ artigo 121 do ECA ainda assegura os seguintes direitos, na medida de internação: será permitida ao adolescente
$\S 1^{\circ}$ a realização de atividades externas, a critério da equipe da entidade, salvo expressa determinação judicial em contrário;
$\S 2^{\circ}$ a medida não comporta prazo determinado, devendo sua manutenção sem reavaliada a cada seis meses;
$\S 3^{\circ}$ em nenhuma hipótese o período máximo da internação excederá a três anos;
$\S 4^{\circ}$ atingindo o limite estabelecido no parágrafo anterior, o adolescente deverá ser liberado, colocado em regime de semiliberdade ou de liberdade assistida;
$\S 5^{\circ}$ a liberação será compulsória aos vinte e um anos de idade;
$\S 6^{\circ}$ em qualquer hipótese a desinternação será procedida de autorização judicial, ouvido o Ministério Público [...]”. (BRASIL, 2016, 31).

A internação deverá ser cumprida em estabelecimento exclusivo para adolescentes, em local distinto daquele destinado a abrigo, devendo ser obedecida rigorosa separação por critérios de idade, compleição física e gravidade da infração. (BRASIL, 2016). E mais, é obrigada a realização de atividades pedagógicas no período da medida, inclusive provisória, sendo a escolarização e a profissionalização, direitos de crianças e adolescentes privados de liberdade.

Em pesquisa realizada pelo Conselho Nacional de Justiça - CNJ, intitulada Panorama Nacional: a execução das medidas socioeducativas de internação (2012), conforme levantamento realizado pelo Programa Justiça ao Jovem, vinculado ao Departamento de Monitoramento e Fiscalização do Sistema Carcerário do Conselho Nacional de Justiça, o Brasil possuía, entre julho de 2010 e outubro de 2011, 17.502 internos, distribuídos pelos 320 estabelecimentos de execução de medida socioeducativa

\footnotetext{
${ }^{20}$ A excepcionalidade tem respaldo no artigo 19 das Regras de Beijing, que assegura ao adolescente em conflito com a lei: "caráter excepcional da institucionalização, sendo a internação de um jovem em uma instituição sempre uma medida de último recurso e pelo mais breve período". (SILVA, 2016).
} 
existentes no país. A Figura 04 sintetiza o percentual dos estabelecimentos, no ano referência, quanto aos tipos de atividades pedagógicas, por região:

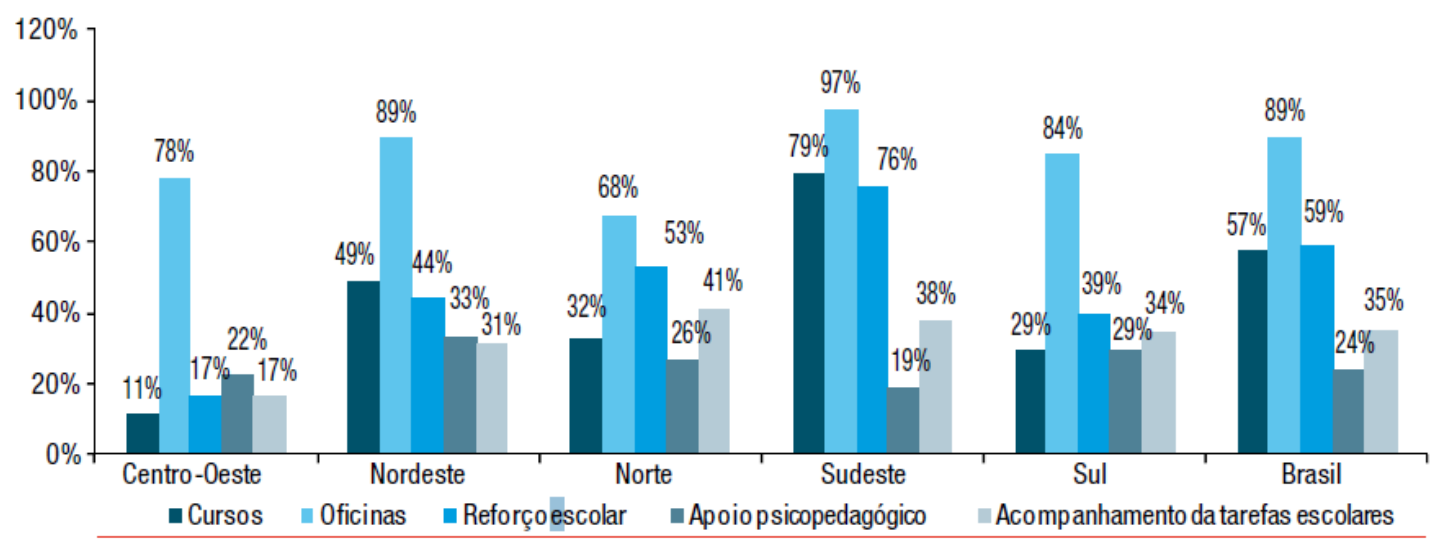

FIGURA 04 - Medidas socioeducativas de internação: percentual dos estabelecimentos quanto aos tipos de atividades desenvolvidas por região.

Fonte: Conselho Nacional de Justiça: Panorama Nacional. A execução das medidas socioeducativas de internação (2012) (CNJ, 2012).

Cada unidade de atendimento socioeducativo de internação será um local com denominação própria, estilo e proposta identificada pela equipe que atua no local (professores, orientadores, profissionais das ciências humanas, trabalhadores sociais, entre outros) e dos próprios adolescentes (VOLPI, 15). Uma das finalidades maior de todo o processo educacional precisa ser a formação para a cidadania.

De acordo com as Regras Mínimas das Nações Unidas para os Jovens Privados de Liberdade $^{21}$, na qual o Brasil é signatário, as unidades de internação devem ser adequadas, cumprindo os seguintes requisitos:

- Atendimento das condições de higiene e dignidade humana;

- Desenho compatível com a sua finalidade, ou seja, a reabilitação do adolescente internado ou em tratamento, levando-se em conta a necessidade de intimidade, de estímulos sensoriais, de participação em atividades esportivas, exercícios físicos e atividades de entretenimento;

- Existência de dormitórios individuais ou para pequenos grupos, tendo-se presente os costumes locais;

- Instalações sanitárias adequadas;

\footnotetext{
${ }^{21}$ Fonte: http://www.dhnet.org.br/direitos/sip/onu/c_a/lex46.ht
} 
- Direito de dispor de objetos pessoais e de contar com lugares seguros para guardá-los;

- Direito de usar suas próprias roupas, na medida do possível, de ter roupas apropriadas para o clima local, suficientes para mantê-lo em boa saúde;

- Alimentação adequadamente preparada e servida em horas habituais, em qualidade e quantidade que satisfaçam as necessidades nutricionais; direito à águas limpa potável a qualquer momento.

A legislação específica, no artigo 124, apresenta os direitos do adolescente privado de liberdade, importantes de serem apresentados neste trabalho, sendo eles:

I - entrevistar-se pessoalmente com o representante do Ministério Público;

II - peticionar diretamente a qualquer autoridade;

III - avistar-se reservadamente com seu defensor;

IV - ser informado de sua situação processual, sempre que solicitada;

$\mathrm{V}$ - ser tratado com respeito e dignidade;

VI - permanecer internado na mesma localidade ou naquela mais próxima ao domicílio de seus pais ou responsável;

VII - receber visitas, ao menos, semanalmente;

VIII - corresponder-se com seus familiares e amigos;

IX - ter acesso aos objetos necessários à higiene e asseio pessoal;

$\mathrm{X}$ - habitar alojamento em condições adequadas de higiene $\mathrm{e}$ salubridade;

XI - receber escolarização e profissionalização;

XII - realizar atividades culturais, esportivas e de lazer:

XIII - ter acesso aos meios de comunicação social;

XIV - receber assistência religiosa, segundo a sua crença, e desde que assim o deseje;

$\mathrm{XV}$ - manter a posse de seus objetos pessoais e dispor de local seguro para guardá-los, recebendo comprovante daqueles porventura depositados em poder da entidade;

XVI - receber, quando de sua desinternação, os documentos pessoais indispensáveis à vida em sociedade. (BRASIL, 2016, p. 32).

Diante do exposto, ratifica-se a ideia de que a medida de internação seja aplicada quando esgotadas as possibilidades de outras mais adequadas. Mas não se pode negar os esforços que atualmente têm sido implantados em todo o sistema de atendimento socioeducativo e em especial nesta medida, com intuito de contribuir na formação do adolescente, de modo que este venha a ser um cidadão autônomo e solidário, capaz de estabelecer um relacionamento melhor consigo mesmo e com os outros $\mathrm{e}$ principalmente assegurar que não reincida na prática de ato infracional. 


\subsection{O Sistema Nacional de Atendimento Socioeducativo - Sinase e a Lei $12.594 / 2012$}

Para assistir aos adolescentes, atores de ato infracional e na tentativa de responder o que pode ser feito no enfrentamento de situações de violência que os envolvem, além das vítimas de violação de direitos no cumprimento de medidas socioeducativas, foi estabelecido no ano de 2006, o Sistema Nacional de Atendimento Socioeducativo - Sinase, através da Resolução nº 119, do Conselho Nacional dos Direitos da Criança e do Adolescente - Conanda ${ }^{22}$.

No mesmo ano de 2006 outras propostas foram encaminhadas ao Congresso Nacional, no intuito de se fazer detalhamentos e complementações em relação ao Estatuto da Criança e do Adolescente - ECA, o que daria origem a uma nova lei, seis anos depois.

No ano de 2012, através da aprovação no Congresso Nacional foi sancionada pela presidenta Dilma Rousseff a Lei de número 12.594, instituindo assim o Sistema Nacional de Atendimento Socioeducativo em todo o território nacional e regulamentando a execução das medidas socioeducativas destinadas a adolescentes que pratiquem ato infracional. Essa normatização conceitual e jurídica implementou os princípios consagrados na CF/88 e no ECA. (BRASIL, 2016).

A Lei 8.069/90 (Estatuto da Criança e do Adolescente - ECA), a Resolução Conanda 119/2006 e a Lei Federal 12.594/12 são normatizações conceituais ${ }^{23} \mathrm{e}$ jurídicas, fundamentais para à implementação dos princípios consagrados na $\mathrm{CF} / 88$, nacionalmente, referente à execução das medidas socioeducativas aos adolescentes em conflito com a lei. O Sinase, "categoricamente tem por fim ordenar cada uma das atribuições legais que se destinem a efetivação das determinações judiciais relativas à responsabilização diferenciada do adolescente” (RAMIDOFF, 2012, p. 13).

O órgão gestor nacional do Sinase é a Secretaria de Direitos Humanos da Presidência da República - SDH/PR, responsável por convocar as instituições do Sistema de Justiça, os governos em todas as esferas, os profissionais da educação, saúde, assistência social, segurança pública, entre outros, para estabelecer o processo de responsabilização do adolescente com um caráter educativo, assegurando que as

\footnotetext{
${ }^{22}$ Dados disponíveis no Portal do Sistema Nacional de Atendimento Socioeducativo http://www.sdh.gov.br. Acesso em 01 de Agosto de 2017.

${ }^{23}$ Apêndice A: Quadro cronológico com as principais normativas sobre o atendimento socioeducativo.
} 
medidas socioeducativas proporcionem direitos a esses sujeitos, (re)socialização, educação, profissionalização, cidadania e, interrompam assim, a trajetória infracional.

O ECA é sem dúvida o marco jurídico da política de promoção e defesa dos direitos da criança e do adolescente. A Resolução Conanda 119/2006 aponta critérios para que o Sinase, articulado com os governos Nacional, Estadual e Municipal desenvolva programas de atendimento em consonância com a família, comunidade e Estado.

A Resolução Conanda, $\mathrm{n}^{\circ} 119 / 2006^{24}$, em seu artigo $2^{\circ}$, define da seguinte maneira a abrangência do Sinase: "O Sinase constitui-se de uma política pública destinada à inclusão do adolescente em conflito com a lei que se correlaciona e demanda iniciativas dos diferentes campos das políticas públicas e sociais” (Brasil, 2006, p. 01). primeiro:

E na própria Lei $\mathrm{n}^{\mathrm{o}} 12.594 / 12$, o Sinase é assim definido em seu parágrafo

[...] entende-se por SINASE o conjunto ordenado de princípios, regras e critérios que envolvem a execução de medidas socioeducativas, incluindo-se nele, por adesão, os sistemas estaduais, distrital e municipal, bem como todos os planos, políticas e programas específicos de atendimento a adolescente em conflito com a lei. (BRASIL, 2016, p. 89).

Na Proposta Legislativa $n^{\circ} 134 / 2009$ que aconteceu na Lei n.12.594/2012, o Senador Flávio Arns, dá o seu parecer à Comissão de Assuntos Sociais do Senado Federal, assegurou:

[...] Entre esses direitos está o de responder por seus atos, inclusive ilícitos, conforme sua condição peculiar de pessoa em desenvolvimento. O ECA contemplou essa peculiaridade ao prever um sistema específico de responsabilização para os jovens infratores, no qual as suas condutas ilícitas são tratadas como atos infracionais. Esse sistema prevê a adoção de medidas socioeducativas, de caráter eminentemente pedagógico, que façam recair sobre o adolescente tutelado a responsabilidade condizente com sua condição, mas tem foco, sobretudo, na reintegração do adolescente à sociedade, promovendo o pleno exercício de seus direitos e deveres enquanto cidadãos. Essas medidas socioeducativas correspondem a intervenções do Estado, da sociedade e da família para incluir construtivamente crianças e adolescentes que pratiquem atos infracionais e proporcionar melhores alternativas para a sua vida (BRASIL, 2012b, s/p).

\footnotetext{
${ }^{24}$ Disponível em: file:///D:/Downloads/Resolucao\%20no\%20119\%20CONANDA\%2011\%20DE\%20DEZEMBRO\%20DE \%202006.pdf
} 
A Lei 12.594, de 18 de janeiro de 2012, desde então, dispõe da organização, estruturação e funcionamento, bem como regulamenta as atividades, diretrizes e práticas na execução das medidas socioeducativas, determinadas judicialmente a adolescentes em conflito com a lei. (RAMIDOFF, 2012).

Essas medidas têm por objetivo responsabilizar o adolescente quanto às consequências lesivas do ato infracional, sempre que possível incentivando a sua reparação. Busca também a integração social do adolescente e a garantia de seus direitos individuais e sociais, por meio do cumprimento de seu plano individual de atendimento. E por fim, tem como objetivo a desaprovação da conduta infracional, efetivando as disposições da sentença como parâmetro máximo de privação de liberdade ou restrição de direitos, observados os limites previstos em lei (BRASIL, 2016).

Por ser um conjunto ordenado de princípios, regras e critérios, com definidas competências à União, aos estados e aos municípios, o Sinase envolve desde o processo de apuração do ato infracional até o cumprimento da medida socioeducativa. Neste conjunto atuam concomitantemente o sistema educacional, sistema de saúde, sistema de assistência social e o sistema de justiça e segurança pública (BRASIL, 2016).

Tendo em vista que houve uma mudança de mentalidade do Estado no exercício de legislar que foi conferida pela Carta Magna de 1988 e no próprio ECA, a política agora concretizada, proporciona um caráter educativo, com finalidade de que no decorrer do implemento da medida socioeducativa exigida, onde o educando cria o seu senso de compromisso e, por isso assume a "direção" do seu futuro, conte com o apoio familiar, estatal e da sociedade e mostre as mudanças e suas conquistas.

O Ministério dos Direitos Humanos, por meio da Secretaria Nacional dos Direitos da Criança e do Adolescente disponibilizou no início do ano de 2018, o último Levantamento Anual SINASE, com dados referentes a 30 de novembro de 2015. Dados estes sistematizados e enviados à Coordenação-Geral do SINASE pelos órgãos gestores. O relatório revelou um número total de 26.209 adolescentes e jovens no Brasil, sendo que deste total, 18.381 em medida de internação, 2.348 em regime de semiliberdade e 5.480 em internação provisória. O relatório ainda mostrou que há, ainda, outros 659 adolescentes/jovens em atendimento inicial, internação sanção e medida protetiva (medida socioeducativa suspensa para tratamento em clínica de saúde), totalizando 26.868 adolescentes jovens em privação e restrição de liberdade. (BRASIL, 2018). 
A construção legislativa apresenta Princípios e Diretrizes capazes de assegurar, dentre inúmeros quesitos, uma (re)socialização através de parâmetros Educacionais de qualidade, pois o seu teor pedagógico reconhece a escolarização como elemento estruturante de todo o sistema. De acordo com o doutrinador Volpi, as medidas socioeducativas

[...] comportam aspectos de natureza coercitiva, vez que são punitivas aos infratores, e aspectos educativos, no sentido da proteção integral e oportunização e do acesso à formação e informação, sendo que, em cada medida, esses elementos apresentam graduação, de acordo com a gravidade do delito cometido e/ou sua reiteração (VOLPI, 2011, p. 20).

No que tange aos princípios, estes servem como diretrizes para o cumprimento das medidas, tanto as protetivas quanto as socioeducativas, sendo eles: legalidade, excepcionalidade, prioridade restaurativa, proporcionalidade, brevidade, individualização, mínima intervenção, igualdade e convivencialidade (RAMIDOFF, 2015).

Sobre aos objetivos do Sinase é importante destacar previamente que suas ações são realizadas tendo como base um Plano Nacional de Atendimento Socioeducativo. Um dos objetivos é articular em todo território nacional, os governos Estaduais e Municipais, o Sistema de Justiça e as políticas setoriais básicas (Assistência Social, Saúde, Educação, Cultura, etc.) para garantir a efetividade na execução de todas as medidas socioeducativas. Outro objetivo é o desenvolvimento de uma ação socioeducativa com base nos princípios dos direitos humanos, sustentados em uma estrutura ética e pedagógica.

$\mathrm{Na}$ natureza pedagógica da medida socioeducativa, o Sinase tem como plataforma os acordos internacionais sobre direitos humanos, dos quais o Brasil é signatário, com atenção àqueles na área dos direitos da criança e do adolescente. Entre as principais normativas da ONU para a socioeducação estão as Regras mínimas para a administração da Justiça da criança e do adolescente, também conhecidas como as Regras de Beijing, adotadas pela ONU na Resolução 40/33 de 1985. Destacam-se também os Princípios Orientadores das Nações Unidas para a Prevenção da Delinquência Juvenil, também conhecidos como os Princípios Orientadores de Riad, que foram adotados pela ONU na Resolução 45/112 de 1990, ambas já apresentadas neste trabalho. 
Ainda no contexto do Sistema Nacional de Atendimento Socioeducativo, no ano de 2013 foi aprovado através da Resolução Conanda 160, o Plano Nacional de Atendimento Socioeducativo ${ }^{25}$, que tem como objetivo definir expectativas e estratégias de longo prazo, determinando a alocação de recursos públicos para cada exercício. (BRASIL, 2013). As estratégias passam por quatro eixos: Gestão, Qualificação do Atendimento, Participação Cidadã dos Adolescentes e Sistemas de Justiça e Segurança.

Os quatro eixos, além das sessenta e três metas e treze objetivos que organizam o Plano Nacional do Sinase estão distribuídos em três períodos: $1^{\circ}$ período, ocorrido de 2014 a 2015, compreendeu as implantações sugeridas no documento, formulação dos Planos Estaduais e Distrital do Plano Decenal, bem como a primeira avaliação nacional do Sinase; $2^{\circ}$ período, iniciado em 2016 até 2019 e o $3^{\circ}$ período que vai de 2020 a 2023.

O Plano Nacional do Sinase, tendo como referência o ECA, a Resolução Conanda 119/2006 e a Lei Federal 12.594/12, apresenta os seguintes princípios:

1 - os adolescentes são sujeitos de direitos, entre os quais a presunção da inocência; 2 - ao adolescente que cumpre medida socioeducativa deve ser dada proteção integral de seus direitos; e 3 - em consonância com os marcos legais para o setor, o atendimento socioeducativo deve ser territorializado, regionalizado, com participação social e gestão democrática, intersetorialidade e responsabilização, por meio da integração operacional dos órgãos que compõem esse sistema. (BRASIL, 2013, p.09).

O ano de 2013 representou também um importante marco no Sistema Nacional de Atendimento Socioeducativo com a implantação da Escola Nacional de Socioeducação - ENS. O principal objetivo é proporcionar formação continuada para os múltiplos profissionais que atuam direta ou indiretamente no Sinase, além de ter como objetivo a criação de uma unidade metodológica e curricular em todo o país. Garante assim, que os programas de formação consigam articular a teoria e a prática, à construção coletiva do conhecimento, a troca de experiências, a valorização dos saberes profissionais, a reflexão crítica, a sistematização e o registro das práticas institucionais, bem como a construção de fundamentos teóricos e metodológicos comuns. (BRASIL, 2014).

Destarte, a ENS contribui para que não haja multiplicidade de modelos de formação e a atuação dos profissionais siga parâmetros e diretrizes que respeitem integralmente os direitos dos adolescentes que cumprem medidas socioeducativas,

\footnotetext{
${ }^{25}$ Plano Nacional de Atendimento Socioeducativo: Diretrizes e eixos operativos para o SINASE. Resolução CONANDA 160, de 18/11/2013.
} 
efetivando as políticas estabelecidas pelo ECA, Resolução Conanda 119/2006, LF 12.594/12 e pelas normativas internacionais, nas quais o Brasil é signatário. Os profissionais podem assim fundamentar as suas práticas, trocar experiências e aprimorar os instrumentos de trabalho, tendo como foco principal o adolescente e a garantia de seus direitos.

No que tange aos fundamentos da ENS, a metodologia e a escolha dos conteúdos curriculares estão referenciadas na proteção integral dos direitos dos adolescentes, observando os princípios, fundamentos e normativas legais já expostos aqui. Tanto os métodos quanto os conteúdos precisam dialogar com os princípios da Proteção Integral, na promoção, garantia e defesa dos direitos dos adolescentes em conflito com a lei. $\mathrm{O}$ documento Parâmetro de Gestão, Metodológicos e Curriculares ${ }^{26}$ (BRASIL, 2014), da ENS, descreve que os profissionais, no exercício da socioeducação:

[...] reconheça os direitos humanos como fundamento das relações sociais, compreendendo a educação em direitos humanos como estruturante na socioeducação e não apenas como fundamento jurídico. Compreenda as atitudes do (da) adolescente como síntese de um processo histórico e comunitário e que a violência e o cometimento de atos infracionais têm origem na vulnerabilidade proporcionada pela sociedade. Compreenda a relevância dos meios de comunicação na formação da opinião pública em relação aos adolescentes em conflito com a lei, ao SINASE e a imputabilidade penal de crianças e adolescentes. Fundamente-se na diversidade de abordagens pedagógicas e em práticas mediadoras das situações de conflito, dentre as quais podemos citar: cultura da não violência, práticas restaurativas, entre outras. Apreenda concepções filosóficas de humanidade, de mundo e de conhecimento para fundamentar a distinção entre a socioeducação e as práticas correcionais e repressivas. (BRASIL, 2014, p. 5).

O Levantamento Anual Sinase 2014 apresentou em seu relatório o número de profissionais por categoria no Brasil, como assistentes sociais, psicólogos e pedagogos, na área de saúde e jurídica. Os profissionais que compõem a equipe multidisciplinar apresentaram a seguinte distribuição: assistente social 4\% (1.318), psicólogo/a 3\% (1.144) e pedagogo/a 2\% (694). Os advogados e técnicos/as em enfermagem representam, respectivamente, $1 \%$ (196) e 1,3\% (432) dos profissionais. (BRASIL, 2014).

\footnotetext{
${ }^{26}$ Parâmetros de Gestão, Metodológicos e Curriculares da ENS. Portal da Escola Nacional de Socioeducação. Disponível em http://ens.sinase.sdh.gov.br/.
} 


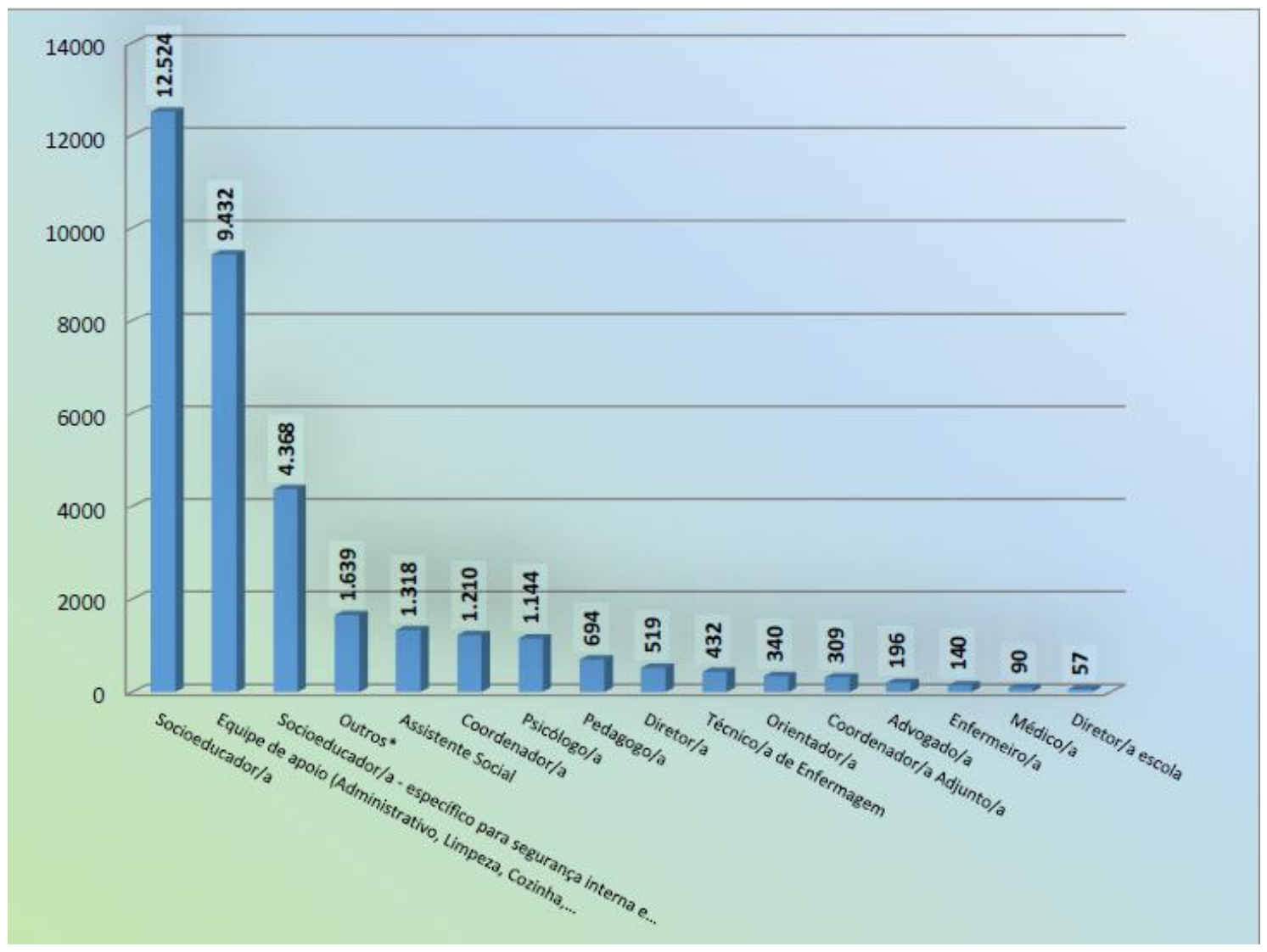

FIGURA 05 - Profissionais do SINASE por categoria - Total Brasil em 2014 Fonte: Levantamento Anual SINASE- 2014.

Fonte: (BRASIL, 2017).

Um dos desafios das políticas voltadas para o atendimento socioeducativo é concretizar toda a proposta legal e articular com todos os envolvidos. O trabalho só será de fato eficiente se houver uma interação e sensibilidade entre todos os envolvidos. Conforme Freire (1998) é possível afirmar que o trabalho desenvolvido em toda a(s) Unidade e, especificamente na escola, seja competente, libertador, solidário, integral, produtivo, lúdico - uma escola que, mesmo sendo séria, não se torne sisuda.

\subsection{O eixo escolarização na medida socioeducativa de internação}

A Constituição Federal de 1988 e o Estatuto da Criança e do Adolescente asseguram que as concepções de atendimento aos adolescentes atores de ato infracional sejam pautadas na educação e cidadania. O principal objetivo ditado por essas normativas é que as unidades de atendimento socioeducativo, destinadas à internação, 
se tornem instituições educacionais, com características organizacionais eminentemente pedagógicas e que não sejam vistas como locais de reclusão ou de punição.

Nas palavras de Elias (2005, p. 79) "o termo educação deve ser entendido como o trabalho sistematizado seletivo e orientador, pelo qual nos ajustamos à vida de acordo com as necessidades ideais e propósitos dominantes". O direito a essa educação consiste no conjunto de direitos fundamentais, ou seja, direitos dos seres humanos conhecidos e positivados na esfera do Direito Constitucional. A educação deve ser articulada aos princípios e fins da $\mathrm{CF} / 88$, sendo prevista no artigo 205:

Art. 205. A educação, direito de todos e dever do Estado e da família, será promovida e incentivada com a colaboração da sociedade, visando ao pleno desenvolvimento da pessoa, seu preparo para o exercício da cidadania e sua qualificação para o trabalho. (BRASIL, 1988, p. 160).

O ECA em seu artigo 53 e seguintes, reforça a ideia de que a criança e o adolescente tem direito à educação, visando ao pleno desenvolvimento de sua pessoa, preparo para o exercício da cidadania e qualificação para o trabalho (BRASIL, 2016).

Para Naves e Gazoni (2010)

[...] esses direitos preparam a criança e o adolescente para a vida adulta. O direito maior assegurado pelo artigo 53 do Estatuto é o direito à educação. A criança que não é educada tem cerceado seu direito de inserção e participação na sociedade. A educação deve garantir pleno desenvolvimento da pessoa humana, preparar para o exercício da cidadania e qualificar para o trabalho (NAVES; GAZONI, 2010, p. 87).

A Lei de Diretrizes e Bases - $\mathrm{LDB}^{27}$, Lei 9.394/96, também serve de embasamento na concepção de educação no sistema socioeducativo. Esta Lei, extraída de sua versão online, define que:

Art. $1^{\circ}$ A educação abrange os processos formativos que se desenvolvem na vida familiar, na convivência humana, no trabalho, nas instituições de ensino e pesquisa, nos movimentos sociais e organizações da sociedade civil e nas manifestações culturais.

Art. $2^{\circ}$ A educação, dever da família e do Estado, inspirada nos princípios de liberdade e nos ideais de solidariedade humana, tem por finalidade o pleno desenvolvimento do educando, seu preparo para o exercício da cidadania e sua qualificação para o trabalho. (BRASIL, $1996, \mathrm{~s} / \mathrm{p})$

A Lei 12.594/12 assegurou que os Conselhos dos Direitos da Criança e do Adolescente, em todos os níveis federados, em conjunto com os órgãos responsáveis

${ }^{27}$ Disponível em: http://www.planalto.gov.br/ccivil_03/leis/L9394compilado.htm 
pelo sistema de educação pública e as entidades de atendimento, assegurem a inserção de adolescentes em cumprimento de medida socioeducativa na rede pública de educação. A inserção de adolescentes em cumprimento de medida socioeducativa na rede pública, conforme e referida lei, deverá ser realizada independentemente do período letivo, inclusive contemplando as diversas faixas etárias e níveis de instrução. (BRASIL, 2016).

A centralidade da escola é garantida na medida socioeducativa de internação. Tendo como exemplo o Centro Socioeducativo de Unaí - CSEUN, lócus desta pesquisa, face a impossibilidade dos adolescentes frequentarem escolas na comunidade de origem ou outra que estava matriculado, a rede pública e regular do estado de Minas Gerais, mantêm uma escola dentro da unidade. Na data da coleta dos dados, havia 102 adolescentes internados e todos estavam regularmente matriculados na escola.

Uma característica comum nas unidades de atendimento socioeducativo é o fato de muitos adolescentes que ingressam na medida não possuírem mais vínculo com o ambiente escolar, pois antes mesmo de cumprir alguma medida socioeducativa já haviam abandonado a escola ou encontravam-se "em conflito" com ela. Outra característica é que nas escolas fora da unidade de internação, as experiências escolares em alguns casos são marcadas pela violência, repetência, expulsões e interrupções no estudo. Isso mostra a complexidade em torno das práticas educacionais nesses ambientes para fazer com que o adolescente se habitue novamente ao processo educativo, sinta-se atraído pelas aulas e internalize os seu reais objetivos.

Por isso a importância de se desenvolver atividades que respeitem a dignidade destes sujeitos e a condição de pessoa em desenvolvimento, que transitem pelos princípios da cidadania e dignidade humana. Atividades essas, que rompam com a educação repressiva, de caráter punitivo e que não apresenta nenhuma relação direta com a realidade do mundo exterior, ou seja, não prepara o adolescente para a (re)socialização/(re)educação. Em algumas situações o adolescente não tem a clareza da importância da educação formal e não formal em sua formação. Para alguns, frequentar as aulas só ocorrem por imposição da medida ou determinação judicial, não vinculando a importância que tem para o seu presente e futuro (projetos de vida).

O ECA estabelece no inciso XI do seu artigo 124 que, além da escolarização, o adolescente privado de liberdade tem direito a profissionalização. As atividades extraclasses desenvolvidas nas unidades precisam proporcionar o desenvolvimento das 
potencialidades e habilidades dos adolescentes e contribuir no processo de (re)socialização e colocação no mercado de trabalho após cumprir a medida. A educação e a profissionalização são ferramentas instrumentais para a inserção nesse mercado, das novas gerações e de todas as classes sociais. (BRASIL, 2016).

No entanto há algumas discussões e apontamentos negativos feitos as atividades profissionalizantes desenvolvidas em algumas unidades de atendimento socioeducativo. Essas atividades, com frequência, não instrumentalizam tecnicamente os adolescentes. Nas palavras de Volpi (2015) estudos e pesquisas tem demonstrado que adolescentes em conflito com a lei, cumprindo medida socioeducativa de internação, adotam uma concepção negativa em relação ao trabalho, em decorrência do tipo de atividade que são sujeitos. Este mesmo autor as descreve como

[...] Obrigatoriedade de realização de atividades sem utilidade prática para o grupo ou a sociedade; utilização das atividades de manutenção do espaço, inclusive a limpeza de latrinas e banheiros como castigo pela desobediência a normas pouco claras e arbitrariamente definidas; não participação dos adolescentes no planejamento e nos lucros das chamas atividades produtivas. (VOLPI, 2015, p.45).

Ainda no que tange a essas atividades profissionalizantes, ao serem avaliadas no mercado de trabalho, correspondem a atividades de remuneração mínima e bem abaixo da média, cuja empregabilidade se concentra na informalidade. Percebe-se que há uma reprodução da miséria e vulnerabilidade que caracteriza a existência das várias gerações de sujeitos atendidos no sistema socioeducativo, visto que, nas palavras de Pinheiro (2013, p.93) "as instituições que atendem crianças e adolescentes das camadas populares, limitam-se a oferecer cursos pobres para pobres".

As confecções de pano de prato e tapete, técnicas de bordado, artesanato, pintura, carpintaria, marcenaria, atividades comumente utilizadas em ambientes de restrição de liberdade como "atividades" profissionalizantes, sem menosprezar aqui os ônus destes ofícios e o significado no contexto institucional, já não constituem na atualidade como alternativa viável de preparação dos adolescentes internos para enfrentar o mundo moderno, dinâmico e tecnológico (PINHEIRO, 2013). Atualmente nota-se uma redução dos postos de trabalhos e uma exigência cada vez maior e acirrada de mão de obra qualificada, o que tem afetado diretamente a juventude e principalmente os egressos de unidades socioeducativas.

A escolarização na medida socioeducativa de internação, pelo viés da educação formal, não formal e da profissionalização, possibilita a ampliação da capacidade dos 
adolescentes se posicionarem frente aos desafios, fortalecendo a realização dos seus objetivos e projetos de vida. A escolarização contribui no processo da formação cidadã, desenvolvendo habilidades e competências. 


\section{CAPÍTULO 03}

\section{PRÁTICAS EDUCACIONAIS NA FORMAÇÃO E (RE)SOCIALIZAÇÃO DE ADOLESCENTES EM RESTRIÇÃO DE LIBERDADE}

“[... ] melhor afirmação para definir o alcance da prática educativa em face dos limites a que se
submete é a seguinte: não podendo tudo a prática educativa pode alguma coisa." (FREIRE, 1993, p. 47).

Toda prática educativa é notavelmente social, pois ela objetiva capacitar cada sujeito para viver em grupo e ser capaz de comunicar-se. Tem a capacidade de criar uma rede que engloba além do conhecimento, cultura, arte, costumes, educadores e educandos, em múltiplos espaços em que o processo educativo pode acontecer.

Diversos autores têm debruçado sobre uma definição clara e objetiva do que é educação, terreno no qual apresenta inúmeras concepções e correntes de abordagem. Basicamente são três campos no qual a educação pode ser vivenciada: educação informal, formal e não-formal. A proposta deste capítulo não é aprofundar nestes eixos, mas é fundamental que se tenha uma clara diferenciação entre cada um para se compreender melhor o que se propõe aqui.

Este trabalho tem como embasamento teórico a obra de Gohn (2010) para trazer os conceitos de educação formal, informal e não formal. Para esta autora a educação formal consiste naquela desenvolvida nas escolas, com conteúdo previamente demarcado. A educação não formal é aquela que se aprende no mundo da vida, nos processos de compartilhamento de experiências, principalmente nos espaços de ações coletivas do cotidiano. E, por fim, a educação informal pode ser entendida como aquela na qual os indivíduos apreendem durante seu processo de socialização, criada nas relações intra e extra familiares.

No que tange ao educador, na educação formal são fundamentalmente os professores seus principais agentes, embora os demais profissionais que atuam nas escolas tenham caráter educativo pelo seu significado. $\mathrm{O}$ educador na educação não formal é a figura do educador social. Na informal, a figura do educador está nos sujeitos que são estabelecidas as relações intra e extra familiar (pais, amigos, vizinhos, colegas, etc.) $(\mathrm{GOHN}, 2010)$. 
Os espaços onde se educa na educação formal são o do território das escolas, geralmente instituições regulamentadas por lei, certificadores e seguidoras de diretrizes nacionais. $\mathrm{O}$ ato de educar ocorre por meio de regras, legislações e padrões de comportamento bem definidos. A finalidade e objetivo da educação formal é basicamente os relativos ao ensino e aprendizagem dos conteúdos sistematizados ao longo da grade curricular (GOHN, 2010).

O espaço físico onde transcorrem os atos da educação não formal são os territórios que acompanham as trajetórias de vida dos grupos e indivíduos, onde ocorrem processos de interação intencional. Os ambientes e as situações interativas são construídos coletivamente, seguindo as diretrizes do grupo - é assim que se educa na não formal. Há na educação não formal uma intencionalidade na ação, no ato de participar, de aprender e de transmitir ou trocar saberes. A finalidade dela é capacitar as pessoas a se tornarem cidadãos do mundo e no mundo. (GOHN, 2010).

$\mathrm{Na}$ educação informal os espaços assumem diversas referências como nacionalidade, localidade, sexo, idade, religião, entre outros. A educação nela ocorre por meio de ambientes espontâneos onde as relações sociais se desenvolvem naturalmente (gostos e preferências herdados). A finalidade da educação informal é socializar os sujeitos, desenvolvendo habilidades, atitudes e comportamentos que expressam os valores e crenças do seu grupo (território). (GOHN, 2010).

Diante do exposto é oportuno salientar que a educação não formal é um dos caminhos para se compreender melhor o termo socioeducação, principalmente por capacitar o sujeito para o mundo, formar cidadãos e abrir diferentes alternativas de se relacionarem com o meio em que vivem. Neves (2008) fazendo essa aproximação, discorre que a educação não formal

[...] localiza-se no seio dos projetos sociais geridos por ações governamentais, não governamentais e pela parceria entre ambos. Suas ações são direcionadas a crianças, jovens e adultos em situação de exclusão social, e seus objetivos visam contribuir para a formação integral do indivíduo, objetivando promover o crescimento pessoal, a consciência da cidadania e, muitas vezes, a possibilidade de sua (re)inserção na sociedade. É nesse âmbito que ela se denomina educação social, calcada em ações que objetivam uma educação para a vida, e muitas vezes, ligada a programas de prevenção à criminalidade (NEVES, 2008, p. 104)

Um bom exemplo seria as práticas educacionais desenvolvidas em unidade prisionais e de atendimento socioeducativo de internação. Especificamente a Unidade 
alvo desta pesquisa, foi possível identificar que os adolescentes não se limitam apenas a aulas de ensino fundamental e médio que ali são ofertadas. As práticas educacionais desenvolvidas nessa unidade, e em muitas outras, pretendem ir além dos limites da sala de aula e promover uma sensibilização ou até mesmo desenvolver novos sentimentos, valores e culturas naqueles que estão inseridos no processo. Ao contrário da educação informal, que segundo GOHN (2010) essas características são de pertencimento e herdadas.

O aprendizado gerado pelas práticas educacionais, entendido sobre o viés da educação não formal, não deve ser espontâneo "porque os processos que o produz têm intencionalidades e propostas" (GOHN, 2010, p. 16). E acredito que possa ser um importante viés a ser utilizado para se trabalhar com crianças e adolescentes vulneráveis a inserção em práticas e atos infracionais.

Ao contrário do que se prega no senso comum e do temor social decorrente do crescimento da violência e criminalidade, que atribui ao processo de institucionalização de crianças e adolescentes a "solução" desses problemas, o investimento na educação não formal pode proporcionar retornos muito mais expressivos. Mesmo porque, a institucionalização, de acordo com os princípios do ECA, é breve, excepcional e prioriza o respeito à condição peculiar de pessoa em desenvolvimento. (BRASIL, 2016).

Antes de se pensar em privar a liberdade de um adolescente em conflito com a lei, é preciso fomentar a liberdade nos seus espaços de vivência, junto a família, amigos e comunidade; locais que acompanham as trajetórias de vida dos grupos e sujeitos. É fundamental que as políticas públicas, voltadas para esses sujeitos, invistam mais em ações que promovam oportunidades de debates e acesso à informação e conhecimento, que contribua para sua formação pessoal e cidadã. Rodas de conversa, projetos de socialização e escola que promovam uma educação de qualidade.

Destarte, neste capítulo serão apresentadas breves considerações sobre a educação social e o eixo socioeducativo, principalmente, nas medidas socioeducativas elencadas no ECA. Será apropriado o uso do trocadilho "celas de aula", por entender a autenticidade que essa expressão transmite quando se traz a lume a discussão sobre a realidade de adolescentes em conflito com a lei e detentos em geral. Pretende-se trazer uma compreensão dos espaços de controle e privação de liberdade e dos sujeitos inseridos, que criam e recriam o espaço e a vida social no contexto onde vivem. A 
expressão "celas de aula" já foi usada por alguns autores que discutem sobre a educação em ambientes prisionais, como Oliveira (2012), e Duarte (2013). E por fim, alguns apontamentos sobre a (re)socialização no contexto educacional dos adolescentes em conflito com a lei.

\subsection{O que é socioeducação?}

O conceito de educação social está intrinsecamente ligado ao contexto social, às formas políticas, à cultura, ao modelo econômico e a todas as outras formas de manifestação expressa pela sociedade, em tempo e espaço definidos. Por isso há uma dificuldade em definir o termo, por aqueles que se debruçam nas suas pesquisas, ficando muito explícito que há diversas acepções e formas distintas de interpretá-las. Essas interpretações levam no primeiro momento ao entendimento do que é pedagogia social disciplina da pedagogia, que pertence à ordem do discurso (PEDRON, 2012).

De acordo com Díaz (2006) a pedagogia social surge na Alemanha, em meados do século XX, relacionada com a sociedade industrial, após uma crise belicista, sendo vista como restauradora dos danos sociais e humanos pela qual a Europa vinha sendo assolada. Surgiu da necessidade de proporcionar metodologias educativas específicas a grupos em necessidades, para a superação de conflitos sociais, prevenção de situações de risco e de vulnerabilidade social (CALIMAN, 2006). Isso gerou a necessidade de se pensar em uma pedagogia que desse respostas as mazelas vividas ali, como migrações, desemprego, delinquência, etc. As necessidades então passaram a ser de ordem coletiva, social e comunitária.

No Brasil a educação social vai surgir por volta das décadas de 1960 e 1970, tendo como base o assistencialismo das políticas públicas, debatido pela sociedade civil que passa a assumir responsabilidades nos projetos sociais. Assim, as igrejas, organizações não governamentais e associações passam a impulsionar e cuidar de classes menos favorecidas, principalmente por meio de alfabetização de jovens e adultos e educação popular. Um dos grandes representantes da pedagogia social no Brasil foi o professor Paulo Freire, que propôs uma educação voltada para a politização daqueles tidos como oprimidos, como prática de libertação (MACHADO, 2014; PEDRON, 2012, NAVES, 2005). 
A década de 1980 foi marco considerável da educação social no Brasil com a promulgação da nova Constituição Federal em 1988, no processo vivido pelo país conhecido como redemocratização. Organismos não governamentais e outros segmentos organizados da sociedade civil passam a buscar soluções de caráter coletivo a fim de atingir o Estado de Bem Estar Social. Pedron (2012) acrescenta que

[...] com isso, surge a necessidade de uma pedagogia social que fosse capaz de abarcar a nova realidade e contexto social expressos no texto da Constituição de 1988, como os quilombolas, a mulher, a população rural, as crianças e os adolescentes, o idoso e todos aqueles que antes não gozavam de plenos direitos e garantias. Essa nova forma de educação é de cunho essencialmente prático e menos teórico, de caráter coletivo e interdisciplinar (PEDRON, 2012, p. 60).

Algumas legislações, tanto de cunho internacional como nacional, serviram de marco legal para a educação social, com destaque para: Declaração Universal dos Direitos Humanos; a Declaração dos Direitos da Criança e a Convenção Internacional dos Direitos da Infância; o Estatuto da Criança e do Adolescente - ECA; a Lei 7.853, de 1989, da pessoa portadora de deficiência; a Lei orgânica da saúde, número 8.080 de 1990; a Lei 8.142, de 1990, do Sistema Único de Saúde (SUS) e a Lei Orgânica da Assistência Social (LOAS), de 1993.

Essas leis têm em comum o cuidado pela garantia dos direitos humanos e direitos sociais, assegurando o acesso à saúde, à educação, ao lazer, respeitando a dignidade da pessoa humana e objetivando seu desenvolvimento físico, moral e social. Além disso, todo esse ordenamento jurídico caminha para uma parceria entre a sociedade, a família e o Estado, visando o pleno cuidado dos seus membros (crianças, adolescentes em diversas situações, sujeitos público alvo da educação especial, idosos, etc.) formando o campo de prioridade para as atividades socioeducativas (PEDRON, 2012).

Para Díaz (2006, p.99) a Educação Social é:

[...] uma progressiva e contínua configuração do indivíduo para alcançar o seu desenvolvimento e conseguir a participação na comunidade, o que deverá ajudá-lo a compreender o mundo e a si mesmo; a educação é uma dimensão inseparável dos indivíduos e das comunidades e, por isso, a educação é ao longo de toda a vida, acompanha o homem do nascimento até a morte; uma educação entendida ao longo da vida deve verificar-se em todo o espaço espacial e temporal e, por isso, a educação escolar será mais um aspecto da mesma, evitando centrar-se exclusivamente na transmissão de conteúdos instrutivos; toda a educação é, ou deve ser social, já que quando falamos de educação esta se faz na família, na escola, na 
comunidade e, inclusive, para a comunidade; a educação social deve estar inserida no contexto da educação ao longo da vida, e também, às vezes, deve concretizar-se em espaços e tempos distintos dos da educação escolar. (DIAZ, 2006, P.99).

Destarte, é importante contextualizar aqui educação escolar com o eixo socioeducativo, e especificamente aquele voltado ao atendimento de adolescente em conflito com a lei, que cumpre medida socioeducativa de internação, objeto central desta pesquisa. Para isso Díaz (2006) analisa uma série de elementos que considera como eixos da educação social, entre eles o eixo da socioeducação e diz que

[...] o âmbito socioeducativo é o espaço disciplinar onde se realiza a práxis da educação social. Na perspectiva desta acção prima a dimensão social do sujeito, já que este não o é senão no contexto da sua presença na comunidade. Por seu lado, a acção socioeducativa é entendida como ajuda social, e esta formula-se desde o apoio e a mediação social. Aqui é onde entra a educação social que, do mesmo modo que outras disciplinas sociais, exerce a mediação para prevenir as situações de escassez e garantir a promoção dos indivíduos. (DÍAZ, 2006, p. 102).

Perante o convívio habitual com adolescentes que cumprem a medida socioeducativa, especialistas e profissionais que atuam na área do Sistema Nacional de Atendimento Socioeducativo (Sinase), pleiteiam adquirir a compreensão necessária com o fito de ajudar esses sujeitos a promoverem uma ressignificação em suas vidas, bem como edificar novos caminhos a serem seguidos.

Sob o ponto em que passou a viger o Estatuto da Criança e do Adolescente ECA e o Sinase, estes demonstraram grandes evoluções e triunfos no âmbito da legislação concernente aos direitos dos adolescentes que se atribuiu a responsabilidade autoral pelo ato infracional, em outro aspecto, questionamentos surgiram aos especialistas e profissionais que laboram de modo direto no auxílio aos adolescentes que cumpram medidas socioeducativas descritas na lei. Estes questionamentos passam a existir em razão da vasta análise das teorias que envolvem a socioeducação e suas atividades (PAES, 2008; ZANELLA, 2011).

O entendimento acerca da socioeducação veio à tona com a introdução das medidas socioeducativas contidas no ECA, legislação esta que prevê o modo estrutural das instituições de atendimento bem como seu funcionamento, deixando, todavia, um hiato no entendimento concernente a socioeducação que conseguisse passar a atuar de modo direto em intervenções reais e de promoção a evolução do adolescente. Na legislação do ECA, o substantivo socioeducação não se mostra explicito em seus 
dispositivos, mas vem adjetivado. De modo genérico, as menções legais e políticas tomam mão de expressões como "política socioeducativa", "atendimento socioeducativo", "práticas de socioeducação", "atendimento socioeducativo" dentre outros (GADOTTI, 2012). Nesse viés, em alguns estados brasileiros, por exemplo, o nome atribuído aos servidores públicos que ocupam os cargos das medidas socioeducativas consigna o adjetivo de "socioeducativo", não existindo, no entanto, um explícito conceito que o referencie.

Assim, em razão de não haver uma clara conceituação do termo, é possível que se perceba uma evidente ausência de nitidez, que em teoria é fundamentada na execução das medidas, torna mais difícil a atividade profissional de sua função. Tal hiato abre brechas para o surgimento de atividades discricionárias, ligadas a linhas de visão políticas societárias corporativistas ou pessoais, como atividades de natureza apenas punitivas, efetivadas de modo espontâneo que se ligue a experiências do indivíduo e suas crenças (ZANELLA, 2011).

Outra consequência da falta de nitidez das definições da socioeducação é a diminuição do labor socioeducativo a outros trabalhos de matéria evidentemente técnico e burocrático, em retorno a exigências de dados em observância a obediência de necessidades exteriorizadas pelo judiciário, como, encaminhar os sujeitos para o sistema socioassistencial, promover o envio de relatórios ao judiciário, fazer encaminhamento dos adolescentes para vagas de estágio, matrícula em instituições escolares, armazenar informações em sistema, dentre outros.

[...] é notório que durante as etapas evolutivas do ser humano e do enredamento dos relacionamentos com o espaço ao redor e entre os outros indivíduos, foi preciso que se garantisse, não somente os requisitos naturais para se sobreviver, mas também a evolução societária que garantisse ao indivíduo que sua humanidade fosse transmitida. Desse modo o processo educativo é inclusive uma categoria de trabalho, com suas próprias singularidades, responsável por gerar uma produtividade imaterial, como atitudes, símbolos, ideias, crenças e valores, se efetivando na edificação de indivíduos sociais e seres humanos (BRUNO, 2014, p. 68).

No âmbito educativo social têm-se as áreas da educação informal, da formal e da não formal, bem como a educação escolar geral. No âmago da atividade educativa social existe uma variedade de atividades educacionais, como, educação política, para o trabalho, educação cidadã, entre outros. Destaca-se nestas atividades, entre os 
procedimentos educativos, o comprometimento ético e político com a sociedade, em busca de se edificar um moderno mundo de possibilidades (GADOTTI, 2012).

De início, a definição de educação social, se baseia de acordo com a forma de expressão, 'o social', mesmo que pareça uma repetição, e semelhante ao destacado por Ribeiro (2006), permanecem ainda muitos questionamentos. Não obstante, a pesquisadora determina que a conceituação de educação social está intrinsecamente ligada ao de exclusão, visto surgir como resolução às preocupações: "que educação oferecer as milhares de crianças, adolescentes e adultos excluídos da e na escola; do e no emprego; da e na terra; das e nas instituições sociais?" (RIBEIRO, 2006, p. 160).

Neste sentido, o procedimento educacional social, tem como base o marxismo, em busca de que as desigualdades no meio social sejam extintas, através de uma pedagogia que se concentre na evolução da autonomia e do fortalecimento, dos setores sociais normalmente ignorados, como, as comunidades indígenas e quilombolas, adolescentes e crianças usuárias de drogas, os moradores de rua, entre outros. (ZANELLA, 2011).

Isso quer dizer, a conceituação de educação social se liga de modo premente ao de exclusão social e, por isso, as práticas educativas sociais se mostram atuantes nas atividades socioeducativas em patamar de fundamentação teórica, matérias e métodos que se requer para interagir com um meio social contundido por procedimentos de exclusão e dominação.

Não obstante, é preciso destacar que o labor da educação social, sob um aspecto analítico, não se limita a abstrair os setores de marginalização no mercado trabalhista, em projetos culturais de lazer e esporte para que se reproduza uma linha liberal de sociedade, mas para que se formem agentes com capacidade crítica, que ousem não negar o lugar na sociedade a eles relegado pela sistemática de classes, e lutem para vencer o abuso do sistema em que estão inseridos (RIBEIRO, 2006).

Sendo assim, a socioeducação se encontra no imenso âmbito da educação social, sustentando-se em uma definição mais focada no social da forma educativa, visando que os direitos humanos sejam afirmados e efetivados, engajado na autonomia e independência de cada indivíduo e seu relacionamento com o social, com a cidadania. Sabe-se que a socioeducação é norteada por ideais de fraternidade, igualdade e justiça, bem como outros, objetivando principalmente a evolução de diversas aptidões que 
permitam ao indivíduo romper e superar as condições de marginalidade, pobreza e violência marcantes para o que vive excluído socialmente (RIBEIRO, 2006).

No trabalho com o título de "Socioeducação: que prática é essa?", os pesquisadores Pinto e Silva (2014) relatam a respeito do tema que a socioeducação segue uma linha de articulação de atividades que se avizinha da educação, visto se focar em desenvolver o potencial dos adolescentes.

Mencionam ainda as referidas pesquisadoras, que a atividade da socioeducação necessita ser observada com um tratamento especial para os jovens que cumprem a medida de atendimento socioeducativo. Necessitando de uma ligação estreita com a formação de qualquer adolescente ou infante, sendo precípuo que se encontre em conjunção com a educação profissional e formal, não devendo ser reputada como menos relevante que as últimas (PINTO; SILVA, 2014).

Ainda que inicialmente tenha nascedouro no setor das medidas de socioeducação que se aplicam a adolescente em conflito com a lei, a mencionada socioeducação, em razão de seu fundamento estar na educação social, vem sendo empregada não somente nas medidas de socioeducação, mas também em outros setores. Nos dias atuais em exemplificação, a expressão é utilizada para se referir ao âmbito dos abrigos ${ }^{28}$.

Nessa linha, Guará (2010, p. 60) exemplifica que "um degrau relevante pode ser tocado, caso se defina uma expressão mais atual para abrigo, para que se nomeie de modo claro sua função na sociedade, quer dizer, a de um acolhimento, que se volta para a socioeducação". A pesquisadora ainda diz que, "para que se iniciem projetos socioeducativos no abrigo é preciso que se compreenda o potencial futuro da criança e do adolescente, bem como a assimilação de suas dificuldades e conflitos que enfrenta". (2010, p. 61).

Percebe-se então, que sua nomenclatura não se limita aos adolescentes autores de atos infracionais e as medidas de socioeducação aplicadas, ainda que tenha logrado êxito em se destacar. Partindo de um entendimento da educação social sob um aspecto transformador, a socioeducação pode ser efetivada com intervenções consistentes e atividades que consigam efetivamente promover a transformação no trajeto de evolução do indivíduo, de modo mais especial, para os adolescentes autores de atos infracionais.

\footnotetext{
${ }^{28}$ Segundo o art. 92 do ECA, refere-se às entidades que desenvolvem programas de acolhimento familiar ou institucional, adotando princípios como a preservação dos vínculos familiares e promoção da reintegração familiar; atendimento personalizado e em pequenos grupos; desenvolvimento de atividades em regime de coeducação, entre outros (BRASIL, 2016, p. 26).
} 
Neste seguimento, na apresentação do Plano Nacional de Atendimento Socioeducativo, a então ministra da Secretaria de Direitos Humanos da Presidência da República e a presidente do Conselho Nacional dos Direitos da Criança e Adolescente elencaram que

[...] O processo socioeducador é indispensável como programa de política pública para que se quite o elevado débito histórico social brasileiro com a classe dos adolescentes (que são sobretudo atingidos pela grande violência) e para que se contribua com a construção de uma sociedade mais equânime que cuida dos adolescentes de seu país (BRASIL, 2013, p. 8).

Para tanto, em relação às políticas públicas, a socioeducação se foca primordialmente aos jovens e adolescentes que foram separados de seus direitos ou mesmo que atuaram positivamente para cometer atos infracionais, se sistematizando hoje em dia como Sistema Nacional configurado e com aspectos singulares.

Observado que o processo educativo se dá em muitos ambientes e contextos - na política, nos meios de comunicação, na igreja, na escola, na vizinhança, no trabalho, na família, não se consegue limitá-lo ao setor da educação, visto sua amplitude e não se efetuam de modo estranho aos relacionamentos sociais, econômicos, políticos e culturais. E também, sob o argumento de que toda educação refletirá uma interpretação da sociedade e do mundo, fica evidente a razão de existirem tantas práticas educacionais e vieses. O processo de conscientização e estudo das conceituações educativas é elementar para que se compreenda a socioeducação, ainda que a origem do termo seja impreciso e de pouca unanimidade desses para definições discricionárias e pessoais (GUARÁ, 2010)

Em razão disso, foi proposta uma análise referente às conceituações e delimitações teóricas a respeito da socioeducação partindo de um entendimento de que o processo educativo social busca se compromissar ética e politicamente em prol da edificação de uma sociedade possível. Tal fundamentação incentiva a criação de atividade educadoras com o fito de colaborar na formação de sujeitos com visão crítica, capazes de se negarem a ficar no lugar determinados para eles na sociedade, sobretudo, romper as linhas de ética e sociedade hoje atuantes. A esse respeito, a socioeducação, estrutura-se como uma amálgama de atividades, serviços e programas que se desenvolvem por meio de inter-relação, das atividades educacionais, exigências sociais e direitos humanitários, com o fito de que se desenvolvam as potencialidades do sujeito, 
da emancipação e da autonomia, inclusive fortificar as bases éticas da vida social e seus princípios.

\subsection{O cárcere e as "celas de aula"}

Se os programas de educação já encontram diversas dificuldades na sua efetivação, em espaços de controle e privação de liberdade, a complexidade é ainda mais aguçada. Isso ocorreu basicamente por dois princípios: o adolescente/preso além de ser aluno ele é um adolescente/adulto em conflito com a lei/detento e a sala de aula é uma cela.

É muito comum as salas de aula dos presídios e unidade de atendimento socioeducativo de internação, apresentarem arquitetura prisional, com forte vigilância, cadeados nas portas (ou grades) e até mesmo a presença de agentes de segurança, dentro da sala, no momento em que as aulas são ministradas.

Além disso, a educação em unidades prisionais e socioeducativas sofrem com os preconceitos, estigmas, despreparo em alguns casos na formação dos professores, normas e regras rígidas nas unidades que descaracterizam o objetivo da educação, que é a liberdade e autonomia intelectual e atitudinal dos sujeitos. A autonomia intelectual pode ser compreendida como aquela que proporcione a decisão sobre o que estudar, ler e pensar. A atitudinal refere-se a decisão de que atitude tomar diante da vida.

A educação é direito de todos. E é com base nesse princípio legal estabelecido no Artigo 205 da CF/88 (BRASIL, 1988) que esses locais passaram a ser atendidos, com programas de formação, profissionalização e (re)socialização. De acordo com Julião (2007)

[...] A escola nos presídios tem uma enorme responsabilidade na formação de indivíduos autônomos, na ampliação do acesso aos bens culturais em geral, no fortalecimento da autoestima desses sujeitos, assim como na consciência de seus deveres e direitos, criando oportunidades para seu reingresso na sociedade (JULIÃO, 2007, 47).

O processo educativo no ambiente carcerário tem como foco a formação e a (re)socialização do encarcerado, visto como um direito basilar do indivíduo, disponível a todos aqueles que se encontram em estado de liberdade limitada. Tal educação possui como função primordial, promover a qualificação e desenvolvimento dos detentos/adolescentes, para que desse modo, consigam se integrar novamente na 
sociedade, visto que muitos destes que estudam na prisão/unidade, possuem uma trajetória pessoal de abandono e vulnerabilidade, se deparando com o obstáculo da violência e das drogas, e inclusive, parte destes internados não possuem nenhum nível de estudo. A educação pode ser vista como um caminho que propõe o resgate da dignidade e a formação da cidadania.

A educação é elemento integrante do programa (re)socializador e o Estado tem por responsabilidade a criação de estratégias e propostas para o sistema penal e socioeducativo, com o propósito de que sejam criadas políticas públicas para serem edificadas em prol dos sujeitos residentes do ambiente carcerário, desenvolvendo a educação neste sistema.

O sistema prisional como hoje é conhecido, é uma criação contemporânea. Ainda que o exercício de se prender as pessoas seja tão antigo quanto a própria sociedade, apenas no século XIX é que surgiram estudiosos que destacam a premência de se efetivar a humanização das penas ligadas a medidas prisionais (ONOFRE, 2007).

Nos tempos antigos, a sociedade acreditava que os indivíduos presos não deveriam possuir nem o direito à vida, quiçá o de ser educado. Garantia-se unicamente a este sujeito o direito de ser punido e castigado, visto que eles nunca seriam concebidos para retornar ao convívio social. Araújo e Leite (2013) afirmam que a gênese das prisões remete aos primórdios da humanidade, através das penalidades corpóreas, que eram as medidas utilizadas para corrigir as infrações.

No Brasil, o modelo penal atual foi estabelecido e adaptado dos sistemas penitenciários americanos e europeus, durante o final do século VIII até início do século XIX. O primeiro cárcere imperial foi denominado de Casa de Correção da Corte, fundado no Rio de Janeiro, meio da Carta Régia de 8 de Julho de 1769 e considerado um passo fundamental para fazer do novo império um lugar civilizado. Nesta época, por ainda está em vigência no Brasil a escravidão, uniu-se o suplício, a prisão e o trabalho forçado até o final do século XIX (DUARTE, 2013; ARAUJO, 2013).

Não obstante com a evolução dos tempos, o conceito de pena foi mudando, primeiro para "pena-castigo", depois "pena-prisão", seguindo para "pena-defesa" até o momento em que a educação é inserida como forma de tratamento dos detentos, criando assim a "pena-educação" (DUARTE, 2013).

A busca por soluções que reduzissem os elevados índices de crimes se elevou grandemente e o governo passou a estabelecer propostas de reintegração social para os 
detentos, proposta esta que foi por meio da educação não formal e formal, as que foram mais eficazes na redução dos índices criminais. Para Haddad (2010)

[...] a imagem do iceberg tem sido utilizada com frequência para fazer a distinção entre educação escolar e não escolar. A parte visível do iceberg seria a educação escolar, aquela que se confunde com o próprio termo educação e que é valorizada socialmente como um direito humano e fator de conquista de cidadania. A parte submersa, com um volume maior e de sustentação da parte visível, normalmente não vista pelo senso comum, denominamos educação não escolar (HADDAD, 2010, p. 117).

O procedimento educativo chegou ao sistema prisional no país no ano de 1950, buscando se tornar mais uma ferramenta de reintegração social para os indivíduos residentes no cárcere (SANTOS, 2002). Mas foi no ano de 1984, por meio da Lei de Execuções Penais, que diversas mudanças ocorreram, vindo a educação no sistema penitenciário ser atividade obrigatória. A Lei de Execução Penal determina nos artigos 17 a 21 as seguintes diretrizes:

Art. 17. A assistência educacional compreenderá a instrução escolar e a formação profissional do preso e do internado.

Art. 18. O ensino de $1^{\circ}$ grau será obrigatório, integrando-se no sistema escolar da Unidade Federativa.

Art. 18-A. O ensino médio, regular ou supletivo, com formação geral ou educação profissional de nível médio, será implantado nos presídios, em obediência ao preceito constitucional de sua universalização.

$\S 1$ o O ensino ministrado aos presos e presas integrar-se-á ao sistema estadual e municipal de ensino e será mantido, administrativa e financeiramente, com o apoio da União, não só com os recursos destinados à educação, mas pelo sistema estadual de justiça ou administração penitenciária.

$\S 20$ Os sistemas de ensino oferecerão aos presos e às presas cursos supletivos de educação de jovens e adultos.

§ 30 A União, os Estados, os Municípios e o Distrito Federal incluirão em seus programas de educação à distância e de utilização de novas tecnologias de ensino, o atendimento aos presos e às presas. Art. 19. O ensino profissional será ministrado em nível de iniciação ou de aperfeiçoamento técnico.

Parágrafo único. A mulher condenada terá ensino profissional adequado à sua condição.

Art. 20. As atividades educacionais podem ser objeto de convênio com entidades públicas ou particulares, que instalem escolas ou ofereçam cursos especializados.

Art. 21. Em atendimento às condições locais, dotar-se-á cada estabelecimento de uma biblioteca, para uso de todas as categorias de reclusos, provida de livros instrutivos, recreativos e didáticos (BRASIL, 1984, p. 02). 
A educação no ambiente penal veio à tona com o fito de efetivar a reintegração dos indivíduos que se encontravam privados da convivência social, sem maiores perspectivas de como viver, visto que foi por meio de atuações de instituições do governo em conjunto com as secretarias de educação estadual, que se conseguiu iniciar com tal expansão em muitos lugares do país, objetivando a (re)socialização dos apenados por meio da Educação. O estudioso Foucault (2008) relata que "a educação do detento é, por parte do poder público, ao mesmo tempo uma precaução indispensável no interesse da sociedade e uma obrigação para com o detento".

No que tange a implementação da educação em ambientes de privação de liberdade, Otioboni (2007) relata que

\begin{abstract}
[...] No dificultoso percurso para se efetivar a Educação no seio da instituição prisional, muitos problemas com a introdução da educação no meio carcerário foram localizados, visto que nem todos os entes governamentais anuíram imediatamente em implementar a educação carcerária, isto se deu pela ausência estrutural de certos estabelecimentos prisionais não possuírem poder monetário para instituir a unidade escolar em sua estrutura e nem servidores com capacitação para a segurança dos professores, outro problema localizado foi o pouco quórum de alunos em sala, visto que inúmeros detentos desejavam estudar, mas outros apenados que não possuíam o mesmo desejo, os impedia não acreditando no sistema proposto (OTIOBONI, 2007, p. 135)
\end{abstract}

Entende-se que a promoção da educação na prisão possui como incentivadores a atividade conjugada dos estados em consonância com a sociedade, para que se garanta um direito básico aos indivíduos que se encontram limitados em sua liberdade. No entanto, para que tal processo ocorra de modo garantido, os órgãos do governo precisam edificar um ambiente propício para o suprimento das carências dos internos, bem como executar a qualificação dos docentes para que consigam laborar de modo mais eficaz e criar estratégias de ensino para que se trabalhe com essa linha de indivíduos em específico.

Segundo Graciano (2010) a atuação da sociedade civil no contexto carcerário é primordial para que se promova o adequado controle social sobre a ação de repressão do estado, realizando atos educativos ou não, os órgãos possuem como obrigação o ato de trazer à tona para todos a situação que se encontra os apenados no interior da prisão, tornando basilar o atendimento dos direitos humanos básicos ao ser. As pessoas precisam crer que um indivíduo que infringiu a lei pode se transformar e tomar um caminho diferente para a vida. Precisam acreditar que a (re)socialização não é utópica e que existem mecanismos eficientes para este caminho. 
A instituição escolar busca ser reputada como um local de comunicação, de interação pessoal, lugar em que o apenado pode se despir de suas falácias, tornando assim, fácil o relacionamento entre si e os outros, ao passo que se ofertará ao estudante facilidades para que ele edifique sua própria identidade e reveja seu patamar perdido de cidadão (ONOFRE, 2007).

$\mathrm{O}$ procedimento educativo tem como enfoque produzir estratégias e metodologias educativas que se comprometam com a liberação, (re)socialização e humanização dos internos, buscando investigar as atividades de educação no interior da instituição carcerária.

Segundo Freire (1983), não é satisfatório entender que a educação jamais se manterá neutra, mas conseguir diferenciar as muitas linhas a se seguir, visto que a instituição escolar existe sob uma visão histórica em um determinado tempo e meio social, e para que seja compreendida é relevante que se observe a forma como o poder edifica a sociedade e em prol de quem se está trabalhando.

O meio social, em conjunto com algumas instituições do governo precisam ofertar políticas públicas que consigam fazer a inserção de tais internos ao convívio em sociedade, pois é dever do governo promover a proteção dos indivíduos que foram restringidos em seus direito de liberdade, a educação e a saúde, para que no momento em que tiverem sua liberdade restituída consigam retornar ao convívio social digno.

\section{3 (Re)socialização de adolescentes em conflito com a lei}

$\mathrm{O}$ adolescente em conflito com a lei corresponde a pessoa, entre doze e dezoito anos de idade, que tenha cometido algum ato infracional. Tais atos são análogos as condutas de crimes ou contravenções penais, praticados pelas pessoas maiores de idade, porém o ECA, que consiste em uma legislação precursora nas normativas de direitos humanos, não utiliza a expressa crime ao se referir a tais sujeitos. Pelas suas práticas, esses adolescentes também podem ser denominados de autores de ato infracional. (BRASIL, 2016).

Como já exposto, o ECA assegura em seu artigo 101, um rol de medidas protetivas destinadas às crianças que porventura cometerem atos infracionais. Aos adolescentes, são destinadas legalmente, medidas socioeducativas, prevista no artigo 112, da referida lei. A medida aplicada ao adolescente levará em conta a sua capacidade de cumpri-la, as circunstâncias e a gravidade da infração. (BRASIL, 2016). 
A Lei 12.594/12, que instituiu o Sinase, descreve quais são os objetivos das medidas socioeducativas, sendo apresentadas nos três incisos do parágrafo $2^{\circ}$, do artigo primeiro:

I - a responsabilização do adolescente quanto às consequências lesivas do ato infracional, sempre que possível incentivando a sua reparação; II - a integração social do adolescente e a garantia de seus direitos individuais e sociais, por meio do cumprimento de seu plano individual de atendimento; $\mathrm{e}$

III - a desaprovação da conduta infracional, efetivando as disposições da sentença como parâmetro máximo de privação de liberdade ou restrição de direitos, observados os limites previstos em lei.

$\S 3^{\circ}$ Entendem-se por programa de atendimento a organização e o funcionamento, por unidade, das condições necessárias para o cumprimento das medidas socioeducativas.

$\S 4^{\circ}$ Entende-se por unidade a base física necessária para a organização e o funcionamento de programa de atendimento.

$\S 5^{\circ}$ Entendem-se por entidade de atendimento a pessoa jurídica de direito público ou privado que instala e mantém a unidade e os recursos humanos e materiais necessários ao desenvolvimento de programas de atendimento. (BRASIL, 2016, p. 89).

O ECA deixa explícito que seu objetivo é garantir a proteção integral, sem prejuízo algum, de todos os direitos fundamentais inerentes à pessoa humana, que gozam as crianças e adolescentes. (BRASIL, 2016). Contudo, o texto não traz explicitamente as expressões socialização, ressocialização, integração social ou reintegração social.

Da mesma forma, a Lei 12.594/12, que regulamenta a execução das medidas socioeducativas destinadas a adolescente que pratique ato infracional, também não traz em seu texto, em momento algum, as expressões socialização, ressocialização e reintegração social. O texto faz menção, por duas vezes apenas, da expressão integração social, no artigo $1^{\circ}, \S 2^{\circ}$, inciso II e no artigo 54, inciso III. (BRASIL, 2016).

É importante que seja devidamente expresso aqui o entendimento que esta pesquisa tem sobre os termos socialização e ressocialização, que no texto será transcrito como (re)socialização. Assim, serão apresentados as principais definições teóricas quanto ao processo de socialização e ressocialização e o motivo desta pesquisa se apropriar do termo (re)socialização, levando também em consideração o que diz a literatura prisional.

No que tange a socialização, serão apresentados alguns conceitos trazidos pela literatura clássica, defendidos por Durkheim, Beger e Luckmann, bem como serão 
expostos os principais conceitos sobre o tema, defendidos pela visão contemporânea, estudados principalmente por François Dubet e Bernard Lahire.

Para a ressocialização, as principais considerações serão expressas mediante a literatura prisional, que utiliza com frequência este termo. Alguns pontos relevantes serão expostos, como: as controvérsias com o uso da expressão; a ressocialização a luz da Lei de Execuções Penais e a posição realista e idealista da ressocialização.

Para a sociologia da educação, em seus estudos clássicos, a família e a escola correspondem aos dois espaços de socialização tradicionais. Durkheim (1978, p. 41) atribuindo à educação o papel socializador, discorre que

[...] a educação é a ação exercida pelas gerações adultas, sobre as gerações que não se encontrem ainda preparadas para a vida social; tem por objetivo suscitar e desenvolver na criança, certo número de estados físicos, intelectuais e morais, reclamados pela sociedade política, no seu conjunto, e pelo meio especial, a que a criança particularmente, se define (DURKHEIM, 1978, p. 41).

O papel da escola neste contexto é de fundamental importância, constituindo numa socialização metódica das novas gerações. Souza (2009, p.76) analisando o entendimento de Durkheim (1978), destaca dois motivos principais:

[...] um deles é que caberia a ela desenvolver as aptidões individuais, permitindo a cada um se adequar à divisão do trabalho posto que a educação doméstica não seria mais suficiente para essa exigente tarefa. O outro se relaciona ao importante papel da escola no processo de socialização, criando e difundindo novas idéias que reforçassem as estruturas da sociedade, por exemplo, uma moral laica e racional que pudesse ocupar o lugar que a religião (religere, religação, ligação compacta) outrora havia ocupado (SOUZA, 2009, p.76).

Assim, conforme Durkheim (1978), socializar é o mesmo que educar. Disto se depreende que a educação, no processo de socialização, tem por objeto formar o ser social, ou seja, "criar no homem um ser novo" (1978, p. 42). Para este autor, todos os sujeitos estão integrados a sociedade, o que não significa que todos estejam dentro do mesmo contexto ou dos valores pregados pela sociedade capitalista, em que o homem é valorizado pelo que tem e pelo que produz.

Esse novo ser criado, no entendimento de Durkheim, é constituído da unidade entre indivíduo e sociedade, decorrentes de uma educação normativa e moral. O processo de interiorização das regras de comportamento moral não se constituiria de modo arbitrário, mas como uma fase civilizatória que promove liberdade. Portanto, a 
educação familiar e escolar seriam as responsáveis por exercer influência total na personalidade da pessoa. Esta é complementar a familiar, pois não tem caráter privado e doméstico e sim, responsável pela formação de indivíduos morais e éticos, comprometidos com os ideais públicos. (SETTON, 2005).

Em obras mais recentes, utilizadas como referências na compreensão do processo de socialização, surgem os autores Berger e Luckmann. Na obra A construção social da realidade (1983) eles distinguem e conceituam o processo de socialização em dois momentos: socialização primária e a socialização secundária.

Para esses autores, a primária corresponde a primeira socialização que a pessoa experimenta na fase da infância e assim torna-se membro da sociedade. É quando ocorre a internalização da realidade mediante as relações sociais que vão se formando. A família e as pessoas mais próximas correspondem ao grupo social responsável pela estruturação da vida psíquica da criança e é onde estabelece as primeiras relações sociais. Ainda nessa fase, há uma imersão da criança em um mundo que é só dela, único existente e concebível. (BERGER; LUCKMANN, 1983; SETONN, 2005).

A socialização secundária acontece quando a criança atinge ou inicia o período escolar, envolvendo outros agentes no processo social, como os professores e os colegas da escola. Os autores afirmam que nessa fase a criança traz consigo um mundo que acredita ser só seu (único e verdadeiro) e pode até passar por momentos de crise ao ser exposta a outras realidades. Definem esse momento como a interiorização de submundos institucionais especializados. Com isso, afirma que a escola e os professores são os agentes sociais responsáveis pela reafirmação da realidade subjetiva da criança. (BERGER; LUCKMANN; 1983, SETONN, 2005).

Na contemporaneidade, alguns autores como François Dubet e Bernard Lahire buscam compreender as novas experiências de socialização. O processo de socialização das sociedades atuais, de acordo com Setonn (2011) é um espaço plural de referências indenitárias variadas.

Esta autora, ao analisar a obra de Dubet (1996), intitulada Sociologia da experiência, traz uma reflexão sobre o questionamento levantado por ele, em que não é mais possível compreender a ação social a partir do modelo clássico, ou seja, o modelo que caracteriza o ator individual pela interiorização do social, sendo sua ação a concretização das normas de um conjunto social integrado (SETONN, 2005). 
Dubet (1996) sugere a noção de experiência social, que segundo esse autor, pode auxiliar na compreensão de condutas sociais que não se limitam a aplicações de códigos interiorizados (modelo clássico). As condutas seriam organizadas por princípios heterogêneos, ou seja, várias lógicas de ação que remetem a várias lógicas do sistema social. Na visão desse autor, a experiência social é uma forma de construir o mundo (DUBET, 1996; SETONN, 2005).

Para Setonn (2005) ao sintetizar o conceito de socialização atribuído a obra de Dubet (1996) discorre que

[...] $\mathrm{O}$ indivíduo não está inteiramente socializado, não porque lhe preexistam elementos "naturais" e irredutíveis, mas porque a ação não tem unidade, não é redutível a um programa único. Segundo o autor, existe alguma coisa de inacabado e de opaco na experiência social do indivíduo contemporâneo, porque não há adequação absoluta entre a subjetividade do ator e a objetividade do sistema. Não existe uma socialização total, mas se processa uma espécie de separação entre a subjetividade do indivíduo e a objetividade de seu papel. E essa socialização não é total, não porque o indivíduo escape do social, mas porque sua experiência se inscreve em registros múltiplos e não congruentes (SETONN, 2005, p. 343)

Com entendimento semelhante, no que tange a diversidade de experiências socializadoras, Lahire (2002), que tem como tema principal de seus estudos o processo de socialização e a sociologia das disposições sociais e culturais, defende a idéia de que o indivíduo vive experiências variadas e/ou contraditórias e por isso não ocupa posição semelhante em todos os espaços (LAHIRE, 2002).

Para este autor, a família, a escola, a comunidade e as diferentes instituições culturais onde a criança é inserida e lavada a conviver, não apresentam situações homogêneas e em alguns casos pode até apresentar características contraditórias, no que tange aos princípios da socialização. As vivências nesses locais não são sinteticamente somadas simplesmente. Além disso, é cada vez mais precoce o contato da criança com outros universos (pluralidade de mundos), além da família, o que este autor chamou de contextos sociais e não equivalentes. O sujeito, nesse processo socializador é considerado múltiplo e resultado de experiências precoces em contextos sociais diversos. (LAHIRE, 2002; SETONN, 2005; SETONN, 2011).

Para Nogueira (2013) ao sintetizar o conceito de socialização atribuído na obra de Lahire (2002) propõe

[...] um olhar mais atento em relação à diversidade de experiências de socialização a que um mesmo ator é submetido (mais ou menos 
precoces, intensas, sistemáticas e coerentes entre si), ao caráter plural ou mesmo contraditório das disposições assim constituídas (mais ou menos fortes, estáveis e transferíveis) e à multiplicidade dos contextos de ação (nem sempre passíveis de serem descritos como um campo). Fundamentalmente, o argumento de Lahire é de que é necessária uma análise empírica mais detalhada, por um lado, dos processos de socialização por meio dos quais as disposições são incorporadas e, por outro, dos contextos de ação, nos quais parte do passado incorporado é reativada. Segundo ele, a Sociologia, em geral, [...], tendem a evocar de maneira abstrata os processos de incorporação do passado pelos atores e de uso desse passado em situações práticas de ação, sem investigá-los empiricamente em toda sua complexidade (NOGUEIRA, 2013, p. 1).

Obviamente, os estudos contemporâneos são extensos e exigem um aprofundamento maior nas articulações que permitem chegar até seus conceitos e aos posicionamentos dos autores referidos aqui. Mas é possível afirmar que, a visão contemporânea se caracteriza pela diversidade de princípios de ações e observam um afastamento paulatino entre a coerência das práticas dos atores e os espaços institucionais em que circulam (SETUNN, 2005).

Partindo para o entendimento do termo ressocialização, no qual Vienne (2005) classifica como psicossocial, nota-se que é comumente usado pela literatura prisional e também com certa frequência, no vocábulo do senso comum dos gestores políticos dos sistemas escolares, especificamente aos estudantes que apresentam desinteresse pelo ambiente escolar.

A proposta aqui ao elucidar o entendimento sobre a ressocialização não pretende trazer à tona as críticas e discussões que pairam sobre a eficácia e eficiência de suas políticas e práticas no ambiente da sociologia. O intuito sim é forjar o entendimento inserido no contexto que o termo é utilizado no sistema de ensino, partindo dos pressupostos clássicos e contemporâneos da sociologia, em que o ser humano é um ser social e é constituído principalmente do processo educativo. A proposta também é associar o tema aos espaços de privação de liberdade para auxiliar numa melhor compreensão do que propõe o objetivo desta pesquisa.

O conceito de ressocialização apresenta em torno de si, discussões que levantam polêmicas quanto à finalidade, ao serem analisadas em consonância com os ideais legislativos. O entendimento aqui vai além legislação destinada a adolescentes em conflito com a lei, assistidos pelo ECA. Na Lei de Execução Penal (LEP) brasileira Lei número 7.210, de 11 de julho de 1984 há o enfrentamento de obstáculos na 
aplicação de alguns de seus dispositivos. Esta lei não expressa em seu texto a expressão ressocialização, mas em seu artigo primeiro apresenta seu objetivo, que consiste em "efetivar as disposições de sentença ou decisão criminal e proporcionar condições para a harmônica integração social do condenado e do internado" (BRASIL, 1984, p.1).

Desde então, tanto a LEP quanto as leis destinadas a adolescentes em conflito com a lei, buscam garantir a dignidade da pessoa humana, durante o cumprimento de suas penas/medidas socioeducativas e, consequentemente, garantir as condições necessárias para a reintegração social. A reintegração social é entendida como o retorno à convivência em sociedade. (BRASIL, 1984; ANDRADE, 2015).

Surgem alguns embates doutrinários quanto à funcionalidade da ressocialização aplicada em espaços de privação de liberdade. Há um entendimento entre aqueles que a defende que as atenções básicas (assistência psicológica, educacional, religiosa, social, material e à saúde) prestadas aos presos/internos/adolescentes em conflito com a lei, contribuem na promoção de sua reinserção a sociedade. Para Andrade (2015) os adeptos da criminologia crítica rechaçam a ressocialização, pois na visão deles, viola o livrearbítrio e a autonomia do sujeito. Feito isso, esses sujeitos perdem a sua personalidade, suas ideologias e seus valores, para se ajustarem aos valores tidos como legítimos.

Baratta (2007) traz a lume alguns apontamentos quanto à realidade atual das prisões. Para esse autor, elas estão distante daquilo que de fato é necessário para o cumprimento das funções de ressocialização, o que pode ser comprovado pelos altos índices de reincidência criminal e os efeitos que a privação de liberdade provoca na vida dos sujeitos. Mas dessa realidade não se depreende um consenso quanto aos rumos que deveriam ser dados as unidades prisionais. Assim, Baratta (2007) tece seus estudos sobre dois pólos: o realista e o idealista.

A ressocialização, sob o prisma realista, conforme Baratta (2007) traz o reconhecimento científico que a unidade prisional não é capaz de ressocializar, mas neutralizar o delinquente; que o cumprimento da pena não corresponde em absoluto a uma oportunidade de reintegrar o sujeito a sociedade, mas um sofrimento imposto como castigo.

Ao expor sob a visão idealista, Baratta (2007) assegura que aqui estão os que permanecem na defesa da prisão como lugar e caminho para a ressocialização, como um espaço de prevenção especial positiva. Os que defendem a posição idealista acreditam 
que é preciso manter a ressocialização, pois seu abandono contribuiria para fortalecer o caráter exclusivamente punitivo da pena. (BARATTA, 200; ANDRADE, 2015).

Esse autor discorda dos dois posicionamentos (realista e idealista). Para Baratta (2007) a prisão não é capaz de promover a ressocialização e o que produz de fato são obstáculos para seu real objetivo. Mas, compreende que o intuito da prisão, de promover a reintegração do apenado a sociedade, não deve ser descartada. Ao contrário, precisa ser reinterpretada e reconstruída.

Baratta (2007, p. 2) defende a máxima que "a melhor prisão é sem dúvida, a que não existe", pois não possui a função de mudar os sujeitos e os ressocializá-los. Mas acredita ser possível buscar a reintegração social, apesar dela (prisão). Para isso sugere que, as políticas e ações voltadas para esses sujeitos, forneçam melhores condições de vida para os apenados, enquanto restrita a sua liberdade. Defende ainda a abertura da prisão a sociedade e, mutuamente, que a sociedade também se conecte a prisão e assuma a sua responsabilidade, pois não se pode segregar pessoas e, simultaneamente, reintegrálas. Complementa suas considerações ao dizer que

[...] os muros da prisão representam uma barreira violenta que separa a sociedade de uma parte de seus próprios problemas e conflitos. Reintegração social (do condenado) significa, antes da modificação do seu mundo de isolamento, a transformação da sociedade que necessita reassumir sua parte de responsabilidade dos problemas e conflitos em que se encontra "segregada" na prisão. (BARATTA, 2007, p. 3).

Considera ainda que seja feita uma reinterpretação dos conceitos de tratamento e ressocialização, visto que eles denotam ao apenado uma idéia de objeto passível a ações externas e não de sujeito de direito. Defende que as palavras tratamento e ressocialização podem ser interpretadas como o processo de reintegração "por meio da" prisão, a qual Baratta (2007) lança mão. Não é possível, para este autor, inferir dessas expressões uma idéia de igualdade entre as partes envolvidas (detento e instituição; prisão e sociedade) e um processo de comunicação entre elas. Ele acredita que o processo ocorra "ainda que" na prisão, ou seja, apesar das condições desfavoráveis é possível se pensar um projeto, com direitos ao apenado, que vá ao encontro de conteúdos possíveis, sem uma postura passiva diante do sistema. Ele sugere que as palavras tratamento e ressocialização sejam substituídas pelas palavras benefício e reintegração social, respectivamente. Mesmo porque, além de todas as atribuições dadas pelo autor, a palavra tratamento ainda denota a ideia de que o sujeito está doente. (BARATTA, 2007). 
Entende-se neste trabalho que, mesmo o adolescente em conflito com a lei não correspondendo aos padrões éticos e morais impostos por nossa sociedade, e em algum momento da sua vida os rompeu ao praticar um ato ilícito, ainda está em um contínuo processo de socialização, institucionalizado ou não (visão contemporânea). Dentro das unidades são estabelecidas relações sociais (adolescente-adolescente, adolescenteprofessor, adolescente-agente socioedutativo). Até aqueles que foram privados do convívio direto com seu núcleo familiar na socialização primária ou não tiveram a oportunidade e acesso à escola na fase secundária devem ser entendidos como socializados, pois sempre estiveram inseridos em algum contexto social - não cabendo aqui nenhum julgamento quanto a licitude desse contexto.

Da mesma forma, não é pejorativo ou inadequado o termo ressocialização, visto que a usualidade de tal expressão foi apropriada pela literatura prisional e pela corrente que defende o posicionamento idealista. Ressocialização como um dos atributos da educação, visto que esta é um processo constante e estamos sempre nos educando. (BARATTA, 2007).

Nesse viés, entende-se que o adolescente em conflito com a lei, ou um preso, estão privados do convívio social (fora da unidade de internação/prisional) e a fase de cumprimento da medida socioeducativa ou da pena deve ser vista como o caminho de preparação para integrá-los novamente ao convívio social, torná-los úteis a si mesmos, a família e sociedade. Para Vienne (2005, p. 645) a ressocialização possui um fundo moral que sustenta a ideia de "anular a má socialização" e reconstruir sobre esta uma nova socialização harmoniosa e em sintonia com os padrões sociais estipulados.

Não cabe aqui nenhum julgamento sobre o que seria de fato uma má socialização. Esta pesquisa defende a ideia de que cada sujeito está inserido em um contexto social e quase sempre vulnerável a sua realidade. O que seria então boa ou má socialização estaria ligado as oportunidades que cada um teria dentro do seu contexto. Essas oportunidades dependem muito mais de ações públicas por parte do Estado e sociedade. O que sabemos que não acontece de forma igual para todos. Assim, o conceito de exclusão social seria muito mais apropriado se entendêssemos que, nas palavras de Campos e Campos (2013, p. 189) "não existe exclusão, o que existe são formas precárias, instáveis e marginais de inclusão".

Isto posto, é possível concluir que as unidades prisionais e as unidades de atendimento socioeducativo de internação, não são, por si só, capazes de (re) 
socializarem os sujeitos inseridos em seu contexto. Mas é possível pensar em ações "a partir de" cada um desses locais. Assegurando condições adequadas e de respeito a dignidade de todos os sujeitos, promovendo acesso à educação de qualidade, profissionalização e todo tipo de assistência que se fizer necessária. Quando se fala em reintegrar o sujeito a sociedade fica implícito o papel que esta passa a ter nesse processo. A sociedade precisa estar em harmonia com as ações do Estado para a (re) socialização daqueles que ela mesma excluiu. 


\section{CAPÍTULO 04}

\section{CAMINHOS METODOLÓGICOS: A PESQUISA, O LOCAL E OS SUJEITOS ENVOLVIDOS}

No primeiro momento deste texto será feita uma breve descrição sobre Pesquisa Educacional, os principais problemas relacionados às pesquisa e sobre a abordagem qualitativa de pesquisa. Em seguida, será apresentada a pesquisa em análise, sendo exposto seu objetivo geral, bem como os específicos, a justificativa e o problema que deu origem a mesma. Por fim, a que tipo de investigação se refere, seu rigor científico, os instrumentos que serão utilizados, os mecanismos que constituirão a coleta dos dados e a análise dos mesmos, até chegar ao seu produto.

\subsection{A escolha da metodologia de pesquisa}

Por se tratar de uma investigação no campo educacional é interessante inicialmente ressaltar alguns pontos relevantes sobre esta área de pesquisa. Para Gatti (2007) o principal objetivo em se fazer pesquisa é construir o que entendemos por ciência, trazendo a lume, através de um conjunto estruturado de conhecimentos, aquilo que não está claro ou até mesmo caótico.

O pesquisador sempre transitará às margens da incerteza, visto que não há conhecimento absoluto e definitivo. Gatti (2007, p.10) ratifica que "os conhecimentos são sempre relativamente sintetizados sob certas condições ou circunstâncias, dependendo das teorias, dos métodos e das temáticas que o pesquisador escolhe para trabalhar".

No que tange ao tema escolhido para trabalhar é evidente que o pesquisador traga consigo alguns valores, aptidões, interesses e princípios os quais ele esteja vinculado. Alguns autores, como Ludke e Andre (1986), acreditam que isso possa ser um ponto positivo visto que contribui no desenvolvimento da investigação. Investigar algo na qual se tem um mínimo de ligação ou aproximação facilita o processo de coleta e análise de dados.

Outro ponto importante na pesquisa em educação são os dados em que serão trabalhados. Estes podem ser entendidos, de acordo com Ludke e Andre (1986) como todo o material obtido durante a pesquisa, tendo como exemplo os relatos de 
observações, as transcrições das entrevistas, os diálogos, os questionários, as discussões, as análises dos documentos, dentre as outras informações disponíveis.

Destarte, estes dados surgem diante da análise de um determinado problema na qual o pesquisador se compromete a entendê-lo. Ludke e Andre (1986, p.1) acreditam que "para se realizar uma pesquisa é preciso promover o confronto entre os dados, as evidências, as informações coletadas sobre determinado assunto e o conhecimento teórico acumulado a respeito dele".

A Pesquisa Educacional possui características singulares na produção do seu saber e também rigorosas como todo campo científico. O professor Bernard Charlot em artigo publicado na Revista Brasileira de Educação no ano de 2006 elucida pontos importantes sobre a identidade, as especificidades e os desafios dos profissionais que atuam em pesquisas nessa área de saber.

Para Charlot (2006) no campo das pesquisas em educação circulam conhecimentos, práticas e políticas que por vezes são de origem diversas. Acrescenta ainda que "é um campo de saber fundamentalmente mestiço, em que se cruzam, se interpelam e, por vezes, se fecundam, de um lado, conhecimentos, conceitos e métodos originários de campos disciplinares múltiplos, e, de outro lado, saberes, práticas, fins éticos e políticos" (CHARLOT, 2006, p. 9).

Em consonância ao exposto, Gatti (2007) complementa que

[...] A pesquisa educacional, tal como ela vem sendo realizada, compreende, assim, uma vasta diversidade de questões, de diferentes conotações, embora todas relacionadas complexamente ao desenvolvimento das pessoas e das sociedades. Ela tem abrangido questões em perspectivas filosóficas, sociológicas, psicológicas, políticas, biológicas, administrativas, etc (GATTI, 2007, p. 13).

Apesar de sua vasta contribuição no campo científico, alguns autores ao analisarem a pesquisa em educação no Brasil, acreditam que há pouco impacto destas sobre as práticas, sobretudo pelo desconhecimento da discussão teórico-metodológico, sendo este fator um dos principais problemas (ALVES-MAZZOTTI, 2003).

Alves-Mazzotti (2003, p. 34) elenca como os principais problemas relacionados às pesquisas, a pobreza teórico-metodológica nas abordagens dos temas de pesquisa, com um grande número de estudos puramente descritivos; a pulverização e irrelevância dos temas escolhidos; a adoção acrítica de modismos na seleção de quadros teóricosmetodológicos; a preocupação com a aplicabilidade imediata de resultados e por fim a divulgação restrita dos resultados e pouco impacto sobre as práticas. 
A pesquisa Formação e (Re)socialização de Adolescentes em conflito com a lei: Práticas e Políticas Educacionais no Centro Socioeducativo de Unaí - CESUN é classificada como uma em educação de abordagem qualitativa. Seus métodos de coleta de dados passam pela entrevista e questionário.

No que tange a abordagem qualitativa em pesquisa educacional, Bogdan e Biklen (1982) apresentam cinco características principais, sendo estas: o ambiente natural como sua fonte direta de dados e o pesquisador como o principal instrumento; os dados coletados são predominantemente descritivos; a preocupação com o processo é muito maior do que com o produto; o significado que as pessoas dão as coisas e à sua vida são focos de atenção especial pelo pesquisador e a análise dos dados tende a seguir, no entendimento desses autores, um processo indutivo.

Nestes vieses apresentados por Bogdan e Biklen (1982) é possível inferir que há na pesquisa qualitativa uma ligação direta e prolongada do pesquisador com o ambiente e a situação que está sendo analisada, através do trabalho de campo. Para estes autores, todo estudo qualitativo é também naturalístico, pois os problemas são estudados no ambiente em que eles ocorrem naturalmente.

$\mathrm{Na}$ pesquisa qualitativa, todos os dados da realidade pesquisada, até os supostamente triviais, devem ser considerados importantes. Quando os autores Bogdan e Biklen (1982) afirmam que os dados coletados são predominantemente descritivos é porque todo material obtido nessas pesquisas são ricos em descrições de pessoas, situações e acontecimentos; transcrições de entrevistas, questionários e depoimentos e o uso frequente de citações para subsidiar os apontamentos que vão surgindo ao longo do trabalho.

É muito importante ter a clara percepção que a preocupação com o processo deva ser maior do que o produto. Nisto está um dos grandes desafios no ato de pesquisar em espaços de controle e privação de liberdade. Para Dias, Onofre, Teixeira e Conceição (2014, p. 232) a prática da pesquisa com sujeitos nas condições referidas deve acontecer com os participantes e não sobre eles, implicando o "reconhecimento da voz do outro" e a sua óptica sobre os objetivos. Estes autores ainda acrescentam

[...] O pesquisar com e não pesquisar sobre jovens e adultos em privação de liberdade tem como pressuposto a dialogicidade, de modo a priorizar que esses jovens e adultos são seres concretos e históricos, são sujeitos que pensam autenticamente, sujeitos criativos, sujeitos que reconhecem a sua vocação ontológica de ser mais e de se humanizarem, em outras palavras, pessoas inconclusas e conscientes de suas inconclusões (DIAS et al., 2014, p. 233). 
Concomitantemente, isso vai ao encontro de outra característica da pesquisa qualitativa, exposta por Bogdan e Biklen (1982), quanto ao significado que as pessoas dão as coisas e à sua vida são focos de atenção especial pelo pesquisador. A perspectiva dos participantes, que inclusive é um dos objetos desta pesquisa, deve ser considerada, afim de permitir trazer a lume toda a dinâmica das situações em que estão sujeitos.

A pesquisa qualitativa, segundo Bogdan e Biklen (1982) requer a obtenção de dados descritivos, adquiridos através do contato direto do pesquisador com a situação estudada e por isso a análise dos dados tende a seguir um processo indutivo. Na medida em que os dados são inspecionados, com o cuidado de retratar a perspectiva dos participantes, vão se consolidando as abstrações coletadas.

Para González Rey (2015) a epistemologia qualitativa,

[...] defende o caráter construtivo interpretativo do conhecimento, o que de fato implica compreender o conhecimento como produção e não como apropriação linear de uma realidade que se nos apresenta. A realidade é um domínio infinito de campos inter-relacionados independente de nossas práticas; no entanto, quando nos aproximamos desse complexo sistema por meio de nossas práticas, as quais, neste caso, concernem à pesquisa cientifica, formamos um novo campo de realidade em que as práticas são inseparáveis dos aspectos sensíveis dessa realidade (GONZÁLES REY, 20015, p. 5).

O problema da pesquisa é de natureza científica quando envolve variáveis que podem ser tidas como testáveis (GIL, 2002). Sendo assim, o problema partiu da seguinte indagação: como as práticas educacionais e as diretrizes políticas educacionais contribuem no processo de formação e (re)socialização de adolescentes, atores de ato infracional, submetidos à Medida Socioeducativa de internação no CSEUN, sob o olhar destes, em junho de 2017 ?

O projeto tem como principal objetivo analisar, sob a percepção de adolescentes em restrição de liberdade, que cumprem medida socioeducativa de internação, o processo de formação e (re)socialização desenvolvidos em Unidade de Atendimento Socioeducativo de Unaí- MG.

Os objetivos específicos consistem em examinar as políticas educacionais que institucionalizaram e assistem a Unidade Socioeducativa; investigar as práticas educacionais desenvolvidas na Unidade/Escola e, como se articulam com as Políticas educacionais voltadas para a formação e (re)socialização dos adolescentes e compreender o perfil socioeducacional dos adolescentes, verificando a percepção deles 
em relação ao Sistema Socioeducativo, sobre o seu processo de formação e (re)socialização e os projetos de vida.

\subsection{O sistema socioeducativo de internação em Minas Gerais}

O Estado de Minas Gerais é uma das 27 unidades federativas do Brasil, localizado na região sudeste do país, com 853 municípios, constituindo-se como o segundo estado mais populoso. Segundo dados do Instituto Brasileiro de Geografia e Estatística - IBGE, o último censo registrou uma população de 19.597.330 habitantes, configurando em uma urbanização de 85\%. (BRASIL, 2010).

O IBGE divide o estado em 12 mesorregiões no intuito de favorecer a elaboração das políticas públicas e na alocação dos recursos econômicos e tributários. As 12 mesorregiões estabelecidas pelo IBGE para Minas Gerais são: Noroeste de Minas, Norte de Minas, Jequitinhonha, Vale do Mucuri, Triângulo Mineiro e Alto Paranaíba, Central Mineira, Metropolitana de Belo Horizonte, Vale do Rio Doce, Oeste de Minas, Sul e Sudoeste de Minas, Campos das Vertentes e Zona da Mata. (BRASIL, 2010).

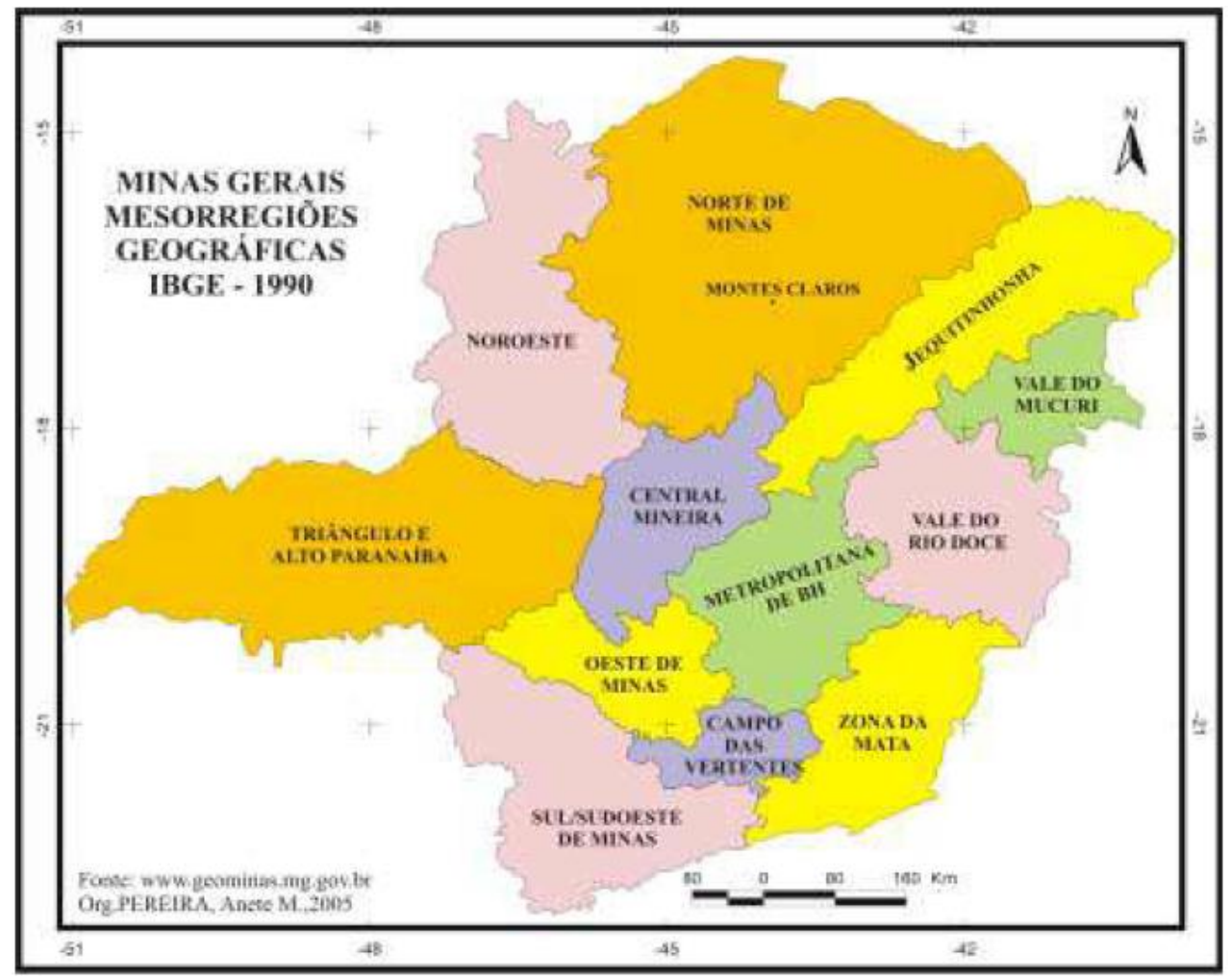

FIGURA 06 - Mapa de Minas Gerais - Mesorregiões Geográficas

Fonte: Pereira (2005). 
O processo de institucionalização da criança e do adolescente em Minas Gerais, não está divergente do fenômeno histórico vivido no restante do país, como já exposto anteriormente. Esses sujeitos viviam na sociedade quase no anonimato, não provocando nenhuma preocupação das autoridades, relevância social ou envolvimento deste grupo. A relevância principal do Estado de Minas Gerais durante o século XVII e XVIII se dava com a atividade de mineração, levando em conta que a mão de obra desses menores era de grande valia. Para Scarano (2009)

[...] Desde o século XVIII a preocupação era com o presente, não havendo nenhuma preocupação com as questões relacionadas a prevenção de enfermidades ou investimentos no futuro das crianças, já que no ano da euforia da mineração do ouro e do diamante buscava-se resolver o mais rapidamente o problema da mão-de-obra (SCARANO, 2009, p.114)

Segundo Oliveira (2010) em sua tese Perfil Socioeconômico dos atores de atos infracionais na cidade de Montes Claros - MG no final das décadas de 1970 e 1980 surge em Minas Gerais os Comissariados de Menores pelo Juiz de Menores, que fiscalizavam as irregularidades que estes envolviam. Em 1995 houve o fechamento das FEBEM's em Minas Gerais, começando um novo projeto chamado Casa-Lares com iniciativa do Estado e das Organizações não Governamentais e iniciativa privada. Atualmente Minas Gerais desenvolve projetos voltados para cuidados com a delinquência infanto-juvenil (re)socializando os adolescentes em conflito com a lei, em centros socioeducativos com vagas distribuídas em todas as regiões do estado.

No estado de Minas Gerais o órgão responsável pelo atendimento às medidas socioeducativas é a Secretaria de Estado de Defesa Social - SEDS. Em âmbito nacional, compete aos estados federados a formulação, instituição, coordenação e manutenção dos seus respectivos sistemas de atendimento socioeducativo, atentando sempre às diretrizes firmadas pela União (BRASIL, 2012).

A Lei $12.594 / 2012$ em seu artigo $4^{\circ}$ traz em seus dez incisos as demais competências que são de responsabilidade dos estados. Dentre os mais relevantes está a responsabilidade dos estados de criação, desenvolvimento e manutenção dos programas de atendimento destinados ao acompanhamento do cumprimento das medidas socioeducativas nos regimes de semiliberdade e de internação, bem como pela edição de normas complementares para a organização e funcionamento de seus respectivos sistemas de atendimento e aos sistemas dos municípios de cada estado (BRASIL, 2016). 
Em Minas Gerais a Subsecretaria de Atendimento Socioeducativo - SUASE, vinculada a Secretaria de Estado de Defesa Social - SEDS é responsável por elaborar, coordenar e executar a política de atendimento aos adolescentes autores de ato infracional no estado.

No contexto institucional, existem no estado de Minas Gerais $36^{29}$ (trinta e seis) unidades de atendimento socioeducativo, sendo que 24 (vinte e quatro) destas são centros socioeducativos, 11 (onze) casas de semiliberdade e 01 Centro Integrado de Atendimento ao Adolescente Autor de Ato Infracional (CIA-BH).

As Unidades que atendem as medidas de internação e internação provisória concentram-se em sua maioria na capital do estado. Belo Horizonte possui 09 destas unidades, sendo as 15 restantes distribuídas pelas cidades de Divinópolis, Governador Valadares, Ipatinga, Juiz de Fora, Montes Claros, Patos de Minas, Patrocínio, Pirapora, Ribeirão das Neves, Sete Lagoas, Teófilo Otoni, Uberaba, Uberlândia e Unaí.

As chamadas Casas de Semiliberdade também possuem um número maior na capital, com 07 unidades no total. As demais cidades do estado que recebem essas unidades são Governador Valadares e Muriaé com 01 unidade em cada e a cidade de Juiz de Fora com 02 duas unidades.

De acordo com a SEDS/MG o atual trabalho realizado com os adolescentes em conflito com a lei é desenvolvido por uma equipe especializada e multidisciplinar, proporcionando atividades culturais, esportivas, profissionalizantes, escolares e artísticas.

O estado de Minas Gerais oferta ao todo, 1.477 vagas, distribuídas pelas suas regiões, sendo que destas vagas, 1.240 são destinadas à internação e à internação provisória. Ao cumprimento de medida nas Casas de Semiliberdade estão destinadas 207 vagas.

O documento Levantamento Anual Sinase 2013, relatório publicado pela Secretaria de Direitos Humanos da Presidência da República no ano de 2018, revela dados importantes sobre a institucionalização de adolescentes em conflito com a lei. Os resultados deste levantamento indicaram que 21 unidades da federação e o Distrito Federal tiveram um aumento na restrição e privação de liberdade de adolescentes, incluindo neste dado o estado de Minas Gerais.

\footnotetext{
${ }^{29}$ Dados fornecidos pela Secretaria de Estado de Defesa Social - SEDS, atualizados em 29 de Novembro de 2016 às 17h10. Disponível em < http://www.seds.mg.gov.br/socioeducativo>, acesso em 30 de setembro de 2017.
} 
O relatório mostrou que no ano de 2013, 1068 adolescentes em conflito com a lei cumpriam a medida de internação no estado de Minas Gerais, 322 em unidade de internação provisória e 172 cumpriam a medida socioeducativa de semiliberdade. Destarte, isso mostra uma somatória de 1.562 adolescentes neste contexto, sendo o número total no país de 23.066.

Estes dados merecem especial atenção ao serem comparados com o primeiro levantamento feito no ano de 2008, em que apenas 634 adolescentes em conflito com a lei cumpriam a medida de internação no estado, 265 a medida de internação provisória e apenas 82 a medida de semiliberdade.

Conforme já exposto, o Sinase apresenta em sua proposta política a inclusão do adolescente em conflito com lei, correlacionando com outras políticas públicas e sociais - sistema educacional, de saúde, de assistência social e o sistema de Justiça e segurança pública. O estado de Minas Gerais assiste aos adolescentes em todos estes campos (BRASIL, 2015).

Tomando como recorte apenas o sistema educacional, esta política atua de forma estruturante nas instituições socioeducativas, não apenas pelo amparo e força legal que possui, mas pela sua atuação no processo de (re)socialização.

A Constituição Federal de 1988, que rompendo arcaicos paradigmas que se mantinham na sociedade brasileira e no intuito de democratizar as políticas educacionais, traz em seu artigo 205 que a

[...] educação é um direito de todos e dever do Estado e da família, será promovida e incentivada com a colaboração da sociedade, visando ao pleno desenvolvimento da pessoa, seu preparo para o exercício da cidadania e sua qualificação para o trabalho (BRASIL, 1988).

A Emenda Constitucional n $n^{\circ} 59$ da CF, trouxe em seu inciso I que a "educação básica é obrigatória e gratuita dos 4 aos 17 anos de idade, assegurada inclusive sua oferta gratuita para todos os que a ela não tiveram acesso na idade própria” (BRASIL, 1988).

A Lei de Diretrizes e Bases - LDB (Lei no 9394/96) define que:

Art. $1^{\circ}$ A educação abrange os processos formativos que se desenvolvem na vida familiar, na convivência humana, no trabalho, nas instituições de ensino e pesquisa, nos movimentos sociais e organizações da sociedade civil e nas manifestações culturais.

Art. $2^{\circ}$ A educação, dever da família e do Estado, inspirada nos princípios de liberdade e nos ideais de solidariedade humana, tem por 
finalidade o pleno desenvolvimento do educando, seu preparo para o exercício da cidadania e sua qualificação para o trabalho.

Art. $5^{\circ} \mathrm{O}$ acesso à educação básica obrigatória é direito público subjetivo, podendo qualquer cidadão, grupo de cidadãos, associação comunitária, organização sindical, entidade de classe ou outra legalmente constituída e, ainda, o Ministério Público, acionar o poder público para exigi-lo.

Destarte, na promulgação da Lei 12.594/12, especificamente em seu artigo 82, ficou estabelecido o prazo de um ano para que os órgãos responsáveis pelo sistema de educação pública garantissem a inserção dos adolescentes em cumprimento de medidas socioeducativas na rede pública de ensino, em qualquer fase do período letivo, contemplando as diversas faixas etárias e níveis de instrução. (BRASIL, 2016).

A SEDS/MG, com dados atualizados em novembro do ano de 2016 registrou que $91 \%$ dos adolescentes, cumprindo medida socioeducativa de internação em Minas Gerais, estão matriculados na escola. O número total de adolescentes, neste contexto e no mesmo ano, foi de 119.675 no Brasil, conforme dados divulgados pelo último Censo Escolar da Educação Básica / 2016.

\subsection{Os sujeitos e o local da pesquisa}

De forma sucinta, a legislação especial que regulamenta o Sistema Nacional de Atendimento Socioeducativo - SINASE, reporta-se do artigo 112, da Lei 8.069/1990 (Estatuto da Criança e do Adolescente - ECA) que descreve as possíveis medidas socioeducativas que podem ser determinadas a adolescentes atores de ato infracional e sujeitos desta pesquisa. Tais medidas são: advertência, obrigação de reparar o dano, prestação de serviços à comunidade, liberdade assistida, regime de semiliberdade e regime de internação (RAMIDOFF, 2012).

A medida socioeducativa de internação, única a ser analisada nesta pesquisa, pode ser definida "como a intervenção estatal de cunho protetivo-pedagógico mais rigorosa em relação as demais". Esta medida é sempre cumprida em unidade adequada estrutural e funcionalmente, visto que as atividades pedagógicas (educacionais, profissionalizantes, aprendizagens, esportivas, culturais etc.) são obrigatórias aos adolescentes (RAMIDOFF, 2012, P. 14).

Neste viés, registra-se aqui que uma das motivações pela escolha do tema se dá pela minha formação como professor graduado em geografia e atual experiência 
profissional como escrivão de polícia judiciária, lotado na Polícia Civil do estado de Minas Gerais há 04 anos. O contato quase que diário com adolescentes atores de ato infracional despertou em mim o desejo de aprofundar mais na realidade que estes sujeitos vivem. E, não apenas analisar o estado de restrição de liberdade, mas ir além. Compreender as estruturas familiares, os laços afetivos ao longo da adolescência, a representação da escola na vida deles, os projetos de vida, as motivações, as angustias, enfim, um projeto audacioso, mas cercado de muito respeito, sensibilidade e dignidade por estes adolescentes, tão marginalizados, vulneráveis e estigmatizados como mostra a história no Brasil.

A proximidade com estes adolescentes me fazia conhecer de perto a perversidade e a astúcia que muitos atos infracionais eram cometidos, mas paradoxalmente essa proximidade é superficial e técnica. Ao mesmo tempo não se pode ignorar o preconceito velado que a sociedade tem diante destes adolescentes. Sobre isso (1991b, p.13) ratifica que "quando se aborda um objeto tão pouco convencional para as ciências sociais no Brasil, como é o caso da criminalidade, é difícil não ser um investigador invadido por ideias profundas e sentimentos contraditórios".

Esse contexto exigiu, enquanto pesquisador, um necessário distanciamento em relação ao objeto de estudo (o que não me tornou indiferente), para não ser contaminado pela realidade vivida no meu local de trabalho ou pelas opiniões exploradas pela mídia e pelas reações que delas se desencadeiam em diferentes segmentos da sociedade.

Isto posto, é extremamente importante trazer a lume, ou pelo menos tentar, a percepção que esses adolescentes possuem quanto a sua formação e (re)socialização, quando são coercitivamente, por determinação judicial, inseridos em uma Unidade de Atendimento socioeducativo, para cumprir medida socioeducativa de internação.

A proposta desta pesquisa ao elucidar o entendimento sobre a (re)socialização não pretende trazer à tona as críticas e discussões que pairam sobre a eficácia e eficiência de suas políticas e práticas no ambiente da sociologia. $\mathrm{O}$ intuito sim é forjar o entendimento inserido no contexto que o termo é utilizado no sistema de ensino, partindo do pressuposto de Durkheim (1978) que o ser humano é um ser social e é constituído principalmente do processo educativo.

As políticas educativas de inclusão partem do princípio que o acesso ao ensino é para todos sem distinção de sexo, cor, condição social, física ou intelectual, origem ou religião (SANCHES \& TEODORO, 2006). Sendo assim, ampliam-se os sujeitos neste 
cenário, tendo como exemplos indivíduos em cumprimento de penas em cárceres, os adolescentes e jovens sujeitos a medidas socioeducativas de internação, entre outros, que tem a educação como uma das principais ferramentas no processo de inserção social.

Nota-se que o conceito de (re)socialização é complexo e vai muito além do que criar oportunidades através de políticas públicas. O cerne do entendimento deve partir do valor social que é atribuído a inclusão, para só depois compreender melhor a exclusão. Retomando a afirmação de Campos e Campos (2013, p. 189) "não é possível discutir a exclusão sem fazer referência ao valor social da inclusão". Pois o que de fato existe não é a exclusão, mas "formas precárias, instáveis e marginais de inclusão".

A educação em cárceres ou projetos e práticas pedagógicas destinadas a adolescentes atores de ato infracional é tema abrangente e desafiador, pois busca compreender a articulação e o desenvolvimento das diretrizes que levam a inclusão social, ou seja, a (re)socialização. Souza (2009, p.26) citando Durkheim (1987, p. 42) atribuindo à educação o papel socializador, discorre que

[...] A educação é a ação exercida pelas gerações adultas, sobre as gerações que não se encontrem ainda preparadas para a vida social; tem por objetivo suscitar e desenvolver na criança, certo número de estados físicos, intelectuais e morais, reclamados pela sociedade política, no seu conjunto, e pelo meio especial, a que a criança particularmente, se define.

A escolha do local partiu da premissa de que ao desenvolver um estudo a preocupação central é a compreensão de uma instância singular da realidade que é multidimensional (LUDKE; ANDRE, 1986). Assim, foi escolhida uma escola que funciona dentro de uma Unidade de Atendimento Socioeducativo na cidade de Unaí, localizada na região noroeste do estado de Minas Gerais, a 601,3 km de distância da capital Belo Horizonte. O fator geográfico também foi determinante na escolha dessa unidade, permitindo um deslocamento mais acessível no momento da aplicação dos instrumentos de coleta de dados. 


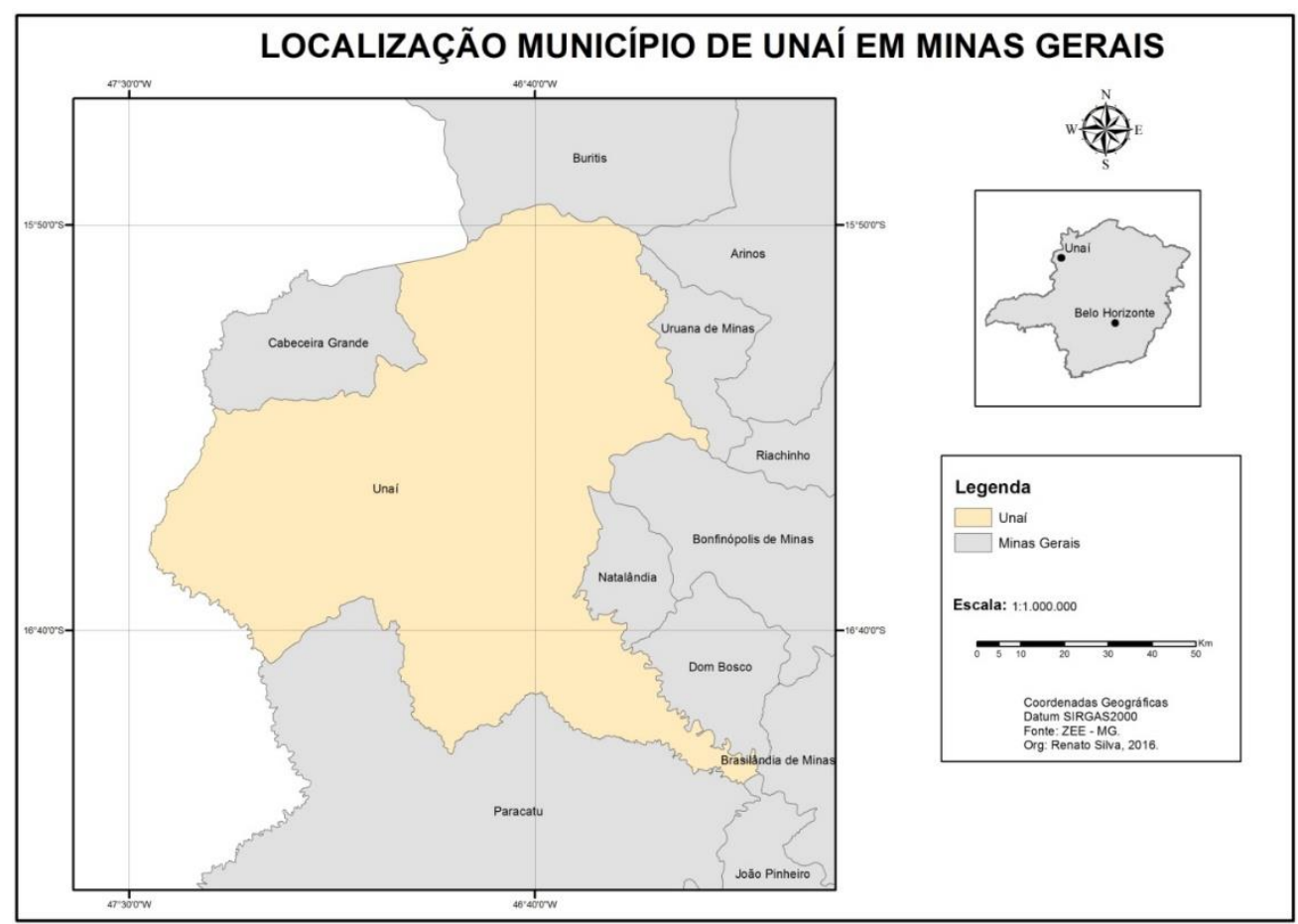

FIGURA 07 - Localização do Município de Unaí - MG

Fonte: (SILVA, 2016)

A escola atende, única e exclusivamente, aos adolescentes que cumprem a medida socioeducativa de internação e que são enviados ao local por determinação judicial. A Lei 12.594, de 18 de janeiro de 2012 dispõe da organização, estruturação e funcionamento, bem como regulamenta as atividades, diretrizes e práticas na execução das medidas socioeducativas, determinadas judicialmente a adolescentes em conflito com a lei (RAMIDOFF, 2012).

\subsection{O Centro de Atendimento Socioeducativo de Unaí - CSEUN}

O Centro Socioeducativo de Unaí - MG (CSEUN) está localizado em uma área periférica e distante da área central, na rua Amaro Rodrigues da Silva, 452, no bairro Santa Clara. Sua inauguração foi no dia 08 de maio do ano de 2013, construída exclusivamente para atender adolescentes do sexo masculino, encaminhados para cumprirem medida socioeducativa de internação. A capacitação máxima do local é para 90 adolescentes.

A unidade, no dia da visita ao local, possuía 01 diretor geral, 01 diretor de segurança, 01 diretor de atendimento, 03 supervisores de segurança, 03 pedagogos, 01 
psicólogo, 02 jurídicos, 02 assistentes sociais, 02 auxiliares educacionais, 01 enfermeira e 04 técnicos de enfermagem. A escola que funciona dentro da unidade, oferta desde a sexta série do ensino fundamental até o terceiro ano do Ensino Médio. Um total de 18 professores atuam no CSEU e 11 deles trabalham também no Ensino Médio. O número de agentes socioeducativos, atualizados em primeiro de setembro de 2017 era de 115.

No que tange a estrutura física, a unidade, no dia da visita ao local, possuía uma Área Interna Bloco Administrativo -local de administração da unidade, onde não há atendimento aos adolescentes. Ali há 09 salas que abrigam a diretoria geral, de segurança e de atendimento, equipe administrativa e técnica. A Área Interna Bloco de atendimento é um espaço destinado ao atendimento dos adolescentes, principalmente na área de saúde e possui 01 enfermaria, 01 farmácia, 01 Central de Material de Esterilização - área suja, 01 área limpa, 01 depósito de medicamentos, 01 sala para atendimento odontológico, 01 sala para atendimento médico com banheiro, 01 sala para atendimento psicológico, 01 sala da supervisão de segurança com banheiro, 01 sala de atendimento geral, 03 alojamentos individuais com banheiros, sendo 01 para pessoas com deficiência, 01 biblioteca adaptada em um alojamento, 01 copa e 02 banheiros para pessoas com deficiência. Há ainda 01 almoxarifado, 01 lavanderia e um refeitório com cozinha e dois banheiros.

O local de acomodação dos adolescentes no CSEU é dividido em dois núcleos, denominados como Núcleo I e Núcleo II, com quatro blocos neste e três blocos nesse. O Núcleo I Bloco A possui 05 alojamentos com 03 camas e um banheiro, 01 sala de TV e 01 sala dos agentes com banheiro; Núcleo I Bloco B possui 06 alojamentos com 03 camas e um banheiro, 01 alojamento com 02 camas para pessoas com deficiência, 01 sala de TV e 01 sala dos agentes com banheiro e no Núcleo I Bloco C há 05 alojamentos individuais com banheiros e 01 sala dos agentes com banheiro. $\mathrm{O}$ espaço interno do núcleo I conta ainda com 01 quadra esportiva com 04 banheiros, sendo um para pessoas com deficiência, 02 salas de atendimento, 04 salas de oficina/escola, com 02 banheiros coletivos, 01 sala oficina/escola com banheiro, 01 pátio interno, 01 horta e 01 guarita na entrada do núcleo.

No Núcleo II Bloco A há 07 alojamentos com 03 camas e um banheiro, 01 sala de TV e 01 sala dos agentes com banheiro; o Núcleo II Bloco B contém 06 alojamentos com 03 camas e um banheiro, 01 alojamento com 02 camas para pessoas com deficiência, 01 sala de TV e 01 sala dos agentes com banheiro; o Núcleo II Bloco C 
possui 05 alojamentos individuais com banheiros e 01 sala dos agentes com banheiro neste bloco funciona o atendimento aos adolescentes em cumprimento da medida socioeducativa de internação provisória e o Núcleo II Bloco D, com 05 alojamentos individuais com 02 banheiros coletivos. O espaço interno do núcleo II conta ainda com 01 quadra esportiva com 04 banheiros, sendo dois para pessoas com deficiência; 02 salas de atendimento; 01 escola com 05 salas, 01 biblioteca, 01 banheiro coletivo e aos fundos funciona a supervisão da escola, com 02 salas dos professores, 01 depósito, 01 copa e 01 banheiro; Bloco de oficina/escola, com 03 salas, 01 banheiro e 01 sala de informática; 01 pátio interno, 01 horta e 01 guarita na entrada do núcleo com dois banheiros e 01 copa.

A Unidade possui 03 bibliotecas, sendo 01 em casa um dos núcleos, sob cuidados da escola e 01 no Bloco de Atendimento, sob os cuidados da equipe pedagógica. Há um laboratório de informática sem internet, instalada no Núcleo II, que é utilizada pelos professores para fins escolares com os adolescentes.

\subsection{Os instrumentos de coleta de dados}

Foram utilizados como instrumentos de coleta de dados a observação, entrevista semiestruturada e questionário para aferir os resultados pretendidos através dos objetivos apresentados. Esta intervenção direta aconteceu com os professores que atuam na escola da Unidade e com quatorze adolescentes que cumprem a medida socioeducativa de internação, regularmente matriculados no Ensino Médio.

Os instrumentos são importantes na pesquisa qualitativa pela interação que eles proporcionam com os sujeitos, tornando-se um recurso que permite o outro expressarse, produzindo assim informação (dados). Para González Rey (2015) os instrumentos,

[...] sempre que seja compreendidos como formas diferenciadas $\mathrm{d}$ expressão das pessoas e que adquirem sentido subjetivo no contexto social da pesquisa, representam uma via legítima para estimular a reflexão e a construção do sujeito a partir de perspectivas diversas que podem facilitar uma informação mais complexa e comprometida com o que estudamos (GONZÁLEZ REY, 2015, p. 42).

Ainda sobre os instrumentos González Rey (2015) acrescenta que: o instrumento representa apenas o meio pela qual vamos provocar a expressão do outro sujeito; todo instrumento representará apenas uma fonte de informação, separada de qualquer sistema de categorias preestabelecidas para significá-la; os instrumentos formam um sistema do 
qual uns se relacionam com os outros, dando lugar a um sistema único de informações; os instrumentos apoiam em expressões simbólicas diferenciadas das pessoas, entre as quais terão um maior valor aquelas que constituem as vias preferenciais de expressão para cada sujeito concreto; os instrumentos representam meios que devem envolver as pessoas emocionalmente, o que facilitará a expressão de sentidos subjetivos; e os instrumentos não seguem regras padronizadas de construção.

A observação, como instrumento válido e fidedigno da investigação científica precisa ser controlada e sistemática, conforme afirma Ludke e Andre (1986). Ainda para estes autores, "implica na existência de um planejamento cuidadoso do trabalho e uma preparação rigorosa do observador" (LUDKE; ANDRE, 1986, p. 25).

A observação induz imediatamente à ideia de uma investigação que segue caminhos menos normatizados e tem protocolos mais flexíveis. O planejamento da observação direta foi determinado com antecedência, propondo observar os alunos durante as atividades socioeducativas e a percepção destes quanto à formação que recebiam e a perspectiva destes sujeitos quanto à (re)socialização proposta na Unidade.

A descrição da observação, que consiste no registro detalhado da experiência no local, se deu com base na orientação dos autores Bodgan e Biklen (1982) sendo, a descrição dos sujeitos; a reconstrução dos diálogos; a descrição da unidade; a descrição dos principais eventos; a descrição das atividades observadas e do próprio comportamento do observador.

A visita à Unidade de Atendimento Socioeducativo em Unaí - MG ocorreu no dia 26 de junho de 2017, no período matutino e vespertino. A supervisão da escola reuniu todos os professores em uma das quadras de esporte para que fosse apresentada a eles a pesquisa, seus objetivos e o convite para participarem dela mediante resposta ao Questionário Docente. A unidade conta com um total de 18 professores, distribuídos no ensino fundamental e médio, sendo que destes, 11 trabalham com os alunos do ensino médio. Apenas seis professoras e um professor, dos 11 que trabalham no Ensino Médio, aceitaram participar da pesquisa respondendo ao questionário.

Na referida data o Centro Socioeducativo de Unaí - CSEUN contava com 102 adolescentes internados, cumprindo medida socioeducativa de internação. A estrutura física do local foi construída com capacidade para 90 adolescentes. A distribuição física dos adolescentes na Unidade acontece em dois núcleos, identificados como Núcleo 01 (Blocos A, B e C) e Núcleo 02 (Bloco A, B, C e D). Essa divisão não permite o contato 
entres os internos de núcleos diferentes. De acordo com a direção pedagógica, esta divisão não segue necessariamente um critério, mas aproveitam a sua existência para colocarem separados adolescentes que por ventura tenha algum tipo de rivalidade ou o que os adolescentes chamam de "guerra" fora da unidade.

O critério utilizado para selecionar os adolescentes que participariam diretamente da pesquisa foi selecionar alunos do ensino médio. Os adolescentes matriculados na escola do Núcleo 01 foram selecionados, por ser um quantitativo menor e suficiente para se chegar aos objetivos. Este núcleo, na data referência, contava com uma turma do primeiro ano, uma turma do segundo ano e uma turma do terceiro ano do ensino médio, com dez, quatro e dois alunos respectivamente. Na data da visita à Unidade, dois alunos haviam conseguido um benefício judicial e teriam saído temporariamente para visitar seus familiares, participando assim quatorze adolescentes.

Trabalhar com o número menor de adolescentes facilitou também a dinâmica de organização e mobilidade dentro da Unidade, pois cada deslocamento exige um esquema de segurança rigoroso entre os agentes socioeducativos e os professores. Há um cronograma de segurança que deve ser seguido a todo o momento.

Os adolescentes, das três séries distintas, foram reunidos em uma única sala, na presença de alguns agentes socioeducativos que a todo tempo ficaram presentes e foi apresentada a eles a proposta da pesquisa, os objetivos, a importância da participação de cada um e o convite para responderem ao Questionário aos Alunos e entrevista que aconteceria em outro momento. Nenhum dos adolescentes se opôs e todos os cuidados foram tomados para que não se sentissem coagidos e pressionados para participarem. Mas em alguns momentos surgiram algumas indagações como: "isso vai interferir na minha pena?”; “isso é coisa do Juiz?”; “se eu responder ajuda a diminuir o meu tempo aqui?"”.

No período da manhã foi realizada a aplicação de questionário, elaborado com perguntas fechadas e abertas, para quatorze adolescentes, ao mesmo tempo reunidos em uma única sala. Os adolescentes respondiam as perguntas assim que elas eram lidas para todos ao mesmo tempo. Esta estratégia na aplicação do questionário foi necessária para que todos começassem e terminassem juntos, não comprometendo assim as normas de segurança - extremamente rígidas, e não interferisse também na escala de atividades já programadas para aquele dia. 
Foram levantados dados quantitativos e qualitativos que possibilitaram vislumbrar e traçar o perfil do adolescente privado de liberdade na Unidade de Unaí. Esse tema não deve ser tratado de maneira simplificada e lançou por terra qualquer tentativa de evocar falsas relações de causa e consequência, como pobreza, cor da pele, estrutura familiar, baixa escolaridade ou demais associações ideológicas. O objeto desta pesquisa é bastante complexo e exige-se que ao ser analisado tenha uma sensibilidade e se esvazie de qualquer (pré) concepção.

Para que fosse possível compreender as práticas educacionais desenvolvidas na Unidade foi aplicado também um questionário aos professores. O objetivo deste instrumento é permitir a construção dos sentidos subjetivos e dos processos simbólicos distintos que caracterizam as configurações subjetivas de cada docente (GONZALEZ REY,2005).

O questionário aplicado aos professores foi estruturado em categorias que possibilitaram fazer tal análise, sendo elaborado da seguinte maneira: dados gerais; funções que realiza na escola; condições de trabalho na escola; trabalho didático que desenvolve na escola/unidade; e processo de ensino aprendizagem e seus resultados.

Os dados gerais permitiram compreender este profissional, quanto ao gênero, idade, formação e principalmente a experiência em trabalhar com adolescentes atores de ato infracional. As funções que realiza na escola aferirão a(s) disciplina(s) que ministra, o número de aulas/semanal e números de turmas.

A compreensão das condições de trabalho que os professores estão sujeitos está intrinsecamente ligada à percepção, sob a ótica dos adolescentes, de sua formação. Sendo assim, no questionário aos professores, foram inquiridos sobre os itens disponíveis na unidade, como biblioteca, laboratórios, salas de multimeios, entre outros. E algumas singularidades foram questionadas, como segurança e a presença de agentes socioeducativos acompanhando os adolescentes durante as aulas.

Para González Rey (2015, p. 55) o questionário

[...] representa um sistema de indutores pensados em seu conjunto para facilitar a expressão da maior quantidade de informações possível por parte do sujeito, que é obtida por meio de perguntas que possam ter um caráter complementar na expressão da informação sobre o estudado.

O questionário é o instrumento mais utilizado em pesquisas qualitativas, entre as ciências antropossociais. Está associado à análise das representações e das crenças 
conscientes dos sujeitos pesquisados que vão formulando e construindo as respostas, mediadas por intencionalidades (GONZÁLEZ REY, 2015).

Destarte, ao aplicar em um primeiro momento o questionário com os adolescentes pretendeu-se diagnosticar informações básicas e os perfis sociais, econômicos e principalmente o perfil educacional. É importante compreender o seu contexto familiar, seu lugar de origem, seu contato com atividades de lazer, esporte, cultura e o ingresso as práticas infracionais. O perfil educacional proporcionou compreender a trajetória escolar do adolescente.

Após aplicação do questionário com os adolescentes e, de posse dos dados essenciais, foi aplicada entrevista semiestruturada. Esta é fundamental no desenvolvimento da investigação pela interação social que possibilita, buscando a informação face a face com o entrevistado, em uma conversa orientada para o objetivo geral (MANZINI, 2003).

Como embasamento teórico sobre o conceito de entrevista, aplica-se aqui o entendimento de Ludke e Andre (1986, p.33) que afirmam ser a entrevista uma das principais técnicas de trabalho em que a relação que se cria é de interação com uma "atmosfera de influência recíproca entre quem pergunta e quem responde". A entrevista possui vantagem sobre os demais instrumentos, pois permite a captação instantânea e corrente da informação e sobre os mais diversos tópicos, principalmente a semiestruturada, que liberdade no seu percurso.

O roteiro da entrevista foi elaborado com atenção ao que foi proposto no objetivo geral da investigação. A entrevista possibilitou analisar com maior precisão, sob a percepção de adolescentes, o processo de formação e (re)socialização desenvolvidos na unidade.

Seguiu uma sequência de indagações que permitiu compreender desde o ingresso do adolescente na (s) prática (s) de ato (s) infracional (ais) até sua chegada na unidade, levando em consideração a adequação da linguagem e a forma das perguntas (MANZINI, 2003). É importante ressaltar que, conforme já esclarecido, por questões judiciais nas quais estes adolescentes são assistidos há certas restrições quanto às informações que podem prestar.

Dentro das possibilidades legais, o objetivo da entrevista foi compreender a percepção de cada adolescente quanto à formação que estão recebendo, inquirindo sobre avaliação do trabalho dos professores, a estrutura física da unidade, como se sentem ao 
frequentar as aulas, se os temas: meio ambiente, ética, sexualidade, cidadania, pluralidade cultural são discutidos em sala de aula pelos professores, os projetos de vida ao deixarem a unidade, entre várias outras questões.

Após a coleta dos dados, através dos instrumentos já expostos, a pesquisa seguiu para a fase de análise destes, através da organização sistemática de transcrições. O objetivo foi aumentar a compreensão dos dados obtidos e apresentar o relatório destes resultados (BOGDAN; BIKLEN, 1994).

O projeto de pesquisa foi submetido ao Comitê de Ética da Subsecretaria de Atendimento às Medidas Socioeducativas, por meio da Diretoria de Gestão da Informação e Pesquisa - DIP e da Diretoria de Formação Educacional e Profissional, todas ligadas a Secretaria de Estado de Defesa Social do Estado de Minas Gerais. Esses órgãos são os reguladores da Unidade de Atendimento Socioeducativo da cidade de Unaí - MG. O pedido foi protocolado sob o número 015.2016, tendo sido o parecer favorável e concedida autorização para a realização da pesquisa.

No mesmo trâmite, o projeto de pesquisa foi submetido ao Comitê de Ética em Pesquisa/CEP - UFG, juntamente com os documentos necessários, conforme reza as Resoluções CNS 466/2012 e 510/2016. Os documentos submetidos para analise foram: Termo de Responsabilidade do Pesquisador; Termo de Anuência do Diretor Geral da Unidade; Parecer do Comitê de Ética da Subsecretaria de Atendimento às Medidas Socioeducativas, por meio da Diretoria de Gestão da Informação e Pesquisa - DIP; Termo de Compromisso de Retorno dos Resultados; Termo de Consentimento Livre e esclarecido e Despacho com aquiescência do MM. Juiz de Direito titular da Vara Criminal, Infância e Juventude e Execução de Medidas Socioeducativas, no foro da Comarca de Unaí - MG, em 27 de março de 2017. Todos os documentos apresentados foram analisados, dado parecer aprovado, sob o protocolo 2.013.316, em acordo com os princípios éticos vigentes. 


\section{CAPÍTULO 05}

\section{PRÁTICAS E POLÍTICAS EDUCACIONAIS NO CENTRO SOCIOEDUCATIVO DE UNAÍ - CSEUN}

A proposta deste capítulo é apresentar um panorama geral sobre a aplicação da medida socioeducativa de internação na cidade de Unaí - MG, a fim de conhecer melhor

o perfil social, econômico e educacional dos adolescentes, os processos de execução da medida em tramitação, o trabalho dos professores e as condições de atendimento aos adolescentes, em conflito com a lei, nas estruturas as quais estão inseridos.

Considerando-se a conjugação dos resultados, é importante delinear que algumas informações foram validadas empiricamente por meio da pesquisa realizada no referido local. Buscou-se conhecer a realidade da unidade, através de aplicação de questionário aos professores e aplicação de questionário a um recorte de 14 adolescentes, que no período cumpriam a medida socioeducativa de internação e estavam regularmente matriculados no ensino médio. Com estes sujeitos ainda foi feita uma entrevista individual que permitiu aferir com maior propriedade a percepção que eles têm em relação ao sistema, a educação recebida e exporem seus projetos de vida.

\subsection{Como os professores analisam as práticas educacionais na escola do Centro de Atendimento Socioeducativo de Unaí-CSEUN}

Apesar do objeto central desta pesquisa ser a análise da percepção dos adolescentes em conflito com a lei, em cumprimento de medida socioeducativa de internação, quanto a formação e a proposta de (re)socialização na qual estão sujeitos na Unidade Socioeducativa de Unaí - MG, é imprescindível que se conheça também um pouco do trabalho dos professores que atuam diretamente com esses adolescentes e as práticas educacionais que eles mesmos desenvolvem.

Para isso serão apresentados aqui alguns dados importantes que caracterizam estes profissionais, como a formação, a função que realizam na escola da Unidade, as condições de trabalho e o posicionamento destes diante da singularidade que estão inseridos. O papel dos professores é de extrema importância no processo de formação e também na (re)socialização porque lidam diretamente com os adolescentes e vivenciam 
muito próximo a realidade, os anseios, os conflitos, as dificuldades e os projetos de vida de cada um.

Outro aspecto importante e desafiador no trabalho dos professores que atuam em unidades de internação é não descaracterizar os objetivos da própria educação, que nas palavras de Onofre (2011, p. 110) devem almejar "a formação de pessoas, a ampliação de sua leitura de mundo, o despertar da criatividade, a participação na construção do conhecimento e a superação de suas condições atuais". É desafiador porque cabe a estes docentes criarem possibilidades de trabalharem de forma criativa e inovadora em um local com inúmeras restrições e limitações políticas, administrativas e de segurança.

A escola talvez seja o eixo principal em todo o processo de atuação com os adolescentes em liberdade restrita, pois tem como missão a socialização e humanização dos sujeitos, com o anseio maior de contribuir para que esses aprendam a aprender e desenvolvam uma postura construtiva, autônoma e participativa. (VERDUM, 2013).

No que tange as práticas educacionais, Verdum (2013), ao se inspirar em Freire (1986), parte da concepção de que elas adjetivam do termo dialógica em que o conhecimento é construído através de um processo realizado tanto pelos professores quanto pelos alunos, caminhando pela direção de uma leitura crítica da realidade.

Também pode ser pensada como expressa Fernandes (2011, p. 59)

[...] Prática intencional de ensino e aprendizagem não reduzida à questão didática ou ás metodológicas de estudar e de aprender, mas articulada à educação como prática social e ao conhecimento como produção histórica e social, datada e situada, numa relação dialética entre prática-teoria, conteúdo-forma e perspectivas interdisciplinares.

Isto posto, não há uma receita pronta e acabada sobre como seria uma aula ideal ou quais seriam as principais características de uma boa prática educacional, especificamente para os sujeitos desta pesquisa. É possível sim apontar elementos que deveriam estar presentes nessas práticas, os quais devem partir do comprometimento ético de cada docente que, consequentemente, produzirá transformações sociais, com princípios de respeito, justiça, solidariedade e cidadania (VERDUM, 2013). Os docentes e todos os operadores do sistema socioeducativo devem possuir valores que estejam de acordo com os ideais de (re)socialização e motivação para este projeto.

Um dos possíveis elementos que poderia ser apontado aqui é a preservação dos direitos desses adolescentes, garantidos pelo ECA e pelo regramento do Sistema Nacional de Atendimento Socioeducativo. Zelar pelo tratamento digno, a 
individualidade e o respeito a situação peculiar de pessoa em desenvolvimento. E cuidar da manutenção dos vínculos dos adolescentes com seus familiares e comunidade.

A visita a Unidade de Atendimento Socioeducativo em Unaí - MG ocorreu no dia 26 de junho do ano de 2017, no período matutino e vespertino. A supervisão da escola reuniu todos os professores em uma das quadras de esporte para que fosse apresentado a eles a proposta da pesquisa e o convite para participarem dela mediante resposta ao questionário. Como o recorte da pesquisa se limitou apenas aos alunos do ensino médio, seis professoras e um professor se dispuseram a colaborar e responder ao questionário. Os professores que participaram não terão os seus nomes revelados neste texto e serão identificados quando necessário, em uma homenagem a personalidades laureadas com a premiação do Nobel da Paz, pelos nomes: Wided Bouchamaoui, Malala Yousafzai, Ellen Johnson-Sirleaf, Leymah Gbowee, Tawakel Karman, Wangari Muta Maathai e o único professor Juan Manuel Santos.

Wided Bouchamaoui, ministra as disciplinas de química e trabalha com um projeto de cidadania, graduada, não possui especialização, possui quatro anos de docência e não é a sua primeira experiência com adolescentes em conflito com a lei. Malala Yousafzai, ministra as disciplinas de história e filosofia, graduada, não possui especialização, possui quatro anos de trabalho na educação. Ellen Johnson-Sirleaf, ministra a disciplina de língua portuguesa, graduada, não possui especialização, cinco anos de experiência no ensino e é sua primeira experiência com adolescentes em conflito com a lei. Leymah Gbowee, ministra as disciplinas de língua inglesa, geografia e sociologia, pós-graduada, dois anos de trabalho na educação e sua primeira experiência com adolescentes em conflito com a lei. Tawakel Karm, professora de matemática, graduada, não possui especialização com três anos de trabalho na docência e não responde que é a primeira vez na unidade. Wangari Muta Maathai, ministra a disciplina de matemática, apenas graduada, com quatro anos de experiência na docência sendo que não é a primeira vez que trabalha com adolescentes em conflito com a lei. Juan Manuel Santos, professor de física e oficina de teatro, ainda não concluiu sua graduação, possui um ano e dois meses de experiência na docência e é a primeira vez que trabalha com adolescentes em conflito com a lei.

Todos os professores são vinculados a Secretaria Estadual de Educação do Estado de Minas Gerais - SEE/MG, porém nenhum deles possui vínculo efetivo, sendo 
apenas designados (contratação temporária), com cinco professores com renda mensal de 01 a 02 salários mínimos e dois com renda mensal de 03 a 04 salários mínimos.

Mesmo compreendendo que a escola da Unidade socioeducativa proporciona para os adolescentes uma educação formal, com a mesma grade curricular das demais escolas da rede pública estadual, é importante destacar, na minha visão, que os professores tenham um olhar ainda mais sensível e compreendam o universo que estes adolescentes estão sujeitos. Universo este que vai muito além de uma aula ministrada em 40 ou 50 minutos. Universo este que engloba todo um projeto desafiador e ousado de reinserir na sociedade o adolescente em conflito com a lei e resgatar sua dignidade e cidadania.

Pensando nisso, foi questionado aos professores se possuem conhecimento sobre a Lei 8.069/90 - Estatuto da Criança e do Adolescente, sendo que seis deles alegaram conhecer e já ter lido e apenas um alegou conhecer, porém nunca leu. Questionados ainda se tinham conhecimento sobre a Lei 12.594/12, que cuida da criação, manutenção e operacionalização do Sistema Nacional de Atendimento Socioeducativo, a maioria respondeu que conhece e já leu, um deles respondeu que conhece e nunca leu e um destes profissionais respondeu que desconhece a referida lei.

Questionados se conhecem o Portal da Escola Nacional de Socioeducação ENS, que tem como objetivo proporcionar formação continuada para os diferentes profissionais que atuam direta ou indiretamente no sistema, inclusive professores, seis disseram desconhecer o portal e consequentemente nunca realizaram algum curso de capacitação ou formação disponível no ambiente virtual de aprendizagem. Apenas a professora Wided Bouchamaoui respondeu conhecer o portal, mas sem realizar nenhum curso de capacitação.

No que tange as condições de trabalho na escola, foi questionado as professoras e ao professor como avaliam a estrutura física e os recursos disponibilizados nas salas de aula e unidade, sendo que quatro avaliam como bom e três como regular. Foram indagados sobre a existência de alguns itens, e os indicados foram: biblioteca, laboratório de informática, sala de artes e quadra de esporte e lazer.

Sobre a presença dos agentes socioeducativos, apoio técnico da Secretaria Estadual de Defesa Social - SEDS, no momento em que as aulas são ministradas, três professores responderam que estão sempre presentes, dois responderam quase sempre, um respondeu eventualmente e um respondeu quase nunca. Quanto a avaliação da 
presença dos agentes socioeducativos na sala de aula, dois acreditam ser excelente, dois ótimo e três professores avaliam como bom. Não foi mencionado quantos agentes acompanham a ministração das aulas.

Questionados se a presença dos agentes socioeducativos pode intimidar ou comprometer o desempenho dos alunos, seis responderam que não. Para a professora Ellen Johnson-Sirleaf, nas palavras dela "a presença do agente ajuda na disciplina, por isso as aulas se tornam mais eficazes". Para a professora Wangari Muta Maathai "a presença dos agentes ajuda, para segurança e respeito com a classe docente". Apenas o professor Juan Manuel Santos acredita que as aulas ficam comprometidas com a presença de agentes e sobre isso disse: "acho que compromete sim, em algumas aulas onde o agente não está presente, vejo que os alunos são mais humildes e verdadeiros; na presença do agente é como se eles virassem 'machões'; deve ser para fazer 'frente' com os colegas".

Um apontamento de expressiva importância na caracterização dos docentes, diz respeito ao fato de acreditarem ou não se as condições de trabalho da escola - estrutura física, corpo docente, recurso e matérias didáticos, assistem integralmente aos alunos em cumprimento de medida socioeducativa de internação, o que apresentou opiniões divergentes. Quatro profissionais acreditam que sim e três responderam que não. Com exceção de um professor, todos acrescentaram, destacando algumas respostas: "não, falta um laboratório de química, internet e não podemos utilizar alguns materiais por medidas de segurança" (Wided Bouchamaoui); "não, poderia haver uma sala com materiais necessários para assistir filmes, ensaiar peças, com materiais destinados as aulas diferenciadas" (Ellen Johnson-Sirleaf); “sim, proporciona os meios necessários aos adolescentes que se comprometem com os estudos" (Leymah Gbowee); "sim, uma sala por turma, um professor por disciplina, quantidade reduzida de alunos por turmas, livros, biblioteca, computadores, material de artes, lanche diariamente, acho mais que excelente" (Juan Manuel Santos).

Os professores responderam também quanto ao fato dos alunos serem adolescentes atores de ato infracional e como se sentiam trabalhando com esses sujeitos: seis docentes responderam que este fato não interfere nas aulas e apenas uma professora respondeu que fica intimidada durante as aulas. 


\subsection{Os professores no processo de formação e (re)socialização dos alunos}

Para que a política de atendimento a adolescentes que cumprem as medidas socioeducativa de internação, estabelecidas pelo Estatuto da Criança e do Adolescente (ECA Lei $n^{\circ}$ 8.069/1990) e reguladas pelo SINASE (Resolução ${ }^{\circ}$ 119/2006 e a Lei Federal $\mathrm{n}^{\circ}$ 12.594/2012) se torne eficiente e eficaz é necessário que o modelo de educação respeite integralmente os direitos destes sujeitos, o que demanda investimentos na formação dos profissionais do sistema socioeducativo.

Inclusive, uma das propostas da ENS é garantir que os programas de formação, incluindo o trabalho dos professores, consigam articular a teoria e a prática, à construção coletiva do conhecimento, a troca de experiências, a valorização dos saberes profissionais, a reflexão crítica, a sistematização e o registro das práticas institucionais, bem como a construção de fundamentos teóricos e metodológicos comuns. A seguir será apresentada a análise feita pelos professores na Unidade Socioeducativa de Unaí MG quanto às práticas educacionais destinadas a formação e (re)socialização dos adolescentes.

Sobre o trabalho didático que desenvolvem na escola, os professores foram unânimes em dizer que preparam a disciplina do ponto de vista didático e que realizam o planejamento das aulas semanalmente. Questionados se os planos de disciplinas e aulas acontecem de forma individual, coletiva ou ambos, três professores responderam que planejam individualmente e quatro responderam que planejam tanto individualmente quanto de forma coletiva.

A maioria dos professores alegou não receber orientação e/ou formação especifica para trabalhar com adolescentes atores de ato infracional. Apenas dois professores disseram que sim e fizeram as seguintes considerações, ao serem orientados a citarem as orientações e/ou formações mais relevantes: "sim, metodológica e diretrizes curriculares do socioeducativo, proposta pedagógica" (Wided Bouchamaoui); “sim, videoconferência/reunião com orientações sobre o sistema e seu funcionamento" (Ellen Johnson-Sirleaf).

Em média, os professores se reúnem no mínimo três vezes por ano para realizarem conselhos de classe. Além disso, cinco professores responderam que se reúnem semanalmente para reuniões de caráter didático, que denominaram de Módulo Pedagógico Semanal. 
Ao serem indagados sobre como foi desenvolvido o Projeto Político Pedagógico não foram unânimes. Dois professores responderam não saber, três responderam que foi elaborado pelo diretor e por uma equipe de professores e dois responderam que pela aplicação de modelo encaminhado pela Secretaria Estadual de Educação.

Sobre o processo de ensino-aprendizagem e seus resultados, as seis professoras e o professor foram questionados se práticas interdisciplinares são desenvolvidas em suas aulas e se consideram satisfatórios os trabalhos interdisciplinares. Os dados mostraram que três professores sempre usam práticas interdisciplinares em suas aulas, dois quase sempre e dois usam eventualmente. No entanto, todos foram unânimes em responder que acreditam ser satisfatório o trabalho interdisciplinar.

Os temas cidadania, sexualidade, meio ambiente, ética, pluralidade cultural e saúde, classificados como transversais, foram citados pelo menos uma vez pelos professores, como assuntos trabalhados em suas aulas ou na escola. De acordo com os Parâmetros Curriculares Nacionais - $\mathrm{PCN}^{30}$ 's (BRASIL, 1997) o compromisso com a construção da cidadania pede necessariamente uma pratica educacional voltada para a compressão da realidade social, além dos direitos e responsabilidades em relação à vida pessoal, coletiva e ambiental. A proposta dos temas transversais é que sejam incorporados nas áreas já existentes e no trabalho educativo da escola. Correspondem a questões importantes, urgentes e presentes sob várias formas, na vida cotidiana e devem ser abordados com cuidado e atenção ainda maior dentro do contexto da realidade vivida por adolescentes em conflito com a lei.

Umas das perguntas centrais feita aos professores foi quais as práticas educacionais utilizam para contribuir com o processo de formação e (re)socialização dos adolescentes atores de ato infracional. Com exceção de um professor, todos fizeram apontamentos: "diálogos, mini palestras, seminários e vídeos motivacionais” (Wided Bouchamaoui); "englobar temas sociais, de caráter ligado aos direitos e deveres do cidadão, postura, comportamento e autoestima dentro dos temas abordados na disciplina [...]”; (Ellen Johnson-Sirleaf); “conversas de motivação ressaltando os valores, filmes para reflexão do aluno (pedagógico), dinâmica em grupos, atendimento com psicólogos” (Leymah Gbowee); “elaboração de projetos, planejamento de intervenções

\footnotetext{
30 Os Parâmetros Curriculares Nacionais, ao propor uma educação comprometida com a cidadania, elegeram, baseados no texto constitucional, princípios segundo os quais orientam a educação escolar: dignidade da pessoa humana, igualdade de direitos, participação, co-responsabilidade pela vida social. (BRASILl, 1997).
} 
pedagógicas" (Tawakel Karman); "aulas diferenciadas, dinâmicas, interatividade e algumas outras atividades voltadas para a ressocialização dos mesmo" (Wangari Muta Maathai); "experiências, aulas expositivas, filmes motivacionais, trabalhos em grupos" (Juan Manuel Santos).

Dentre as principais dificuldades encontradas no cumprimento das atribuições docentes naquela escola, os professores destacaram: falta de interesse pelos estudos por parte dos alunos, poucos recursos didáticos para aplicação de conteúdo de forma mais ampla e não utilização de alguns recursos por motivos de segurança.

Por fim, apresento alguns dados no mínimo intrigantes, ao responderem quantos dos alunos daquela escola acreditavam que concluiriam o ensino médio e também quantos fariam um curso superior. Surpreendentemente, nenhum professor respondeu 'quase todos' ou 'um pouco mais da metade'. Cinco professores responderam 'poucos alunos', um professor respondeu 'um pouco menos da metade' e um professor respondeu 'não sei'. Especificamente, ao fato de acreditarem que seus alunos entrariam em alguma universidade, além da resposta apresentadas, curiosamente um professor acrescentou um tópico que não existia na pergunta e respondeu 'nenhum'.

Foi possível observar através das respostas apresentadas pelas professoras e professor, um comprometimento e respeito pelo trabalho que exercem na Unidade, dadas as devidas particularidades. No entanto, acredito que os resultados poderiam ser mais eficientes se os docentes articulassem seus planos de aula ou os projetos realizados ali, de forma coletiva. A troca de informações entre eles e o planejamento coletivo poderia ajudar a dirimir possíveis problemas. São os professores que reportam aos adolescentes as informações, do lado externo da unidade, sobre os acontecimentos políticos, econômicos, culturais e todo tipo de entretenimento.

Outro ponto importante que acredito contribuir na qualidade do trabalho e principalmente na influência direta com os adolescentes, está na capacitação e aperfeiçoamento dos/as docentes. Isso contribui até mesmo na melhor seleção dos conteúdos e nos mais significativos para a realidade de cada aluno. Argumento esse sustentado no entendimento de Nóvoa (1995) o qual diz que a formação de profissionais que atuam na educação deve ser preocupação central, pois

[...] Educar e ensinar é, sobretudo, permitir um contato com a cultura, na acepção mais geral do termo; trata-se de um processo em que a própria experiência cultural do professor é determinante. Portanto, a formação tem que ser repensada, pois há maior incidência nos 
aspectos técnicos da profissão do que nas dimensões pessoais e culturais. (NÓVOA, 1995, P.67).

De modo geral, os professores e professoras que trabalham com adolescente em conflito com a lei precisam compreender que o trabalho que desenvolvem exige um olhar e atenção diferente do dispensado a outros alunos. Que este mesmo trabalho pode modificar tanto a unidade quando o adolescente. E entendo que isso não é segregar ou atribuir preconceito a eles. O papel dos professores e professoras contribui diretamente no processo de (re)socialização do adolescente, para que este, enquanto excluído, possa ser ouvido e fazer-se ouvir e tenha direito de desfrutar de uma educação democrática. (GENTILI, 1995).

\subsection{Os adolescentes privados de liberdade: perfil social, econômico e educacional}

Neste tópico se concentram todos os esforços de expor ao leitor, de maneira fiel, os resultados propostos no objetivo geral deste trabalho que tem o comprometimento de compreender a percepção que os adolescentes privados de liberdade, na Unidade de Atendimento Socioeducativo de Unaí - MG possuem quanto a formação que recebem e

o processo de (re)socialização que estão sujeitos. É um esforço em dar voz e vez a estes adolescentes, não eximindo-os de suas responsabilidades e consequências que os levaram a estar ali, mas permitindo que se expressem diante das políticas e práticas educacionais que lutam em prol da dignidade e resgate da autonomia e cidadania.

A realização da coleta de dados, conforme dito em tópicos anteriores, ocorreu no dia 26 de junho de 2017, no período matutino e vespertino. Naquela data a Unidade contava com 102 adolescentes internados, cumprindo medida socioeducativa de internação. A distribuição física dos adolescentes na Unidade acontece em dois núcleos, identificados como Núcleo 01 e Núcleo 02. Essa divisão não permite o contato entres os internos de núcleos diferentes. De acordo com a direção pedagógica, esta divisão não segue necessariamente um critério, mas aproveitam a sua existência para colocarem separados adolescentes que por ventura tenha algum tipo de rivalidade ou o que os adolescentes chamam de "guerra" fora da unidade.

O critério utilizado para selecionar os adolescentes que participariam diretamente da pesquisa foi selecionar alunos do ensino médio. Os adolescentes nessa fase escolar, em tese, já estariam mais próximos de saírem da Unidade, comparado com 
os adolescentes do Ensino Fundamental e assim, compreender os projetos de vida desses sujeitos estaria mais próximo do que se propôs a pesquisa.

Os adolescentes matriculados na escola do Núcleo 01 foram selecionados, por ser um quantitativo menor e suficiente para se chegar aos objetivos. Os protocolos de segurança que os agentes e os demais profissionais estão sujeitos são muito rígidos. A escolha desse quantitativo menor foi para evitar que gerasse no momento das entrevistas e aplicação de questionário algum tipo de tumulto ou desordem no local.

O Núcleo 01, na data referência, contava com uma turma do primeiro ano, uma turma do segundo ano e uma turma do terceiro ano do ensino médio, com dez, quatro e dois alunos respectivamente. $\mathrm{Na}$ data da visita à Unidade, dois alunos haviam conseguido um benefício judicial e teriam saído temporariamente para visitarem seus familiares, participando assim apenas quatorze adolescentes.

Os adolescentes, das três séries distintas, foram reunidos em uma única sala, na presença de alguns agentes socioeducativos que a todo tempo ficaram presentes. Foi apresentado a eles a proposta da pesquisa, os objetivos, a importância da participação de cada um e o convite para responderem ao questionário e entrevista que aconteceria em outro momento. Nenhum dos adolescentes se opôs e todos os cuidados foram tomados para que não se sentissem coagidos e pressionados para participarem. Os adolescentes foram também informados que poderiam deixar de participar a qualquer momento, tendo apenas que comunicar à direção da Unidade.

Como dito, no período da manhã foi realizada aplicação de questionário com todos os adolescentes, ao mesmo tempo, reunidos em uma única sala. No período da tarde, eles foram entrevistados individualmente em outra sala, sem a presença dos agentes socioeducativos próximos.

Foram levantados dados quantitativos e qualitativos que possibilitaram vislumbrar e traçar o perfil do adolescente privado de liberdade na Unidade de Unaí. Esse tema não deve ser tratado de maneira simplificada e lança-se por terra qualquer tentativa de evocar falsas relações de causa e consequência, como pobreza, cor da pele, estrutura familiar, baixa escolaridade ou demais associações ideológicas. O objeto desta pesquisa é bastante complexo e exige-se que ao ser analisado tenha uma sensibilidade para com o tema e se esvazie de qualquer (pré) concepção.

A seguir serão apresentados alguns dados relevantes que permitiram caracterizálos quanto ao perfil social, econômico e educacional. Estas características são 
importantes no primeiro momento, pois é através delas que poderemos contextuar de quem, sobre quem e com quem estamos falando. Outro ponto importante é que estes dados podem futuramente servir de comparativo com outras Unidades espalhadas pelo país e contribuir com os diagnósticos sobre perfil de adolescentes em conflito com a lei.

Em consonância com o Estatuto da Criança e do Adolescente - ECA e ao princípio da Doutrina de Proteção Integral, será preservada a identificação destes adolescentes em todo trabalho. Alguns trechos de falas foram transcritas adiante para elucidar alguns apontamentos que serão feitos, mas não serão utilizados seus nomes verdadeiros. Para identifica-los serão utilizados nomes fictícios, retirados da lista divulgada no ano de 2015 pela revista americana de economia Forbes, com o nome dos 30 jovens ${ }^{31}$ mais influentes na educação, responsáveis por mudar a maneira de ensinar e aprender. Foram utilizados os 14 primeiros nomes masculinos apresentados na lista: Alex Klein - criador do Kano, computador que você pode construir e programar como bem entender; Karim Abouelnaga - fundador da Practice Makes Perfect, empresa que oferece programa de mentoria para ajudar alunos em recuperação durante o verão; Michael J. Carter - fundador da Strive for College, plataforma de mentoria virtual; Jason Deroner, Andrew Gioial e Michael Gioia - criadores do TeachBoost, plataforma de gestão escolar e de redes; Jeremy Friedman, Ryan-Hwang, Bill Kindler e Timothy Trinidad - criadores da plataforma de ensino online Schoology; Mattan Griffel - cofundador do site de aulas de programação OneMonth; Dan Johnston - cofundador da InstaEDU, site de tutoria online; Benjamin Levy - Cofundador da eduCanon, plataforma de vídeos que permite a professores criarem sua própria Khan Academy; Zak Ringelstein - co-fundador da Uclass, site de apoio a gestores e professores.

A unidade é exclusiva para adolescentes do sexo masculino e todos os internos participantes da pesquisa residiam, ou são de cidades próximas a Unaí, antes de irem para o local. Dos quatorze adolescentes, 13 são naturais do estado de Minas Gerias e apenas 01 do Distrito Federal.

De acordo com a definição do Instituto Brasileiro de Geografia e Estatística IBGE, cor ou raça é característica declarada pelas pessoas de acordo com as seguintes opções: branca, preta, amarela, perda ou indígena. Nesse sentido, observam-se que $50 \%$

\footnotetext{
${ }^{31}$ Disponível em: https://educacao.uol.com.br/noticias/2015/01/07/forbes-lista-30-jovens-mais-influentesna-educacao.htm
} 
se declararam de cor parda, $21 \%$ de cor negra, $21 \%$ de cor branca e apenas 01 que se considera amarelo.

Quanto à faixa etária do grupo pesquisado, na data de referência, quatro estavam com 16 anos, quatro com 17 anos, quatro com 18 anos e dois com 19 anos de idade. Os fato de alguns adolescentes já terem atingido a maioridade e ainda estarem na Unidade, justifica-se por terem iniciado o cumprimento da medida de internação antes dos 18 anos e conforme o parágrafo $5^{\circ}$ do artigo 121 do ECA, a liberação só é compulsória aos vinte e um anos de idade (BRASIL, 2016).

Sobre a renda familiar, $64 \%$ não souberam responder e $28 \%$ disseram ter uma renda familiar de apenas 01 salário mínimo. Seis adolescentes relataram que suas famílias recebem algum benefício do governo, quatro disseram que não e quatro não souberam responder. A maioria deles (10) mora em casa própria. Questionados sobre com quem viviam antes da prática do ato infracional e da internação, 57\% dos adolescentes responderam que residiam apenas com suas mães e $28 \%$ residiam em um núcleo familiar composto por mãe e pai.

Em pesquisa intitulada Estudos do Sistema Socioeducativo para Adolescentes autores de atos infracionais no Estado de Goiás (Sousa et al., 2009) uma entrevista realizada com os familiares dos adolescente, revelou dados semelhantes, com predomínio de apenas mães compondo o núcleo familiar. Segundo esta pesquisa, as mães acabam por assumir sozinhas as responsabilidades pela criação e educação dos filhos, por circunstâncias diversas como aprofundamento da pobreza das famílias, abandono do genitor e redução de pessoas na geração de renda familiar. As mães, em muitos casos, são as únicas responsáveis pela organização e manutenção da casa, pelo suprimento das necessidades básicas e educação dos filhos.

É preciso romper com os paradigmas que não consideram as famílias de classes populares como legítimas educadoras, incompetentes e incapazes de zelar pela criação dos filhos. Sousa e Peres (2002) ao discutirem sobre a multiplicidade de arranjos familiares, principalmente na atualidade com diversas composições e características discorrem que "a família é o espaço indispensável para a garantia da sobrevivência, de desenvolvimento e de proteção integral dos filhos e demais membros, independente do arranjo familiar ou da forma como esteja estruturada" (SOUSA; PERES, 2002).

Este fato também ratifica o resultado obtido quando os adolescentes internados na Unidade de Unaí - MG foram questionados se exerciam alguma atividade 
remunerada antes da internação, mesmo que informalmente, sendo que $71 \%$ responderam que sim. As atividades citadas foram todas do mercado informal, sem vínculo empregatício: servente de pedreiro, carpinteiro, pintor, mecânico, atividades rurais, vendedor de 'geladim', vendedor de roupas e lavador de carro.

Os dados e de outras pesquisas que tem como objeto estes sujeitos, fica nítido as relações sociais e econômicas que permeiam a vida dos adolescentes em conflito com a lei. É possível inferir que a característica econômica predominante destes adolescentes é pertencerem a famílias de baixo poder aquisitivos, quando não em situações de miséria e vulnerabilidade. Contudo é importante ressaltar que atos infracionais não são cometidos apenas por eles, como exemplifica Volpi (2011, p. 118)

[...] A composição familiar e o grupo social ao qual pertencem os adolescentes em conflito com a lei não são apenas um dado objetivo, mas também uma produção social, política e ideológica. [...] ao analisarmos os processos na Justiça da Infância e da Juventude observamos que a prática de delitos ocorre em todas as classes sociais. A resposta social é que é diferente para cada caso.

Na minha experiência como escrivão de polícia e, no contato direto com muitos adolescentes que passam pela Unidade de Polícia, apreendidos pela prática de algum ato infracional é possível afirmar por meio dos relatos dos próprios adolescentes que, trabalhar para estes sujeitos está implícito vários significados. Um deles é o fato de acreditarem, ou seus responsáveis acreditarem que, se trabalharem ficará longe das drogas, das más companhias e consequentemente do ato infracional. Há aqueles que trabalham apenas para sustentar os vícios nas drogas ilícitas e os que trabalham para ajudar suas famílias na complementação da renda familiar.

Com certa frequência alguns pais questionam as leis trabalhistas e o próprio ECA, que preservam a integridade do adolescente, limitando-os a certos trabalhos e horários. Muitos pais acreditam que as empresas, em decorrência das restrições sobre menores de idade, impostas pela legislação trabalhista, com as devidas exceções legais, não contratam os adolescentes em atividades formais. A ausência de escolaridade em quase todos os casos contribui para que encontrem apenas trabalhos braçais ou na informalidade. A grande questão que se forma no que tange ao fato do adolescente trabalhar está no abandono da sala de aula que quase sempre acontece com todos.

Ainda na seara do perfil social, a pesquisa revelou que todos os adolescentes já tiveram contato com drogas ilícitas e onze deles, já fizeram ou fazem uso de bebidas 
alcoólicas. Um dado preocupante e que chama a atenção é o momento da iniciação: 01 adolescente teve seu primeiro contato aos 10 anos de idade; 02 adolescentes aos 12 anos; 04 adolescentes aos 13 anos, 02 adolescentes aos 14 anos e 05 adolescentes aos 15 anos de idade.

A relação dos adolescentes atores de ato infracional com as drogas necessita de um olhar mais apurado. Apesar de nem sempre predominar nas infrações cometidas por adolescentes, as drogas, na maioria das vezes servem como porta de entrada para as práticas dos demais atos infracionais. Na minha experiência como escrivão de polícia judiciária, durante os plantões na Delegacia de Polícia Civil onde são apreendidos quase que diariamente adolescentes em conflito com a lei, com raras exceções, quase todos os adolescentes estão intimamente relacionados com as drogas, com o consumo ou com o tráfico. A manutenção do vício e o efeito do entorpecente "estimulam" o adolescente a cometer outras infrações (furto, roubo).

No mínimo duas vezes os adolescentes já foram apreendidos e conduzidos a uma Unidade de Polícia Civil (Delegacia) ao serem questionados quantas vezes isso ocorreu. Alguns dos adolescentes (57\%) ainda acrescentaram no questionário que foram tantas ocasiões que já não sabiam ou não recordavam o número de vezes com exatidão que teriam sido apreendidos. Os crimes contra o patrimônio lideram os atos infracionais mais praticados por adolescentes em conflito com a lei, o que pode ser comprovado no gráfico a seguir que mostra a porcentagem destes atos no Brasil, no levantamento feito pelo Sinase. 


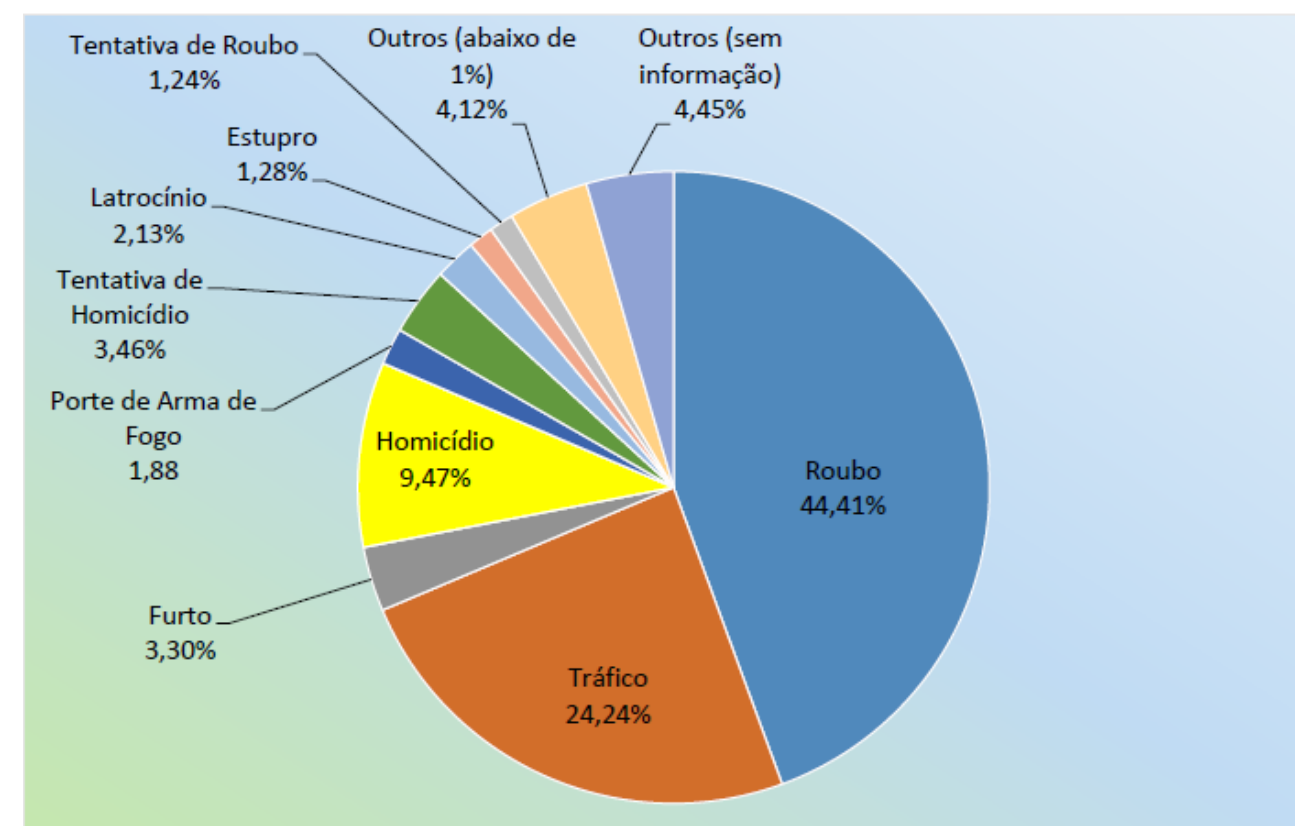

FIGURA 08 - Atos Infracionais - Total Brasil (2014)

Fonte: Levantamento SINASE 2014.

A predominância dos crimes contra o patrimônio ${ }^{32}$, entre os atos infracionais cometidos por adolescentes, levanta uma discussão que encontra respaldo na atual conjuntura da sociedade capitalista, que adestra a grande massa ao consumismo exacerbado e ao discurso da "vida feliz" através das roupas de marca, dos melhores calçados, celulares de última geração, etc. Os adolescentes atores de atos infracionais, que na maioria das vezes são das camadas mais pobres da sociedade, não tem acesso a todo esse panorama de consumo franqueado pela mídia e pela publicidade. Castro e Guareschi (2007) enfatizam que

[...] Os jovens provenientes das camadas mais pobres sofrem particularmente porque são excluídos do acesso direto às marcas mais caras do mercado e das políticas públicas capazes de, ao menos, criar uma expectativa razoável de inserção nele. Assim, a violência pode ser pensada como uma forma de resistir às injustiças e ascender ao mundo do consumo. (CASTRO; GUARESCHI, 2007, s/p).

De certa forma, estes adolescentes encontram nesses crimes um meio de serem vistos e percebidos pela sociedade. Uma espécie de afirmação ou simplesmente uma demonstração de revolta, ou como diria Oliveira (2001) o ato infracional cometido pelo adolescente pode ser visto como busca de reconhecimento e de autonomia. A escola,

\footnotetext{
32 Os crimes contra o patrimônio estão descritos no Título II da parte especial do Código Penal Brasileiro. Considera-se patrimônio de uma pessoa, os bens, o poderio econômico, a universalidade de direitos que tenham expressão econômica para a pessoa.
} 
que deveria garantir, ou pelo menos possibilitar um mecanismo de ascensão social e profissional, acaba não suprindo essa demanda e cruelmente, atribui ao adolescente, e apenas a ele, a responsabilidade por sua condição social e pelo seu futuro.

Os adolescentes foram questionados se já teriam sido submetidos a outras medidas socioeducativas que não fosse a de internação e $42 \%$ (06) responderam que sim. Ainda foram questionados sobre quantas vezes já teriam sido submetidos a medida socioeducativa de internação e o resultado mostrou que quase todos do grupo, com exceção de 01 adolescente, estavam ali pela primeira vez.

Outro aspecto relevante que o questionário possibilitou inferir foi o perfil educacional dos adolescentes, antes de entrarem na unidade. Como exigência da medida de internação, o adolescente é obrigatoriamente encaminhado à educação formal, às atividades profissionalizantes, esportivas, culturais e de lazer. Todos os quatorze adolescentes que participaram da pesquisa possui Ensino Médio incompleto. Unanimemente, todos antes de ingressarem na Unidade, estudaram apenas em escolas da rede pública.

Foram solicitados a responderem se algo os fazia ter vontade de ir para escola. Apenas três respostas revelaram certo vínculo com escola, quando relataram que tinham vontade de ir à escola "para aprender coisas", "ter mais aprendizado e um emprego melhor" e "terminar os estudos". Um dos adolescentes respondeu que a sua motivação para ir à escola era para "fumar maconha". Os demais responderam "ver as garotas", "as meninas".

Quando a maioria desses adolescentes responde que "as meninas", "as garotas" eram sua motivação para irem a escola, ratifica os estudos de Caurel (2003) que analisou como o adolescente em conflito com a lei vê a escola. Para este autor, o ambiente escolar é visto pelos adolescentes, atores de ato infracional, como um espaço socialmente rico, porém consideram a escola como um local desinteressante e como algo negativo o estar em sala de aula. De acordo com Caurel (2003) as lembranças dos adolescentes que participaram do seu estudo eram apenas das chamadas "bagunças" e dos momentos de descontração na escola com os demais alunos.

Através de uma revisão da literatura é possível inferir que as experiências escolares de adolescentes em conflito com a lei são marcadas por constantes mudanças de escolas, conflitos com professores e colegas, expulsões, discriminações entre outros fatores. Mesmo com o ordenamento jurídico tendo a visão dos adolescentes como 
sujeitos de direitos, e a educação e o acesso à escola, como garantia de um desses direitos, ainda há grande dificuldade em efetivar o direito à educação, principalmente aos adolescentes atores de ato infracional. Pesquisas em âmbito nacional têm indicado que o fenômeno do fracasso e da evasão escolar é comum entre adolescentes em conflito com a lei. (DIAS; ONOFRE; 2013).

Para Assis, Deslandes e Santos (2005) em uma referência à ilustre obra de Bourdieu e Passeron (1978) apontam a escola como um espaço primordial de socialização e de preparação de crianças e adolescentes para a vida, mas que também pode habitar um lócus de violência. Isso ocorre quando ignora as habilidades e competências das crianças e adolescentes das classes pobres, atribuindo um conjunto de atitudes, comportamentos e características das classes dominantes, fazendo-os acreditar que são incapazes de aprender ou competir.

Foram perguntados também se já teriam feito algum curso profissionalizante antes da internação e se participavam ou participaram de algum projeto educacional/social desenvolvido na escola de origem ou em outro espaço na comunidade. Os dados revelaram que $50 \%$ dos alunos já teriam feito algum curso profissionalizante e $50 \%$ não. Revelou ainda que $50 \%$ já teriam participado de algum projeto antes de ingressarem naquela unidade, $28 \%$ não e $21 \%$ não lembravam.

A maioria dos adolescentes (92\%) respondeu que possuem hábito de leitura e a mesma porcentagem respondeu gostar de ler. Não se sabe e não foi possível inferir se o hábito de leitura é uma determinação da unidade e faz parte das práticas educacionais. Mas acredito que leitura seja uma prática desenvolvida com os alunos e que eles desenvolvem o hábito de leitura ao preencherem o tempo ocioso. A mesma porcentagem também (92\%) respondeu ter acesso à internet antes da internação, sendo diversos tipos de acesso citados, como celular próprio, laboratório da escola e lan house.

As perguntas finais do questionário indagavam aos adolescentes se os professores, das escolas que frequentavam antes da internação, estimulavam a continuidade dos estudos. A maioria, 57\%, respondeu que todos estimulavam, 35\% responderam que a maior parte dos professores estimulava e apenas um aluno respondeu que poucos professores estimulavam. Perguntados ainda se já teriam relatado para algum professor ou professora e buscado ajuda sobre algum problema pessoal, $85 \%$ responderam que não e apenas $15 \%$ responderam que sim. 


\subsection{A percepção dos adolescentes quanto ao processo de formação e (re)socialização}

Antes de iniciarmos a discussão proposta para este tópico, que inclusive é o cerne desta pesquisa, faz-se necessário trazer ao leitor uma breve apresentação sobre a rotina e funcionamento de um centro de atendimento socioeducativo. A Unidade consiste no local onde os adolescentes, atores de ato infracional são direcionados, após decisão do poder judiciário. O trabalho desenvolvido nas Unidades é formado por uma múltipla rede de profissionais capacitados, desde pedagogos, professores, agentes socioeducativos, psicólogos, assistentes sociais, agentes de saúde, agentes religiosos, etc.

As atividades seguem um cronograma que possibilita que o adolescente seja atendido e impactado pela proposta principal que é a promoção de sua autonomia, formação e a (re)socialização com a experiência e contribuição de cada área. Por não se limitar apenas as salas de aulas e atribuir somente a figura do professor essa responsabilidade, as atividades extraclasses desempenham nas Unidades uma função educativa de singular importância. Ajudam a desenvolver as potencialidades dos adolescentes e despertar ou criar novas habilidades com objetivo de transformá-los.

As entidades que desenvolvem programa socioeducativo de internação possuem algumas obrigações que são elencadas no artigo 94 do ECA. São elas:

I - observar os direitos e garantias de que são titulares os adolescentes; II - não restringir nenhum direito que não tenha sido objeto de restrição na decisão de internação;

III - oferecer atendimento personalizado, em pequenas unidades e grupos reduzidos;

IV - preservar a identidade e oferecer ambiente de respeito e dignidade ao adolescente;

V - diligenciar no sentido do restabelecimento e da preservação dos vínculos familiares;

VI - comunicar à autoridade judiciária, periodicamente, os casos em que se mostre inviável ou impossível o reatamento dos vínculos familiares;

VII - oferecer instalações físicas em condições adequadas de habitabilidade, higiene, salubridade e segurança e os objetos necessários à higiene pessoal;

VIII - oferecer vestuário e alimentação suficientes e adequados à faixa etária dos adolescentes atendidos;

IX - oferecer cuidados médicos, psicológicos, odontológicos e farmacêuticos; 
X - propiciar escolarização e profissionalização;

XI - propiciar atividades culturais, esportivas e de lazer;

XII - propiciar assistência religiosa àqueles que desejarem, de acordo com suas crenças;

XIII - proceder a estudo social e pessoal de cada caso;

XIV - reavaliar periodicamente cada caso, com intervalo máximo de seis meses, dando ciência dos resultados à autoridade competente;

$\mathrm{XV}$ - informar, periodicamente, o adolescente internado sobre sua situação processual;

XVI - comunicar às autoridades competentes todos os casos de adolescentes portadores de moléstias infecto-contagiosas;

XVII - fornecer comprovante de depósito dos pertences dos adolescentes;

XVIII - manter programas destinados ao apoio e acompanhamento de egressos;

XIX - providenciar os documentos necessários ao exercício da cidadania àqueles que não os tiverem;

XX - manter arquivo de anotações onde constem data e circunstâncias do atendimento, nome do adolescente, seus pais ou responsável, parentes, endereços, sexo, idade, acompanhamento da sua formação, relação de seus pertences e demais dados que possibilitem sua identificação e a individualização do atendimento. (BRASIL, 2016, p. 24).

A pretensão neste tópico é de discutir, numa perspectiva interpretativa, os discursos dos adolescentes que se encontram privados de liberdade, cumprindo medida socioeducativa no Centro de Atendimento Socioeducativo de Unaí - CSEUN, conforme as prerrogativas do Estatuto da Criança e do Adolescente - ECA.

Tais discursos foram inferidos a partir de entrevista realizada com um grupo de 14 adolescentes, regularmente matriculados no ensino médio, com representantes das três séries - primeira, segunda e terceira séries do ensino médio. O principal objetivo com a realização da entrevista, aplicada individualmente em uma sala onde o adolescente pudesse se sentir à vontade e seguro para falar, foi fazer com que cada um trouxesse à tona a sua percepção quanto a realidade de estar privado de liberdade e como veem o processo de formação e (re)socialização desenvolvido naquela unidade.

Este texto se ampara na concepção de entrevista apresentada por Manzini (2003, p.13) que a define como "uma forma de buscar informações, face a face, com um entrevistado (...) uma conversa orientada para um objetivo, sendo esse objetivo estabelecido pelo pesquisador". Diante das várias formas de entrevista a utilizada foi a semiestruturada, que tem como uma de suas características a elaboração prévia de um roteiro, que funciona como auxílio para o pesquisador se organizar antes e no momento 
da entrevista e/ou auxílio indireto ao entrevistado, que fornece informações de forma mais precisa e com facilidade. (MANZINI, 2003). A entrevista semiestruturada oferece também as perspectivas para que os entrevistados alcancem a liberdade e a espontaneidade necessárias, enriquecendo ainda mais a investigação.

Como recurso para a coleta dos dados, optou-se pelo uso de entrevistas gravadas ${ }^{33}$ seguindo um roteiro com 33 perguntas. As perguntas foram adequadas à linguagem dos sujeitos entrevistados e com cuidado ainda maior de não os expor ou constrangê-los face aos atos infracionais cometidos e as condições que se encontravam. Mesmo com a proposta de roteiro previamente estabelecido, a entrevista seguiu permitindo uma flexibilidade no momento da gravação. Zago (2003, p.295) define essa flexibilidade na entrevista como "compreensiva", pois "não possui uma estrutura rígida, isto é, questões previamente definidas podem sofrer alterações, conforme o direcionamento que se quer dar às investigações".

Foi possível assim, ouvir de cada adolescente, seus sonhos de mudança, seus anseios, medos, aflições, projetos de vida e o que as aulas e o trabalho da equipe multidisciplinar, podem contribuir na formação de cada um. Desta forma, destaca-se no conteúdo da entrevista questões que está intrinsicamente ligadas a rotina dos adolescentes privados de liberdade, tais como: o momento em que cometeram o primeiro ato infracional, a reação da família, o envolvimento com a droga, a "motivação" para as práticas infracionais, como avaliam o trabalho dos professores e se acredita que ele contribui para a sua formação e (re)socialização, entre outros que serão expostos a seguir.

O início de cada entrevista foi sempre cuidado, procurando fazer com que os adolescentes se sentissem a vontade naquela situação e também procurando resguardar a dignidade dos mesmos, sempre amparado nos princípios do ECA. Neste cuidado, procurou-se explicar para cada um os objetivos da pesquisa e a importância das respostas para as questões que seriam formuladas. Em alguns casos, perceberam-se logo no início alguns questionamentos do tipo: "se eu participar disso vai influenciar na minha saída?". Na realidade, no primeiro contato eles queriam sabem "quem eu era" e se aquilo era realmente uma pesquisa de mestrado.

\footnotetext{
${ }^{33} \mathrm{Nem}$ todas as falas dos adolescentes foram transcritas neste trabalho, na apresentação das questões abordadas na entrevista. Isso se deu pelo fato de alguns não terem respondido ou apenas responderam "sim", "não". Além disso, algumas respostas foram idênticas e para evitar repetições, nem todas foram transcritas.
} 
O roteiro da entrevista iniciou perguntando a cada adolescente o tempo em que estava na Unidade, se era a primeira vez que estava ali e se já teria cumprido outro tipo de medida socioeducativa prevista no ECA. Dos 14 adolescentes entrevistados, 10 estão há mais de 01 ano na unidade e os demais apenas alguns meses. Para 10 adolescentes é a primeira vez no local, 01 adolescente é reincidente e 03 receberam benefício judicial de visitarem suas famílias e na oportunidade não retornaram, ficando foragidos por um tempo e só retornaram ao serem capturados pela polícia. Quatro destes adolescentes já teriam cumprido a medida socioeducativa de Liberdade Assistida (Artigo 118 do ECA) antes da de Internação.

Durante a entrevista foi perguntado aos adolescentes se conheciam ou já tinham ouvido falar sobre a Lei 8.069/90 - Estatuto da Criança e do Adolescente - ECA. Nenhum deles afirmou conhecer o ECA. As falas foram unânimes em dizer apenas que “já ouviram falar". Apenas um adolescente teria exposto o fato de ter manuseado e lido a referida legislação: “eu tinha esse livrinho, já li algumas coisas” (Zak Ringelstein).

De modo geral, o ingresso de adolescentes às práticas de atos infracionais acontece precocemente, já nos primeiros anos da adolescente, com raras exceções. Como já exposto neste trabalho, os principais fatores que aumentam a vulnerabilidade para a prática de ato infracional são os fatores individual, relacional, comunitário e social (KRUG, 2002; BRASIL, 2005). Como serão apresentados a seguir, estes fatores foram ratificados após a entrevista, principalmente os fatores relacional e comunitário.

Três perguntas foram fundamentais no momento da entrevista, dentro deste contexto: qual a idade tinha ao cometer o primeiro ato infracional; o que influenciou ou contribuiu para que cometesse o ato infracional; qual foi a reação da família. Um adolescente alegou ter cometido o primeiro ato infracional aos 11 anos, três adolescentes aos 13 anos, cinco adolescentes aos 14 anos, quatro aos 15 anos e um adolescente aos 17 anos de idade.

Sobre os fatores que influenciaram ou contribuíram para a prática de ato infracional, foi possível analisar na maioria das falas que "as amizades" e "a falta de dinheiro" são os principais argumentos dado por eles. Isso vai ao encontro dos fatores expostos pela OMS (BRASIL, 2015). Algumas falas foram destacadas: "falta de dinheiro; eu trabalhava antes sabe, só que o patrão atrasava o mês e tinha conta pra pagar; comprava uma roupa a prazo, queria comprar um perfume, esses trem" (Karim Abouelnaga); "cabeça fraca minha, indo em pino dos outros, companhia, amizades" 
(Michael Gioia); “minha família nunca me deu um bom exemplo assim não; minha mãe, desde quando eu tinha oito anos que ela estava presa; meu pai esta preso; ai entrei também" (Bill Kindler); "sei não...tipo assim, dinheiro, não tinha dinheiro e não tinha serviço; teve os amigos que falavam comigo... bora lá comigo sô”. (Benjamin Levy); "indignação com a vida; revolta com o meu pai, ele nunca cuidou de mim, nunca me deu nada; amigos da escola, começou na escola" (Zak Ringelstein).

Sobre a reação das famílias: "foi um choque, um desapontamento" (Karim Abouelnaga); "eu fui preso essa primeira vez, ai eles assinou e eu fui embora; chegou lá eu apanhei e escutei um sabão; eles ficou com raiva, vergonha" (Michael J. Carter); "ficou meio pesada né; tipo assim, não foi a reação mais agradável; tomaram um susto; me levaram na psicóloga; a juíza decretou da primeira vez que eu roubei” (Jason Deroner); "ficou pasma na hora que ficou sabendo que tinha sido eu" (Bill Kindler); "minha mãe ficou brava, me bateu, fez eu devolver as coisas" (Benjamin Levy).

Os adolescentes também tiveram a oportunidade de expressarem como avaliam o trabalho dos professores na sala de aula. Todos atribuíram características positivas a atuação dos docentes e ficou muito evidente o sentimento de respeito e valorização deste profissionais. Alguns alunos ainda ressaltam o fato de serem melhor assistidos durante as aulas na Unidade, o que não vivenciavam quando estavam em outras escolas fora daquele contexto.

Alguns apontamentos relevantes sobre o trabalho dos professores: "eles trabalham tranquilo; faz o trabalho deles certinho; eles estão aqui pra ajudar nós" (Alex Klein); "tranquilo; porque antes lá fora não chegava neles pra perguntar, agora se chegar e perguntar se eu tiver dúvida eles vem e tira normalmente" (Michael J. Carter); "bom serviço porque eles explicam bem explicado; ai tenta fazer o possível pra gente aprender" (Jason Deroner); "muito bem feito; porque o trabalho deles eles querem ensinar e quer que a gente prossiga nos estudos" (Michael Gioia); “de boa; bom o trabalho deles; tá ai pra ensinar nós; todo dia eles levantam cedo pra vim aqui; o trabalho deles é bom" (Benjamin Levy).

Assim, foi possível analisar a relevância e importância que os adolescentes atribuem ao trabalho do professor e, consequentemente, deixam explícito a percepção que tem quanto a formação que recebem. Pode-se afirmar com isso, que a maioria acredita que a escola é um dos caminhos para a (re)socialização. 
Seguindo o roteiro de entrevista, um dos pontos abordados com os adolescentes foi se os temas cidadania, sexualidade, meio ambiente, ética, pluralidade cultural e saúde, classificados como transversais, eram trabalhados pelos professores. A transversalidade é extremamente importante, principalmente neste contexto, onde os alunos possuem liberdade restrita, pois atravessa diferentes campos de conhecimento. Por abordar questões sociais, a complexidade faz com que nenhuma das áreas de conhecimento seja suficiente para tratá-los, criando assim, uma rede de interação entre os docentes em um único propósito. Estes temas caminham por toda a prática educativa que, necessariamente, envolve as relações entre os alunos, entre professores e alunos e entres todos os demais membros da Unidade.

Analisando as respostas dadas pelos adolescentes, estes temas são trabalhados pelos professores e também através de palestras ministradas por ONGs e outros agentes da comunidade. Os únicos temas citados que foram reforçados nas falas de quase todos os alunos foram os de meio ambiente e de sexualidade. Algumas falas em destaque: "trabalha; a gente já teve um curso de sexualidade; meio ambiente é só na matéria mesmo; eu acho bom" (Jeremy Friedman); "trabalha; de vez em quando eles fazem umas palestras; vai todo mundo pra quadra; trabalha tudo; trabalha mais sobre meio ambiente" (Bill Kindler); "sim; esses dias a gente fez um curso ai sobre doenças sexuais; eu concluir o curso todinho; tem palestra e em sala de aula; esses dias pra traz mesmo teve uma palestra sobre meio ambiente e esses trem de cidadania na sala" (Dan Johnston).

Além disso todos os alunos ratificaram que recebem instruções sobre os fatores prejudiciais que as drogas ilícitas trazem. Segundo eles, a maior parte destas orientações acontece através de palestras ministradas por diferentes agentes e até por ex-usuários de drogas. Na fala de um deles: "a gente fez um curso sobre isso; aprende muito; veio uma professora eu acho que lá do DF pra fazer esse curso com nós; a gente aprende altos trem que a gente não sabe sobre droga" (Dan Johnston).

É possível com isso analisar a importância que a parceria entre escola e outros segmentos da sociedade tem nessa relação. Como já exposto, essas parcerias correspondem a um marco considerável da educação social no Brasil se deu na década de 1980 com a promulgação da nova Constituição Federal em 1988, no processo vivido pelo país conhecido como redemocratização. É importante que todos os segmentos da 
sociedade civil passem a buscar soluções de caráter coletivo a fim de atingir o Estado de Bem Estar Social.

É relevante o trabalho feito na Unidade ao abordar o tema drogas e seus malefícios para o corpo e sociedade. As drogas são a porta de entrada para o ato infracional e como os resultados mostraram que todos já tiveram contato e/ou são usuários. Foi possível analisar que todos os adolescentes tem a compreensão do que a droga é capaz de fazer.

Outro exemplo que pode ser incluído nesse contexto corresponde a assistência religiosa que as unidades recebem. A assistência religiosa em estabelecimentos prisionais possui atribuição legal, através da promulgação da Lei 9.982/2000 (BRASIL, 2000). Através das ações, vários seguimentos religiosos levam palavras de conforto, fé e esperança para os adolescentes. Acredito que apenas pelo fato de promover uma reflexão, não fazendo aqui nenhum julgamento de credo ou religião, contribui no processo de (re)socialização. Sobre o tema em questão Mirabete (2002) discorre que

[...] $\mathrm{Na}$ atualidade, a assistência religiosa no mundo prisional não ocupa lugar preferencial nem é o ponto central dos sistemas penitenciários, tendo-se adaptado as circunstâncias dos nossos tempos. Não se pode desconhecer, entretanto, a importância da religião como um dos fatores da educação integral das pessoas que se encontram internadas em um estabelecimento penitenciário, razão pela qual a assistência religiosa é prevista nas legislações mais modernas. Em pesquisa efetuada nos diversos institutos penais subordinados à Secretaria de Justiça do Estado de São Paulo por um grupo de trabalho instituído pelo então Secretário Manoel Pedro Pimentel, concluiu-se que a religião tem, comprovadamente, influência altamente benéfica no comportamento do homem encarcerado e é a única variável que contém em si mesma, em potencial, a faculdade de transformar o homem encarcerado ou livre (MIRABETE, 2002, P.83)

Uma pergunta peculiar e muito relevante feita aos adolescentes foi se eles consideravam importantes as aulas na Unidade e como se sentiam frequentando-as. A obrigatoriedade de ir às aulas é um dos requisitos dentro da medida socioeducativa de internação -parágrafo único do artigo 123 do ECA (BRASIL, 2016), mas um fato que merece destaque foi que nenhum dos entrevistados disse que vão às aulas por serem obrigados. Pelo contrário, o ato de ir as aulas, na visão da maioria dos entrevistados, é um dos momentos que melhor se sentem e os instigam a um processo de reflexão, aprendizado e construção de projetos de vida. Aqui fica evidente a percepção que estes adolescentes têm, de que ir as aulas é importante e contribui na formação dos mesmos. Nenhum deles disse não ser importante frequentar as aulas. 
Algumas falas ratificam este entendimento: "de certo ponto é importante né pra gente não ficar atrasado e tudo, pensar mais direito o que vai fazer" (Jason Deroner); "considero; a única coisa boa que tô tirando de proveio aqui dentro é isso, a escola; o que mais tô gostando; me sinto melhor, mais leve; penso no futuro; que eu posso ser alguém na vida, que agora é só dá mais um passo" (Andrew Gioia); “considero importante; eu me sinto assim, eu indo assim focando assim na aula, quando eu sair daqui prosseguir nos estudos, fazer uma faculdade, ajudar minha família lá fora" (Michael Gioia); “considero importante; eu fico pensando em mudar de vida, formar e começar a trabalhar" (Jeremy Friedman); "sim; me sinto que tô correndo atrás pra mim aprender; tô com força de vontade pra aprender" (Mattan Griffel).

Outra pergunta primordial, para a construção do entendimento da perspectiva que esses adolescentes tem sobre o processo de formação e (re)socialização, foi se acreditam que o trabalho dos professores e de toda a equipe de profissionais lotados na Unidade é satisfatório e contribui para tal. Todos os adolescentes manifestaram satisfação favorável diante do trabalho realizado por cada professor e demais profissionais.

Todas as aplicações de metodologias desenvolvidas na Unidade, sem dúvida, têm como um dos principais objetivos a proposta de (re)socialização dos adolescentes ali inseridos. Desenvolver projetos de vida com esses adolescentes significa auxiliá-los na elaboração de um olhar intrépido, na construção da identidade, na valorização da diversidade, fundamentada e ampliada sobre o futuro de cada um.

É fundamental que cada adolescente realize atividades de autoconhecimento, de reflexão e busque informações que os levem gradativamente a pensar no futuro que os espera ao encerrarem o cumprimento da medida socioeducativa de internação. Por este motivo, o roteiro de entrevista abordou também sobre os projetos de vida de cada adolescente, com destaque para os projetos quanto aos estudos, ao trabalho, nos relacionamentos amorosos e como planejavam a relação com a família, amigos e comunidades ao retornarem para o seio destes.

Os projetos de vida podem possibilitar ao adolescente a percepção de si mesmo em meio à diversidade e ao contexto vulnerável e infracional que advinham, encarandoos como algo singular, a fim de que desenvolva a capacidade de melhor entender e se enxergar na sociedade, a partir de leituras mais abrangentes. Através da análise das entrevistas foi possível compreender e afirmar que o trabalho na unidade tem levado os 
adolescentes a pensarem sobre o futuro. A fala de todos os entrevistados trouxe explicitamente o desejo de mudança, de concluir os estudos, arrumar um trabalho e de dar "orgulho" as suas famílias. Alguns chegaram até a mencionar que mudariam de cidade para recomeçarem suas vidas em virtude das "guerras" nas cidades de origem, com outras pessoas ou facções criminosas.

Sobre os projetos de vida, destaco a seguir algumas falas: "eu quero mudar de vida; dar orgulho a minha mãe; minha mãe tá sofrendo demais comigo aqui no presídio; pretendo continuar os estudos; terminar e fazer uma faculdade de Direito" (Alex Klein); "terminar o terceiro ano (...) ir para outra cidade na casa de uma tia minha (...) eu tenho problema na cidade, guerra; se for pra eu estudar e pagar CREAS os caras vão me matar" (Andrew Gioia); “quando sair daqui, eu já vi que crime pra mim eu não quero não; quero ficar na minha de boa na minha casa (...) eu vou caçar um lugarzinho pra mim, um parente, ficar de boa; vou sair daqui quero terminar o terceiro" (Ryan-Hwang); “eu quero tentar achar um serviço bom pra mim ai e construir minha família; tenho uma namorada; quero terminar os estudos, já to no primeiro ano do ensino médio, quero terminar" (Bill Kindler); "se eu for ficar em (...) não pretendo estudar la não, só se eu for embora, lá é cheio de guerra; se eu for embora, planejo ir para a casa de um tio (...) lá eu quero estudar, terminar os estudos, faculdade quero fazer engenharia" (Timothy Trinidad); "pensando em sair daqui, ficar mais tranquilo e não me envolver nas mesmas companhias; procurar não cometer os mesmos erros; pretendo terminar esses estudos meu logo e vê se consigo arrumar um serviço" (Mattan Griffel).

Sobre como acreditam que será a relação com a família, amigos e comunidade ao saírem da unidade: "vai ser melhor; o que eu fiz eu repenso e agora eu sei o quanto que era ruim pra eles e agora não quero que eles tenha mais sofrimento por conta minha não" (Michael J. Carter); "acho que se eu falar que quero mudar mesmo minha família vai me ajudar demais, ficar de boa comigo, mas vai ficar assim meio com o pé atrás; os vizinhos vão ficar assim 'será mesmo que mudou' vão ficar assim naquela..." (Andrew Gioia); "vou relacionar só com minha família mesmo, os amigos eu vou deixar de lado" (Jeremy Friedman); "bom demais; pra isso me mostrou que eu fiquei preso aqui pra refletir o que eu tava passando, o que eu tava fazendo da minha vida; quando fui de saidão mesmo eu vi isso, o que eu tava fazendo da minha vida, o povo olhou com olho cheio" (Ryan-Hwang); "minha família vai ficar muito feliz né; vai ser a mesma coisa pode falar; quando eu chegar lá vai mudar né, tipo assim, a família da gente sempre 
sente falta da gente né; é um choque muito profundo nós aqui e eles lá; pretendo ser diferente de antes" (Zak Ringelstein).

No momento da aplicação da entrevista, os adolescente foram levados a refletirem se consideravam a formação recebida na unidade suficiente para mantê-los afastados dos atos infracionais, das drogas e das más companhias. Alguns titubearam na resposta e não foram objetivos, dizendo que não achavam a formação suficiente mas que dependiam deles: "ela é suficiente para abrir minha mente mas não tenho certeza se é suficiente para me deixar longe disso tudo não, porque isso depende mais é de mim (...) da minha mentalidade mesmo" (Michael J. Carter).

Outros demostraram uma insegurança e de alguma forma transpareceram no discurso uma incerteza de como seria, apesar de acreditarem ser satisfatória a formação. A maioria se manifestou satisfatoriamente, considerando a formação recebida na unidade suficiente para (re)socializá-los: "acho, só que quando eu estiver na rua não vai ter isso né, essas ajudas que tenho aqui" (Timothy Trinidad); "no meu pensamento eu acho que sim né, tem que vê quando eu sair na rua né; hoje pra mim é” (Mattan Griffel).

Algumas falas dos adolescentes que merecem ser destacadas: "suficiente não é, mas dá para entender; o ser humano é muito esquisito; na mesma hora que está pensando nunca coisa está pensando em outra; aqui tá normal, eles fazem de tudo pra gente sair ressocializado ai” (Jason Deron); “não, pra mim foi suficiente, mas de modo geral não é não; pra mim que tô no terceiro tá mais fácil pra mim, mas tem uns ai que não quer mesmo; eles falam que não vai da conta, falta muita serie pra terminar e acaba voltando" (Andrew Gioia); "eu acho que é suficiente; aqui eles tentam tipo mostrar pra gente seguir esse caminho; se a gente abraçar, abraça; (Ryan-Hwang).

Encerrando a entrevista, numa espécie de dinâmica, foi solicitado aos adolescentes que se descrevessem no dia em que ingressaram na Unidade, para iniciaram o cumprimento da medida socioeducativa de internação e como se viam no dia em que foi feita a entrevista. Os resultados possibilitaram inferir que todos os adolescentes desenvolveram um processo de reflexão, ancorado não só no trabalho da escola mas de todos os agentes que contribuem no processo de (re)socialização. Foi possível perceber na fala de alguns o fortalecimento da autoestima desses sujeitos assim como da consciência dos seus deveres e direitos, criando ou apontando os possíveis caminhos para o seu reingresso na sociedade. 
Por acreditar que estes relatos expressam com muita sinceridade e respeito o trabalho realizado no CSEUN, serão transcritas, no Quadro 1 as falas de todos os participantes:

Quadro 1 - Relatos dos Adolescentes sobre o trabalho realizado no CSEUN, 2017.

\begin{tabular}{|c|c|}
\hline Alex Klein & $\begin{array}{l}\text { "quando eu entrava aqui eu pensava diferente, pensava em só aprontar, vender } \\
\text { drogas; hoje quero mudar de vida, encontrar uma mulher, construir uma } \\
\text { família" }\end{array}$ \\
\hline $\begin{array}{c}\text { Karim } \\
\text { Abouelnaga }\end{array}$ & $\begin{array}{l}\text { "eu era ignorante, sem cabeça, pensava sem agir; hoje penso mais nele mesmo, } \\
\text { no futuro, não pensava no futuro não" }\end{array}$ \\
\hline $\begin{array}{l}\text { Michael J. } \\
\text { Carter }\end{array}$ & $\begin{array}{l}\text { "eu era uma pessoa bastante sem ideia sem pensamento, sem projeto de vida, } \\
\text { não dava valor no que tinha, agora já penso fazer isso tudo que eu falei e da } \\
\text { valor em minha família, porque quem ta me ajudando de verdade não é meus } \\
\text { colegas que antigamente me levavam para onde eu tô hoje não, é minha família } \\
\text { que ta me ajudando. }\end{array}$ \\
\hline Jason Deroner & $\begin{array}{l}\text { "eu era bagunçado, muito indignado e tal; não ligava pra nada e ninguém; agora } \\
\text { eu já penso em tudo as coisas que eu perdi, minha família esses trem ai; sair } \\
\text { daqui, caçar um serviço, melhor ai" }\end{array}$ \\
\hline Andrew Gioia & $\begin{array}{l}\text { "nunca tinha pegado um livro pra ler, só vivia drogado, dentro de um barraco, } \\
\text { grilado com polícia entrando pra dentro, esses trem assim, inimigo, risco de } \\
\text { tomar tiro; minha mãe, eu não tava nem ai para o que ela falava, era isso mesmo } \\
\text { qualquer coisa, acho que é só isso mesmo; hoje eu respeito os outros mais, } \\
\text { tenho humildade aprendi também, tenho humildade, saber conversar com as } \\
\text { pessoas, os estudos também" }\end{array}$ \\
\hline Michael Gioia & $\begin{array}{l}\text { "eu era brincalhão demais com minha família, com meus irmãos, trabalhava, } \\
\text { não pensava entrar no crime.... Ai depois eu fui ficando mais velho e foi } \\
\text { emanando com os caras lá... hoje pretendendo mudar de vida, mudar de aspecto, } \\
\text { ter uma nova vida" }\end{array}$ \\
\hline $\begin{array}{l}\text { Jeremy } \\
\text { Friedman }\end{array}$ & $\begin{array}{l}\text { "era atentado, usava muita droga, não fica muito dento de casa; esses dias ai eu } \\
\text { fui de saidão fiquei só dentro de casa com minha tia, não usei droga, sossegado" }\end{array}$ \\
\hline Ryan-Hwang & $\begin{array}{l}\text { "baguncento, achava que ninguém mandava em mim; se falasse um trem } \\
\text { comigo eu chutava a capa, folgava com a gente; hoje suave demais, eu quero ir } \\
\text { embora; eu aprendi, foi me ajudando, apendi abaixar a cabeça, no começo você } \\
\text { pensa que está no paraíso... antes de vir pra cã você já imagina isso aqui é bom } \\
\text { demais, ai você já abusa daquilo, até você aprender a baixar, mas depois que } \\
\text { você aprende aquele ritmo ali" }\end{array}$ \\
\hline Bill Kindler & $\begin{array}{l}\text { "de quando eu cheguei aqui eu já falei no atendimento, eu não pensava em } \\
\text { mudar não, usar droga aqui dentro; tudo que tinha pra aprontar aqui dentro eu } \\
\text { aprontava; mas depois que fui de saidao, foragir, voltei, vi que não compensa, } \\
\text { desistir; hoje em dia eu penso nas coisas que eu pensava mais não; penso em ter } \\
\text { filho, casar com minha namorada, ser feliz" }\end{array}$ \\
\hline Timothy & $\begin{array}{l}\text { "quando eu cheguei aqui no início eu pensei só em maldade, sair daqui e fazer } \\
\text { uns trem ruim ai, só maldade que eu tinha, só ódio; mas agora já consegui }\end{array}$ \\
\hline
\end{tabular}




\begin{tabular}{|c|l|}
\hline Trinidad & $\begin{array}{l}\text { aliviar e tirar isso de mim; to mais de boa; penso em dar orgulho pra minha } \\
\text { família; fazer minha mãe ter orgulho de mim" }\end{array}$ \\
\hline Mattan Griffel & $\begin{array}{l}\text { "antes eu era mais... como que fala, eufórico; ficava só pensando em coisa ruim, } \\
\text { mas agora to mais tranquilo, consigo mais controlar meus pensamentos, to } \\
\text { tranquilo" }\end{array}$ \\
\hline Dan Johnston & $\begin{array}{l}\text { "de antes eu não somava assim com nada pra fazer as coisas ruins não, agora eu } \\
\text { penso antes de fazer" }\end{array}$ \\
\hline Benjamin Levy & $\begin{array}{l}\text { "mudei, já to ressocializado né; não uso droga mais, não to roubando mais, não } \\
\text { to fazendo nada, não to fazendo nada de errado; o dia que entrei aqui eu era } \\
\text { acelerado, tudo queria do meu jeito, eu vi que não é desse tipo, que não é tudo } \\
\text { do meu jeito" }\end{array}$ \\
\hline Zak Ringelstein & $\begin{array}{l}\text { "mudei muito né; era mais novo, menor, minha mente tipo evolui depois; } \\
\text { pensava só em mais revolta no começo, sair daqui em vez de melhorar voltar } \\
\text { pior; hoje to mais tranquilo, pensativo; mudei as reações, o jeito de falar" }\end{array}$ \\
\hline
\end{tabular}

Fonte: Dados da presente pesquisa.

Neste capítulo foi possível perceber, sob a perspectiva dos adolescentes privados de liberdade do CSEUN, que as práticas educacionais desenvolvidas no local são importantes para a formação dos mesmos. Os alunos valorizam o trabalho dos professores e demonstraram respeito pelas aulas. Alguns disseram ter consciência de que este trabalho requer um preparo, dedicação e tempo, como ficou evidente em algumas falas: "[...] todo dia eles levantam cedo pra vim aqui; o trabalho deles é bom" (Benjamin Levy). “[...] eles estão aqui pra ajudar nós” (Alex Klein).

Foi possível analisar como o tempo em sala de aula é significativo, e como se sentem "notáveis" e respeitados. É como se naquele espaço tivessem "voz", oportunidade de expressarem, tirarem suas dúvidas, participarem mais das aulas, o que para alguns, não acontecia na escola fora da unidade.

Ressalta-se, que não se deve atribuir nenhum valor as escolas que estes adolescentes estudaram, antes de ingressarem no CSEUN, mesmo porque estes locais não foram objeto desta pesquisa. O único dado disponível é que todos os adolescentes vieram de escolas públicas. A análise que se pode fazer vai ao encontro do que já foi expresso no referencial teórico, em que muitos adolescentes, nas condições semelhantes aos estudados nesta pesquisa, veem a escola como um local de entretenimento, apenas para "pegar as meninas", encontrar com os colegas, ter contato com outros usuários de drogas, entre outras características. Com isso, ratifica-se o que muitos levantamentos 
têm apresentado ao longo dos anos, sendo frequente em adolescentes em conflito com a lei, a evasão escolar ou a repetição de séries. (BRASIL, 2012; BRASIL, 2013).

Através das falas de cada adolescente, ficou nítido como as atividades desenvolvidas na unidade e principalmente as oficinas e dinâmicas realizadas pelas assistentes sociais, despertam neles certa introspecção. Claro que a privação de liberdade provoca automaticamente essa introspecção, pois eles têm "todo tempo disponível" para as atividades ofertadas ao longo do dia, mas ela (introspecção) seria inútil se não houvesse mediadores profissionais e competentes.

Alguns adolescentes entrevistados mencionaram, em determinado momento, sobre as dinâmicas que participam durante as atividades. Essas dinâmicas, que os professores confirmaram trabalharem, provocam reflexões sobre os projetos de vida, as atitudes e sobre as relações familiares. Lembro-me de um adolescente relatando uma dinâmica na qual uma assistente social "interpretava" o papel de sua mãe e como aquilo mexeu com ele. Acredito que em nenhum outro momento de suas vidas esses adolescentes tiveram a oportunidade ou usaram a oportunidade, para refletirem sobre seus projetos de vida, ou as consequências que suas atitudes desencadeiam em suas famílias, comunidades e sociedade em geral.

Os alunos são levados a constante reflexão na Unidade e isso é um ponto relevante desse projeto (re)socializador. São inseridos em práticas educacionais que os permitem ter conhecimento sobre temas como cidadania; meio ambiente; drogas ilícitas e seus malefícios a saúde e sociedade; sexualidade e assuntos relacionados como doenças sexualmente transmissíveis, entre outros. Além disso, confessaram que só depois de estarem na Unidade aprenderam a pensar no futuro, respeitar os outros, ter empatia com o próximo, pensar antes de tomar decisões. (Ver Quadro 01).

Outra característica que foi possível analisar, principalmente durante as entrevistas com os adolescentes do CSEUN, foi o sentimento de medo, nitidamente expresso em algumas falas, ao serem questionados sobre o momento de saírem da Unidade. Na percepção de alguns, não descartam a importância e contribuição do trabalho realizado na unidade para suas vidas. Contudo, ainda há aqueles que demostraram incertezas quanto ao futuro: “[...] quando eu estiver na rua não vai ter isso né, essas ajudas que tenho aqui" (Timothy Trinidad); [...] tem que vê quando eu sair na" (Mattan Griffel). 
Acredito que o trabalho dos professores e todos os demais profissionais do CSEUN precisam concentrar esforços para criarem estratégias que atenuem a ansiedade sofrida por alguns dos seus adolescentes. Além disso, desenvolver políticas, mesmo que em âmbito regional, que assegurem ações de assistência a todos os adolescentes egressos (psicológica, social, educacional, jurídica). Como exemplo, poderia ser criado parcerias com algumas escolas, tanto de educação básica quanto profissionalizante, empresas e demais setores da sociedade civil, para criares ações de acolhimento a estes adolescentes no momento em saírem da unidade.

Analisar a trajetória de um adolescente em conflito com a lei até o seu ingresso, coercitivo, em uma unidade de atendimento socioeducativo, não esgota os reais problemas vividos por eles. Da mesma forma que seria ingênuo dizer que o atendimento recebido pelos adolescentes do CSEUN é suficiente. Todo o sistema, em consonância com as diretrizes da Doutrina de Proteção Integral asseguradas no ECA, precisa articular estratégias que garantam o retorno do adolescente as suas reais vivências, ao seio da família e comunidade. Organismos que os acolham e os acompanhe para assegurar a eficiência do trabalho realizado.

Posto isso, é possível afirmar que as políticas e práticas educacionais desenvolvidas no CSEUN são satisfatórias e assistem aos adolescentes em conflito com a lei, que ali cumprem medida de atendimento socioeducativo (na percepção destes). Dizer que são satisfatórias não é o mesmo que dizer que são suficientes, pois acredito que o trabalho sempre requer aperfeiçoamento e qualificação. E, além disso, passa pelo discurso paradoxal da institucionalização de crianças e adolescentes, que lamentavelmente, ainda existe no Brasil. 


\section{CONSIDERAÇÕES FINAIS}

Este trabalho somente se concretizou mediante profunda determinação em conhecer de perto a realidade vivida por adolescentes, autores de atos infracionais, sujeitos a medida socioeducativa de internação, prevista no artigo 121 da Lei 8.069/90 Estatuto da Criança e do Adolescente - ECA (BRASIL, 2016). E mergulhar neste amplo universo de tantos paradoxos fez com muitos conceitos fossem descontruídos e dessem lugar a uma compreensão mais humana e sensível para com esses sujeitos.

Isso só foi possível a partir do momento em que se inverteu a lógica da análise e, aos adolescentes, foi dada voz e vez para que pudessem expor, sem nenhuma limitação ou tabu, toda a percepção que tinham sobre o sistema socioeducativo. Foi possível construir e descrever a trajetória desses sujeitos sob o olhar deles, já que são os protagonistas de todo esse complexo sistema, que se arrasta em nossa cultura há anos.

O processo de institucionalização de crianças e adolescentes no Brasil passou por diversas fases e mudanças radicais na forma de se pensar e propor políticas e ações. Um processo histórico que sustentou um discurso, até a década de 1980, de controle e exclusão social com as políticas assistencialistas e a Doutrina de Situação Irregular. Ao debruçarmos sobre a história é possível perceber que a infância e adolescência foram tratadas ao longo dos anos de múltiplas maneiras, tendo suas relações sociais estabelecidas com a família, com a Igreja, com o Estado. Estas instituições impregnaram valores culturais, religiosos, legais e morais que são reais em nossa sociedade e são reproduzidos até os dias de hoje. (PEREZ; PASSONE, 2010; RIZZINI, 2004; 2005).

O processo de redemocratização vivido no Brasil a partir da promulgação da Constituição Federal de 1988 (BRASIL, 1988) foi o ponto de partida para estabelecer um novo olhar sobre as questões pertinentes as crianças e adolescentes. Isso só foi possível graças à luta de movimentos sociais e ao caloroso apelo popular que denunciavam sobre as atrocidades e a ineficácia da prática de confinamento em instituições, destinadas a elas. Naquele contexto histórico foi engendrado uma nova política para estes sujeitos, com a chamada Doutrina de Proteção Integral e ratificado com a promulgação do ECA.

Há 27 anos em vigor, o ECA ainda não alcançou todos os efeitos propostos em seus princípios e objetivos. Apesar de significativos avanços no trato com crianças e, 
especificamente com adolescentes em cumprimento de medidas socioeducativas, ainda há instrumentos de resistência às mudanças e inercia por parte dos gestores, articuladores e executores das políticas de modo geral.

O quadro geral sobre a realidade das instituições que cuidam de adolescentes em conflito com a lei ainda é grave e os últimos levantamentos do Sistema Nacional de Atendimento Socioeducativo - Sinase tem mostrado um crescimento no número de adolescentes e jovens em cumprimento de medidas socioeducativas de internação, internação provisória e semiliberdade. Os dados mostram que no ano de 2011 esses adolescentes correspondiam a 19.595, em 2012 eram 20.532, em 2013 o número saltou para 23.066, no ano de 2014 chegou a 24.628 adolescentes e no ano de 2015 (último levantamento) o total de adolescentes e jovens, nessas medidas socioeducativas chegou a 26.209. (BRASIL, 2018).

É preciso discutir toda a problemática em torno do adolescente em conflito com a lei, que até hoje o poder público e ECA não foram capazes de sanar os fatores de vulnerabilidade - individual, relacional, comunitário e social (KRUG, 2002; BRASIL, 2005). Os dados ratificam o que a história vem mostrando ao longo dos anos, sendo os mais vulneráveis aqueles adolescentes do sexo masculino, que pertencem a famílias pobres, que vivem em áreas periféricas dos centros urbanos e de cor preta e parda. Há uma reprodução sistemática que as políticas ainda não romperam.

O último levantamento Sinase ratifica o exposto ao mostrar a distribuição dos/das adolescentes e jovens no Sistema Socioeducativo com relação à questão de gênero, com a predominância de adolescentes do sexo masculino (96\%). No que tange à faixa etária dos adolescentes/jovens em restrição e privação de liberdade, os dados mostram que a maior proporção dos adolescentes está concentrada na faixa etária entre 16 e 17 anos com 57\% (15.427), seguida pela faixa etária de 18 a 21 anos com 23\%, entre 14 a 15 anos com $17 \%$ e 12 a 13 anos com 2\%, havendo, ainda, $1 \%$ sem especificação de faixa etária. As informações coletadas sobre raça/cor revelaram que $61,03 \%$ dos adolescentes e jovens em restrição e privação de liberdade foram considerados de cor parda/preta, $23,17 \%$ de cor branca, $0,81 \%$ de cor amarela e $0,28 \%$ da raça indígena. E mais, $14,67 \%$ dos adolescentes e jovens não tiveram registro quanto à sua cor ou raça, sendo classificados na categoria sem informação. (BRASIL, 2018).

Os Levantamentos têm mostrado que ainda hoje, os crimes contra o patrimônio registram maiores números na distribuição total de atos infracionais. No ano de 2015 , 
$46 \%$ (12.724) do total de atos infracionais foram classificados como análogo a roubo (acrescido de 1\% de tentativa de roubo), e 24\% (6.666) foram registrados como análogo ao tráfico de drogas. O ato infracional análogo ao homicídio foi registrado em $10 \%$ (2.788) do total de atos praticados, acrescido de $3 \%$ de tentativa de homicídio (BRASIL, 2018).

Ainda hoje é comum em nossa cultura se referir a um adolescente em conflito com a lei com termos pejorativos e impregnados de preconceitos como 'delinquente', 'de menor', 'trombadinha', 'menor infrator', entre outros. Isso só corrobora o discurso da repressão e exclusão que se estende a cada ano.

Os movimentos sociais que tanto lutaram pela materialização da Doutrina de Proteção Integral e idealizaram uma legislação específica que fosse eficiente (não que o ECA não seja) ainda enfrentam acirrados embates. Entre esses debates estão aqueles contra os defensores dos projetos legislativos que defendem a redução da maioridade penal; as rebeliões que acontecem em unidades de internação; a precariedade na assistência à educação e saúde em algumas unidades bem como a fragilidade de algumas instituições em implantar, e, até mesmo, compreender, o que de fato seja o projeto (re)socializador. (GONÇALVES, 2005).

É evidente que a responsabilidade do cenário atual não é do ECA mas, no meu entendimento, ele é coparticipe a partir do momento em que ainda perpetua um modelo tutelar-repressivo, frágil na aplicabilidade das políticas e práticas de (re)socialização. $\mathrm{O}$ Estado é co-autor a partir do momento em que se torna negligente diante da necessidade de se aplicar políticas e ações de prevenção para atender a crianças e adolescentes em situação de risco e vulneráveis ao ato infracional.

A institucionalização de crianças e adolescentes é um fator que urge ser repensado no país, pois caminhamos para um colapso generalizado no que tange aos direitos e garantias desses sujeitos em conflito com a lei. Nas palavras de Baratta (2007, p.2) a "melhor prisão é, sem dúvida, a que não existe". Apesar do ECA trazer explicito em seu texto que a internação é apenas em casos excepcionais, nota-se que o temor social, alimentado, muitas vezes, pela imprensa sensacionalista, com discursos de insegurança e impunidade, leva a população a um discurso ferrenho, inflamado e despido de qualquer conhecimento científico, que prega a redução da maioridade penal e que esse adolescente "deve" ter restrita a sua liberdade. 
O discurso é vazio e fragilizado, por parte dos seus defensores, pois se eximem de qualquer responsabilidade. $\mathrm{O}$ discurso é paradoxal, pois não se pode compreender uma sociedade que luta por liberdade, justiça e solidariedade, ao mesmo tempo, em que segrega seus próprios adolescentes, ao invés de proporcionar a eles mais educação, saúde, lazer, esporte, entre outras assistências.

Todo esse cenário problemático onde atua os adolescentes em conflito com a lei e o sistema socioeducativo, de acordo com Passeti et al (1999, p. 126)

[...] Faz com que o pensamento político permaneça circunscrito às discussões em torno de "por que a violência", adiando novamente a discussão "por que não a paz", se afinal entendemos com ECA a partir dos seus [...] indicadores pedagógicos educacionais, terapêuticos e compensatórios

Sendo assim, a justificativa para a realização da presente pesquisa teve como respaldo a importância de se compreender qual a influência que as práticas e as políticas educacionais exercem em adolescentes, atores de Atos Infracionais, sujeitos a medida socioeducativa de internação, para se (re)pensar o que foi feito até aqui, o que está sendo feito e o que é possível ser feito.

O problema inicialmente proposto partiu da seguinte indagação: as práticas Educacionais, bem como as diretrizes das políticas educacionais contribuem de fato no processo de formação e (re)socialização do adolescentes, em restrição de liberdade, no CSEUN? Os resultados, com ressalvas, apontaram que sim. Os adolescentes sinalizam que as atividades desenvolvidas em sala de aula, nas dinâmicas, nos projetos, com os professores e demais profissionais, contribuem para a sua formação e (re)socialização. Percebem que ali há uma oportunidade de estabelecerem novos projetos de vida, tendo acesso a conhecimentos e informações necessários para isso. São capazes de refletir sobre os seus atos, sua trajetória de vida e o significado daquele lugar. Contudo, os resultados (nas falas dos adolescentes) deixaram brechas sobre o que pensam ao saírem da unidade.

É preciso reforçar o trabalho de resgate da autoestima desses adolescentes e encorajá-los quando deixarem a unidade. Acredito que um dos caminhos para isso seja a realização de programas que incluam a participação das famílias dos adolescentes e da comunidade no local. É importante a presença de conselhos de comunidade que integrem a unidade com a sociedade. As saídas temporárias, conhecidas popularmente como "saidão", na qual o adolescente recebe em decorrência de bom comportamento ou 
outra recompensa não pode ser o único mecanismo que os vincule ao "mundo externo". Caso seja, podem ser interpretadas como barganha e não como um benefício que visa a (re)socialização.

Outro provável caminho para o resgate da autoestima e autonomia de adolescente em conflito com a lei é destinar investimentos de políticas públicas que valorizem mais as medidas socioeducativa em meio aberto (advertência, obrigação de reparar o dano, prestação de serviço à comunidade e liberdade assistida). Assim, seria mais acessível a realização de um trabalho individualizado e um projeto pedagógico voltado para a realidade de cada adolescente, rompendo com tendência de internação e mantendo a convivência familiar e comunitária.

É importante destacar também a necessidade de fortalecer o trabalho dos profissionais que atuam diretamente com esses adolescentes, principalmente os professores, os quais são agentes operadores no processo de formação. Essa valorização pode ser feita via de melhores condições de trabalho e de capacitação profissional que lhes assegure a compreensão das principais questões ligadas à Educação desses sujeitos.

Os procedimentos metodológicos foram suficientes para a conclusão deste trabalho. Optou-se pela aplicação de questionário aos professores e aos alunos. Ao aplicar o questionário aos professores foi possível compreender o perfil deste profissional, a maneira como trabalham com os adolescentes e se há neste trabalho alguma diferença quanto ao exercido em outra escola, fora daquela unidade. Alguns dados relevantes foram levantados, entre eles: a formação, especialização, experiência de trabalho com esses sujeitos, a maneira como planejam as aulas, se trabalham temas transversais, quais seriam esses temas e como avaliavam a influência do trabalho na vida dos adolescentes. Os professores desempenham um papel fundamental em todo o projeto, pois estão ligados diretamente aos adolescentes, tornando até mesmo uma referência para estes. Os professores estão na "linha de frente". Além das disciplinas básicas que lecionam, exercem uma influência direta na construção de valores, saberes e projetos de vida de casa adolescente. Os professores também são vistos como um "elo" entre os adolescentes e o "mundo exterior", pois reportam os acontecimentos fora da unidade. Este contato estabelece uma relação de confiança, que ficou muito evidente na unidade, o que com certeza é um fator positivo.

Ao aplicar o questionário aos adolescentes, buscou-se conhecê-los melhor, com perguntas que foram pertinentes a compreensão do seus dados básicos e do perfil social, 
econômico e, principalmente, educacional. O intuito foi comparar esses dados com os levantamentos anuais publicados pelo Sinase, que divulgam os dados coletados de todo o país. Os resultados foram semelhantes e ratificaram o que os estudos vêm apontando ao caracterizarem o adolescente em conflito com a lei no Brasil: a maioria é pobre, oriundo de áreas periféricas e altamente vulneráveis a criminalidade, pretos, com registro de evasão escolar e o ato infracional análogo a furto e roubo (contra o patrimônio) com maior registro.

A entrevista semiestruturada, instrumento metodológico utilizado apenas com os alunos, foi primordial e atendeu satisfatoriamente o objetivo geral desta pesquisa que foi analisar, sob a percepção dos adolescentes em restrição de liberdade, o processo de formação e (re)socialização desenvolvido no CSEUN. Primeiro a dinâmica da entrevista contribuiu: o adolescente se dirigiu a uma sala onde se posicionou de frente ao entrevistador, sem a presença de outros colegas ou de agentes socioeducativos. Segundo: cada adolescente teve a oportunidade de se expressar, fazer seus apontamentos e manifestar toda e qualquer percepção que tenham sobre o sistema socioeducativo. É incoerente o uso do termo "oportunidade" em ambientes de privação de liberdade, e é por isso, que atribuo à relevância da entrevista e a maneira que ela foi aplicada.

Assim, as palavras finais deste trabalho ratificam o que foi exposto ainda na epígrafe, quando Fiori (1992, p. 52) diz que a "prática da liberdade só encontrará adequada expressão numa pedagogia em que o oprimido tenha condições de, reflexivamente, descobrir-se e conquistar-se como sujeito de sua própria destinação histórica". Esta frase ilustra com muita propriedade a conclusão final que se faz nesta pesquisa, ao afirmar que o trabalho desenvolvido no CSEUN é satisfatório no processo de formação e (re)socialização dos adolescentes ali internados. Satisfatório, não suficiente.

As políticas públicas e as práticas educacionais precisam ser reposicionadas e pensadas não "a partir" da unidade de internação, mas "apesar dela". Os adolescentes precisam ser vistos não como objetos de intervenção, mas como sujeitos de direto, capazes de se inserirem na proposta pedagógica. Pensar que o adolescente está ali, mas não pertence aquele lugar, pois ele é autônomo quanto a sua destinação histórica e precisa novamente ter um espaço na sociedade, a fim de estabelecer relações "saudáveis" com sua família e comunidade. Além disso, é preciso garantir 
oportunidades de acesso aos mecanismos que lhe proporcionem executar os seus projetos de vida e que valha o tempo em que esteve no sistema socioeducativo. 


\section{REFERÊNCIAS}

ABERASTURY, Arminda. e cols. Adolescência. Porto Alegre: Artes Médicas, 1990.

ABERASTURY, Arminda.; KNOBEL, Mauricio. La Adolescencia Normal. Buenos Aires: Paidós, 1971.

ABRAMOVAY, M. Juventude, violência e vulnerabilidade social na América Latina: desafios para políticas públicas. Brasilia: UNESCO/BID. 2002.

ADORNO, S. A prisão sob a ótica de seus protagonistas. Itinerário de uma pesquisa. Tempo Social: Revista de Sociologia da USP, São Paulo, v.3, n. 1/2, p.7-40, 1991.

ALVES-MAZZOTTI, Alda Judith. Impactos da pesquisa educacional sobre as práticas escolares. (In) Nadi Zago, Marilia Pinto de Carvalho, Rita Almeida Teixeira Vilela (orgs.). Itinerários de pesquisa: perspectivas qualitativas em sociologia da educação. Rio de Janeiro: DP\&A, 2003.

ANDRADE, Carla Coelho de. JUNIOR, Almir de Oliveira. BRAGA, Alessandro de Almeida. JAKOB, André Caldo. ARAUJO, Tatiana Dara. O desafio da reitegração social do preso: uma pesquisa em estabelecimentos prisionais. Revista de estudos em direito. Vol. 2, n. 2, jan 2015, p. 10-30.

ARAUJO, Stephane Silva; LEITE, Maria Cecilia. A assistência educacional no sistema penitenciário federal. Revista Eletronica de Educação, v.7, n. 1, maio. São Carlos, 2013.

ARGOLO, Francisco Sales de. Redução da maioridade penal: uma maquiagem nas causas da violência. Revista Jus Navigandi, ISSN 1518-4862, Teresina, ano 12, n. 1427, 29 maio 2007. Disponível em: <https://jus.com.br/artigos/9943>. Acesso em: 2 fev. 2018.

ASSIS, Simone Gonçalves de; DESLANDES, Suely Ferreira; SANTOS, Nilton César dos. Violência na Adolescência - sementes e frutos de uma sociedade desigual. In: Impacto da Violência na Saúde dos brasileiros. Brasília: Ministério da Saúde, 2005. P. 79-116.

BANDEIRA, Marcos Antonio Santos. Atos infracionais e medidas socioeducativas: uma leitura dogmática, critica e constitucional. Ilhéus: Editus, 2006.

BARATTA, Alessandro. Criminologia crítica e crítica do direito penal. 2 ed. Rio de Janeiro: Freitas Bastos, 1999.

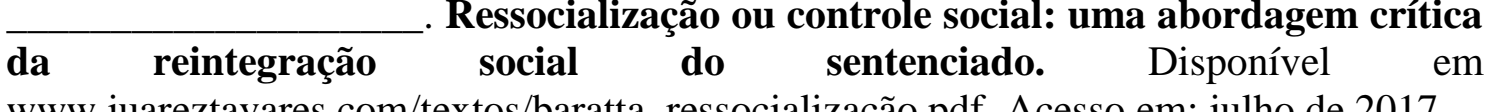
www.juareztavares.com/textos/baratta_ressocialização.pdf. Acesso em: julho de 2017.

BARROSO FILHO, José. Do ato infracional. Disponível em <www.neofito.com.br/artigos>. Acesso em: dezembro de 2017. 
BERGALLI, Roberto et al. Seção IV: Da prestação de serviços à comunidade. In: CURY, Munir (Coord.). Estatuto da Criança e do Adolescente Comentado: Comentários jurídicos e sociais. 12. ed. São Paulo: Malheiros, 2013, p. 589-592

BERGER, Peter L.; LUCKMANN, Thomas. A sociedade como realidade. A construção social da realidade tratado de sociologia do conhecimento. Petrópolis, Editora Vozes, 1973.

BOGDAN, Robert C.; BIKLEN, Sari Knopp. Investigação qualitativa em educação: uma introdução à teoria e aos métodos. Porto Editora Ldta. 1992.

BRASIL. Estatuto da criança e do adolescente (1990). [recurso eletrônico] : Lei n. 8.069, de 13 de julho de 1990, e legislação correlata. - 14. ed. - Brasília : Câmara dos Deputados, Edições Câmara, 2016. - (Série legislação ; n. 237)

Presidência da República. Secretaria de Direitos Humanos (SDH). Plano Nacional de Atendimento Socioeducativo: Diretrizes e eixos operativos para o SINASE. Brasília: Secretaria de Direitos Humanos da Presidência da República, 2013. $39 \mathrm{p}$.

Levantamento Anual SINASE 2013. Brasília: Secretaria dos Direitos Humanos da Presidência da República, 2015.

. Levantamento Anual SINASE 2014. Brasília: Secretaria Nacional dos ireitos da Criança e do Adolescente do Ministério dos Direitos Humanos, 2017

Levantamento Anual SINASE 2015. Brasília: Secretaria Nacional dos ireitos da Criança e do Adolescente do Ministério dos Direitos Humanos, 2018

Constituição (1988). Constituição da República Federativa do Brasil. Brasília, DF: Senado Federal: Centro Gráfico, 1988. 292 p.

- Código Penal. Decreto-lei n. 2.848, de 7 de dezembro de 1940. Organização do texto: Anne Joyce Angher. 7. Ed. São Paulo: Rideel, 2008.

Ministério da Educação e Cultura. Parecer CNE/CEB No 2/2010. Diretrizes Nacionais para a oferta de educação de jovens e adultos em situação de privação de liberdade nos estabelecimentos penais. In: Portal do MEC: Diretrizes para a Educação Básica. Brasília, DF, 2010. Disponível em: $<$ http://portal.mec.gov.br/index.php?option=com_docman\&task=doc_download\&gid=5 $142 \&$ Itemid=>. Acesso em: 15 de Outubro de 2015.

. Lei de Execução Penal. Lei nº 7.210 de 11 de julho de 1984.

Lei 9.982 de 14 de julho de 2000.

Código de Menores. Lei 6.697 de 10 de outubro de 1979. Revogada. 
Parâmetros de Gestão, Metodológicos e Curriculares. Escola Nacional de socioeducação. Secretaria de Direitos Humano. Brasília, 2014.

BRUNO, A. Educação formal, não formal e informal: da trilogia aos cruzamentos, dos hibridismos a outros contributos. Mediações, Revista OnLine da Escola Superior de Educação do Instituto Politécnico de Setúbal, 2 (2), 10-25. 2014.

CALIMAN, Geraldo. Fundamentos teóricos e metodológicos da pedagogia social na Europa (Itália). In Proceedings of the 1. I Congresso Internacional de Pedagogia Social, 2006, São Paulo (SP) [online]. Disponível em: $<$ http://www.proceedings.scielo.br/scielo.php?script=sci_arttext\&pid=MSC0000000092 006000100015\&lng=en\&nrm=iso>. Acesso em 04 de setembro de 2017.

CAMPOS, Pedro Humberto Faria; Campos, Denise Teles Freire. Banalização da violência e negação do sujeito na adolescência. In: SOUSA, Sonia Maria Gomes. Adolescentes autores de ato infracionais: estudos psicossociais. Goiânia: Editora da PUC Goiás, 2013.

CAMPOS, Fernando Soares. Adolescentes infratores acautelados: uma caricatura dos sistemas penitenciários. In: ZAMORA, Maria Helena. Para Além das grades. Rio de Janeiro. Ed. PUC-Rio, 2005.

CASTRO, A. S.; Guareschi, P. (2007, October 30). Adolescentes autores de atos infracionais: processos de exclusão e formas de subjetivação. Revista Psicologia Política [Online], $7(13)$.

Disponível: http://www.fafich.ufmg.br/ psicopol/seer/ojs/viewarticle.php?id=28.

Acesso em: dezembro de 2017.

CAUREL, Ana Lúcia. Representação social da escola para o adolescente infrator. Dissertação de Mestrado em Educação. Universidade Estadual Paulista Júlio de Mesquita Filho/Marília, 2003.

CAVALCANTE, Claudia Valente. A importância da sociologia da infância e as práticas pedagógicas: a criança como sujeito histórico e de direitos. In: Cadernos de artigos: infâncias, adolescências, juventudes e famílias: desafios contemporâneos. Goiânia: Gráfica e Editora América, 2014

CHARLOT, Bernard. A pesquisa educacional entre conhecimentos, políticas e práticas: especificidades e desafios de uma área de saber. Revista Brasileira de Educação. V.11, n. 31, jan./abr.2006.

CNJ - Conselho Nacional de Justiça. Panorama Nacional A Execução das Medidas Socioeducativas de Internação. Programa Justiça ao Jovem. 2012.

COSTA, Lorena Xavier da. Sujeito de direito e pessoa: conceitos de igualdade? In.: Legis August. Rio de Janeiro: v. 4, n. 2, p. 75-87, jul./dez. 2013.

CUNHA, José Ricardo. Visualizando a política de atendimento à criança e ao adolescente. Rio de Janeiro. Litteris Ed., KroArt, Fundação Bento Rubião, 1998. 
DAVID, Pedro R. Sociologia Criminal. 6. Ed.. Bueno Aires: Depalma, 2003.

DE ARGOLO, Francisco Sales. Redução da maioridade penal: uma maquiagem nas causas da violência. Cidade: Editora, 2007.

DESLANDES, S. F.; ASSIS, S. G.; SANTOS, N. C. Violência envolvendo crianças no Brasil: um plural estruturado e estruturante. In: BRASIL, Ministério da Saúde. Impacto sobre a violência na saúde dos brasileiros. Brasília: Ministério da Saúde, 2005.

DIAS, Aline Fávaro; ONOFRE, Elenice Maria Cammarosano. O significado da escola para jovens autores de ato infracional. In: JULIÃO, Elionaldo Fernandes. Educação para jovens e adultos em situação de restrição e privação de liberdade: questões, avanços e perspectivas. Paco Editorial: 2013. P. 243-263.

DÍAZ, André Soriano. Uma aproximação à Pedagogia - Educação Social. In: Revista Lusófona de Educação, 2006, 7, p. 91-104. Disponível em: www.scielo.com.br.

DUARTE, Alisson José Oliveira. Celas de aula: o exercício da professoralidade nos presídios. Revista Encontro de pesquisa em educação. Uberaba, v.1, n.1, p. 25-36, 2013.

DUBET, François. A sociologia da experiência. Lisboa, Instituto Piaget. 1996.

DURKHEIM. E. Educação e Sociologia. São Paulo, Melhoramentos, 1978.

DUTRA, Carlos Augusto de Amorim. A inimputabilidade penal e as medidas aplicáveis aos jovens infratores no Brasil e na Argentina. (Dissertação). Curso de Mestrado em Relações Internacionais para o Mercosul, da Universidade do Sul de Santa Catarina. Florianópolis, 2006.

ELIAS, Roberto João. Direitos Fundamentais da Criança e do Adolescente. São Paulo: Saraiva, 2005.

FALEIROS, Vicente de Paula. Infância e processo político no Brasil. In: PILOTTI, F.; RIZZINI,I. (Org.). A arte de governar crianças: a história das políticas sociais, da legislação e da assistência à infância no Brasil. São Paulo: Cortez, 2011.

FERNANDES. A. F. Integração de alunos com Necessidades Educativas Especiais no Ensino Regular - Estudo de caso Escola Secundária Amor de Deus. 2011. Dissertação (Mestrado em Educação Especial). Universidade de Cabo Verde. Escola Superior de Educação de Lisboa, Praia, 2011.

FERNANDES, Cleoni. À procura da senha da vida-de-senha a aula dialógica. In: VEIGA, Ilma Passos Alencastro (Org.). Aula: gênese, dimensões, princípios e práticas. Campinas: Papirus, 2008. p.145-165

FERRANDIN, Mauro. Ato penal juvenil: aplicabilidade dos princípios e garantias do ato penal. Curitiba: Juruá, 2009.

FIORI, Ernani Maria. Educação e Política. Ed. E\&PM, Porto Alegre, 1992. 
FOUCAULT, Michel. Vigiar e Punir: nascimento da prisão. Tradução de Raquel Ramalhete. 35. Ed. Petrópolis, RJ: Vozes, 2008.

FREIRE, Paulo. Pedagogia da autonomia: saberes necessários à prática educativa. 8 . ed. São Paulo: Paz e Terra, 1998.

FREIRE, P. Educação como pratica de liberdade. Rio de Janeiro: Paz e Terra, 1983.

Política e Educação: ensaios. 5. ed. São Paulo: Editora Cortez, 1993. Col. Questões de nossa época.

FREITAS, Marcos Cezar de; BICCAS, Maurilane de Souza. História social da educação no Brasil (1926-1996). São Paulo: Cortez Editora, 2009.

GADOTTI, M. Educação Popular, Educação social, Educação Comunitária: conceitos e práticas diversas, cimentadas por uma causa comum. Revista Diálogos: pesquisa em extensão universitária. IV Congresso Internacional de Pedagogia Social: domínio epistemológico, 2012.

GATTI, Bernardete Angelina. A construção da pesquisa em educação no Brasil. Brasília: Liber Livro Editora, 2007. 87p.

GENTILI, P.A.A. O discurso da "qualidade" como nova retórica conservadora no campo educacional. In: GENTILI, P.A.A.; SILVA, T.T. Neoliberalismo, qualidade total e educação. Petrópolis: Vozes, 1995.

GIL, Antônio Carlos. Como elaborar projetos de pesquisa. - 4. ed. - São Paulo: Atlas, 2002.

GOHN, Maria da Glória. Educação não formal e o educador social: atuação no desenvolvimento de projetos sociais. São Paulo: Cortez, 2010.

GONDRA, José Gonçalves; SCHUELER, Alessandra. Educação, poder e sociedade no império brasileiro. São Paulo: Cortez Editora, 2008.

GONZÁLEZ REY, Fernando. Pesquisa qualitativa e subjetividade: os processos de construção da informação. São Paulo: Cengage Learning, 2015.

GUARÁ, I. Abrigo - comunidade de acolhida e socioeducação. In M. Baptista \& I. R. Guará (Orgs), Abrigo: comunidade de acolhida e socioeducação. São Paulo: Instituto Camargo Corrêa e NECA. 2010.

GRACIANO, Mariângela. A educação nas prisões: um estudo sobre a participação da sociedade civil. [doi:10.11606/T.48.2010.tde-28012011-140835]. São Paulo: Faculdade de Educação, Universidade de São Paulo, 2010. Tese de Doutorado em Educação. Acesso em: dezembro de 2017.

HADDAD, Sérgio. Os Desafios da Educação Escolar e não Escolar nas Prisões. In: YAMAMOTO, Aline et al. CEREJA Discute: educação em prisões. São Paulo: Alfasol: CEREJA, 2010. P. 119-122. 
JULIÃO, Elionaldo Fernandes. As políticas de educação para o sistema penitenciário. Análise de uma experiência brasileira. In: ONOFRE, Elenice Maria Camarosano (org.). Educação escolar entre grades. Edufscar, São Paulo, 2007.

JULIÃO, Elionaldo Fernandes. Educação para jovens e adultos em situação de restrição e privação de liberdade: questões, avanços e perspectivas. Jundiaí, Paco Editorial: 2013

KATHIE, N. Impactos da violência na saúde. São Paulo: Editora Fiocruz, 2009.

KRUG, E. G. et al. (Org.). Relatório mundial sobre violência e saúde. Geneva: Organização Mundial da Saúde, 2002.

LAHIRE, Bernard. L'homme pluriel. Paris, Nathan, 1998.

2002.

Homem plural: os determinantes da ação. Petrópolis, Vozes,

LAMENZA, Francismar. Os direitos da criança e do adolescente e a discricionariedade do Estado. Barueri, SP: Minha Editora, 2011.

LEVISKY, David Leo. Adolescência: reflexões psicanalíticas. São Paulo: Casa do Psicólogo, 1998.

LEVISKY, David Leo. Adolescência e Violência: consequências da realidade brasileira. São Paulo: Casa do Psicólogo, 2000.

LUDKE, Menga; ANDRE, Marli E. D. A. Pesquisa em educação: abordagens qualitativas. São Paulo: EPU, 1986.

MACHADO, Martha Toledo. A proteção constitucional da criança e adolescentes e os direitos humanos. Barueri - SP: Manoele, 2003.

MACHADO, Evelcy Monteiro. A Pedagogia Social: diálogos e fronteiras com a educação não-formal e educação sócio comunitária. UNISAL, 2014.

MANZINI, Eduardo José. Considerações sobre a elaboração de roteiro para entrevista semi-estruturada. In: Maria Cristina Marquezine, Maria Amélia Almeida, Sadao Omote (orgs.) Colóquios sobre pesquisa em educação especial. Londrina: Eduel, 2003. P. 1125 .

MIRABETE, Júlio Fabrini. Execução Penal. 10. ed. São Paulo: Atlas, 2002, p. 83

NAVES, Rubens; GAZONI, Carolina. Direito ao futuro: desafios para a efetivação dos direitos das crianças e dos adolescentes. São Paulo: Imprensa Oficial do Estado de São Paulo, 2010.

NEVES, Libéria. Pedagogia Social e psicologia: diálogos possíveis na educação não formal. In: Paidéia: revista do curso de pedagogia da Faculdade de Ciências Humanas e 
Sociais. Universidade Fumec - Ano 5, número 5 (jul. dez. 2008) - Belo Horizonte: Universidade Fumec. Faculdade de Ciências Humanas, p.101-118.

NOGUEIRA, Cláudio Marques Martins. A abordagem de Bernard Lahire e suas contribuições para a sociologia da educação. $36^{a}$ Reunião Nacional da ANPEd - 29 de setembro a 02 de outubro de 2013, Goiânia-GO.

NÓVOA, A. (Org). Profissão Professor. Porto: Ed. Porto, 1995.

OLIVEIRA, Djaci David de. Redução da Maioridade Penal: mais segurança ou mais violência?. In.: Jornal UFG. Ano IX, nº 73, junho de 2015.

OLIVEIRA, Giovane Rodrigues de. Perfil socioeconômico dos autores de atos infracionais na cidade de Montes Claros. Dissertação de Mestrado apresentada ao Programa de Pós-Graduação em Desenvolvimento Social da Universidade Estadual de Montes Claros como requisito à obtenção do título de Mestre. Montes Claros-MG. 2010.

OLIVEIRA, Carolina Bessa Ferreira de. A educação escolar no contexto prisional à luz das representações dos presos: um estudo de caso da penitenciária de Uberlândia/mg. Disponível em < http://www.proceedings.scielo.br $>$. Acesso em: dezembro de 2017.

ONOFRE, Elenice Maria C. Educação escolar entre as grades. São Carlos: 2007.

A escola da prisão como espaço de dupla inclusão:

no contexto e para além das grades. Polyphonía, São Paulo: Polyphonia, 2011.

ORTEGA, J. Educación social especializada. Barcelona: Ariel, 1999.

OTIOBONI, M. Educação escolar entre as grades. São Carlos: 2007.

PAES, P. O socioeducador. In P. Paes, S. Amorim \& Pedrossina (Orgs.), Formação continuada de socioeducadores. Campo Grande: Programa Escola de Conselhos. 2008.

PASSETI, E.; et. al. (org.).Violentados: crianças, adolescentes e justiça. São Paulo: Imaginário, 1999.

PEDRON, Luciana da Silva. Entre o coercitivo e o educativo: uma análise da responsabilização socioeducativa na internação de jovens em conflito com a lei. UFMG/FaE, 2012. $110 \mathrm{f}$.

PEREIRA, Anete Marilia. Cidade Média e Região: o significado de Montes Claros no norte de Minas Gerais. Tese de doutorado apresentada ao Programa de Pósgraduação em Geografia da Universidade Federal de Uberlândia, como requisito parcial à obtenção do título de doutor em geografia. Uberlândia - MG, 2007.

PEREIRA, Tania da Silva. A convenção e o estatuto: um ideal comum de proteção ao ser humano em vias de desenvolvimento. In: PEREIRA, T.S. (Coord.). Estatuto da 
Criança e do Adolescente. Lei 8.069/90: estudos sociojurídicos. Rio de Janeiro: Renovar, 1992.

PEREZ, José Roberto Rus; PASSONE, Eric Ferdinando. Políticas Sociais de Atendimento às crianças e aos adolescentes no Brasil. In. Cadernos de Pesquisa. V. 40, n. 140, p. 649-673, maio/ago. 2010.

PETERS, B. G. American Public Policy. Chatham, N.J.: Chatham House. 1986.

PIAGET, Jean. A equilibração das estruturas cognitivas: problema central do desenvolvimento. Rio de Janeiro: Zahar, 1976.

PIAGET, Jean. Gêneses das estruturas lógicas elementares. Rio de Janeiro: Zahar, 1971a.

PIAGET, Jean. Los estádios del desarrollo del niño e del adolescentes. In:WALLON, Henri et al. Los estádios em la psicologia del niño. Bueno Aires: Nueva Visión, $1971 b$.

PINTO, P. SILVA, R. Socioeducação: que prática é essa? In I. L. Paiva, C. Souza \& D. B. Rodrigues (Orgs), Justiça juvenil: teoria e prática no sistema socioeducativo. Natal: Editora da UFRN. 2014.

PINHEIRO, Veralúcia. A educação e os jovens em conflito com a lei. In: SOUSA, Sônia Maria Gomes. Adolescentes autores de atos infracionais: estudos psicossociais. Goiânia: Ed. Da PUC Goiás, 2013.

PIOVESAN, Flávia. Direitos Humanos e o Trabalho. Revista da AMATRA II, São Paulo, 2003.

RAMIDOFF, Mario Luiz. SINASE - Sistema Nacional de Atendimento Socioeducativo. Comentários à Lei n. 12.594, de 18 de janeiro de 2012. São Paulo: Saraiva, 2012.

REALE, Miguel. Lições Preliminares de Direito. 19. ed. São Paulo: Saraiva, 1991.

RIBEIRO, M. Exclusão e educação social: conceitos em superfície e fundo. Educ. Soc., 27 (94), 155-178. 2006.

RIZZINI, Irene. Acolhendo crianças e adolescentes: experiências de promoção de direito à convivência familiar e comunitária no Brasil. 2. ed. São Paulo; Brasília: Cortez; UNICEF, 2007.

RIZZINI, Irene; RIZZINI, Irma. A institucionalização de crianças no Brasil: percurso histórico e desafios do presente. Rio de Janeiro: Editora PUC-Rio; São Paulo: Loyola, 2004.

RIZZINI, Irene. PILOTTI, Francisco. A arte de governar crianças: a história das políticas sócias, da legislação e da assistência à infância no Brasil. São Paulo: Cortez, 2011. 
RIZZINI, Irma. O surgimento das instituições especializadas na internação de menores delinquentes. In: ZAMORA, Maria Helena (Org.). Para além das grades: elementos para a transformação do sistema socioeducativo. Rio de Janeiro: Editora PUC-Rio; São Paulo: Loyola, 2005.

RIZZINI, Irene. Estatuto da criança e do adolescente. Considerações sobre sua implementação. In Violência e Direitos. Revista O Social em Questão, volume 6Número 6 - 2001. Rio de Janeiro: PUC, Departamento de Serviço Social.

ROCHA, Enid. A trajetória da política da criança e do adolescente no Brasil. In.: Relatório Avaliativo: ECA 25 anos. Brasília, 2016.

ROUSSEAU, Jean-Jacques. Emilio ou da Educação. São Paulo: Martins Fontes, 1985.

SANCHES, I., TEODORO, A. Da integração à inclusão escolar: cruzando perspectivas e conceitos. Revista Lusófona de Educação, América do Norte, 8, Jul. 2009. Disponível em <revistas.ulusofona.pt/index.php/rleducacao/article/view/691>. Acesso em: 15 Jul. 2016.

SANTOS, S. A. A educação escolar no sistema prisional sob a ótica dos detentos. 2002. Dissertação (Mestrado em Educação) - Pontifícia Universidade Católica de São Paulo, São Paulo.

SCARANO, Julita. Crianças esquecidas das Minas Gerais. In: História das crianças no Brasil. Mary Del Priore organizadora. 6 ed., $2^{\mathrm{a}}$ reimpressão. - São Paulo: Contexto, 2009.

SCHERMAN, L. W. et al. Prevention crime: what works, what doesn't, what's promising: areport to the United States Congress. Washington: National Institute of Justice, 1997.

SETTON, Maria da Graça Jacintho. A particularidade do processo de socialização contemporâneo. Tempo Social, revista de sociologia da USP, v.17, n.2, 2005.

SETTON, Maria da Graça Jacintho. Teorias da socialização: um estudo sobre as relações entre indivíduo e sociedade. Educação e Pesquisa, São Paulo, v. 37, n. 4, p. 711-724, dez. 2011.

SILVA, Marco Junio Gonçalves da. Tratados Internacionais de Proteção InfantoJuvenil. In: Âmbito Jurídico, Rio Grande, XV, n. 106, Nov de 2012. Disponível em <www.ambito-juridico.com.br〉. Acesso em: 10 de julho de 2017.

SILVA, Cláudio Augusto Vieira da (coord.). Sistema Nacional de Atendimento Socioeducativo: marcos normativos nacionais e internacionais. Brasília: Universidade de Brasília, CEAG, 2016. 340p.

SIQUEIRA JUNIOR, Paulo Hamilton. Função dos princípios constitucionais. Revista do Instituto dos Advogados de São Paulo, São Paulo, v.7, n.13, p.157-166, jan./jun. 2004. 
SORALI, Ubaldino Calveto. Legislación Atinente a la Niñez em la Americas. Bueno Aires: Edicones, 1994.

SOUSA, Sônia Maria Gomes. Adolescentes autores de atos infracionais: estudos psicossociais. Goiânia: Ed. Da PUC Goiás, 2013.

SOUSA, Sônia Maria Gomes; Peres, Vanuzza Leal Andrade. Famílias de camadas populares: um lugar legítimo para a educação/formação dos filhos. In: Revista o social em questão. Ano 06, n. 7 - 1/2002.

SOUZA, J. G. Ressocialização prisional: a contradição entre o discurso e a prática institucional. Dissertação (Graduação). Universidade Federal do Rio Grande do Sul. Instituto de Filosofia e Ciências Humanas. Curso de Ciências Sociais: Bacharelado. Repositório Digital. Rio Grande do Sul, 2009. Disponível em <http://hdl.handle.net/10183/19001>. Acesso em: 18 de jul. 2016.

SOUZA-LEITE, Célia Regina Vieira de. O adolescente e a escola: as vicissitudes de uma etapa. In.: DIAS, Tárcia Regina da Silveira; SCRIPTORI, Carmen Campoy. Sujeito e Educação: estudos em educação. Florianópolis: Insular, 2008. P. 63-84.

TEIXERA, Maria de Lourdes Trassi. As histórias de Ana e Ivan - boas experiências em liberdade assistida. Coleção dá pra resolver. São Paulo: 2003.

VERDUM, Priscila. Práticas Pedagógicas: o que é? O que envolve? Revista Educação por Escrito - PUCRS, v. 4, n.1, jul.2013.

VERONESE, Josiane Rose Petry. Os direitos da criança e do adolescente. São Paulo: LTr, 1999.

; CUSTÓDIO, André Viana. Direito da Criança e do Adolescente: Para Concurso de Juiz do Trabalho. São Paulo: Edipro Concursos, 2011.

VIENNE, Philippe. Socialização e ressocialização: as políticas da educação para as classes populares. In.: Análise Social. Vol XL (176), 2005, 633-649.

VOLPI, Mário. O adolescente e o ato infracional. 10. ed. São Paulo: Cortez, 2015.

O adolescente e o ato infracional. 9. ed. São Paulo: Cortez, 2011.

ZAGO, Nadir. A entrevista e seu processo de construção: reflexões com base na experiência prática de pesquisa. In: CARVALHO, Maria Pinto de; VILELA, Rita Amelia Teixeira (Orgs.). Itinerários de pesquisa: perspectivas qualitativas em sociologia da educação. Rio de Janeiro: DP\&A. p. 287-309

ZALUAR, Alba. Um debate disperso: violência e crime no Brasil da redemocratização. São Paulo Perspec. [online]. 1999, vol.13, n.3, pp.3-17. ISSN 01028839. Disponível em <http://dx.doi.org/10.1590/S0102-88391999000300002>. Acesso em: 20 de junho 2017. 
ZANELlA, M. N. Bases teóricas da socioeducação: análise das práticas de intervenção e metodologias de atendimento do adolescente em situação de conflito com a lei. Dissertação de Mestrado. Universidade Bandeirante de São Paulo-SP. 2011.

WAISELFSZ, Julio Jacobo. Mapa da Violência 2016 - homicídios por arma de fogo no Brasil. Rio de Janeiro, FLACSO/CEBELA, 2016. 


\section{APÊNDICE}

APÊNDICE A: Quadro cronológico das principais normativas sobre o atendimento socioeducativo

\begin{tabular}{|c|c|}
\hline \multirow[t]{2}{*}{1985} & $\begin{array}{l}\text { Regras Mínimas das Nações Unidas para a } \\
\text { Administração da Justiça de Menores - } \\
\text { Regras de Beijing. }\end{array}$ \\
\hline & $\begin{array}{l}\text { Resolução 40/33, de } 29 \text { de Novembro de } \\
1985 \text { - Assembleia Geral das Nações } \\
\text { Unidas. }\end{array}$ \\
\hline 1988 & $\begin{array}{l}\text { Constituição Federal da } \text { República } \\
\text { Federativa do Brasil de } 1988 .\end{array}$ \\
\hline \multirow[t]{5}{*}{1990} & $\begin{array}{l}\text { Lei Federal } n^{\circ} 8.069 \text {, de } 13 \text { de Junho de } \\
\text { 1990. Institui o Estatuto da Criança e do } \\
\text { Adolescente. }\end{array}$ \\
\hline & $\begin{array}{l}\text { Decreto n } 99.710 \text {, de } 21 \text { de Novembro de } \\
\text { 1990. Promulga a Convenção sobre os } \\
\text { Direitos da Criança }\end{array}$ \\
\hline & $\begin{array}{l}\text { Princípios } \text { Orientadores de Riad - } \\
\text { Princípios } \text { Orientadores das Nações } \\
\text { Unidas para a Prevenção da Delinquência } \\
\text { Juvenil. }\end{array}$ \\
\hline & $\begin{array}{l}\text { Resolução 45/112, de } 14 \text { de Dezembro de } \\
1990 \text { - Assembleia Geral das Nações } \\
\text { Unidas. }\end{array}$ \\
\hline & $\begin{array}{l}\text { Regras Mínimas das Nações Unidas para a } \\
\text { Proteção dos Jovens Privados de } \\
\text { Liberdade - Unicef. Adotadas pela } \\
\text { Assembleia Geral das Nações Unidas em } \\
14 \text { de dezembro de 1990, durante o Oitavo } \\
\text { Congresso das Nações Unidas sobre a } \\
\text { prevenção do delito e do tratamento do }\end{array}$ \\
\hline
\end{tabular}




\begin{tabular}{|c|c|}
\hline & adolescente em conflito com a lei. \\
\hline 1991 & $\begin{array}{l}\text { Lei Federal no 8.242, de } 12 \text { de Outubro de } \\
\text { 1991. Cria o Conselho Nacional dos } \\
\text { Direitos da Criança e do Adolescente } \\
\text { (Conanda). }\end{array}$ \\
\hline 1996 & $\begin{array}{l}\text { Lei n } 9.394 \text {, de } 20 \text { de dezembro de } 1996 . \\
\text { Lei de Diretrizes e Bases da Educação. }\end{array}$ \\
\hline 2004 & $\begin{array}{l}\text { Diretrizes Curriculares Nacionais para a } \\
\text { Educação das Relações ÉtnicoRaciais e } \\
\text { para o Ensino de História e Cultura Afro- } \\
\text { Brasileira e Africana. Parecer CNE/CP n. } \\
\text { 3, de } 10 \text { de março de } 2004 \text { e Resolução n. } \\
\text { 1, de } 17 \text { de junho de } 2004 \text {. }\end{array}$ \\
\hline \multirow[t]{4}{*}{2006} & $\begin{array}{l}\text { Plano Nacional de Educação em Direitos } \\
\text { Humanos. }\end{array}$ \\
\hline & $\begin{array}{l}\text { Resolução } \mathrm{n}^{\circ} 113 \text {, de } 19 \text { de abril de } 2006 \\
\text { (Conanda). Dispõe sobre os parâmetros } \\
\text { para a institucionalização e fortalecimento } \\
\text { do Sistema de Garantia dos Direitos da } \\
\text { Criança e do Adolescente. }\end{array}$ \\
\hline & $\begin{array}{l}\text { Decreto s/n, de } 13 \text { de julho de 2006. Cria } \\
\text { a Comissão Intersetorial de } \\
\text { Acompanhamento do Sistema Nacional de } \\
\text { Atendimento Socioeducativo. }\end{array}$ \\
\hline & $\begin{array}{l}\text { Resolução } \mathrm{n}^{\circ} 119 \text {, de } 11 \text { de dezembro de } \\
\text { 2006. Dispõe sobre o Sistema Nacional de } \\
\text { Atendimento Socioeducativo }\end{array}$ \\
\hline 2008 & $\begin{array}{l}\text { Portaria MDS No } 222 / 2008 \text { - Estabelece o } \\
\text { inicio da implementação do Serviço de } \\
\text { MSE em Meio Aberto no âmbito do } \\
\text { SUAS }\end{array}$ \\
\hline 2009 & $\begin{array}{l}\text { Resolução } n^{\circ} 109 \text { de } 11 \text { de Novembro de } \\
2009 \text { do Conselho Nacional de }\end{array}$ \\
\hline
\end{tabular}




\begin{tabular}{|c|c|}
\hline & $\begin{array}{l}\text { Assistência Social - CNAS. Dispõe sobre } \\
\text { a Tipificação Nacional de Serviços } \\
\text { Socioassistenciais. }\end{array}$ \\
\hline & $\begin{array}{l}\text { Programa Nacional de Direitos Humanos - } \\
\text { PNDH-3. Decreto } n^{\circ} 7.037 \text {, de } 21 \text { de } \\
\text { dezembro de } 2009 \text {. }\end{array}$ \\
\hline 2010 & $\begin{array}{l}\text { Diretrizes Nacionais para a Oferta de } \\
\text { Educação para Jovens e Adultos em } \\
\text { situação de privação de liberdade nos } \\
\text { estabelecimentos penais. Parecer } \\
\text { CNE/CEB no 4, de } 9 \text { de março de } 2010 \text { e } \\
\text { Resolução } n^{\circ} 2 \text {, de } 19 \text { de maio de } 2010 \text {. }\end{array}$ \\
\hline 2011 & $\begin{array}{l}\text { Plano Decenal dos Direitos Humanos de } \\
\text { Crianças e Adolescentes. Aprovado pelo } \\
\text { CONANDA no dia } 19 \text { de abril de } 2011 \text {. }\end{array}$ \\
\hline 2012 & $\begin{array}{l}\text { Lei }^{\circ} \text { 12.594, de } 18 \text { de janeiro de } 2012 . \\
\text { Institui o Sistema Nacional de } \\
\text { Atendimento Socioeducativo (Sinase). }\end{array}$ \\
\hline & $\begin{array}{l}\text { Portaria Interministerial } \mathrm{n}^{\circ} 990 \text {, de } 1^{\circ} \text { de } \\
\text { agosto de 2012. Institui Grupo de } \\
\text { Trabalho Interministerial (MEC e } \\
\text { SDH/PR) para elaborar propostas e } \\
\text { estratégias para a escolarização e } \\
\text { profissionalização de adolescentes que } \\
\text { cumprem medidas }\end{array}$ \\
\hline & $\begin{array}{l}\text { Carta de Constituição de Estratégias em } \\
\text { Defesa da Proteção Integral dos Direitos } \\
\text { da Criança e do Adolescente Publicada no } \\
\text { Diário da Justiça Eletrônico do Conselho } \\
\text { Nacional de Justiça, n }{ }^{\circ} 189 \text {, em } 15 \text { de } \\
\text { outubro de } 2012 \text {. }\end{array}$ \\
\hline & $\begin{array}{l}\text { Nota Técnica } \mathrm{n}^{\circ} 38 \text {, de } 26 \text { de agosto de } \\
2013\end{array}$ \\
\hline
\end{tabular}




\begin{tabular}{|l|l|}
\hline (CGDH/DPEDHUC/SECADI/MEC). \\
Traz orientação às Secretarias Estaduais \\
de Educação para a implementação da Lei \\
do Sinase.
\end{tabular}

